\title{
Gothic Imaginations in Primo Ottocento Opera
}

\author{
By Sarah Chesney
}

\begin{abstract}
A Thesis submitted to the New Zealand School of Music in fulfilment of the requirements for the degree of Master of Music in Musicology
\end{abstract}

New Zealand School of Music 


\begin{abstract}
Connections between the Gothic and opera remain a subsidiary concern to most writers on the Gothic and on opera, if they are even addressed at all. In this study I wish to illuminate how the Gothic is presented both musically and visually on stage through the setting and thematic traits in select nineteenth-century Italian operas. A number of ideas are central to this aim. Firstly, that the 'Gothic' dimension of 'Gothic opera' is overtly represented through staging. The settings of many 'Gothic operas' in Scotland and England reveal the continental European fascination with northern Europe and its history. This stemmed from the influx of English and Scottish literature, most prominently the Ossian poems and the works of Walter Scott and Shakespeare. Consequently, Gothic scenes such as ruined medieval castles and rugged cliffs, masked by darkness or mist are enmeshed with a northern landscape. Tartan costuming also visually situates the Gothic scenes in Northern Europe. Furthermore, the use of musical mannerisms of Scotland and England, particularly in chorus scenes, reinforces this parallel between the Gothic and the north, linking music to the visible Gothic setting. Secondly, I will explore the way in which Gothic imaginings of both immaterial and physical incarnations of the supernatural move between the latent subconscious and conscious realisation. This is evident through the interplay between voice, orchestra and the singer's corporeality and draws upon recent operatic studies concerning representation of 'others', dramatisation, and theatrical spaces. This second section positions women at the heart of the Gothic in opera, as the soprano is most often the character susceptible to other-worldly encounters and madness.
\end{abstract}


The fundamental figure in this study is Gaetano Donizetti (1797-1848). A number of his operas from the 1830s, especially Lucia di Lammermoor, emphasise how the Gothic may be revealed in opera. However, I conclude with a chapter on Macbeth, the 'Gothic opera' of Giuseppe Verdi (1813-1901), for this work demonstrates how the configuration of the Gothic is developed in musical and dramatic terms and presents a case where the supernatural influence becomes all-empowered. 


\section{Acknowledgements}

Firstly, I wish to thank my supervisors, Dr Inge van Rij and Prof. Elizabeth Hudson. Their discerning comments and many suggestions about my work have been invaluable. There are a number of other people who have assisted this project in various ways. I am grateful to my family, especially my parents, for proofreading, providing many cups of tea and an alternative place to work. Also, thanks go to Andrew for his help entering musical examples. I wish to show my appreciation to Dean, for giving me the time and space to complete my thesis; and to Connor, for his enthusiasm for opera in general and 'all those crazy ladies'. Thanks must also go to two of my friends and fellow Master's students in particular: Alex, for the many coffee dates, helpful suggestions and proofreading; and Teressa, for advice, proofreading, and sharing amusing eighteenthcentury quotations. 


\section{Contents}

Abstract................................................... $\quad i$

Acknowledgements.......................................... ii

List of Examples.......................................... $v$

List of Figures............................................ vii

Introduction............................................... 1

Chapter One: Scotland and the Gothic

Neapolitan Scotland...................................... $\quad 19$

The Myth of the North................................... 25

Scotland's Dual Personas................................... $\quad 33$

Donizetti and Cammarano's 'Scottish Opera'................. $\quad 39$

Musical 'Scottishness'.................................. $\quad 45$

The Visual Gothic....................................... 65

Chapter Two: 'Heroines', Hallucination, and Hysteria

Gothic Women......................................... 93

Emma et Lucie............................................ 109

Other Voices.......................................... 116

'L'ombra mostrarsi' ...................................... 122

'Quella voce m'é qui nel cor discesa'..................... 143

Chapter Three: The Witches' Lair

Verdi's Gothic Opera.................................. $\quad 162$

Grand Opera and Gothic Opera........................... 171

'Il sol cruento mio pensier la dà forma' ..................... 185

Conclusion.................................................. 233

Appendices:

Appendix 1: Timeline of significant translations and adaptations of the Ossian Poems.............. 237

$\begin{aligned} \text { Appendix 2: Timeline of significant translations and } & \\ & \text { adaptations of the literature of Walter Scott.... }\end{aligned}$

Appendix 3: Donizetti's Gothic and British Operas.......... 248

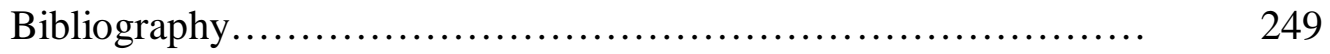




\section{List of Examples}

Example 1.1: Preludio from Donizetti's Lucia di Lammermoor, bb.1-21.

Example 1.2: Preludio from Donizetti's Lucrezia Borgia, bb.1-13. 48

Example 1.3: Hunting chorus from Act 1, scene 1 of Donizetti's Lucia di Lammermoor, bb. 64-90.

Example 1.4: 'Per te d'immenso giubilo' from Act 2, scene 2 in Donizetti's Lucia di Lammermoor, bb. 20-35.

Example 1.5: 'D'immeso giubilo', Act 3, scene 2 from Donizetti's Lucia di Lammermoor, bb. 34-74.

Example 1.6: Sinfonia from Donizetti's Roberto Devereux, bb. 10-29.

Example 1.7: Elisabetta's entrance for her cavatina in Act 1, scene 2 of Donizetti's Roberto Devereux, bb. 1-6.

Example 2.1: 'Home Sweet Home', from John Bishop's Clari. 97

Example 2.2: Act 2 finale of Donizetti's Anna Bolena, bb. 293-6.

Example 2.3: Act 2 finale of Donizetti's Anna Bolena, bb.160-8.

97

Example 2.4: 'Cielo a'miei lunghi spasimi', Act 2 finale of Donizetti's Anna Bolena, bb. 246-57.

Example 2.5: 'Coppia iniqua',Act 2 finale of Donizetti's Anna Bolena, bb. 361-88.

Example 2.6: Harp introduction to Lucia's cavatina, Act 1, scene 2 of Donizetti's Lucia di Lammermoor, bb. 1-8.

Example 2.7: Scena, Act 1,scene 2 of Donizetti's Lucia di Lammermoor, bb. 27-48.

Example 2.8: 'Regnava nel silenzio', Act 1, scene 2 of Donizetti's Lucia di Lammermoor, bb. 58-95.

Example 2.9: 'Quando rapito in estasti', Act 1, scene 2 of Lucia di Lammermoor, Donizetti, bb. 129-34.

Example 2.10: Act 2 finale of Lucia di Lammermoor, Donizetti, bb. 132-9.

Example 2.11: Raimondo's aria, Act 3, scene 2 of Donizetti's Lucia di Lammermoor, bb. 19-31.

Example 2.12: 'Ardon gl'incensi', Act 3, scene 2 of Donizetti's Lucia di Lammermoor, bb. 7-28.

Example 2.13: Act 3, scene 2 of Donizetti's Lucia di Lammermoor, bb. 78-94.

Example 2.14: Lucia's mad scene, Act 3, scene 2 of Donizetti's Lucia di Lammermoor, bb. 21-4.

Example 2.15: The return of 'Verranno a te' in the mad scene, Act 3, scene 2 of Donizetti's Lucia di Lammermoor, bb. 42-50. 
Example 2.16: 'Spargi d'amaro pianto', Act 3, scene 2 of Lucia di Lammermoor, Donizetti, bb. 270-95.

Example 3.1: Witches' chorus, Act 1, scene 1 of Verdi's Macbeth, bb. $52-7$.

Example 3.2: Drum interruption and Allegro of witches' chorus, Act 1, scene 1 of Verdi's Macbeth, bb. 90-120.

Example 3.3: Witches' Waltz, Act 3, scene 1 of Verdi's Macbeth, bb. 207-14.

Example 3.4: 'Tutto è finito' motive, Act 1, scene 4 of Verdi's Macbeth, bb. 76-99.

Example 3.5: 'Come del ciel' from Act 2, scene 2 of Verdi's Macbeth, bb. 21-9.

Example 3.6: Duet, Act 1, scene 4 of Verdi's Macbeth, bb. 136-94.

Example 3.7: 'Sappia la sposa mia', Act 1, scene 4 of Verdi's Macbeth, bb. 9-22.

Example 3.8: 'Sappia la sposa mia', Act 1, scene 4 of Verdi's Macbeth, bb. 52-6.

Example 3.9: Brindisi theme, Act 2 finale of Verdi's Macbeth, bb. $80-8$.

Example 3.10: Act 2 finale of Verdi's Macbeth, bb. 396-413.

Example 3.11: Lady Macbeth's sonnambulismo, Act 4, scene 2 of Verdi's Macbeth, bb. 1-78. 


\section{List of Figures}

Figure 1.1: 'Sala nel Castello di Windsor negli appartamenti delle regina', Alessandro Sanquirico, stage design for Act 1, scene 1 of Donizetti's Anna Bolena ( Milan, Teatre Carcano, 1830).

Figure 1.2: 'Parco nel Castello di Windsor', Alessandro Sanquirico, stage design for Act 1, scene 2 of Donizetti's Anna Bolena ( Milan, Teatre Carcano, 1830).

Figure 1.3: John Constable's Salisbury Cathedral from the Bishop's Garden, (1825).

Figure 1.4: 'Atrio delle prigioni nella Torre di Londra', Alessandro Sanquirico, stage design for Act 2, scene 3 of Donizetti's Anna Bolena ( Milan, Teatre Carcano, 1830). 71

Figure 1.5: Alessandro Sanquirico, costume for Anna in Donizetti's Anna Bolena ( Milan, Teatre Carcano, 1830).

Figure 1.6: Alessandro Sanquirico, costume for Percy in Donizetti's Anna Bolena ( Milan, Teatre Carcano, 1830).

Figure 1.7: Filippo Peroni, costume for Edgardo in Donizetti's Lucia di Lammermoor (Naples, Teatro san Carlo, 1835).

Figure 1.8: Filippo Peroni, costume for Enrico in Donizetti's Lucia di Lammermoor (Naples, Teatro san Carlo, 1835).

Figure 1.9: Fanny Tacchinardi-Persiani as Lucia at the London Premiere, Her Majesty's Theatre, 5 April 1838.

Figure 1.10: Filippo Peroni, costume for Alisa (left) and Lucia (right) in Donizetti's Lucia di Lammermoor (Naples, Teatro san Carlo, 1835).

Figure 1.11: Costume for Alisa in Donizetti's Lucia di Lammermoor (Paris, Théâtre-Italien, 1837).

Figure 1.12: Hautecouer Herménégilde, costume for Lucie in Act 3 of Donizetti's Lucie de Lammermoor (Paris, Théâtre de la Renaissance, 1839).

Figure 1.13: Hautecouer Herménégilde, costume for Lucie in Act 3 of Donizetti's Lucie de Lammermoor (Paris, Théâtre de la Renaissance, 1839).

Figure 1.14: Francesco Bagnara's set design for Act 3, scene 3 of Donizetti's Lucia di Lammermoor (Venice, Teatro la Fenice, 1844).

Figure 1.15: Francesco Bagnara's set design for Act 3, scene 3 of Donizetti's Lucia di Lammermoor (Venice, Teatro la Fenice, 1844). 
Figure 2.1: Joshua Reynold's portrait of the Countesse of Eglinton (1777). Photograph courtesy of Agnew's, London/The Bridgeman Art Library.

Figure 3.2: 'Parco. In lontananza il castello di Macbeth', Giuseppe Bertoja's stage design for Act 2, scene 2 of Verdi's Macbeth (Venice, Teatro La Fenice, 1847).

Figure 3.1: Giuseppe Bertoja's stage design for the witches' grotto in Act 1, scene 1 of Verdi's Macbeth (Venice, Teatro La Fenice, 1847).

Figure 3.3: Costume for Macbeth in Verdi's Macbeth (Venice, la Fenice, 1847).

Figure 3.4: Costume for Lady Macbeth in Act 4 of Verdi's Macbeth (Venice, la Fenice, 1847).

Figure 3.5: Costume for the witches in Verdi's Macbeth (Venice, Teatro la Fenice, 1847).

Figure 3.6: Henry Füssli's Three Witches (1783). Photograph courtesy of the Collection of the Royal Shakespeare Theatre/The Bridgeman Art Library. 


\section{Introduction}

Horace Walpole's Castle of Otranto is generally acknowledged as the first Gothic novel. The work instigated motives and plot scenarios that later became fundamental in classifying a work as Gothic, a genre that fast took hold of the reading public in late eighteenth-century Britain. The Gothic was not restricted to novels, finding a following among Romantic poets and dramatists well into the nineteenth century. Inspired by the architecture of the Gothic Revival, Walpole wrote in a genre closer to drama than literature. Marshall Brown states that:

There were no novels like Otranto. But Walpole's interests, plain as day, lay in the theatre. His novel is built on a dramatic plan, and its closest models numerous models - come from the early-eighteenth-century play-house. ${ }^{1}$

Walpole's descriptions convey a sense of theatrical direction and placement, emerging from his architectural stimuli. As Walpole writes in his third-person introduction to

\section{Otranto:}

The author [in fact, Walpole himself] seems frequently, without design, to describe particular parts. 'The chamber,' says he, 'on the right hand;' 'the door on the left hand;' 'the distance from the chapel to Conrad's apartment:' these and other passages are strong presumptions that the author had some certain building in his eye. ${ }^{2}$

The theatricality of the Gothic is also evident from the criticism aimed at Italian opera in the early eighteenth century. Anne Williams has indicated that in the eighteenth and nineteenth centuries, opera and Gothic novels were seen as similarly irrational and

\footnotetext{
${ }^{1}$ Marshall Brown, The Gothic Text, Stanford: Stanford University Press, 2005, p. xi.

${ }^{2}$ Horace Walpole, The Castle of Otranto, edited by Paul Negri, Mineola: Dover Publications, 1966, p. 19.
} 
unhealthy; both genres met with displeasure from middle-class men in particular. ${ }^{3}$ Herbert Lindenberger also remarks on a connection between Gothic fiction and opera, both of which are characterised by 'distance from the ordinary life, on the one hand, and, on the other, its power and immediacy of effect' ${ }^{4}$ Furthermore, both the Gothic and the operatic were perceived as extravagant, fantastic and unbelievable in the nineteenth century, a notion that arguably persists today. The popularity of the Gothic novel lasted well into the nineteenth century and beyond, yet 'Gothic' opera had a relatively short life span, and works employing the themes and setting of the Gothic visual arts or literature were not considered 'Gothic' in the nineteenth century. Indeed, the way in which the meaning of the term 'Gothic' has shifted over time and place is problematic and makes obtaining a single interpretation or definition almost impossible.

Connections between the Gothic and opera remain a subsidiary concern to most writers on the Gothic and on opera; many writers do not even address the Gothic at all. In nineteenth-century Italian operas, the Gothic is presented both musically and visually on stage through the setting and thematic traits. For even when a reviewer cites an opera as Gothic, there is little doubt that this term refers to the sets or the plot, rather than any notions of how the Gothic is illustrated within the score itself. As verismo and operatic realism gained strength in the later nineteenth century, the number of newly composed operas that could be classed as Gothic, or at least as retaining a Gothic flavour, dwindled. The appetite for the Gothic persisted though, as operas from the first half of the nineteenth century mostly remained popular during the latter half of the

\footnotetext{
${ }^{3}$ Anne Williams explains that Gothic novels were considered 'threatening to middle-class consumers of popular fiction' and especially for the morality of young women, who would often borrow Gothic fiction from circulating libraries. See Williams, 'Ghostly Voices: "Gothic Opera" and the Failure of Gounod's La Nonne Sanglante', pp. 125-6. David Maill also remarks that 'Gothic fiction led a curious borderline existence, widely read, but on the borders of both respectability and literariness'. It had a similar air of disrepute to the theatre or music hall and a melodramatic display of excess and irrationality to opera. David S. Miall, 'Gothic Fiction' in A companion to Romanticism, edited by Duncan Wu, Oxford and Malden: Blackwell Publishers, 1998, p. 346.

${ }^{4}$ Herbert Lindenberger, Opera, the Extravagant Art, Ithaca: Cornell University Press, 1984, p. 167.
} 
century. This is certainly true of one of the central works of this study, Lucia di Lammermoor, the 1835 dramma tragico by Gaetano Donizetti (1797-1848). The sense of dramatic power and 'otherness' Lindenberger uses to connect the Gothic and opera further helps to account for the appeal of Lucia, which was set in Scotland and based on Walter Scott's 1819 novel The Bride of Lammermoor. Donizetti clearly indicates his Romantic preferences when, after finishing Lucia, he rejected a libretto that did not meet his requirements. Writing to impresario Giuseppe Consul, he announces 'if I am not in complete sympathy with [the libretto] I shall send it back. I want love, violent love, without which these subjects are cold'.

The term 'Gothic' was first used derogatorily by educated sixteenth-century Italians to express their distaste for the prominent style of medieval architecture, which had originated in Northern France in the twelfth century. ${ }^{6}$ The style spread throughout Europe, with regional variations, over the following centuries and was subsequently associated with the Goths, the people who lived in the area encompassing modern Scandinavia, Denmark and Eastern Germany. In 1510 prominent Italian architect Donato Bramante tried to re-establish the 'superior' Classical style. He denounced the then prevalent architecture as Germanic, describing it as 'bizarre animals and figures and crude foliage, all unnatural and irrational. ${ }^{7}$ The painter Giorgio Vasari is credited with first use of 'Gothic' in this artistic context. Twenty years after Bramante's predominantly incorrect (but widely accepted) assumptions that German design caused

\footnotetext{
${ }^{5}$ William Ashbrook, Donizetti and his Operas, Cambridge: Cambridge University Press, 1982, p. 99.

${ }^{6}$ Peter Kidson, et al. 'Gothic' In Grove Art Online. Oxford Art Online, http://www.oxfordartonline.com/subscriber/article/grove/art/T033435pg6, (29 April 2009).

${ }^{7}$ Chris Brooks, The Gothic Revival, London: Phaidon, 1999, p. 9.
} 
the widespread rejection of Classical style, Vasari blamed the degeneration - as he saw it - in artistic style on the collapse of the Roman Empire under the Goths in the fifth century:

This manner of building was invented by the Goths, who put up structures in this way after all the ancient buildings had been destroyed and all the architects killed in the wars. It was they who made vaults with pointed arches... and then filled the whole of Italy with their accursed buildings. ${ }^{8}$

He neglected to acknowledge that French examples of what was now known as 'Gothic' style predate those in Germany (and also Britain) by half a century. In the same vein of thought, Peter Kidson notes that sixteenth-century Italians explained the development of the Gothic based on preconceived notions of Goths and the Germanic people more widely. They suggested that the pointed arch 'would come naturally to the minds of men whose original habitat had been the northern forests. ${ }^{9}$ The theory that Gothic architecture belonged to, or was at least characteristic of, the 'dark ages' persisted into the nineteenth century, notwithstanding the seven hundred year gap observed by late seventeenth-century historians between the fall of the Roman Empire and the first examples of 'Gothic' architecture in the twelfth century. This excludes the Goths as direct instigators of the style, yet the meaning of Gothic as something barbaric or uncouth of Germanic or Teutonic origins persisted. With the advent of the Gothic revival from the eighteenth century onwards, the unreason and primitivism associated with the Gothic style was no longer seen negatively. When Walpole subtitled Otranto a 'Gothic Story' it was this medieval setting he was alluding to. He set the narrative in a medieval-Gothic structure to establish essential themes of the Gothic novel, which in turn influenced other visual arts and music. As Gothic fiction grew alongside the interest in psychology and the subconscious of the late-eighteenth and nineteenth

\footnotetext{
${ }^{8}$ Ibid, p. 10.

${ }^{9}$ Peter Kidson et al, 'Gothic', In Grove Art Online. Oxford Art Online, http://www.oxfordartonline.com/subscriber/article/grove/art/T033435pg1, accessed February 12, 2009.
} 
centuries, the depths of dungeons and hidden passageways of Gothic buildings provided a metaphor for the unreason, delusion or insanity of its inhabitants in what David Miall describes as 'the architecture of the mind'. ${ }^{10}$ The subterranean passages of Gothic structures that conceal the body in Gothic literature - Walpole's Isabella is concealed underneath the church, for instance - also become figurative, as subterranean passages of the mind housing latent thoughts. Miall further notes that 'the appeal of Gothic architecture is to the sublime - to forces of vastness, power, obscurity and terror described in Edmund Burke's highly influential treatment of the sublime, $A$ Philosophical Enquiry', which was published seven years before Otranto. ${ }^{11}$

Architects of churches and cathedrals favoured the grandeur of Gothic designs, particularly the height and majesty of the style's defining pointed arch. The stonework and vaulted ceilings of the new Gothic buildings were simultaneously a practical solution to the fire danger of wooden structures and a technical necessity to accommodate the large windows that were more aesthetically suited to the religious purpose of most Gothic buildings, their elevated height appropriate for exaltation. ${ }^{12}$ Paradoxically, the literary Gothic motive of darkness seems to subvert the original architectural style's aims of lightness and illumination, both literally and figuratively. Large windows and open spaces were used to achieve this departure from the notoriously dark, lower and less elaborate Romanesque style, which most closely predates (and overlaps) the Gothic. ${ }^{13}$ In addition to practical and symbolic motivations of Gothic form, other such prominent features as flying buttresses, ribbed vaults and the overall asymmetry of the structure create an opposition to the 'ideal' Classical

\footnotetext{
${ }^{10}$ Miall, 'Gothic Fiction', p. 346.

${ }^{11}$ Ibid, p. 345.

${ }_{12}$ Michael Hall, Gothic Architecture and its Meanings 1550-1830, Reading: Spire books 2002, p. 18.

${ }^{13}$ Kidson, 'Gothic'.
} 
constructions. ${ }^{14}$ The distinctive features of these Gothic buildings are crucial to how scenery of an opera visually establishes the Gothic.

Therefore 'Gothic' is the term used to describe buildings constructed between the twelfth and sixteenth centuries, and structures built in later centuries which were modelled on medieval style. However, under the increasingly Romantic aesthetic predilections of the late eighteenth and early nineteenth centuries, the term extends to encompass abstract themes also.

$$
* * *
$$

The Gothic as understood today in the context of late-eighteenth and nineteenth-century art forms, is a construction of the Gothic revival, a movement that began in the mid eighteenth century in English literature and emerged from the Sturm und Drang movement in Germany as a counter-movement to Classicism and the Enlightenment. However, any definition of the Gothic is problematic. The Gothic has variously been called a 'genre', 'mode', 'mood', and 'myth'. ${ }^{15}$ While the Gothic relates to Romanticism, it also transcends any temporal boundaries placed on it, as the Gothic is a popular 'genre' in the arts today and has undergone many changes in form and focus since the eighteenth century.

\footnotetext{
${ }^{14}$ The use of orders and rounded 'triumphant' arches of strict proportions, form and symmetry befits the rationality and order valued by the Classicists.

${ }^{15}$ These different terms have been applied by many scholars writing on the Gothic. Among others, Susan Wolstenholme (in her Gothic (Re)visions: Writing Women as Readers, Albany: State University of New York Press, 1993) refers to the 'Gothic mode'; both 'Gothic mode' and 'Gothic genre' are terms employed by the contributors of The Cambridge Companion to Gothic Fiction (edited by Jerrold E. Hogel, Cambridge: Cambridge University Press, 2002); Clive Blooms uses 'Gothic mood' in Gothic Histories, A Taste for Terror, 1764 to the Present, New York: Continuum, 2010; and Eugenia DeLamotte refers to 'Gothic myths' in her study Perils of the Night, Oxford: Oxford University Press, 1990. I will term it a genre, with the understanding that, as with most other 'genres' it implies a set of formal and stylistic conventions, within which there are inevitable exceptions.
} 
In Victor Hugo's 'Preface' to Cromwell (1827) he describes how the grotesque

is essential to Romanticism using terms that relate just as easily to the Gothic: ${ }^{16}$

In the idea of men of modern times, however, the grotesque plays an enormous part. It is found everywhere; on the one hand it creates the abnormal and the horrible, on the other the comic and the burlesque. It fastens upon religion a thousand original superstitions, upon poetry a thousand picturesque fancies. It is the grotesque which scatters lavishly, in air, water, earth, fire, those myriads of intermediary creatures which we find all alive in the popular traditions of the Middle Ages; it is the grotesque which impels the ghastly antics of the witches' revels, which gives Satan his horns, his cloven foot and his bat's wings...We will simply say here that, as a means of contrast with the sublime, the grotesque is, in our view, the richest source that nature can offer art. ${ }^{17}$

Furthermore, Hugo traces the grotesque to Italy, explaining that it is from figures such as Dante and Homer - of both medieval and Classical eras - who first bring elements of the grotesque into art: ${ }^{18}$ 'We see it make its way from the South to the North. It disports itself in the dreams of the Teutonic nations, and at the same time vivifies with its breath the admirable Spanish romanceros'. ${ }^{19}$ For Hugo, the grotesque is apparent prior to any style of Gothic architecture, as the literary grotesque 'imposes its characteristic qualities upon that wonderful architecture which, in the Middle Ages, takes the place of all the arts'. $^{20}$ Thus Hugo complicates notions of Gothic origins due to how the grotesque and,

\footnotetext{
16 'Dans la pensée des modernes, au contrairie, le grotesque a un rôle immense. Il y est partout; d'une part, il crée le difforme et l'horrible; de l'autre le comique et le bouffon. Il attache autour de la religion mille superstitions originales, autour de la poésie mille imaginations pittoresques. C'est lui qui sème à pleines mains dans l'air, dans l'eau, dans la terre, dans le feu, ces myriades d'êtres intermédiaires que nous retrouvons tout vivants dans les traditions populaires du moyen âge; c'est lui qui fait tourner dans l'ombre la ronde effrayante du sabbat, lui encore qui donne à Satan les cornes, les pieds de bouc, les ailes de chauve-souris.' Victor Hugo, 'Preface' to Cromwell, in Théatre: Les trois premiers actes de Cromwell, Hetzel: Paris, 1858, p. 14.

${ }^{17}$ Victor Hugo, 'Preface' to Cromwell, in Prefaces and Prologues to Famous Books: Part 39, edited by Charles W. Eliot, translated by Andrew Motte, Harvard Classics, 1910, p. 365.

18 'On le voit s'étendre du sud au septentrion. Il se joue dans les rêves des nations tudesques, et en même temps vivifie de son souffle ces admirables romanceros espagnols.' Victor Hugo, 'Preface' to Cromwell, in Théatre: Les trois premiers actes de Cromwell, p. 17.

${ }^{19}$ Victor Hugo, 'Preface' to Cromwell, in Prefaces and Prologues to Famous Books, p. 368.

20 'il imprime surtout son caractère à cette merveilleuse architecture, qui, dans le moyen âge, tient la place de tous les arts.' Victor Hugo, 'Preface' to Cromwell, in Théatre: Les trois premiers actes de Cromwell, p. 17. Victor Hugo, 'Preface' to Cromwell, in Prefaces and Prologues to Famous Books, p. 368.
} 
with it the Gothic, are defined. However, it is the amalgamation of the ugly and the beautiful that he believes is most essential for drama: ${ }^{21}$

The fact is, then, that the grotesque is one of the supreme beauties of the drama. It is not simply an appropriate element of it, but is oftentimes a necessity...the drama is the grotesque in conjunction with the sublime, the soul within the body; it is tragedy beneath comedy...The romantic stage would make a piquant, savoury, diversified dish of that which, on the classic stage, is a drug divided into two pills. ${ }^{22}$

It is this emphasis placed on Gothic elements as part of Romanticism that makes it difficult to determine precisely where one stops and the other begins; although both can be seen to co-exist with overlapping boundaries, rather than being fully one and the same. For opera, this notion of the beautiful and the grotesque existing simultaneously and within each other can be seen in the musical portrayal of the Gothic text, which is sometimes incongruously cheerful for the sombre or macabre libretto and creates the uncanniness of the Gothic in opera.

$$
* * *
$$

In the early nineteenth century, the Gothic was bound up with the Italian perceptions of Romanticism, which were infiltrating the still largely Classically-minded region gradually from the 1810s. Britain, Germany and France all have a more perceptible Gothic tradition than Italy, which meant that in the primo ottocento, Italy was more closely tied to Classical style than its European neighbours. In 1816 Madame de Staël, a well-travelled salon owner and author living in Paris, encouraged Italian authors to translate French and German poetry and foreign dramas, including the works of William

\footnotetext{
21 'C'est donc une des suprêmes beautés du drame que le grotesque. Il n'en est pafi seulement une convenance, il en est souvent une nécessité...le drame, c'est le grotesque avec le sublime, l’âme sous le corps, c'est une tragédie sous une comédie...La scène romantique ferait un mets piquant, varié, savoureux, de ce qui sur le théâtre classique est une médecine divisée en deux pilules.' Victor Hugo, 'Preface' to Cromwell, in Théatre: Les trois premiers actes de Cromwell, pp. 23 and 45-6.

${ }^{22}$ Victor Hugo, 'Preface' to Cromwell, in Prefaces and Prologues to Famous Books, pp. 375 and 403-4.
} 
Shakespeare and Friedrich Schiller. This would present 'new genres and styles to Italian readers, who were otherwise too liable to think of nothing but outdated tales of ancient mythology'. ${ }^{23}$ Her comments highlighted the division between wider European Romantic trends of individual expression and the Classical models replicated in Italian art forms. Gary Tomlinson explains that earlier in 1816 (in Milan), literary Romanticists Ludovico di Breme, Pietro Borsieri, and Giovanni Berchet, self-published pamphlets 'that have come to be considered the chief manifestos of Italian Romanticism'. ${ }^{24}$ Consequently, Romanticism was in its literary infancy and Classical tastes predominated in Italy at this time. Those who were compelled towards Romanticism, such as Ermes Visconti, felt Classical works lacked the ability to powerfully affect their audiences, and that continuing ancient modes did not support the aspirations of many Italians for a national unity and identity, and towards modernisation. In contrast, Classicists wanted to retain the traditional influences that set their Italian style apart from their counterparts abroad, and distanced themselves from the essentially foreign Romantic trends. ${ }^{25}$

Gina Martegiani aroused much debate when she reiterated this view in her 1908 study, Il Romanticismo italiano non esiste, arguing that Italian Romanticism derived from the German philosophical thought of Schiller, Fichte and Kant, and Italian Romantics only desired to imitate foreigners, rather than forge their own absolute art forms. ${ }^{26}$ Her comment draws attention to the very Italian art form this thesis is concerned with: opera, and specifically Donizetti's impact on the genre. In 1826,

\footnotetext{
${ }^{23}$ Anna Luisa Staël-Holstein, Madame de Staël, 'Sulla maniera e la utilià delle traduzioni', Biblioteca italiana, January 1816, pp. 9-18 in Manifesti romantici e altri scritti della polemica classico-romantica, edited by Carlo Calcaterra, rev. and enlarged by Mario Scotti, Turin: 1975, pp. 83-92. Translated by Gary Tomlinson, 'Italian Romanticism and Italian Opera: An Essay in their Affinities', $19^{\text {th }}$-Century Music, Vol. 10, No. 1, Summer 1986, p. 43.

${ }^{24}$ Gary Tomlinson, 'Italian Romanticism and Italian Opera', p. 44.

25 Ibid, p. 45.

${ }^{26}$ Marteginani's “negative evaluation” is explained by Joseph Luzzi. 'Did Italian Romanticism Exist?', Comparative Literature, Vol. 56, No. 2, Spring 2004, p. 170.
} 
Donizetti composed his first Gothic opera, Gabriella di Vergy, which, as Melina Esse indicates, was unusual as it was written purely for his own pleasure, rather than as part of a contract with a theatre. ${ }^{27}$ This early opera shows Donizetti was concerned with Gothic - and thereby Romantic - subjects. His drive for dramatic power debunks the general consensus, expressed even amongst Italians themselves, that opera was merely a fatuous entertainment. ${ }^{28}$ In the 1820s and 1830s, Donizetti (and Vincenzo Bellini) were approaching Romantic expression in their melodie lunghe and increased dramatic impetus. They were also setting texts based on Scottish, English and French literature or historical events that either are Gothic, or contain a significant Gothic episode. ${ }^{29}$ The first translations of Shakespeare's and Schiller's dramas and the works of Sir Walter Scott appeared in the first decades of the nineteenth century, soon after Madame de Staël's critical observations. Scott's novels and poetry became hugely popular throughout continental Europe, and were beginning to be translated into Italian from 1821, a number of years after appearing in French and German. ${ }^{30}$ Scott is usually credited as the founder of the historical novel, and the influence of this genre on Alessandro Manzoni’s I promessi sposi is well documented. ${ }^{31}$ However, Manzoni’s novel sits on a Classical-Romantic divide, and there is nothing in the work that would imply the Gothic in Scott's novels influenced Manzoni. Instead, it was in music that Scott's Gothic scenarios were most evident, beginning with Rossini's La donna del lago in 1819.

\footnotetext{
${ }^{27}$ Melina Esse, 'Donizetti's Gothic Resurrections', Nineteenth-Century Music, Vol. 33, No. 2, (Fall 2009), p. 85.

${ }^{28}$ Tomlinson, 'Italian Romanticism and Italian Opera', p. 46.

${ }^{29}$ Gary Tomlinson explains that in the early 1820 s, Rossini was unconcerned with the controversial opinions of both the Classicists and Romantics, despite his likely awareness of the issues and the occurrence of Classical and, (especially in his later years) Romantic features in his works. See Ibid, pp. 47-9.

${ }^{30}$ Sir Walter Scott's Bride of Lammermoor (1819) was translated as La Promessa Sposa di Lammermoor by Gaetano Barbieri in 1823. There were a number of different translations of The Lady of the Lake, and Kenilworth published in 1821, which are the first dated examples of Italian translations of Scott's work.

${ }^{31}$ Manzoni's novel was written between 1821-7, first published in 1827 , with a revised edition in 1842)
} 
In 1835, Giuseppe Mazzini, a key instigator of the Risorgimento, labelled Donizetti as the "dawning Romantic" in his Filosofia della musica. ${ }^{32}$ In Mazzini's comparison of operatic composers, he regarded Rossini as a Classicist and described Donizetti as a musical pacesetter:

We might perhaps find one among the living who is worthy to found an ItalicoEuropean school of music, and become the regenerator, as he is the leader, of the Rossinian-Italian school. I allude to Donizetti, the only one amongst us whose eminently progressive character and talent displays regenerative tendency; the only one upon whom a heart that is wearied and disgusted by the servile crowd of imitators swarming over Italy can repose with a certain amount of hope. ${ }^{33}$

Mazzini believed that Donizetti was capable of leading Italy musically into a new era, but was disappointed this did not eventuate. ${ }^{34}$ When Mazzini revised his Filosofia for republication in his complete works, he excised almost the entire section on Donizetti from it, instead preferring to focus on the new progressor, saviour and true Romantic of Italian music: Giuseppe Verdi. Ironically, however, many of Verdi’s dramatic tendencies and his emphasis on the psychological elements of his characters had actually evolved from Donizetti's earlier treatments of extreme disturbances of mind and other-worldly intrusions. Verdi's development of Donizetti's representations of a Gothic mood in opera will be discussed in chapter three, outlining a shift between Lucia di Lammermoor and Macbeth.

The Risorgimento, the period leading up to Italian unification in 1860, had an enormous impact on Italian Romanticism. This endeavour to build to a new Western European power, politically and artistically, was driven by Mazzini, along with the other two Italian figureheads of the period, Camillo Benso, Count of Cavour and Giuseppe Garibaldi. Mazzini’s goals were to unite the Italian peninsula as the single

\footnotetext{
${ }^{32}$ Mazzini devoted none of his text to Bellini however, dismissing Donizetti's contemporary in a single footnote.

${ }^{33}$ Giuseppe Mazzini. Filosofia Della Musica. Translated by Emilie Venturi and edited by Franco Sciannameo. New York: Edwin Mellen Press, 2004, p. 58.

${ }^{34}$ Mazzini was concerned about how music interacts with social concerns, as a vehicle for social understanding and change, and was against music solely as entertainment.
} 
country of Italy, liberated from the foreign powers the country depended on economically and politically. Paradoxically, Italian Romanticists saw the adoption of the philosophies and dramatic artistic aims of France, Germany and Great Britain as the means of achieving this liberation, for it offered new possibilities for a progression from tired Classical ideas.

\section{$* * *$}

Gothic tropes vary widely, but a number of themes are ubiquitous within the genre.

Settings in literature, visual arts and opera are usually geographically, temporally and culturally 'other' for the intended audience. The intrusion of supernatural beings or occurrences is a vital component of the Gothic which covers an array of non-human disturbances; characters hallucinate and 'see' ghosts, either 'real' or imagined and in Lucia di Lammermoor and Macbeth the other-worldly beings are demonic. There is a strong presence of psychological or physical mysteries, secrets and hidden identities in the Gothic - often inextricable from the plot lines following ancient family ties, curses or violent crimes. Gothic novels often end with proclaiming the true heir, outing a family secret or decoding a mysterious feud or crime. Gothic women are typically victimised and oppressed, frequently driven mad by the patriarchal society they exist in. There are few women with any authority, as mothers are conventionally absent.

These themes are often discussed in studies of particular works, yet seldom defined as Gothic in the context of opera studies. ${ }^{35}$ Indeed, Gothic opera also evades

\footnotetext{
${ }^{35}$ Studies of operatic madness and the role of women in bel canto opera use the term rarely, however, Stephen Willier uses the influence of the Gothic to construct a study of Bellini's Il pirata, and Anne Williams notes that Lucia is possibly the only canonical Gothic opera. In Willier's earlier dissertation, Early Nineteenth-Century Opera and the Impact of the Gothic, he devotes a large proportion of his paper to plot synopses of Gothic novels and the ways in which the opera(s) based on them diverge from this. This too, is the purpose of Jerome Mitchell's The Walter Scott Operas. Neither study is limited to Italian
} 
easy definition. Unlike literature of the late eighteenth century and beyond, where describing a work as 'Gothic' meant, at least in part, pertaining to a set of conventions of plot, character, and setting, 'Gothic opera' cannot stand apart from the tragic or grand opera in which these literary influences were embedded. Although similar scenarios and characters present in Gothic literature also appear in opera, this does not automatically render the work Gothic, as what can be considered 'Gothic' about opera is also intrinsically operatic; many Gothic themes were already common operatic themes, offering crucial drama for serious or tragic opera. In the Romantic period, Gothic scenarios and characters so haunted poetry, drama and the development of the novel as to become conventional. Yet in opera, many of these same elements had been stock for the librettist and opera composer for decades. The major difference was that now the insane demise of the heroine or her disguise as a long lost sister or queen were not comic jests, designed to invite laughter from the audience at a character's naivety or lack of farsightedness. The tragedy of Gothic plots was permeating opera and, with the gradual loosening of censorship rules in many Italian centres, particularly Milan and Naples, tragic opera became commonplace. As we have seen, the term 'Gothic' in its earliest meaning to Italians implies an influence from beyond both geographical and temporal borders. In the Gothic revival of the nineteenth century an obsession with 'otherness' and portraying foreign settings, characters and eras is a defining quality of Gothic literature, and for opera. Furthermore, both the Gothic and the operatic were perceived as extravagant, fantastic, and unbelievable in the nineteenth century, a notion that arguably persists today. Gothic themes were already common 'operatic' themes,

opera, nor, surprisingly, do the musical and visual elements of opera play a major part. See Jerome Mitchell, The Walter Scott Operas, Tuscaloosa: University of Alabama Press, 1977; Stephen A. Willier, Early Nineteenth-Century Opera and the Impact of the Gothic, Ph D., University of Illinois, 1987; 'Madness, the Gothic, and Bellini's Il pirata', The Opera Quartley, Vol. 6, No. 4, Summer 1989; Anne Williams, 'Ghostly voices: "Gothic opera" and failure of Gounod's La nonne sanglante'. In Operatic migrations: Transforming works and crossing boundaries, edited by Roberta Montemorre Marvin and Downing A. Thomas. Aldershot: Ashgate, 2006, p. 127. 
and they offered crucial drama and plot for serious or tragic opera (and in the case of mistaken or undisclosed identity, also for comic opera).

While Italian composers situated their Gothic plots in Northern Europe, Walpole (and later Ann Radcliffe, among others) spin their tales before an Italian backdrop. This geographical shift could suggest that the immediate locale of the ancient castle, ruined manor house or dark forest is perhaps more central than whether a work is set in northern or southern Europe. The scenarios are constructed as indicative of an outside culture, one inclined to uncouthness or barbarity. Brown explains that approaches to critical studies of the Gothic have been based on social influences; they 'examine gender and politics, domesticity and tyranny, reception and influences (from science in particular). All are studies in encounter, ${ }^{36}$ By contrast, Brown wishes to read Gothic novels as 'daydreamy recreations to immerse oneself in privately... as serious enquiries into and models of the mind' ${ }^{37}$ He takes his direction from the coinciding popularity of Immanuel Kant and Otranto in the 1780s (a decidedly social beginning), with the notion that 'Kant and the Gothic together discovered a new dimension of human consciousness'. ${ }^{38}$ Brown's assertion that the Gothic can be an exploration of the mind parallels the operatic studies by Carolyn Abbate and Gary Tomlinson, whose work provides a framework for exploring transcendence between visible and immaterial spheres in later chapters. Both these musicologists' discussions hinge on terms from Kant - noumenal and phenomenal - which are used to express the changes in a character's awareness of their operatic sound world and the transcendence of voice between material and metaphysical realms. Therefore, the way in which characters

\footnotetext{
${ }^{36}$ Brown, The Gothic Text, p. xi. Anne Williams also asserts that the Gothic is defined by its 'other' and by what it isn't, rather than by what it is. Anne Williams, Art of Darkness: A Poetics of Gothic, Chicago: Chicago University Press, 1995, p. 19.

${ }^{37}$ Brown, The Gothic Text, p. xi.

${ }^{38}$ Ibid, p. ix.
} 
react with the other-worldly, metaphysical and supernatural is central to a study on opera and on the Gothic, as will be explored in chapters two and three.

While this approach to the Gothic as a condition of human consciousness is compelling, it is impossible to deny weight to those other approaches to the Gothic that Brown departs from. Most writers on the Gothic do in fact recognise the genre's faculty for transcendental or exteroceptive and interoceptive enquiries. Psychoanalytical approaches to the Gothic are further evidence of a focus on the subconscious that creates associations (or disjunctions) between action, location, and innermost thought. Furthermore, the Gothic is as obsessed with fleshy forms as opera is. The Gothic can be physically violent, bloodthirsty, and focused on the motions and parts of the human body - breathing, hand-wringing or wailing - that react to sensations of horror or terror.

Much of this physical element of the Gothic is propelled by a focus on Gothic women. The shifting ideologies about female madness were fundamental in audience perceptions of operatic mad women in the nineteenth century. Elaine Showalter and Mary Ann Smart discuss the notion that in the nineteenth century madness was associated with the feminine, 'a manifestation of the mystery and the threat of female sexuality'. ${ }^{39}$ Moreover, Showalter also observes that madness was no longer considered monstrous and instead madwomen were treated as ill and vulnerable, requiring careful nurturing to restore their sanity. ${ }^{40}$ There were a number of culturally constructed madwomen, one of whom was the violent knife-wielding Lucia. The other two were Shakespeare's suicidal Ophelia from Hamlet and the Gothic novelist Matthew Lewis's 'sentimental' 'Crazy Jane'. ${ }^{41}$ Showalter explains that artists' impressions of madwomen

\footnotetext{
${ }^{39}$ Mary Ann Smart, 'The Silencing of Lucia', Cambridge Opera Journal, Vol. 4, No. 2 (July, 1992), pp. 121.

${ }^{40}$ Elaine Showalter, The Female Malady: Women, Madness, and Female Culture 1830-1980, London: Virago, 1987, p. 8.

${ }^{41}$ Ibid, p. 10.
} 
in the 1820s portrays that 'even when they are described as manic, these women have sweet smiles and pretty features; they are shown in elaborate caps and bonnets, like the millinery models in the ladies' annuals' ${ }^{42}$ This juxtaposition between disturbed states of mind and 'sweetness' is seen in Gothic opera, although not visually, as most operatic madwomen wander the stage in a white gown. Even if their gown is not splattered with blood, there is some association of brutality in their appearance. However, this 'sweetness' can be discerned in the music, as the tragic final aria of the heroine is set to pleasant music. These disjunctions between music and plot appear to heighten the representation of hysteria - the women are without inhibition or understanding of their plight. The musical 'sweetness' creates a chilling sense of the Gothic through the horrifying appearance of the soprano on stage, and their uncannily cheerful voice.

At around the same time that feminist criticism was beginning in opera studies, the female role in the Gothic was being considered in more detail. In Art of Darkness: A Poetics of Gothic, Anne Williams not only considers the role of women in Gothic plots but also separates the Gothic into 'two traditions', the 'male and female formulas'. ${ }^{43}$ She summarises her argument by listing the contrasting attributes associated with the male and female sides, built around the patriarchal familial structure inherent to the Gothic and opera. The female tradition of the Gothic, according to Williams, links terms of subordination and oppression. For example, the female is 'signified' and 'unconscious', rather than the male role as 'signifier' and 'conscious'. ${ }^{4}$ While her paradigms are adequate for the poetic modes of Williams's study, the male and female roles in opera sometimes invert her distinctions. The voice given to women in opera is fundamental and sets the operatic Gothic apart from the Gothic of other

\footnotetext{
${ }^{42}$ Ibid, p. 14.

${ }^{43}$ Anne Williams, Art of Darkness, p. 99.

44 Ibid.
} 
artistic genres. Thus women in opera are usually not 'signified' in the same manner as their literary counterparts, nor are they restricted to text rather than speech. As the operatic studies of Catherine Clément, Susan McClary and Smart show, the operatic heroine can gain empowerment through voice. This will be considered further in chapter two. However, Williams's distinction between the conscious and the unconscious is a concurrent theme in opera. As she and other feminist scholars writing on the Gothic have outlined, the psychological limits of women are not fixed or definable as they are for men; instead they are penetrable and 'problematic' ${ }^{45}$ These unbounded conditions of the female imagination are apparent in operas when the soprano has an other-worldly encounter or descends into insanity. However, the view that madness is foremost a feminine condition appears to gloss over the, often less famous, instances of male madness that do occur in literature and in opera.

Additionally, Williams's expression of a male and female Gothic division rests on a number of other factors, including a separation between the formulations of the supernatural. ${ }^{46}$ A work conforming to the male Gothic would assume that the reader (or watcher, presumably) lays aside his or her own sense of reason before entering the fictional world. It is assumed that the supernatural is 'real' and inexplicable, whereas in the female Gothic, all supernatural occurrences are explained as being caused by the supernatural powers of the imagination. ${ }^{47}$ While Gothic opera does not fit into Williams's formulaic criteria per se, it does highlight an affinity between the enquiries into the Gothic and opera. The problematic nature of operatic supernaturalism arises from changes in characters' awareness of their musical environment, between what is

\footnotetext{
${ }^{45}$ Ibid, p. 100.

${ }^{46}$ The plot of the male Gothic is tragic, as opposed to the happy outcome required under a female set of conventions. A male Gothic work also narrated from multiple perspectives, rather than a central (female character). However, neither of these concepts is especially weighty when translated to opera, for it is inherent in a genre where characters literally speak, that the plot has multiple narrators. See Williams, Art of Darkness, p. 101-2.

${ }^{47}$ Ibid, p. 103.
} 
'real' and 'abstract' and who can see and/or hear what. The confinement of opera heroines within male-determined operatic structures is something I will return to, but it is significant that the women are subject to 'male' structural constraints and counteract this through less defined psychological boundaries. Even if the Gothic treatment of women does not always map easily onto opera, and vice versa, in both the Gothic and in opera, women play an essential and intriguingly complex role in their Gothic settings. 


\title{
Chapter One: Scotland and the Gothic
}

\author{
Neapolitan Scotland
}

The initial reception of Lucia di Lammermoor, after its premiere at the Teatro San Carlo in 1835 was overwhelmingly positive. ${ }^{1}$ The production ran to twenty-two performances and in its first eighteen months was presented in five other Italian centres. In 1837, the work opened in Paris, where it had a successful run at the Théâtre-Italien. The opera's Parisian début was followed by a French adaptation of the work in 1839 by Alphonse Royer and Gustave Vaëz, in consultation with Donizetti, for the Théâtre de la Renaissance. The opera was a hit, capitalising on the immensely popular reign Scott's novels were enjoying in Paris. Among Donizetti's works, Lucia boasts unrivalled and enduring success, not falling out of favour even when it seemed the shine of Gothic scenarios had worn off later in the nineteenth century.

Despite Lucia's success, especially in later years, William Ashbrook shows that and Donizetti and his librettist Salvadore Cammarano's next opera, Belisario, was initially even more popular than Lucia. $^{2}$ Nonetheless, after the first two years, the number of Lucia productions surpassed those of Belisario, which Ashbrook concludes is most likely due to Belisario's Classical subject and the absence of a love story. ${ }^{3}$ The audience is not invited to be sympathetic towards Antonia, the opera's malicious

\footnotetext{
${ }^{1}$ William Ashbrook, Donizetti and his Operas, Cambridge: Cambridge University Press, 1982, p. 98. ${ }^{2}$ Belisario opened in February 1836.

${ }^{3}$ In the first two years Lucia was performed 17 times, while 37 performances of Belisario were given. William Ashbrook, 'Popular Success, the Critics and Fame: The Early Careers of Lucia di Lammermoor and Belisario', Cambridge Opera Journal, Vol. 2, No. 1, March 1990, pp. 74 and 77-81.
} 
heroine, as they are towards Lucia. That Lucia's popularity relies on its subject and the strength of the musical drama is a logical assumption considering the many different casts that performed the work. Although Fanny Tacchinardi-Persiani's Lucia would surely have propelled it initially, the work was not performed by a stellar cast in many of the smaller towns it opened in.

In Naples, the premiere of Lucia was much anticipated. The sublime inspiration of Donizetti, the marvellous singing of Persiani and Dupez and the thunderous applause for the composer and principals dominated the discussions afterwards. ${ }^{4}$ Donizetti wrote to Giovanni Ricordi:

Lucia di Lammermoor has been performed, and kindly permit me to shame myself and tell you the truth. It has pleased me very much, if I can believe the applause and the compliments I have received. I was called out many times, and a great many times the singers, too. The king's brother Leopoldo, who was present and applauded, paid me the most flattering compliments...Every number was listened to in religious silence and spontaneously hailed with shouts of Evviva!...La Tacchinardi, Duprez, Cosselli and Porto have carried themselves very well, especially the first two, who are marvellous. ${ }^{5}$

Even outside of the tightly controlled Italian media industry, reviews of the premiere focus on the singers' success. A case in point is the one fragment mentioned in the 'Foreign Musical Report' of the British journal The Musical Library after the first English performance in London on 5 April, 1838, with Persiani and Rubini in the roles of Lucia and Edgardo: 'The composer, and the three principal performers, Mad.

Tacchinardi, Duprey [sic] (tenor), and Cosselli (base) [sic], were called for till they were weary'. ${ }^{6}$ However, in general the reviews of the London premiere were not especially favourable. In the Literary Gazette, which had an extensive readership, the anonymous reviewer says of the 'over-lauded' opera:

\footnotetext{
${ }^{4}$ Annalisa Bini and Jeremy Commons, Le prima reppresentatazioni delle opere di Donizetti nella stampa coeva, Milan: Skira, 1997, pp. 524-31.

${ }_{5}^{5}$ Ashbrook, Donizetti and his Operas, p. 98.

${ }^{6}$ (Anonymous reviewer), The Musical Library, edited by Charles Knight, London, November 1835, p. 48.
} 
The music of the opera is generally thin and uninteresting: occasionally a sweet musical passage arouses attention: but ere applause has time to follow the sweet sounds have passed to return no more. ${ }^{7}$

The reviewer of The Athenaeum, also writing two days after the premiere, echoes this

view and laments the outcome of the novel-to-opera transformation:

Lucia was received far more coolly here than was the case in Paris. While in the libretto, the original story has suffered great dilution - a weaker musical composition would be impossible to imagine. With the best will to remember and admire, we cannot recall one fresh note or combination. There is a concerted piece in the finale to the second act, which has a sweet and flowing melody; and Rubini's last air is worked up by him into a marvel of expression...in the course of a metamorphosis of a Waverley novel to a peg for Donizetti's insipid music, Sir William Ashton has disappeared, together with his lady-wife, besides other characters who chequer so impressively the web of the original story. ${ }^{8}$

For all its alleged insipidness, Lucia must have proved successful in ticket sales, as it became a mainstay on the British stage (and on the continent) for much of the nineteenth century. Italian reviews make no mention of the Scottish setting or musical depictions of the country. Certainly in England, where the initial attraction to Scotch songs can be partly attributed to the genre's contrast with the 'high' Italian operatic style, any noticeable 'Scottishness' does not warrant a mention in reviews of the London premiere. ${ }^{9}$ Moreover, to an audience outside Italy, features that may have sounded Scottish (or pan-British) to Italians would not necessarily have the same aural association to an English audience. The Athenaeum review is among a number that refer to the opera's source; it is probable the audience was familiar with Scott's novel and knew from their copies of the printed libretto and the costuming that the location of

\footnotetext{
${ }^{7}$ The Literary Gazette and Journal of the Belles Lettres, Arts, Sciences, \&c., edited by William Jerdan, London, 7 April 1838, No. 1107, p. 219, column 2-3.

${ }^{8}$ The Athenaeum: Journal of English and Foreign Literature, Science, and the Fine Arts, edited by Charles Wentworth Dike, London, 7 April 1838, No. 545, p. 259, column 3. I would suggest that the 'sweet and flowing melody' is probably the moderato of the quartet between Lucia, Edgardo, Enrico and Raimondo, which returns briefly before the stretta.

${ }^{9}$ Matthew Gelbart, The Invention of 'Folk Music' and 'Art Music': Emerging Categories from Ossian to Wagner, Cambridge: Cambridge University Press, 2007, p. 32.
} 
the drama was Scotland. Thus aware of the music's Scottish context, even if audiences in nineteenth-century London or elsewhere heard allusions of 'Scottishness' in Donizetti's score, they may have expected it and felt mentioning it unnecessary, as many operas of the period paint their music with couleur locale to indicate the opera's setting.

The nature of the intrinsic components of 'Scottish' music was widely discussed long before Donizetti's 'Scottish opera'. In his Traditional and National Music of Scotland, Francis Collinson describes the most tangible phrases used in Scottish music. Collinson details more musical symbols of 'Scottishness' than other authors on the subject, whose focus often only extends as far as tonal matters and the presence of Scotch snaps, notwithstanding modern scholars' realisation that these elements were not actually characteristic: ${ }^{10}$

the 'clichés' and 'mannerism[s]' (such as 'snap rhythms' and 'the habit of slipping down a whole tone for the second line of a tune') that were disproportionately represented in collections of real and purported Scottish tunes for the parlor and that, consequently, were adapted by composers when writing in supposedly Scottish manner. ${ }^{11}$

For exploring how a nineteenth-century composer such as Donizetti may have employed Scottish 'mannerisms', Collinson's description, outlining what seems to have been a general consensus about what 'Scottishness' sounded like, is worth considering. Collinson purports that dotted (snap) rhythms; melodic sequencing; four or eight bar phrasing; common or cut time metres; pentatonicism and hexatonicism; ending a piece outside the tonic key; and an abundance of grace notes, all connote 'Scottishness'. Due

\footnotetext{
${ }^{10}$ In his Scotland in Music, Roger Fiske says 'much of the attraction [of Scotch tunes] lies in the off-key ending'. He mentions the many examples he found of sources he would have expected to sound 'Scottish' that do not, or else they do not live up to the expectations that historical writing on Scottish music would have people believe. See Roger Fiske, Scotland in Music: A European Enthusiasm, Cambridge: Cambridge University Press, 1983, p. 3.

${ }^{11}$ Raymond Monelle, 'Scottish Music, Real and Spurious' in Music and Nationalism in $20^{\text {th }}$-Century Great Britain and Finland, Hamburg: Van Bockel, 1997, pp. 89-90, quoted in Locke, Musical Exoticism, p. 32.
} 
to the fact these musical features are common enough in Italian music, even numbers such as the Act 2 and 3 choruses of Lucia; 'Per te d'immenso giubilo' and 'D'immenso giubilo s'innalzi un grido' respectively, may not immediately stand out as Scottish for an audience without the accompanying visuals. The costumes and any dance movements enacted by the chorus are needed to cement the number as Scottish.

Further problematising the issue of specific Scottish local colour, Annalisa Bini and Jeremy Commons explain that it is rumoured 'Verrano a te sull' aure', the final part of Lucia and Edgardo's Act 1 duet, is based on a melody Donizetti had heard played on the cornmuse of rural Abruzzi. Even if this is hearsay, the opening phrase is identical to I sospiri, an arietta pastorale by Donizetti's contemporary, Nicola Vaccai. ${ }^{12}$ It is impossible to ascertain which piece came first, Donizetti's or Vaccai's, and it is plausible that the latter may have based his melody on the operatic tune - the title expresses the same sentiment of the duet (ardent sighing). It is also feasible, however, that both composers may have picked up on a folk tune, which could explain why foreign audiences attending the opera felt it was a musical illustration of Italy and any amount of Scottish couleur locale is mostly concealed within the Italian operatic conventions. Additionally, it is difficult to distinguish one of the most overt example of 'Scottishness', the Scotch snap, from Donizetti's Italian musical traditions; the stile Lombardo would have been familiar to Donizetti, a Lombardy native. It shares the rhythmical 'snap' with Scottish tunes and was a strong feature of Italian Baroque music. Yet examples of the stile Lombardo are usually in triple time, as opposed to the duplemetre snaps. The stile Lombardo predates the 'snap', which was not evident in Scotch songs before the eighteenth century. Indeed, because Purcell and other English composers employed the Scotch snap rhythm earlier to fit the stress patterns of the

\footnotetext{
${ }^{12}$ Bini and Commons, Le Prime Representazione delle opere di Donizetti, p. 522.
} 
English language - a type of musical iambic pentameter - the 'Scottishness' of the snap appears to have been appropriated by the Scotch song genre, rather than being 'historically Scottish'. Furthermore, English composers were influenced by continental styles such as the stile Lombardo and the French notes inégales.

Praising the music and performance of Lucia di Lammermoor after its premiere at the Théâtre-Italien, Astolfo, Marquis de Custine, wrote to Donizetti on 18 December 1837:

Your music gives me a sickness for your country, which is not mine...I constantly hope to find the means of coming there to see you and to breathe your sweet Neapolitan air and listen to your songs, which are so well in harmony with the nature that surrounds you. ${ }^{13}$

The Marquis de Custine's comment, while perhaps illuminating the parallels between the Italian and Scottish folk music, clearly highlights the subjectivity of musical interpretation. The Frenchman's reaction to music appended to a Scottish milieu demonstrates that foreign musical idioms and instances of couleur locale were not always conspicuous. Nonetheless, his pleasure in the 'Neapolitan air' still connotes the folk or regional accent heard in the music. The titles of Arcadian-sounding music included terms such as 'siciliana', along with 'pastoral' and 'musette', the former two stretching another tie between the Scottish and Italian musical languages. Even if he does not align the music with Scotland, the Marquis de Custine certainly felt the music was able to transport him. His comment is all the more interesting when paired with the theatre's décor. The costumes for the Théâtre-Italien were also unmistakably Scottish. Alisa is particularly eye-catching, wearing four different tartans (see figure 1.10, p. 82). If the Marquis's view is indicative of general audience perceptions, it shows the great extent to which any examples of Scottish (or 'northern') couleur locale in Donizetti's

\footnotetext{
${ }^{13}$ Herbert Weinstock, Donizetti and the World of Opera in Italy, Paris and Vienna in the First Half of the Nineteenth Century, London: Methuen, 1963, p. 132.
} 
Lucia and his other British operas are rooted in Italian folk and operatic musical styles indeed it could be argued they were the height of Italian opera practice.

The Myth of the North

An interest in Scotland developed in continental Europe after the publication of the poems of Robert Burns and especially the Ossian poems in the late eighteenth century. The Ossian poems are supposedly a group of pre-Christian era heroic tales allegedly collected and translated by James Macpherson in his 1760 Fragments of Ancient Poetry. These, along with the later Fingal (1762), Temora (1763), and The Works of Ossian (1765) were successful throughout Europe and North America. ${ }^{14}$ Ossian came into vogue in Italy with the translation of the Fingal (in versi sciolti) by Melchiorre Cesarotti in 1763, three years after Ossian extracts were translated and published in France (see appendix 1). ${ }^{15}$ The poems' stylistic imitation of Homer, Milton and the King James Bible caused Samuel Johnson, among others, to question the extent of Macpherson's adaptation and creation - and thereby their authenticity. Despite this, Cesarotti championed Macpherson's work. He was in little doubt over the poems' historical authenticity. Cesarotti went so far as to write Macpherson a congratulatory letter, to which the poet replied and sent copies of his work to Cesarotti in Venice, also vowing to send 'any further clarification [of authenticity] he might require'. ${ }^{16}$ Nine years after

\footnotetext{
${ }^{14}$ James Macpherson, Fragments of Ancient Poetry: Collected from the Highlands of Scotland and Translated from the Gaelic or Erse Language, Edinburgh: Hamilton and Balfour, 1760; James Macpherson, Fingal, an ancient epic poem in six books together with several other poems composed by Ossian, the son of Fingal, London: Beckett and de Hondt, 1762; James Macpherson, Temora, an ancient epic poem in eight books: together with several other poems, composed by Ossian, the son of Fingal, London: Beckett and de Hondt, 1763; The Works of Ossian, the Son of Fingal, Translated from the Gaelic Language, Paris: Jean-François Valade, 1765.

${ }^{15}$ Enrico Mattioda, 'Ossian in Italy: From Cesarotti to the Theatre', in The Reception of Ossian in Europe, edited by Howard Gaskell, London: Thoemmes Continuum, 2004, p. 274.

${ }^{16}$ Ibid, p. 279.
} 
translating Fingal, Cesarotti published the translated Ossian poems in a four-volume complete edition and subsequently issued what he considered a definitive edition in 1801. ${ }^{17}$

Cesarotti's translations were the catalyst for the large number of literary works and dramas based on Ossian. Furthermore, as there were no translations in Italy apart from Cesarotti's, there was nothing to compare directly with his versification and translation choices. ${ }^{18}$ In fact, Saverio Mattei, a music enthusiast and fellow scholar of Ancient Greek gave Cesarotti notes on the translations that maintained they were dramatically inadequate for opera libretti. Mattei's reasoning for this assumption was based on his own bias towards Metastasio's melodramatic techniques which distinguished recitative and aria by using different forms of versification: 'La Comala sarebbe più bella se avesse uno stile più metastasiano. I reciativi poco si distinguono dalle arie, e par ache via sia una confusione'. ['Comala would be much more beautiful if it were more Metastasian in style. The recitative parts are hardly distinguishable from the arias, and this seems to create some confusion'. $]^{19}$ Mattei appears to have overlooked the fact that most librettists were capable of adapting a work to suit their own purposes, and this is precisely what was done for most of the earliest Ossianic operas, as typical operatic plots of ill-fated love and concealed facts or identities were overlaid onto the Scottish backdrop.

The ripples of Ossian's influence continued to be felt in music generally - and in the Italian theatre in particular, throughout the nineteenth century. Dramatic genres plays, operas and ballets - felt the effects of Ossian longer than literature, possibly

\footnotetext{
${ }^{17}$ This last edition was part of a complete works edition which ran to forty volumes and also included Cesarotti's translations of Classical literature and his philosophical texts; Ibid, p. 287.

${ }^{18}$ Cesarotti wrote an accompanying preface and included notes and comments about his translation decisions, which was revised with an essay on authenticity for the 1801 edition of Poesie d'Ossian.

${ }^{19}$ Mattioda, 'Ossian in Italy: From Cesarotti to the Theatre', pp. 290-4.
} 
because it is doubtful that Ossian was ever performed in its original language in Italy, and for staged works it was more acceptable to modify the verse forms when necessary. The focus was instead on the general tone of the poems, as the plot lines are thin, relying predominantly on a repeated cycle of battles ending in heroic death. This is not to say that the poetic forms of Ossian were insignificant: Ossian's versification and imitation of Classical style were the lynchpins of the authenticity debate. Rather, after the initial Ossianic craze and the outing of the poems as a hoax, heroic poetic imitations of the Ossian poems gradually decreased. Yet even after the works were uncovered as entirely fabricated by Macpherson, they nonetheless influenced the literature of Scott, and Goethe, as well as the musical works of Mendelssohn, Schubert, Brahms, and Bizet. $^{20}$ Within Scotland's borders, the authenticity of the poems was hotly debated, particularly in relation to the associations the work brought to Scotland.

The Ossian poems permeated European consciousness and filtered into perceptions of Scotland outside of their musical settings. When planning his Macbeth, Verdi was well aware of the popular associations with Scotland due to the Ossian poems - and this was not how he envisaged the world of Macbeth. In his letter to Tito Ricordi, Verdi requests that Ricordi 'do me the favour of letting Perrone [sic] know that the period of Macbeth is much later than Ossian and the Roman Empire. Macbeth assassinated Duncan in 1040; and then he was killed in 1057...Don't fail to give Perrone this information immediately, because I believe he's mistaken about the period'. ${ }^{21}$

\footnotetext{
${ }^{20}$ See James Porter, 'Ossian' in Grove Music Online, Oxford Music Online, http://www.oxfordmusiconline.com/subscriber/article/grove/music/47070, (19 May 2009).

${ }^{21}$ Filipo Peroni was the set designer of Macbeth in 1847. David Rosen and Andrew Porter, Verdi's Macbeth: A Sourcebook, Cambridge: Cambridge University Press, 1984, p. 32-33; William Shakespeare, Macbeth, in The Oxford Shakespeare: The Complete Works (2ed.), edited by Gary Taylor and Stanley Wells, Oxford: Oxford University Press, 2005, p. 969.
} 
The other major figure to elevate Scotland in the minds of continental Europeans was Walter Scott. In the early nineteenth century, Italy lagged behind its neighbours in welcoming translations of foreign literature, including Scott's works, which accounts for Madame de Staël's criticism of the Italians' persisting Classicist aesthetics (see appendix 2). Northern European countries were the quickest to critique and translate Scott's works, particularly those with which the Gothic is most strongly associated. ${ }^{22}$ While the earliest translation appears to have been of two tales from Minstrelsy of the Scottish Border into German in 1810, extracts of his poetry in their original English were included in anthologies in Denmark and Sweden soon after Scott published them. $^{23}$ Translations published in Germany and Austria were the most numerous until 1813, and Beethoven's 1815 settings of Scott predate any Italian musical adaptations. As Matthew Gelbart convincingly suggests, the countries that were most quickly fascinated by folk idioms, of which Scottish music was seen as a prime example, were those without a long concept of a national art music tradition. Germany's musical hegemony was beginning around the middle of the nineteenth century and the discovery of folk and Scotland was significant in defining the differences between 'folk' and 'art' music and whether style can be national or universal. ${ }^{24}$

Early Italian musical settings, including Rossini's were fundamental in introducing Scott's work to a broader audience and attest to his influence on music predating his influence on literature. ${ }^{25}$ The ensuing translations of Scott's texts then sparked a craze for setting both his poetry and novels to music in France and Italy in the

\footnotetext{
${ }^{22}$ Certainly Italians were much slower to translate Scott than Cesarotti had been to translate the Ossian poems, although there were subsequently more translations made of Scott's works than the Ossian poems. ${ }^{23}$ The first reviews of his Minstrelsy of the Scottish Border, Lay of the Last Minstrel and The Lady of the Lake were most likely to have been written about the original English versions, as Scott wrote the first two volumes of this in 1802 and the third volume in 1803.

${ }^{24}$ Gelbart, 'Folk Music' and 'Art Music', pp. 229-30 and 236-8.

${ }^{25}$ Ossian was still being adapted for the Italian opera stage through the early decades of the nineteenthcentury.
} 
1820s and 1830s. It was not until 1821 that Barbieri's Italian translation of The Lady of the Lake appeared as La dama del lago, followed closely by a translation of Kenilworth in the same year. Rossini's 1819 opera La donna del lago premiered at the Teatro San Carlo in Naples two years earlier. Andrea Tottola, Rossini's librettist, would therefore have written his version based on either a French translation, or the English original. ${ }^{26}$ Four years earlier, Rossini had also composed an historical opera based on Elizabeth I, a full six years before Scott published Kenilworth, one of the texts that would subsequently motivate Donizetti to take up the same Tudor subject matter numerous times. To put this in a broader context, this was prior to the Spanish, Portuguese, Polish, Russian and Dutch translations that appeared in the next two years, but there had been no prior criticism based on Scott's works in Italy before translations were published, as there had been elsewhere, including in countries yet to publish Scott in their native language. Over the next decade, the majority of Scott's novels, and all his poetry, were published in translations (of hugely varying quality) in a number of Italian cities, and particularly Milan and Naples, two of the most renowned operatic centres. Although translations into French, German, and Italian occurred relatively closely together, operatic settings did not ensue so quickly outside Italy. Instead, literary imitation of Scott was rife. Sarah Hibberd notes the astonishing extent of Scott's impact, both in original form and in translation in Europe: 'it has been claimed that one third of all novels published in France in 1830 were works by Scott or translations of them - and a further substantial amount by his French imitators'. ${ }^{27}$ His enormous influence is further seen in the number of musical works based on Scott's literature,

\footnotetext{
${ }^{26}$ Richard Osborne, 'La Donna del lago', in The New Grove Dictionary of Opera, Oxford Music Online, http://www.oxfordmusiconline.com/subscriber/article/grove/music/O004007, (25 April 2009).

${ }^{27}$ Sarah Hibberd, French Grand Opera and the Historical Imagination, Cambridge: Cambridge University Press, 2009, pp. 21-2.
} 
which are second only to works based on Shakespeare. Hibberd has remarked on Scott's role in inciting a craze for historical settings:

The catalyst for this fascination with bringing the past alive, casting written history as drama, was Walter Scott...Scott's popularity derived essentially from his dynamic stylistic approach to the past; from his democratic casts; and from the topical resonance of his subject matter. In part taking their cue from Scott, liberal historians learned to express historical truth as a lively culmination of individual viewpoints. ${ }^{28}$

Scott's works contributed to promoting British history more generally. This trend towards historical operas was certainly visible in France and in Italy as tragic scenarios became increasingly popular. Setting an opera in the past (or a foreign country) was also a way to appease censorship regulations. In addition, Scott's emphasis on multiple viewpoints was an ideal attribute for operatic reworking. Perhaps it partly explains the popularity and frequent success that adaptations of his works for the theatre achieved. Unlike the typical Gothic novel, told by a single character or narrator, Scott often uses historical background to explain the reasons for a character's opinions. This serves as great fodder for the librettist but, conversely, means that enormous amounts of the original are cut or rehashed for the stage, as is true of Cammarano's adaptation of Lucia di Lammermoor.

Although many Italians (and other continental Europeans) were fascinated by Scott's literature, none of the Italian composers who wrote Scottish-inspired operas ever set foot in Scotland. This group includes virtually all the major contributors to the nineteenth-century operatic canon - Rossini, Bellini, Donizetti and Verdi, who instead represent the staging and 'Scottish' musical idioms based on inspiration garnered closer to home. Personal experience of the unknown lands many operas were set in was by no means essential for these operatic composers, who were part of the vast majority of Italians, and composers, who had never travelled to Scotland. Felix Mendelssohn was

${ }^{28}$ Ibid, p. 14. 
one of the few who did venture across to Britain, undertaking a walking tour of Scotland in 1829. He absorbed both landscape and folk music on his pilgrimage to the land that inspired the Ossian poems, the literature of Scott, Shakespeare, and European imaginations.

Mendelssohn's voyage to Scotland is well documented through his sketchbooks and letters. Mendelssohn's 'Scottish' compositions have encouraged a connection between the country and the composer in the minds of later authors and composers writing about him and his music. ${ }^{29}$ On 31 July, before setting off for the Highlands, Mendelssohn and his companion, Karl Klingemann, made an expedition south from Edinburgh toward the border with the specific intention of visiting Scott's home, Abbotsford. ${ }^{30}$ Mendelssohn thereby becomes the only notable composer inspired by Scott to have met him in his homeland. ${ }^{31}$ Mendelssohn and Klingemann's encounter with Scott, however, disappointed them greatly. Klingemann, after writing of an imaginary chance meeting with the author at a local inn, adds a postscript to his writing explaining the true circumstances:

We found Sir Walter in the act of leaving Abbotsford, stared at him like fools, drove eighty miles and lost a day for the sake of at best one half-hour of superficial conversation. Melrose [the nearby town] compensated us but little: we were out of humour with great men, with ourselves, with the world, with everything. It was a bad day. ${ }^{32}$

That Klingemann constructed an imaginary encounter at all is testament to Scott's celebrity and the extent of his inspiration. Mendelssohn and Klingemann were not to

\footnotetext{
${ }^{29}$ In Anthony Burgess's Mozart and the Wolfgang, the fictionalised Mendelssohn implies there will be detrimental consequences for anyone found renovating his 'person patch of infinity', which Burgess's Beethoven complains is too Scottish - 'Balmoral Castle, or somewhere with Fingal's cave outside the window'. See Anthony Burgess, Mozart and the Wolfgang, London: Vintage, 1991, pp. 3-4.

${ }^{30}$ R. Larry Todd, Mendelssohn: A Life in Music, Oxford: Oxford University Press, 2003, p. 214.

${ }^{31}$ Ibid, p. 214. Chopin also travelled to Scotland for three months (August to October) in 1848. Despite his admiration of the country, he was also dying of tuberculosis and composed no music there. See Fiske, Scotland in Music, pp. 149-155.

32 David Jenkins and Mark Visocchi, Mendelssohn in Scotland, London: Chappell and Company, 1978, pp. 57-9.
} 
know, however, that in 1825 Scott had expressed his aversion to visitors, 'especially foreigners'. ${ }^{33}$ Four years later, and in the wake of Scott's financial ruin, it is improbable that his attitude towards his sightseers had improved. Judging by what Scott wrote in his journal, Mendelssohn and Klingemann may well have been two of the sort of visitors least desired:

I do not like them. I hate fine waistcoats and breast-pins on dirty shirts. I detest the imprudence that pays a stranger compliments and harangues about his works in the author's house, which is usually ill-breeding. Moreover, they are seldom long of making it evident that they know nothing about what they are talking of, excepting having seen The Lady of the Lake at the opera. ${ }^{34}$

While the two travellers were likely well versed in Scott's literary works and even if they were well presented, Scott may not have given them much of a chance to prove his assumptions about foreigners otherwise. ${ }^{35}$ From Klingemann's dispirited reflection on the visit it is likely that Scott gave Mendelssohn and Klingemann the cold shoulder that most of his 'fans' that sought him out received. ${ }^{36}$ When Scott refers to 'The Lady of the Lake at the opera', he likely indicates Rossini's La donna del lago, which is the only significant operatic rendition of the poem. ${ }^{37}$ Thus this passage from Scott's diary furthermore highlights the role of musical adaptations in the reception of Scott's poetry and novels.

\footnotetext{
${ }^{33}$ On 23 November, 1825; Walter Scott, The Journal of Sir Walter Scott, edited by John Guthrie Tait, Edinburgh: Oliver and Boyd, 1950, p. 11.

34 Ibid.

${ }^{35}$ Scott was a favourite author of Mendelssohn's mother, Lea, and Mendelssohn family's library contained a number of his works. Klingemann claimed to have read all of Scott, when he was trying to impress an English woman who claimed to have read all of Kant (who Klingemann had not read). Although he may not have read all of Scott, he undoubtedly had read some. See Fiske, Scotland in Music, p. 120.

${ }^{36}$ However, Scott's aversion to foreigners certainly seems only to have extended to those who sought him out. He asked the pianist and composer Ignaz Moscheles and his wife, Charlotte, to Edinburgh for breakfast, and saw them again in social settings. See Roger Fiske, Scotland in Music: A European Enthusiasm, Cambridge: Cambridge University Press, 1983, pp. 117-8.

37 Jerome Mitchell explains that the Englishman Thomas Dibdin adapted The Lady of the Lake into a 'play interspersed with several musical numbers in 1810 and a 'musical drama' The Knight of Snowdoun, by Thomas Morton (text) and Henry Bishop (music) premiered in 1811. In the late 1820's Tottola's libretto for Rossini was set by Johann Vesque von Püttlingen (also known as Johann Hoven) and performed unstaged, but the score is lost. See Jerome Mitchell, The Wlter Scott Operas, Tuscaloosa: University of Alabama Press, 1977, p. 10.
} 


\section{Scotland's Dual Personas}

The dramatisation of Ossian already brings something of the Gothic to the stage. The poems abound with supernatural experiences of ghosts and visions, and the natural extremities of the Scottish setting. These associations of other-worldliness and sublime nature construct a Gothic, or 'anti-pastoral' side to the Scottish - and more specifically Highland - landscape and culture. The enormous popularity of Ossian in the second half of the eighteenth and nineteenth centuries leads Jeremy Day-O'Connell to describe the difference in Scottish musical idioms as 'the dark Gothicism of Ossian' and 'the more popular and cheerful Scottish style' conveyed in Scottish and English-composed 'Scotch' tunes. ${ }^{38}$ With the advance of Romanticism, this darker Scottish character emerged more strongly as it became a defining feature of mysterious and dark atmospheric music written by such continental composers as Mendelssohn and Berlioz to evoke Scotland.

The two distinct 'Scotlands' conveyed by (and for) outsiders in the lateeighteenth and early-nineteenth centuries affirm that Scottish music or, more precisely the texts of Scottish music, pertained to either the pastoral or Gothic modes. Although this dichotomy is certainly present before the eighteenth century, its continuation seems to have been fuelled by the Ossian myth.

There is a striking resemblance between late-eighteenth and nineteenth-century views of Scotland and the perceptions of the Alps. In his Landscape and Gender in Italian Opera, Emanuele Senici describes an ambivalent view of the Alps, somewhere between the sublime and the idyllic. At the same time as Ossian-mania was sweeping Europe, the historical symbolism of the Alps was changing. The centrality of the Alps

\footnotetext{
${ }^{38}$ Day-O'Connell, Pentatonicism, p. 88, based on John Daverio's 'Schumann's Ossianic Manner', $19^{\text {th }}$ Century Music, Vol, 21, No. 3 (1998), p. 253.
} 
in late-eighteenth-century writings triggered deeper and wider associations with the region than shown by earlier perceptions of the Alpine landscape as remote, rugged, dangerous, and uninhabitable except by savages; thus the descriptions convey a lucid homogeneity to Scotland and its people. The Alps, as figures of spectacular and unfathomable nature, are fundamental to philosophy on the sublime by Burke, Kant, and Schiller, who were most interested in the insight into human experiences that the Alps provide and the contrast between reason and feeling. ${ }^{39}$ As Senici explains, it seems travellers (often Englishmen on their Alpine tours) cemented the Alpine topos, which became a combination of two contradictory notions. In addition to the wild, uncouth and beastly side, the Alps represented an Arcadia; the region was pure, peaceful and graciously simple. The prevalent yet contradictory images the landscapes provoke show how Scotland and the Alpine region share a number of qualities. Both are also situated in equally remote regions: Scotland is on the northern margins of Europe and the Alps present forbidding and inaccessible mountainous terrain. The operatic reconstitution of Alpine landscapes also bears a number of parallels to the way in which Donizetti represents Scotland.

Senici’s examination of Bellini's La Sonnambula conveys this similarity between musical treatments of the two regions, and how remote or unfamiliar locations were responded to in more general musical terms within Italian operatic conventions. Like earlier operas with an pastoral or countryside Alpine setting, including Rossini's ranz des vaches-saturated Guillaume Tell, La sonnambula does not end tragically. However, much of Senici's discussion highlights parallels within issues of setting that are relevant to the Gothic tragedy. According to him, in Italian opera the voice of nature must be envoiced by the characters, chiefly women or, more specifically, virgins

\footnotetext{
${ }^{39}$ Emanuele Senici, Landscape and Gender in Italian Opera: The Alpine Virgin from Bellini to Puccini, Cambridge: Cambridge University Press, 2005, p. 23-4.
} 
who live within, or as part of, the landscape and thus invoke their surroundings through their own music. ${ }^{40}$ He explains that insinuating the operatic milieu in the introduction was typical of primo ottocento opera. ${ }^{41}$ Consequently, this is also where any local ambience frequently ends, aside from 'choral interventions' and dance tunes. ${ }^{42}$ Therefore Italian opera conventionally lacks a 'geographical specificity' and the landscape itself possesses a hardly discernible 'individual voice' within the music. ${ }^{43}$

In La sonnambula, Senici illustrates that French composers (and composers writing to appeal to French audiences) often conveyed the setting more forcefully than in operas composed for Italian audiences. ${ }^{44}$ Rossini’s Guillaume Tell was written for Paris, and in Eliza, Luigi Cherubini used incessantly repeated motives and the full strength of the orchestra to depict the almost violent grandeur and sublimity of the Alps (especially when Florindo is saved from his suicide attempt by an avalanche). ${ }^{45}$ Italian composers' Alpine representations are more subdued in comparison. Senici explains that Giovanni Simone Mayr's Elisa includes rustic drones and horn calls, while echo effects convey a sense of the landscape's vastness. ${ }^{46}$ Bellini's Alpine landscape in $\mathrm{La}$ sonnambula is even more subtle than Mayr's. He connects the pure landscape to Amina's own virginal purity through her music (with a few echo effects). Amina's cavatina fits precisely into solita forma; regular four-bar phrasing and Bellini's signature 'melodie lunghe' smoothly traverse the breadth of her vocal range to portray her synthesis within her natural surroundings. ${ }^{47}$

\footnotetext{
${ }^{40}$ Ibid, p. 19.

${ }^{41}$ Ibid, p. 42.

42 Ibid, p. 35

43 Ibid, pp. 53-4.

${ }^{44}$ La Sonnambula was one of a number of operas and ballets drawn from Victor Ducange's successful 1820 mélodrame, Thérèse ou l'Orpheline de Genève.

${ }^{45}$ Senici, Landscape and Gender in Italian Opera, p. 38.

${ }^{46}$ Ibid, pp. 41-2.

${ }^{47}$ Ibid, pp. 58-61.
} 
Donizetti's depiction of Scotland, while not as subtle as Bellini's Alpine setting, is still solidly within Italian operatic conventions - although Senici notes that Bellini tends towards less overt audible representations of setting than most composers. ${ }^{48}$ Lucia's cavatina denotes her placement within a Scottish-Gothic setting in much the same way as Amina is at one with her own landscape. Lucia's estrangement from her surroundings through her interiority as she relives her hallucination by the fountain, in turn positions her within a Gothic setting by envoicing her landscape and the Gothic intrusion, a notion that will be discussed in further detail below.

The descriptions of Scotland by Anne MacVicar Grant, often referred to as Anne of Laggan in the nineteenth century, in her Essays on the Superstitions of the Highlanders of Scotland, convey similar contrasts to those presented in discourses of Alpine landscapes and cultures - the noble savage in a setting of lofty simplicity versus the barbarous and crude inhabitant of a harsh landscape. Grant portrays 'savage' Scotland as a place where 'the tangled luxuriancy [sic] of the thorny wild would obstruct our path; and from the gloom of the impenetrable thicket, the lurking tiger, or the envenomed serpent would seem ready to spring; and at least haunt the startled imagination. ${ }^{49}$ Her writings Romanticise the harsh Scottish terrain. They simultaneously imply the idyllic and allude to a darker side of 'haunting' and the unenlightened past, and bear a closer resemblance to works of her continental and south-of-the-border contemporaries - including Mendelssohn and Klingemann - than might be expected from a native Scotswoman. Nonetheless, this distinction is also perceptible in Scott's literature where he separates the Highlands and Lowlands, and treats the Gothic as a kind of Highland folk tradition of Scotland.

\footnotetext{
${ }^{48}$ Ibid, p. 54.

49 Anne MacVicar Grant, Essays on the Superstitions of the Highlanders of Scotland: to which are added, translations from the Gaelic; and letters connected with those formerly published in two volumes by the author of "Letters from the Mountains." London: Longman et al, 1811, pp. 2-3.
} 
In eighteenth and nineteenth-century Scotland, there was a division between Lowlanders and Highlanders. The Gaelic-speaking Highlands, still socially organised by clan alliances and seen as barbaric and primitive by the Lowlanders, were, as Matthew Gelbart outlines in his Invention of "Folk Music" and "Art Music", 'impenetrable both linguistically and geographically'. 50 The Lowlanders looked upon the Highlanders in much the same way as northern Italians viewed their southern neighbours in the eighteenth and nineteenth centuries, as 'backwards' and primitive, their agricultural society bereft of progress or improvement. ${ }^{51}$ According to Grant, the Highlanders' 'enthusiasm' for the supernatural separated them from the more 'enlightened' Lowlanders. ${ }^{52}$ Grant explains that the Reformation brought greater practising of religion to the Highlands, 'among even the lowest class of believers' and that visions, ghosts and other supernatural 'imaginings' were seen as 'visitings of Satan' and thereby justified within a religious framework, which the Lowlanders considered an irrational doctrinal error. ${ }^{53}$

While the Lowlanders wished to detach themselves from the Highlanders, the English made little differentiation between the regions. The 'Scottishness' observed by the English (and all those outside the county) therefore typified only Highlanders, but was used as a blanket association for all of Scotland, despite the Lowlanders' attempts to align themselves against this by assimilating English and European traditions, culture, and popular tastes. This 'Englishness' of the Lowlands, where people would have heard much the same music as those living in England, is perhaps another reason

\footnotetext{
${ }^{50}$ Gelbart, The Invention of "Folk Music" and "Art Music", p. 29.

${ }^{51}$ Lucy Riall, The Italian Risorgimento: State, Society, and National Unification, London and New York: Routledge, 1994, pp. 49-51.

${ }_{53}$ Grant, Essays on the Superstitions of the Highlanders of Scotland, p. 136.

${ }^{53}$ Ibid, p. 134.
} 
why Scotch songs initially lack distinctly 'Scottish' musical symbols and rely on the text, often conveying a 'rude sweetness', to place it within the genre. ${ }^{54}$

The notion that there are multiple, simultaneous depictions of Scotland has been explored in detail by Gelbart. While he does not mention the Gothic, Gelbart's discussion of the pastoral qualities of the poetry and music of Scotch songs directs the music that falls outside a pastoral category towards the Gothic, for example in songs that include a supernatural episode or consider the Scottish landscape or culture, to be shrouded in darkness. These two moods can be figured as two sides of the same coin, bridged by the keyword of 'nature', either as wild or idyllic. As part of a Gothic mode, wild nature suggests a power or fury, and while it does not necessarily extend to reflecting the Scottish people, this association with Scotland still works in opposition to the pastoral and reflects back upon the visual staging of operas. Part of this ambiguous view of Scotland and 'Scottish' music rested on the fact that many of the earliest 'Scotch tunes' were not written in Scotland, but were composed by Englishmen and appeared in English books of popular music. Therefore, the so-called 'Scotch' or 'English' songs were a construction of the country, rather than a model of 'traditional' music of the region, from their inception in the seventeenth century. ${ }^{55}$ For Europeans outside Britain (and even within it), there was little difference between most Scottish and English music - a claim that is justified by inspecting collections such as John Playford's The English Dancing Master, which was published in many editions between 1651 and 1728 and includes a great variety of pieces.

Ideas of Scottish nationalism rose from the merging of England and Scotland under the Act of Union in 1707. As the eighteenth century progressed, musical representation of Scotland came increasingly from the publication of Scotch songbooks

\footnotetext{
${ }^{54}$ Gelbart, The Invention of "Folk Music" and "Art Music", p. 28.

${ }^{55}$ Ibid, p. 28.
} 
from within Scotland, which depicted it as pastoral and Arcadian, a picturesque and unspoiled landscape, primitive in only the most positive sense - as a nostalgic idealisation of Scotland in an earlier time - before merging with England. In England, 'Scottish' music went in and out of fashion in the eighteenth century. As more songbooks were published, Scotch songs were paired with English ones and any exotic allure wore off in favour of musical styles from the continent, particularly Italian Opera. Outside Scotland, though, the attraction of Scottish songs was partially based on illustrating distant nations or folk origins and composers latched on to particular musical traits, as Collinson describes, to construct a Scottish atmosphere.

\section{Donizetti and Cammarano's 'Scottish Opera'}

It is unlikely that Donizetti would have been able to distinguish between the Highlands and Lowlands from Scott's novel The Bride of Lammermoor. The tale is set in the Lowlands, but embodies much of the dark Gothicism connected with the Highland landscape. Therefore any differentiation between Scotland's two musical personas is confounded in the opera. Although Donizetti was one of many composers to find inspiration in Scott, his Lucia di Lammermoor has outlasted other operas. ${ }^{56}$ Other settings of Scott appear to have fallen out of favour after their premieres and were never revived. Rossini's Donna del Lago is not a mainstay on opera stages today, but was

\footnotetext{
${ }^{56}$ Michele Carafa's Le Nozze di Lammermoor (with a libretto by Giuseppe Luigi Balochi) had a successful premiere, in Paris in 1829, and was popular for some time after. It is likely Donizetti knew of Carafa's version when he began to compose his own. Like Donizetti, Carafa was spurred to write other works with a northern setting, drawing on Scott for his later opéra-comique 'Prison d'Édimbourg'. Other operas based on The Bride of Lammermoor were Bassi and Rieschi's La Fidanzata di Lammermoor (1833) and Mazzucato and Beltrame's La Fidanzata di Lammermoor (1834). See Mitchell, The Walter Scott Operas, pp. 105-44. John Black suggests they did not know of Mazzucato's opera, as Donizetti says in late 1835 that he was unfamiliar with Beltrame's work. See John Black, The Italian Romantic Libretto: A Study of Salvadore Cammarano, Edinburgh: Edinburgh University Press, 1984, p. 31.
} 
popular in the nineteenth century, as was Boieldieu's La Dame Blanche, based on Scott's Guy Mannering.

As William Ashbrook mentions, the subject for Lucia di Lammermoor, the third of a three-opera contract with the Teatro San Carlo, was approved by the impresario (Alessandro Lanari), after brief consultation between the composer and librettist, Salvadore Cammarano. ${ }^{57}$ Even if the subject was not initially suggested by Donizettiand as Ashbrook suggests, Donizetti did not know what the exact scenario would look like until he received the libretto - he held Cammarano in high regard. ${ }^{58}$ Donizetti went on to collaborate with Cammarano on all his serious operas between Lucia in 1835 and his departure for Paris in $1838 .^{59}$ Cammarano and Donizetti were probably interested in setting The Bride of Lammermoor for several reasons. Donizetti had already composed an opera based partly on Scott's Kenilworth, Elisabetta al Castello di Kenilworth, in 1829 (with a libretto by Andrea Leone Tottola). For him, this appears to have sparked, or at least maintained, an interest in Scotland and Scottish history - Maria Stuarda premiered less than three months after Lucia (see appendix 3 for Donizetti's British and 'Gothic' operas).

A second reason for staging another work based on Scott was that Scott himself spent part of 1831 and 1832 in Naples in the hope that it would be good for his ailing health. It is possible that some involved in the production of Lucia met him, but there is no documentation to support such a supposition in the case of Donizetti, Cammarano, or even Bellini, who was to compose an opera based on Scott (I Puritani) and who was in Naples at the time. As Mendelssohn and Klingemann had already discovered, Scott

\footnotetext{
57 Ashbrook, Donizetti and his Operas, p. 96.

${ }^{58}$ Ashbrook, Donizetti and his Operas, p. 96.

${ }^{59}$ Philip Gossett notes that Donizetti requested Cammarano specifically even when he was not associated with a particular theatre, as was the case for Belisario, which premiered in Venice at La Fenice; Philip Gossett, Divas and Scholars: Performing Italian Opera, Chicago: Chicago University Press, 2006, p. 37
} 
may not have been especially welcoming to visitors, even if he himself was the tourist. ${ }^{60}$ His stay was highly publicised though, and both Donizetti and Bellini premiered operas based on his work in 1835 .

Furthermore, by setting a work by Scott, who was strongly associated with the Romantic movement, Donizetti was attempting to extend the genre of opera by moving away from Rossinian style and working to increase opera's dramatic power. ${ }^{61}$ (A driving dramatic force was precisely what Verdi strived for in Macbeth twelve years later.) At the same time, Cammarano often drew quite clearly on other operas and performances he saw around Naples for his own texts. ${ }^{62}$ Just like the other librettists of those productions, he had no problem changing Scott's work to suit his and Donizetti's operatic genre and taste.

Cammarano was obviously concerned with the Scottish origins of his subject. As John Black has indicated, the librettist's entire output contains only four footnotes. One of these appears in Lucia and is evidence of the relative depth of thought injected into the work's setting and historical 'accuracy'. It occurs in the Act 1 finale, Lucia and Edgardo's duet. Black explains that the 'exchange of tokens...in Scotland at that time... had the force of an unbreakable oath'. In the novel, Edgar gives Lucy half of a broken piece of gold:

...the lovers going through an emblematic ceremony of their troth-plight, of which the vulgar still preserve some traces. They broke betwixt them the thin broad-piece of gold... 'And never shall this leave my bosom,' said Lucy, as she hung the piece of gold round her neck, and concealed it with her handkerchief, "until you, Edgar Ravenswood, ask me to resign it to you; and, while I wear it, never shall that heart acknowledge another love than yours'. ${ }^{63}$

\footnotetext{
${ }^{60}$ Donizetti's letters for this period are lost, as are Bellini's. See Weinstock, Donizetti and the World of Opera, p. 80.

${ }^{61}$ Ibid, p. 379.

${ }^{62}$ Ibid, p. 119.

${ }^{63}$ Walter Scott, The Bride of Lammermoor, edited by J. H. Alexander, London: Penguin, 2000, p. 158.
} 
The instructions in the opera's score call for Edgardo to 'ponendo un anello al ditto di Lucia' ['place a ring on Lucia's finger'], thereby a more specific object than a 'token'. Cammarano, citing the instruction for giving the ring, says: 'the most usual ceremony was for two lovers to break a coin, each keeping a part, but here an exchange of rings is substituted, as being more appropriate on the stage' ${ }^{64}$ That Cammarano felt compelled to footnote this prop change is telling of his quest for a sort of Scottish integrity.

However, his awareness that an exchange of rings would be more widely recognised as a mark of commitment shows that, much like the depiction of Scotland in Donizetti's musical language, the Scottish traditions are still adapted for their Italian audience and Italian operatic conventions.

Scott's Aunt, Margaret Swinton, told him the account that would become The Bride of Lammermoor. ${ }^{65}$ He also would have known other Scottish authors' supernaturally enhanced retellings of the fate of 'Lucy', in reality an aristocratic woman called Janet Dalrymple, the daughter of the Viscount Stair, and judge, James Dalrymple. ${ }^{66}$ Forced to marry her tyrannical Whig mother's choice of groom rather than the Tory Lord Rutherford, she stabbed her husband in a moment of lunacy and died soon after. ${ }^{67}$ In his novel, Scott enlarges the tale's historical and political context, and Lucy's story is one of a number of plot lines.

The reason for Lucia's marriage to Arturo in the opera is so her brother can be saved from financial ruin, more than to force advantageous political affiliations - only the vaguest hint of Scott's political narrative thread. ${ }^{68}$ There are many other changes between the novel and the opera. The most significant ones involve removing

\footnotetext{
${ }^{64}$ Black, The Italian Romantic Libretto: A Study of Salvadore Cammarano, Edinburgh: Edinburgh University Press, 1984, p. 284.

${ }^{65}$ Kathryn Sutherland, 'Introduction' in Scott, The Bride of Lammermoor, p. xvi.

${ }^{66}$ Ibid, pp. xvi-xvii

${ }^{67}$ Ibid.

${ }^{68}$ Scott himself was under much stress from his own financial ruin when writing The Bride of Lammermoor; Ibid, p. xli.
} 
characters and shifting the spotlight onto Lucy's personal story, fraught with love, betrayal and misunderstanding. Lucy's mother, Lady Ashton, is entirely removed. In the novel she is vindictive and unsympathetic to Lucy, who looks to her Father for support. Unfortunately for Lucia, he has also been eliminated in the opera, leaving her care to her brother, Enrico Ashton, who has become a character combining Lucy's parents and two brothers. He embodies more of her mother and older brother, Colonel Sholto Ashton, than her younger and frivolous bother Henry and her weak-willed father. Edgar Ravenswood, Lucy's secret Romeo-esque lover from the rival family, makes the transition from novel to opera largely unscathed. His loyal servant and confidant, Caleb Balderstone, becomes Normanno in the opera. For the French adaptation the character of Balderstone/Normanno is altered again, and in Lucie de Lammermoor he is the scheming, dastardly Gilbert who is working for both the Ravenswoods and Ashtons. Alisa, Lucia's maid in the original opera, is part-Balderstone, part-old prophetess, taking her name and gender, but little of her character, from Scott's Old Alice. ${ }^{69}$ By erasing her character, some of the novel's Gothic and superstitious tone disappears along with her. Scott based Old Alice on the witches from Shakespeare's Macbeth, who in both the play and Verdi's opera are a permeating and mysterious Gothic force. The witches control the drama, exert a powerful influence over other characters and can conjure the supernatural. These associations indicate something of Alisa's Gothic role in the novel which Cammarano removed from the opera, instead building the Gothic mood from Lucia's supernatural encounter.

Cammarano upended the plot of Lucia. Little remains of Scott's historical context and he conflates many of the novel's scenes in his adaptation. The scenario of a woman being pressured into a marriage for political gain is common enough in opera to

\footnotetext{
${ }^{69}$ In the French version, Alisa is suppressed altogether, which emphasizes Lucia's isolated position as the only woman in the opera.
} 
be easily transferable from early eighteenth-century Scotland. ${ }^{70}$ Scott has shifted his time period from 1669, when the Darymple incident purportedly occurred, to coincide with the last period of Scottish independence. There was tension in Scotland and England as supporters of Queen Anne feared a French-led Jacobite uprising and the accession of her Catholic half-brother, James Stuart. He was recognised as the rightful king of England, Scotland and Ireland in France after their father's death in 1701. Many in Scotland, especially the Highlands, supported the Jacobite cause. The Scottish Jacobites were therefore vexed by Queen Anne's failure to deliberate with the Scottish parliament over the matter of her heir and her prevention of a Catholic monarch's succession by passing the Act of Settlement in 1701. The tension between Scotland and England that ensued - and with France over the ongoing War of the Spanish Succession - was eventually resolved with Scotland agreeing to terms set in place to unite with England as Great Britain in 1707. These political affairs are The Bride of Lammermoor's foreground. Uninterested in the politics, however, and certainly with the knowledge that the subplot of Lucia's ill-starred love for Edgar would a form a superior outline for an opera, Cammarano and Donizetti adapted the novel accordingly. Unwittingly or not, there is one aspect in the opera that does point toward a political affinity not expressed in the novel. In Scott's original, Edgar never flees to France as in the opera. Edgardo's rushed return to Lucia's side from France is far more romantic than Edgar's four-mile journey on horseback from his neighbouring property. However, there is more evidence against a political agenda in Lucia to suggest that Edgardo's journey to France has any political significance. Rather, it is probably coincidental, or perhaps a logical tactic by the librettist, to highlight the historical

\footnotetext{
${ }^{70}$ This is not to say, however, that this is usually done, even modern production usually retain some reference to Scotland as other features of the work - the associations with the Scottish culture of superstition and regional music - were designed with Scotland in mind.
} 
allegiance between Scotland and France. ${ }^{71}$ The immensely increased role of Lucia, and the implications of this in considering the Gothic will be more fully discussed in the next section, but suffice to say here, that her mad scene, almost lost amongst the more prominent plot lines of the novel, is reinvigorated operatically, becoming the climax of the work.

\section{Musical 'Scottishness'}

Lucia's music, which, as we have already seen, was not described as 'Scottish' in nineteenth-century accounts of the opera, still provides hints of its location within the music. There is no pre-Verdian tinta in Lucia, an overall atmosphere to the music with recurrent musical mannerisms to enforce the unity of music and setting, but rather Scotland is revealed through musical representations of both its 'dark' Gothic side and 'cheerful' pastoral side. The episodes of Scottish couleur locale in Lucia are typical of Italian opera, mostly confined to the preludio and chorus numbers that have little effect on sustaining the dramatic momentum of the opera. The 'dark Gothicism' is implied through thematic content and the sombre tones of the preludio, yet the most concrete musical evidence of Scottish influence appears to depict, paradoxically, the "cheerful Scottish style'. Nineteenth-century 'outsiders' to Scotland represented both the 'dark Gothicism of Ossian' and the 'cheerful Scottish style' by manipulating some of the same musical techniques to create an overall 'Scottishness'. These evocations of 'Scottish style' in the music affirm the connection between the Gothic mood and Scotland, acting independently to situate the Gothic narrative within a Scottish (or northern) location, and thereby enhancing the operas' overall dark Gothic atmosphere.

\footnotetext{
${ }^{71}$ William Ashbrook, John Black and Herbert Weinstock have all noted either Donizetti or Cammarano's apathetic use of specific political situations in their works.
} 
Furthermore, the interpretation of 'Scottishness' in the music becomes based on a set of associations built on whatever other Scottish music, or folk music more generally, was familiar to Donizetti's audience. Audiences and reviewers in the nineteenth century expected a production to be set as accurately and exactly as possible, and many reviewers, as Mercedes Viale Fererro explains, had backgrounds in music, not the visual arts. ${ }^{72}$ Scotch songs were popular in France, and some of these songbooks would undoubtedly have made it across the border to Italy. A Scottish flavour is perceptible in the chorus numbers. However, the stylised nature of these tunes, which were usually not written by Scottish composers, means it is unclear whether certain numbers would have been recognisable as specifically Scottish. What is significant, though, is that the placement of the 'cheerful' Scottish idioms within chorus numbers allows the 'dark Gothicism' to exert an overall presence in the opera through a culmination of music, plot and a visually-Gothic setting.

Donizetti foreshadows the opera's Gothic scenes in the music of the preludio. Timpani rolls, which will feature later in Act 3, when Edgardo's emotional turmoil and the bitter weather match each other, alternate with a sombre horn incantation (example $1.1)$.

\footnotetext{
${ }^{72}$ Mercedes Viale Ferrero, 'Stage and Set', in Opera on Stage, edited by Lorenzo Bianco and Giorgio Pestelli and translated by Kate Singleton, Chicago: Chicago University Press, 2002, p. 31.
} 
Example 1.1: Preludio from Donizetti's Lucia di Lammermoor, bb.1-21.
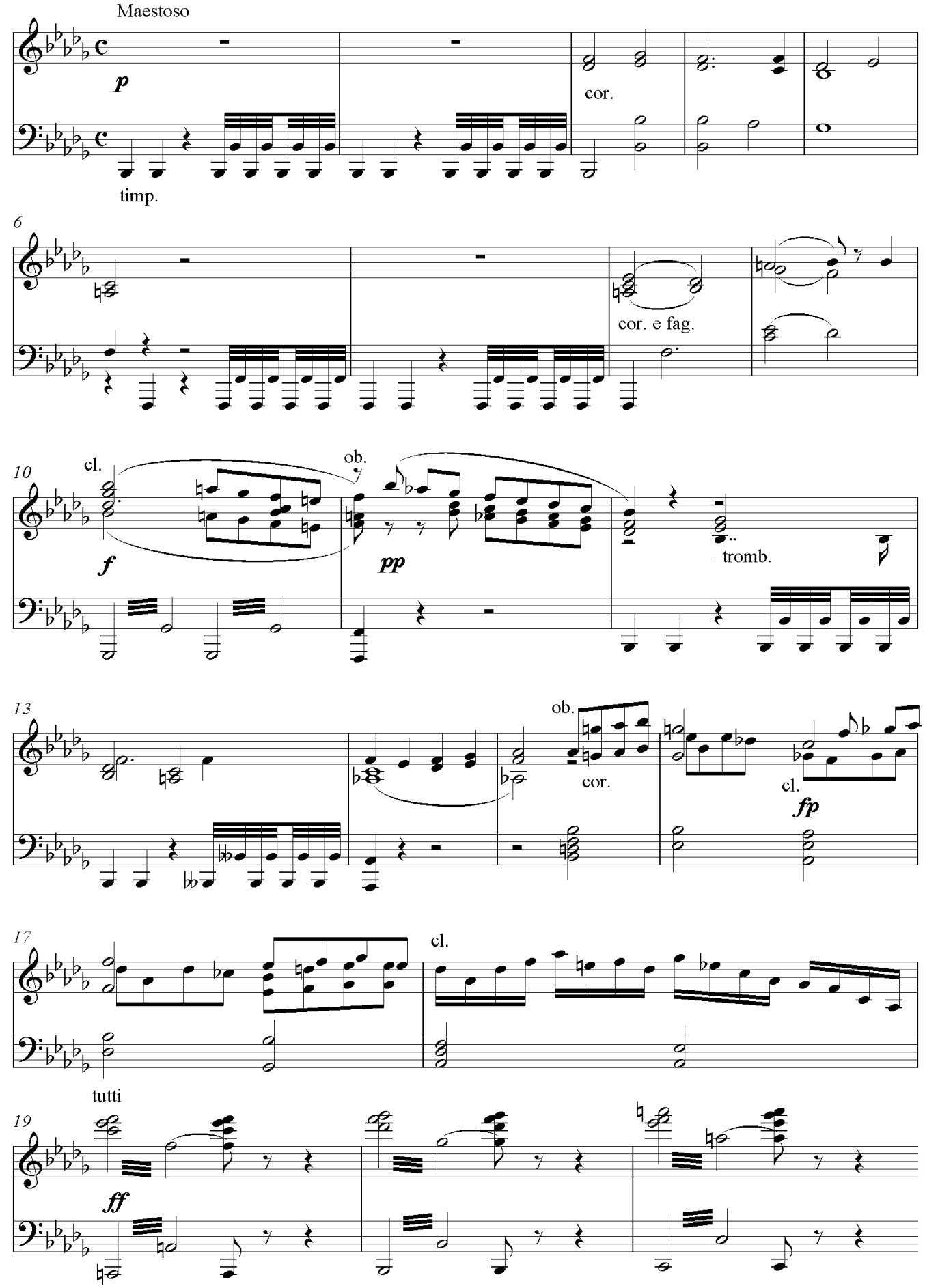
Example 1.2: Preludio from Donizetti's Lucrezia Borgia, bb.1-13.
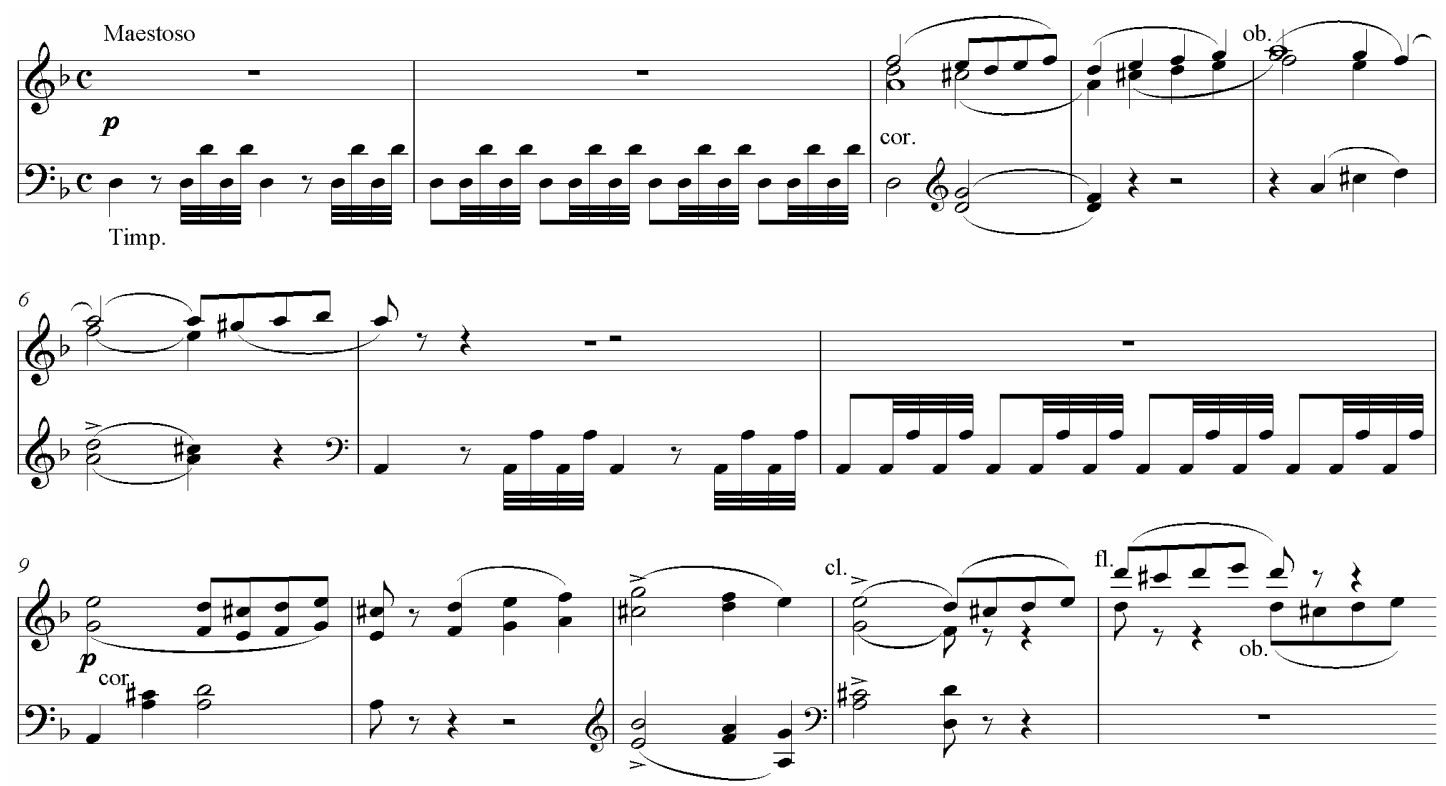

The gapped scale in bar 18 hints at a Scottish sound (though is not pentatonic, but rather an altered arpeggio), however if removed from its context, many listeners would be hard-pressed to hear it as such. The tragic tale is inescapable as a foreboding orchestral fog conceals any pastoral cheerfulness. In this moment, the connection with Scotland is at one with the Gothic. There are uncanny similarities between the preludios of Lucrezia Borgia and Donizetti's 'Scottish opera'. Both operas open with an alternation of drum rolls and a slow, step-wise ascent and descent from the horns before the woodwind enters a few bars later (example 1.2). As Lucrezia predates Lucia it suggests that the use of corresponding musical traits present a mood that can be transplanted elsewhere; that the western musical idioms overshadow a Scottish association when the sounds are removed from that contextual construction. It also suggests that perhaps this sound is more Gothic than 'northern' and that Donizetti has created a haunting and foreboding timbre, rather than one that paints only an image of locale. After the preludio, full of the dark tones marking the Gothic, the curtains part on a hunting scene, 
led by Enrico's retainer, Normanno. The musical depiction of Scotland disappears as Donizetti's score here bears little in common with traits perceived as Scottish, and often used to symbolise the country.

The music of the hunting chorus that follows the preludio is not in the pentatonic or hexatonic, nor any of the diatonic modes, but Collinson explains that a Scottish character must come from more than the gapped scalic patterns. He notes that another feature of Scotch songs is that they frequently begin in one key and end in another, which once again does not occur in Donizetti's music. The interlude between the preludio and Normanno's first entrance begins in the dominant minor and ends in the dominant major, but the chorus itself begins and ends in the tonic of B flat major. A consequence of this tonal shift in Scottish music is that it often renders parts of the text incompatible with the music, something that arguably does occur in the hunting chorus. ${ }^{73}$ Nonetheless, this paradox between text and music probably cannot be completely explained by a quest for 'Scottishness' on Donizetti’s part. Instead, equating Scottishness with cheeriness would appear to justify Donizetti's placement of the most 'Scottish' numbers of the opera - the Act 2 and 3 choruses 'Per te d'immenso giubilo' and 'D'immenso giubilo s'innalzi un grido' respectively. In the opening hunting chorus the men sing:

Percorrete le spiagge vicine. Percorriamo le spiagge vicine, della torre le vaste rovine, cada il vel di sì turpe mistero lo domanda, lo impone l'onor. Splenderà l'esecrabile vero come lampo fra nubi d'orror.

[Cover the neighbouring shores.

Let us cover the neighbouring shores, By the vast ruins of the tower,

\footnotetext{
${ }^{73}$ Francis Collinson, The Traditional and National Music of Scotland, London: Routledge and Kegan Paul, 1966, pp. 21-23.
} 
Drop the veil from this wicked mystery

Honour demands it, honour implores it.

The execrable truth will flash

Like lightening between clouds of horror.]

The text itself makes no mention of Scotland specifically, and the ruins, while part of Scotland's historical landscape, are a general Gothic omen. The 'esecrabile vero' first sung by Normanno and then taken up by the chorus, is presumably Lucia's relationship with Edgardo, her brother's enemy, and a contributing factor in her refusal to marry Arturo. Normanno reveals their relationship on Enrico's entrance. The text also implies it is Edgardo they are hunting. The men's sweep of the area includes the tower, his crumbling home, and the location for the stormy confrontation between Edgardo and Enrico in Act 3, scene 1 (the Wolfscrag scene). Nonetheless, the conventions of nineteenth-century Italian opera tend to trump notions of word painting or even expectations of general mood, thus any degree of 'Scottishness' is still subordinated to Italian style. The textual and musical disjunctions create a sense of uncanniness regardless. It is as though Donizetti felt that he had to use a conventional 'cheerful style' here, as in spite of the way it seems completely adverse to the text, a 'darker' tone would not depict the necessary 'Scottishness' to connect with the chorus of Scottish guards.

Collinson names a particular 'cliché' as the sequencing of melodic lines based around a major triad. This, like the grace notes he also claims to be part of the Scottish musical language, does appear in Donizetti's hunting chorus. Yet it is a problematic claim to say that these two features must indicate the opera's setting. They are by no means overused; rather they appear fleetingly and inconspicuously, part of the pleasant musical mood, and also set against the Gothic textual references. 
Example 1.3: Hunting chorus from Act 1, scene 1 of Donizetti's Lucia di Lammermoor, bb. 64-90. 
Much of the sequencing of the hunting chorus does not function as sustained melody. Rather it fills gaps between the vocal phrases or accentuates the repetition of certain words. The sequences are most obvious in the allegro section, played by the strings (which Collinson says often use the technique originally adopted from bagpipe scales) (example 1.3). ${ }^{74}$ The acciacciature, occurring immediately before new vocal melodic material, are subtle anticipatory notes. Pastoral music is often characterised by drones, which are reminiscent of the bagpipes in a Scottish setting. The beginnings of a drone occur in the instrumental introduction to the Act 1 chorus, in the double bass and horns, but it is not sustained, nor does it return in the music to follow, displaced by the alternating two-bar phrases of driving brass and the jaunty melodic descent from the winds. Consequently, the instrumentation of the first scene is as unremarkable as the vocal line itself and the audience must rely on the visual elements of the staging to portray Scotland.

We might expect couleur locale, hints of the setting within the music, to be most apparent in the chorus's music for a number of reasons, most obviously because they are representative of the local people. For them, singing music with a Scottish lilt is the musical equivalent of speaking with a regional accent. In Scott's novel, the lower-class characters speak with a heavy Scottish accent, yet in the speech of the aristocratic members of the Ashton family and Edgar Ravenswood a Scottish accent is undetectable. Even so, an equivalent distinction is not heard in Donizetti's score, as when the 'Scottish' music appears it then seems to spread from the chorus music into Arturo's line - the only 'real' aristocratic character of the opera. ${ }^{75}$ The principal characters are not conspicuously separated from the chorus by class, but they are mostly distinguished

\footnotetext{
${ }^{74}$ Ibid, pp. 24-5.

${ }^{75}$ While the two feuding families could both be considered of noble origin, the Ashtons have forced the Ravenswoods into financial ruin, and are now little better off themselves - hence the need for the fortuitous marriage of Lucia to Arturo.
} 
by their musical representation. Scottish idioms are rarely used in the music of the principal characters, where the emotional portrayal essential to opera seria is unequivocal. Pointers towards a Scottish style or a pastoral spirit are only obvious in the chorus numbers, where individual character development is not a concern (thus Lucia is typical of most operas). Lucia herself seems to have no musical affiliation to Scotland in her mannerisms. The disturbed musical form of her cavatina is indicative of her Gothic setting. It is significant that at no point does she regress to the state of uncouthness that occurs in her madness in Scott's novel, where her use of Scottish dialect removes the tentative link she still holds with the aristocracy - instead Lucia is taken to the boundaries both of reason and of civility. At this moment there is no evidence of Scotland in the music, instead Donizetti is entirely consumed in depicting her state of mind and does not link it to her nationality. Lucia's role in general, as the serious, tragic heroine, is expressed in an Italian musical vernacular. ${ }^{76}$

The chorus are gathered for Lucia's wedding to Arturo, and the mood is one of excited anticipation, which leaves them out of touch with the realities of the Gothic situation. They are unaware that Lucia has just been bullied into the marriage by Enrico and Raimondo. While the darker Gothic mood is not evoked musically as specifically Scottish, in the Act 2 and 3 chorus numbers it is improbable the choruses' 'cheerfulness' is solely a vehicle for Scottish local colour, as the musical mood is appropriate for a wedding celebration and thus directly corresponds to the mood of the libretto. Donizetti may have recognised that the 'cheerful Scotch style' of music was incongruous with particular Gothic episodes or scenes of high emotion, and limited 'Scottishness' for the sake of dramatic continuity by placing it within a context that calls for 'cheerfulness' anyway.

\footnotetext{
${ }^{76}$ The gross exception to this could be the use of harp in the introduction to her cavatina, 'regnava nel silenzio', which will be further explored in part two.
} 
In Lucrezia Borgia, Romani (taking most of his historical licence from Hugo) centred much of the action around the purportedly frequent and extravagant parties of the Venetian nobility. This celebratory environment would appear to offer an ideal comparison for the 'Scottish' and 'English' music Donizetti uses to connect his northern settings to the Gothic, as in Lucrezia Borgia the dances could be expected to convey an Italianate style. Indeed, Ashbrook notes that the music comprises 'blatant dance rhythms and passionate catilena' ${ }^{77}$ Thus Donizetti's score embodies the opera's Italian Renaissance setting in a similar way that 'Scottishness' is apparent in Lucia.

The Act 2 and 3 chorus numbers of Lucia are reminiscent of Scottish folk dances (examples 1.4 and 1.5). One of the opera's few verbal references to its setting appears in the Act 3 chorus:

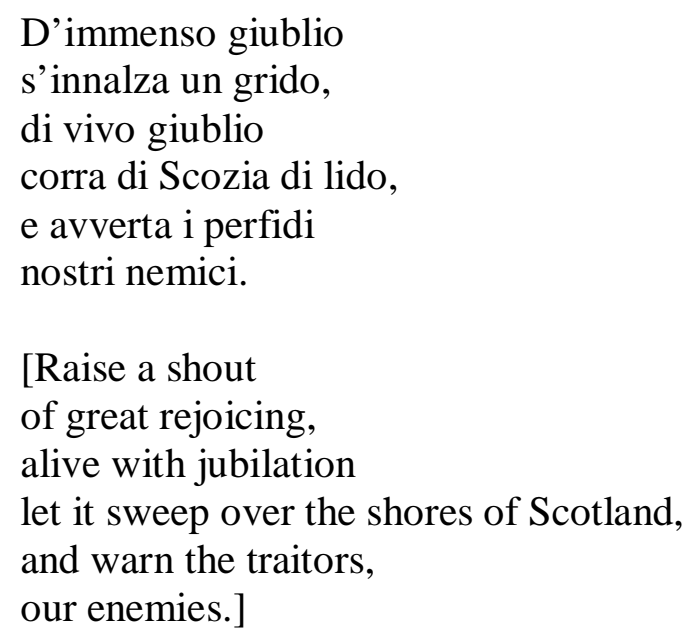

In the Act 2 chorus, the note in the libretto says nothing about the music: 'Sala preparata pel ricevimento di Arturo. - Nel fondo, porta praticabile' ['prepared room for the reception of Arturo. - in the background, a workable door'].

${ }^{77}$ Ashbrook, Donizetti and His Operas, p. 349. 
Example 1.4: 'Per te d'immenso giubilo' from Act 2, scene 2 in Donizetti's Lucia di Lammermoor, bb. 20-35.
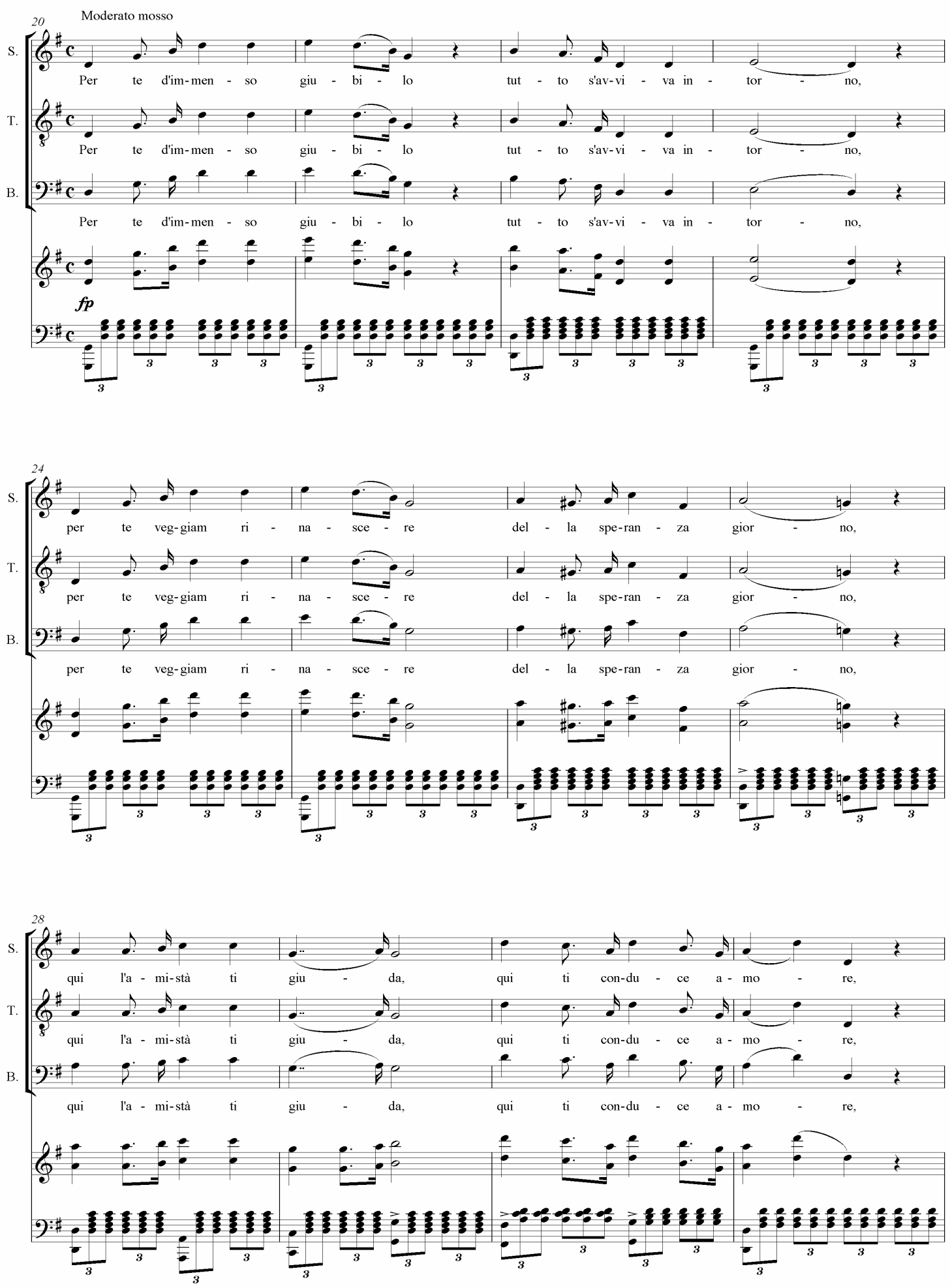


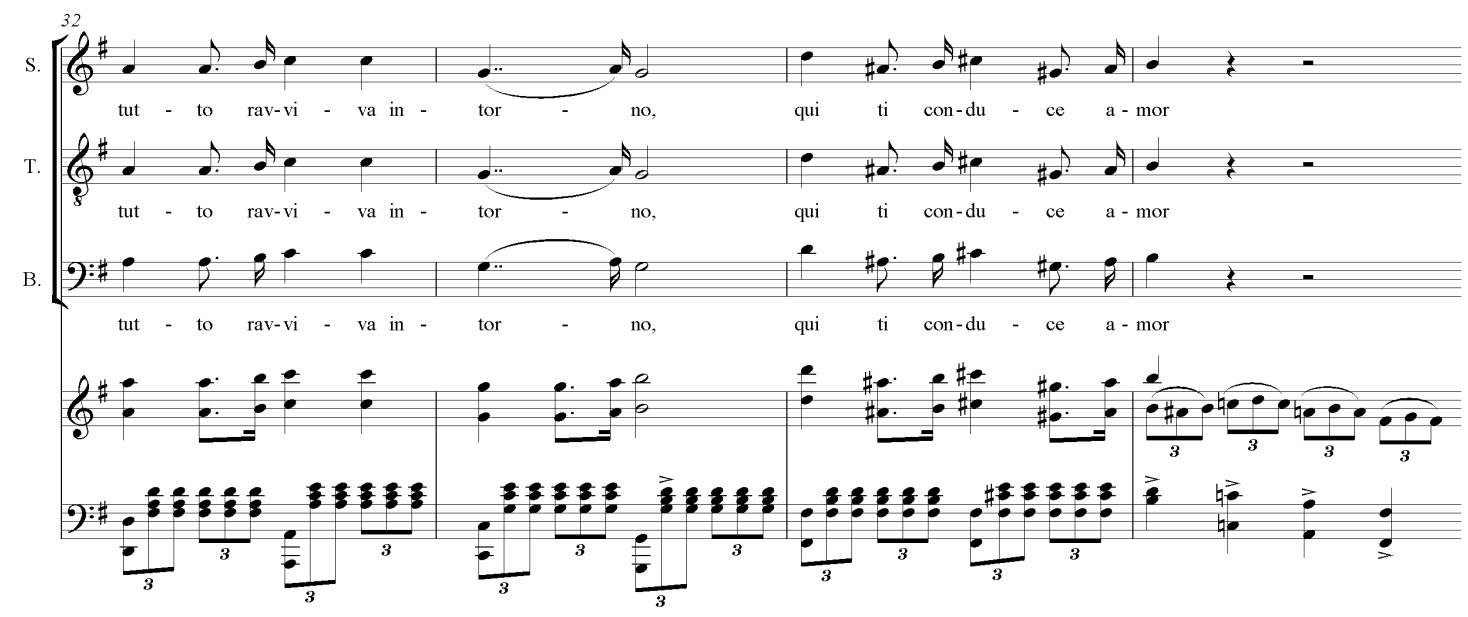

However, the music is referred to in the Act 3 chorus: 'Dalle sale contigue si ascolta la musica di liete danze. Il fondo scena è ingombro di abitanti del Castello di Lammermoor'. ['From the adjacent rooms cheerful dance music can be heard. The background scene is crowded with the inhabitants of the Lammermoor castle'.] This description underpins the musical 'Scottishness' and strengthens the number's representation of Scotland. Scottish country dances were traditionally performed by the upper classes and gentry at weddings and other social occasions. In both choruses the music has a strong simple metre, symmetrical four and eight-bar phrasing and melodic sequencing, (though in the third Act chorus there is more imitation than sequencing). However, these features are common in dance music generally and two 'keys' that would unlock the music as a typical representation of Scotland are missing and therefore enforce Donizetti's Italian musical language. The music remains diatonic, mainly in G major (Act 2) and E major (Act 3), and there are no Scotch snaps. Any dotted rhythms are configured as long-short, rather than short-long. Consequently, the character of the chorus music alone could just as easily be interpreted as either a facet of Donizetti's Italianate style or his assertion of musical 'Scottishness'. 
Collinson states that 'musically, the strathspey (a Scottish dance), is characterised by its dotted quaver-semiquaver rhythm and the inversion of this, the 'Scotch snap', although what was deduced as quintessentially 'Scottish' by an audience was not necessarily true to real examples. ${ }^{78}$ While these 'uninverted' dotted rhythms could testify that in fact an audience may have heard the music as 'Scottish' regardless of the rhythmical inflection, the music nonetheless remains encased in Italian operatic conventions. However, of these two chorus numbers, the first, in common time and at a moderate tempo (moderato mosso), implies a strathspey. In performance, strathspeys are typically followed by a reel. It may not be coincidental that Donizetti has used a number of conventions of the reel in the third act chorus. These include the $2 / 4$ measure and faster tempo (allegro vivace), although the emphasis is on quaver-semiquaver and sequenced semiquaver patterns, rather than the reel's characteristic 'rapid but smooth-flowing quaver movement' ${ }^{79}$ Only the third Act chorus is named as a dance, but the relationship between the two choruses suggests the earlier number is also a dance, as Donizetti has applied the same musical mannerisms. The instrumentation could also suggest these 'dance-choruses' are based on Scottish tunes. The piccolo is reminiscent of the tin-whistle common in both Scottish and Irish music, and the music is rhythmically driven by virtually the whole percussion section in both numbers: timpani, bass drum, cymbal and triangle. ${ }^{80}$ It is not surprising Donizetti refrains from using bagpipes. There would have been practical difficulties of finding a player, or timbral imbalances within the orchestra - not to mention that Donizetti may not have been primarily trying to depict Scotland in the music.

\footnotetext{
${ }^{78}$ Francis Collinson, 'Strathspey', in Grove Music Online, Oxford Music Online, http://www.oxfordmusiconline.com/subscriber/article/grove/music/26909, (8 April 2010).

${ }^{79}$ Francis Collinson, 'Reel', in Grove Music Online, Oxford Music Online, http://www.oxfordmusiconline.com/subscriber/article/grove/music/23050, (8 April 2010).

80 The only other percussion instrument called for is a cowbell, which sounds only as Lucia's death knell in the finale scene.
} 
Example 1.5: 'D'immeso giubilo', Act 3, scene 2 from Donizetti's Lucia di Lammermoor, bb. 34-74.
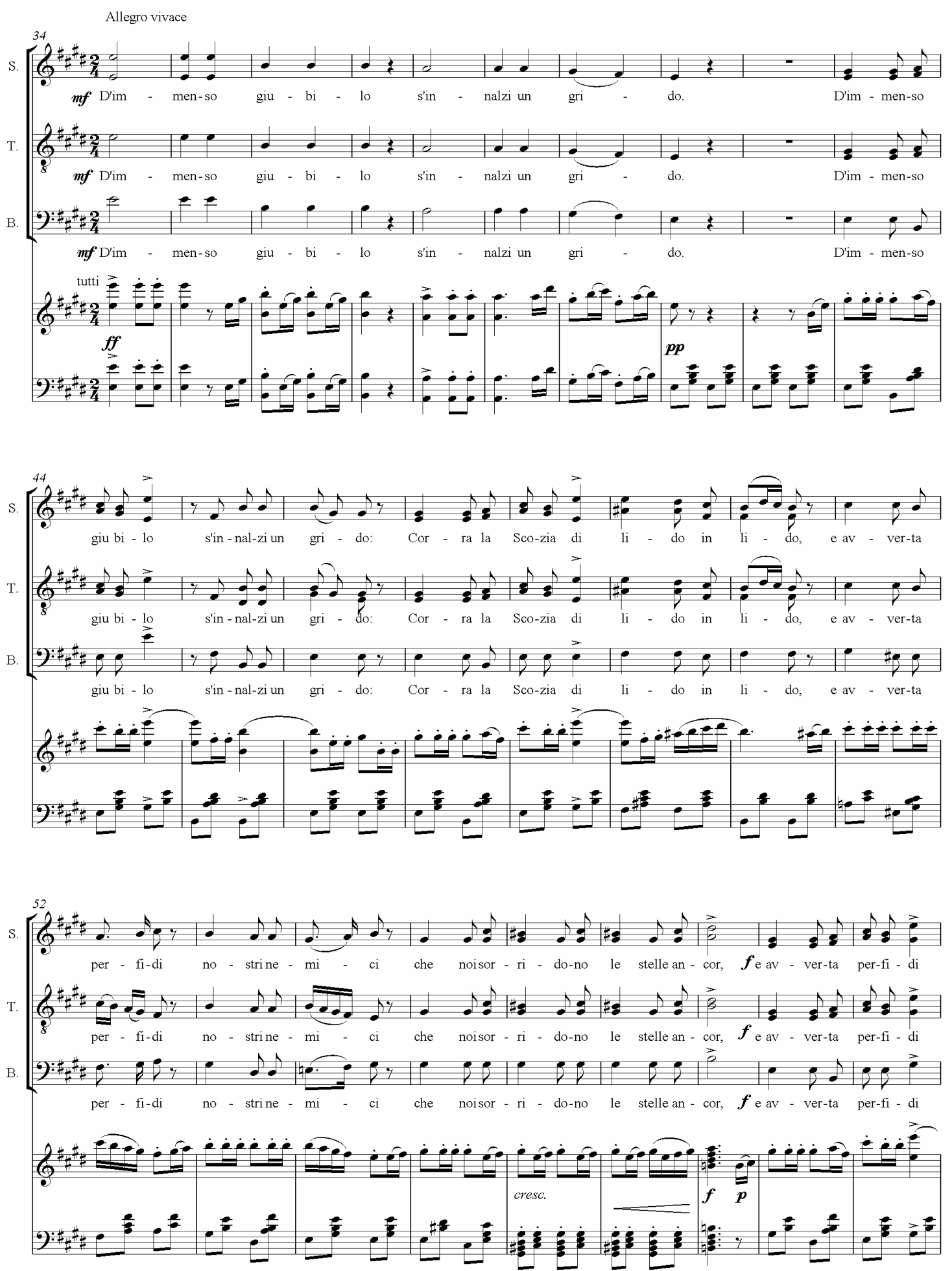


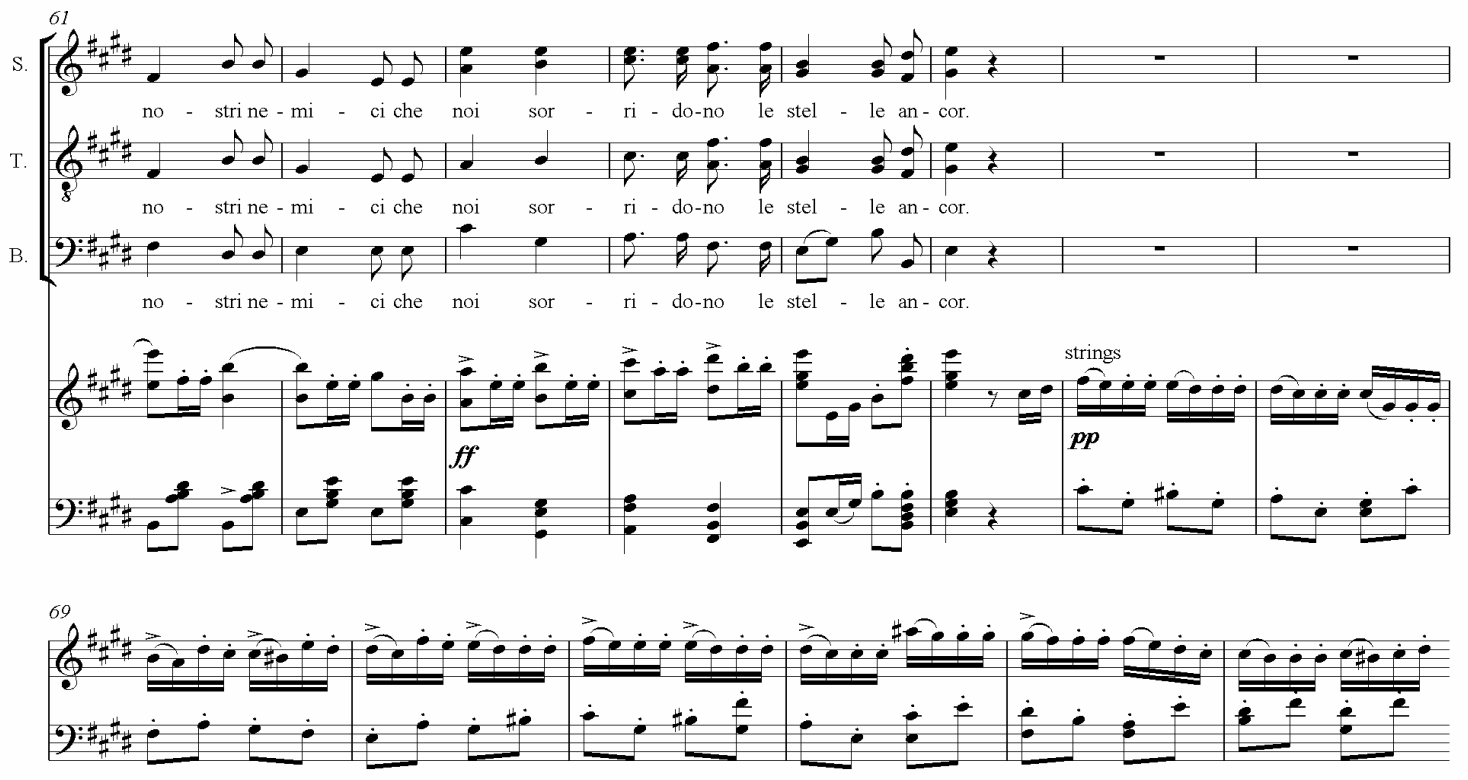

What is more, there are no traditional pibroch idioms or imitations of drones, highly ornamented idiomatic lines, or the type of 'theme-and-variations style' most often performed by pipers.

Even though modern productions often have the chorus dance at least during the Act 3 chorus, it is unlikely the chorus would have danced in early productions of Lucia. The dance music is heard coming from an adjoining room, and neither the libretto nor Cammarano's instructions for the staging of Lucia mention the chorus dancing. ${ }^{81}$ Rather Cammarano directs that 'everybody enters from the left. Half the chorus women, similarly half the chorus men, place themselves on the right, the rest on the left'. ${ }^{82}$

When other 'northern' and 'Gothic' operas are seen alongside Lucia, the unusual treatment of the chorus among Donizetti's 'northern' operas is clearer, albeit still well

\footnotetext{
${ }^{81}$ Cammarano's notes were presumably for another theatre staging the work, and appear to only be in a hurried, draft form. See John Black, 'Cammarano's Notes for the Staging of Lucia di Lammermoor', Donizetti Society Journal, Vol. 4, 1980, p. 30.

${ }^{82}$ John Black, 'Cammarano's Notes for the Staging of Lucia di Lammermoor', p. 37.
} 
within Italian operatic conventions. It is more common for Donizetti to attempt dramatic continuity than for him to break with the tragic and Gothic mood. Therefore, while it seems much of the 'Scottishness' or 'Englishness' in the scores of his Britishset operas is uncharacteristically cheerful and in sharp contrast to the Gothic, unless the events especially require it, most descriptive, scene-setting music lasts no more than a few bars and thus does not intrude on the overarching dark Gothicism associated with the north. This contrast between moods is also important dramatically, heightening the sense of rupture between the individual and the community. Lucia could be considered a threat to the social fabric of the opera presented by the chorus - the 'cheerful' Scottishness - through her direct associations with the Gothic narrative and her resistance to typical social and musical forms.

The most blatant example of 'northern' musical appropriation occurs in Donizetti's final British opera, Roberto Devereux, Conte d'Essex, where the principal theme of the opening sinfonia is 'God Save the Queen'. The other themes hint at a 'northern' style in their heavily dotted rhythms, rapid sequenced quaver passages and jangly percussion reminiscent of the 'Scottish' music of Lucia and of English folk tunes (particularly Morris dancing, where bells and tambourines are attached to the dancers to sound with their every movement). The sinfonia in Roberto Devereux was one of the additions Donizetti made for Paris in 1838. The preludio of the original version contains little to enforce the English setting, but the arrival of Elisabetta is signalled by a regal-sounding dotted melody in which traces of 'God Save the Queen' are audible (examples 1.6 and 1.7). Donizetti left his most overt Gothic episode untouched, where, in the final scene, Elisabetta is 'beset by avenging visions' of those she has sentenced to death: her lover, Roberto; the woman he is enamoured by, Sara; and her husband, the Duke of Nottingham. 
Example 1.6: Sinfonia from Donizetti's Roberto Devereux, bb. 10-29.
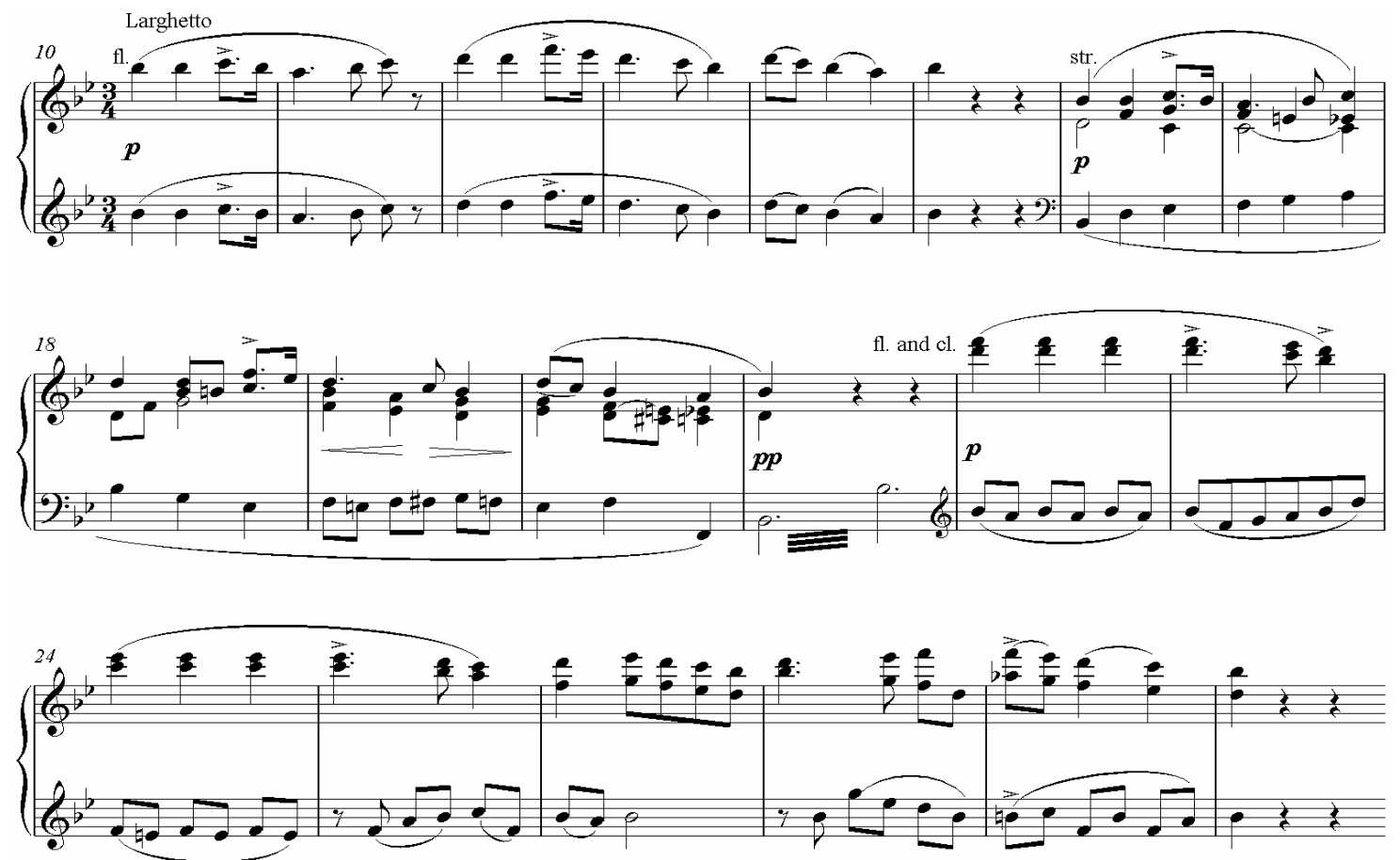

Example 1.7: Elisabetta's entrance for her cavatina in Act 1, scene 2 of Donizetti's Roberto Devereux, bb. $1-6$.

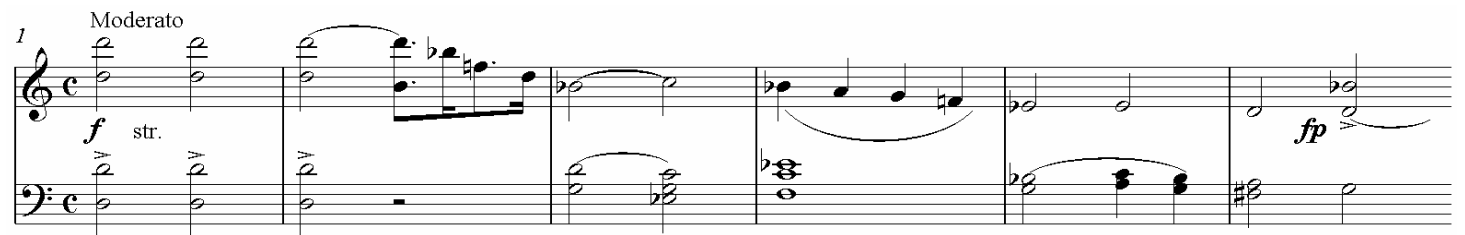

At the same time as Donizetti added the sinfonia to represent the location of the opera, he also added 'Bagnato il sen di lagrime', Roberto's aria in the tower scene in Act 3, in which he realises he is powerless to save Sara from her certain death. This aria recalls the music of the sinfonia'sthird section, but now its brisk, sanguine mood seems as unsettling as the musical and textual mismatching of Lucia's hunting chorus. These moments are evidence that the convivial and celebratory music and the dramatic Gothic 
plot cannot gel together, but instead serve to illuminate each other and portray the close connections between the north and the Gothic.

A lack of distinction between 'northern' style and the all-embracing Gothic tone is particularly apparent in Anna Bolena where, unlike Lucia, the chorus has no celebratory moment with snaps or sequences. Indeed, in Anna Bolena's tragic story there is no celebrating of any kind - the 'hunt' is but a fleeting five-bar moment in the horns. The chorus's biggest number, just before the Act 2 finale as Anna's imminent death draws nearer, is a lament of her imprisonment - hardly the place for a merry dance tune. Anna Bolena has no numbers to act as respite from the dramatic tension of the opera's scenario or instances of couleur locale near the beginning to create a regional feel. The scenes continue on their tragic trajectory uninterrupted. The overture too, where some illustration of setting might be evident, contains no hint of its English setting. Herbert Weinstock comments that the overture to Anna Bolena was an act of Donizetti's self-borrowing, with the allegro theme taken from the overture to his earlier work, Alina, Regina di Golconda (1828). Another theme from Alina also made its way into the Anna Bolena overture. In addition to this, Ashbrook indicates that there were additional borrowings made from four other operas Donizetti composed for Naples in the 1820s. ${ }^{83}$ Therefore, some parts were not written with England in mind, even if Donizetti felt they successfully evoked the dramatic resonance he required. In Anna Bolena the scenery carries all the weight of portraying the location of the action - and the costumes too convey an English specificity. Overall, in his second opera on an English subject (after Elisabetta), there is scarcely anything on which to base an argument for Donizetti's use of 'English' mannerisms.

\footnotetext{
${ }^{83}$ These include Otto mese in due ore, Il paria, Imelda and Enrico di Borgogna. See Ashbrook, Donizetti and his Operas, p. 317.
} 
The difference with Lucia is that the chorus offer an outside perspective.

Oblivious to happenings behind the scenes, they do not have as intricate an understanding of Lucia's situation as the audience, who have seen the Act 2 duet between Lucia and Enrico (where Lucia is victimised and driven into marriage by her brother), and therefore the chorus are not necessarily perceived as a social voice. The chorus in Lucia are comparable in this respect to the chorus in Verdi's Macbeth, who, at the beginning of the brindisi, do not contemplate their new King is the murderer of Duncan and Banco. Lucia's wedding guests only gradually become aware of the awful situation as the action progresses, first when Raimondo enters, then by witnessing the descent of Lucia herself.

By comparing works such as Anna Bolena with Lucia, the significance of Scotland and its perception by Italians as an exoticised country is discernable. The Gothic in Anna Bolena is perceivable through the thematic content and characters less forcefully than in Lucia, where the Scottish 'interludes' enliven the setting while also being inherent to the Gothic. That the 'Scottish' music in Lucia is predominantly linked to the chorus could also be explained by the Gothic's distinction as a 'high' art genre. This has the connotations of elite society and their artistic taste, and of conveying a tragic dramatic tension in which the principal characters must portray emotional depth. The chorus, Lammermoor locals, instead perform 'low' art popular tunes, superficial to the Gothic dramaturgy. The implication taken from Scott is that the hunting party and some wedding guests are servants, of a lower class than the 'ruling' class of the Ravenswoods and Ashtons. However, Senici notes that one of the reasons composers set their operas in the countryside was to escape the rigid class structure of urban areas, and class is less apparent in Lucia than in The Bride of Lammermoor. Class no longer distinguishes the wedding guests, and the hunting party is now comprised of guards, not 
retainers, thereby renouncing any social distinctions and smoothing the divisions between the 'low' 'cheerful style' and the 'high', 'dark Gothicism' of Scotland.

The couleur locale Donizetti employs in his northern operas, from Elisabetta to Roberto Devereux, appears on a sliding scale, from the glaringly obvious adoption of national song and the appropriation of 'British' style to subtle orchestral suggestions. Moreover, by setting the most discernible examples of couleur locale at the beginning or in numbers in which the principal characters do not take part, Donizetti confines the cheerful, pastoral associations. The connection Scotland has with the Gothic is illuminated musically by using the cheerful, pastoral style to construct the locale. By positioning the choruses' dance music later in Lucia, the chorus numbers act as a type of reminder to the audience that this unruly, other-worldly Gothic situation epitomises Scotland. The placement of these brief 'Scottish' forays in the drama work in favour of interpreting the works by and large as Gothic. While these instances of musical scenepainting have little dramatic weight, they act independently of the overall Gothic mood and strengthen the role of the Gothic by providing a foil or opposition that makes the Gothic appear more striking. Instead of undermining the Gothic with the cheerful pastoral-orientated mood, the local colour reinforces Scotland or England in the most recognisable way. It connects the cheerful style with the dark Gothicism. It adds another level of understanding about the remote north, which remains veiled in the darkness and violence of the past and unenlightened thought.

The Visual Gothic

Whether the first Italian audiences could hear 'Scottishness' in Lucia or not, they certainly would have seen it. The typical sets and costumes of nineteenth-century 
productions loudly conveyed the opera's location, binding the Scottish with the Gothic. In addition to being the opera's librettist, Cammarano was in charge of the stage direction at the Teatro San Carlo between 1834 and 1852 under his role as 'poeta e concertatore'. ${ }^{84}$ He was in charge of giving information about costume, scenery and prop requirements to Lanari, the impresario. In addition to Lucia, Cammarano was also involved in a production of Anna Bolena for the San Carlo in 1834. Although there is uncertainty as to whether this production was that of the premiere or a new one, Cammarano's descriptions match the original sketches for the premiere by Alessandro Sanquirico. ${ }^{85}$ What is perhaps most interesting about the visuals for Anna Bolena is how they work with the music as the basis of the Gothic mood. From the stage design it is evident that the historical accuracy was more important than any depiction of the Gothic, but the Gothic is evident in most scenes regardless through the architecture of the Middle Ages and the nineteenth-century Gothic revival. Windsor castle, where the opera is initially situated, is a medieval fortress, although, like the Tower of London in which the later part of Anna Bolena is set, it underwent many changes, additions and demolitions throughout the centuries. Rather than a Gothic ruin, the rooms and buildings of Sanquirico's sets are sumptuously detailed, and not unlike the Castle as it was in the nineteenth century. Indeed the Queen's chamber is Classically styled, as was much of the castle before interior changes in the early nineteenth century, and Cammarano captions it as a 'room in Windsor Castle, in the Queen's apartments. It is illuminated as it is night-time' (figure 1.1). ${ }^{86}$ The first act of the opera requires two other scenes as elaborate as this, a park outside the castle and the public entrance chamber attached to the Queen's room.

\footnotetext{
${ }_{85}^{84}$ Black, 'Cammarano's Notes for the Staging of Lucia di Lammermoor', p. 29.

${ }^{85}$ Sanquirico was a preeminent costume designer for ballet and opera who worked chiefly in the theatres of Milan.

${ }^{86}$ Black, The Italian Romantic Libretto, p. 274.
} 


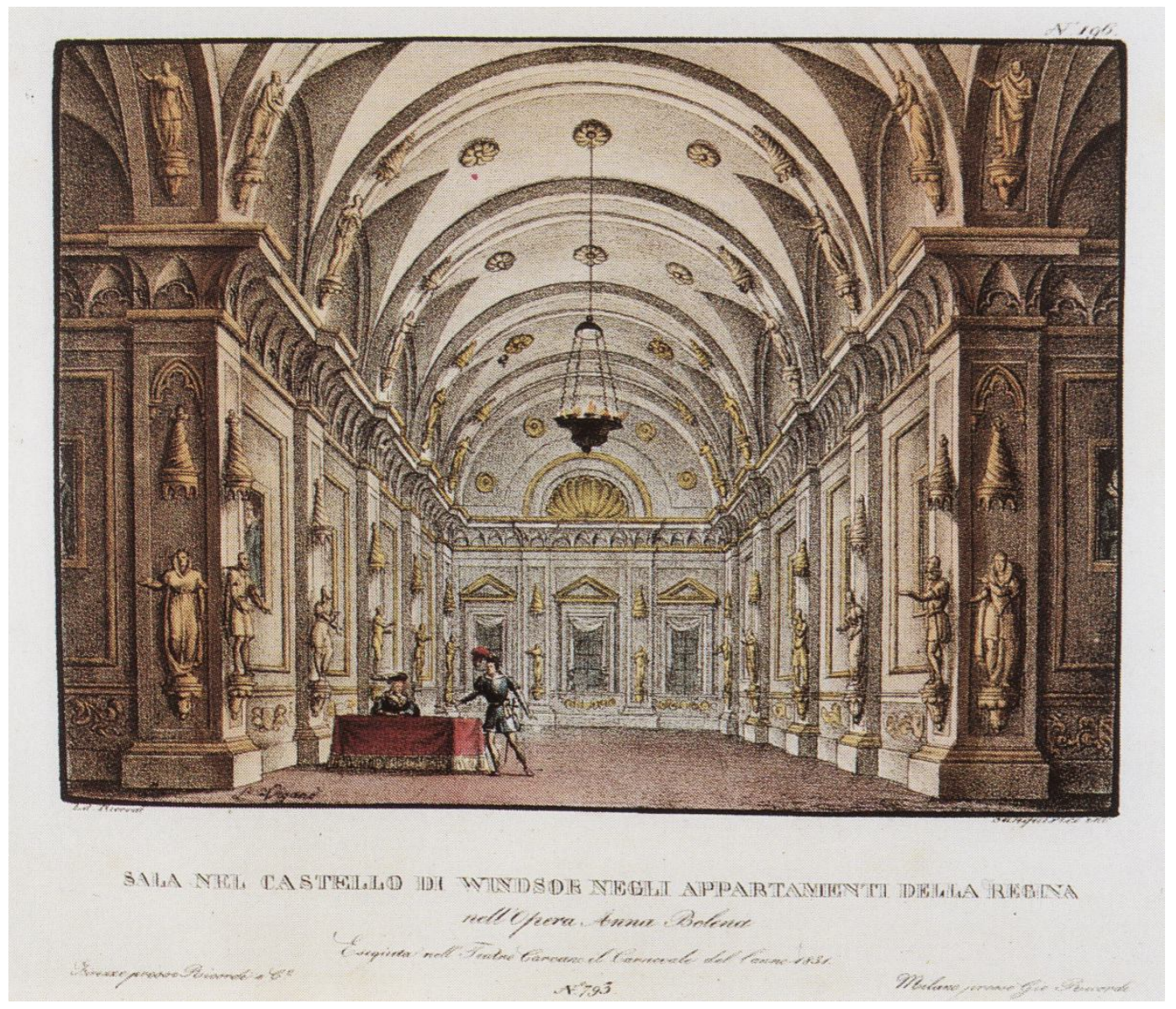

Figure 1.1: 'Sala nel Castello di Windsor negli appartamenti delle regina', Alessandro Sanquirico, stage design for Act 1, scene 1 of Donizetti’s Anna Bolena ( Milan, Teatre Carcano, 1830).

The scenery for Act 1, scene 2, the park at Windsor Castle, reveals a familiar composition in Romantic art (figure 1.2). Nature frames history, towering above and beyond the figures (presumably Henry in black and Percy in red). John Constable, the English naturalist landscape painter who famously painted his own familiar surroundings, saw landscape painting as an equally valid genre to the popular English history paintings of the early nineteenth century. The impression of the well-established trees in the foreground of Sanquirico's design gives the Italian audience almost as much of a sense of the opera's historical setting as Windsor Castle in the background and is reminiscent of Constable's 1825 painting, Salisbury Cathedral from the Bishop's Garden (figure 1.3). This scene represents a peaceful and picturesque setting, the trees' 
warped trunks tend towards a natural wildness. Constable was known by the 1820 s for painting landscapes in a quintessentially English manner, and thus Sanquirico's composition is representative of England in itself. ${ }^{87}$ By 1824, Constable's work had found fame in France, where he was commissioned to undertake a series of works for engraving, but whether the Italian public would have been familiar with his work is uncertain.

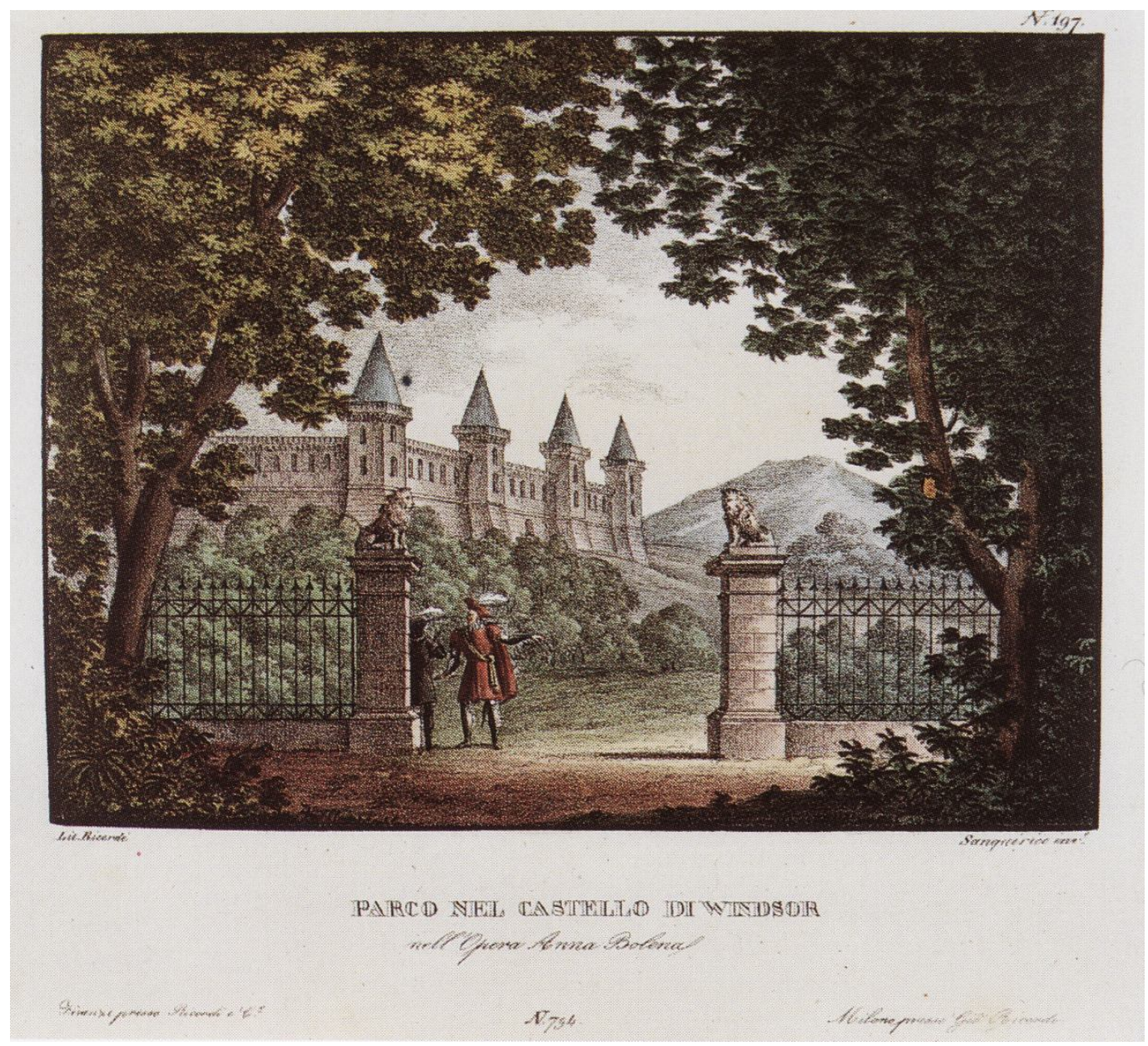

Figure 1.2: 'Parco nel Castello di Windsor', Alessandro Sanquirico, stage design for Act 1, scene 2 of Donizetti's Anna Bolena ( Milan, Teatre Carcano, 1830). ${ }^{88}$

\footnotetext{
${ }^{87}$ Michael Rosenthal, 'Constable, John', Grove Art Online, Oxford Art Online, http://www.oxfordartonline.com/subscriber/article/grove/art/T019150, (12 February 2010).

${ }^{88}$ Cammarano labels this as scene 2, but in Le Prime Representazione delle opere di Donizetti Bini and Commons cite it as scene 6. For continuity, I will adhere to Cammarano's numbering.
} 


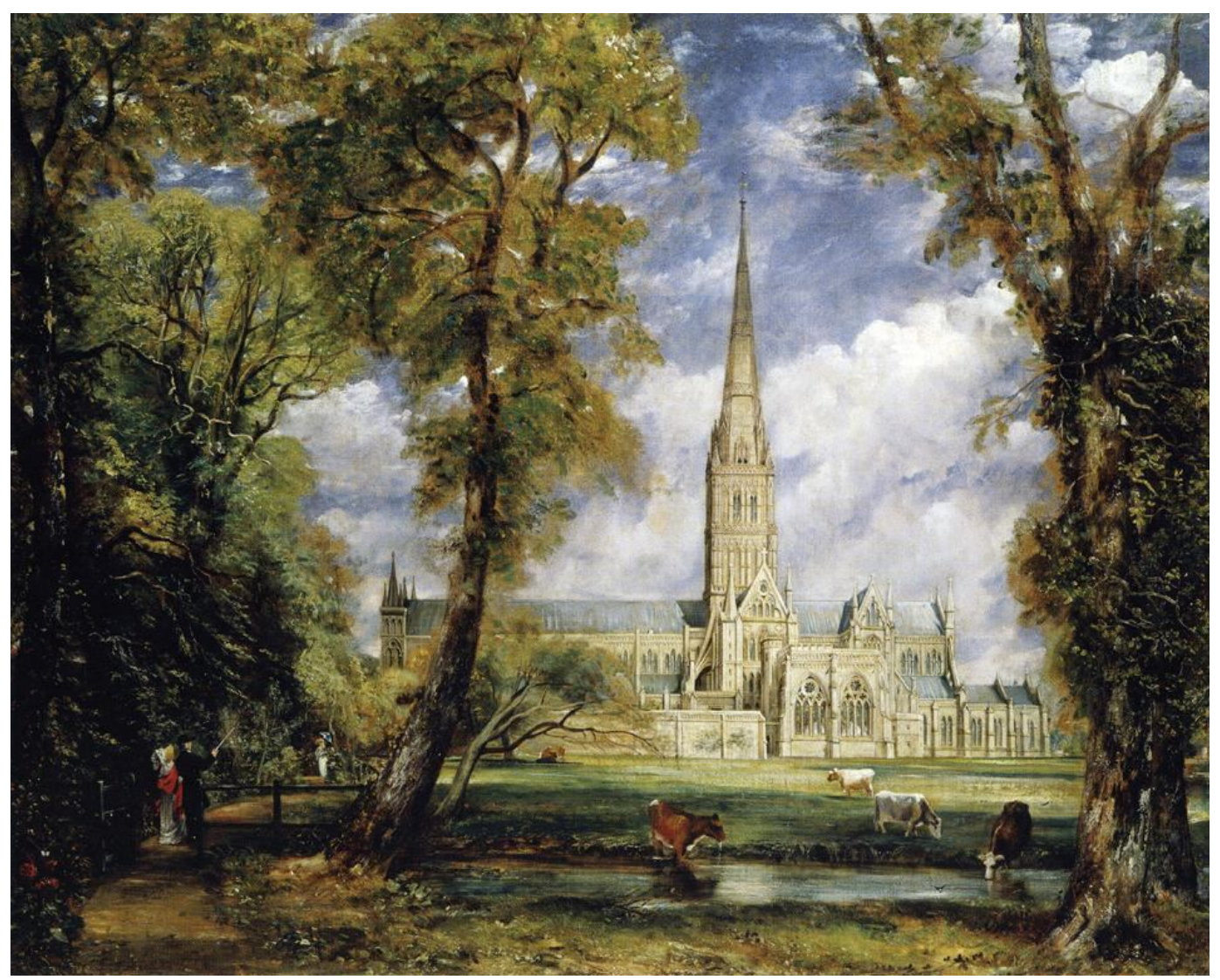

Figure 1.3: John Constable's Salisbury Cathedral from the Bishop's Garden, (1825).

In their enquiry into ballet costumes designed by Sanquirico and a number of other hands at La Scala in the 1820s, Mercedes Viale Ferrero and Francesca Franchi discuss the procedures for costuming. Viale Ferrero and Franchi explain that a number of signatures appear on the drawings, indicating costumes were checked for their authenticity' to the period and location. ${ }^{89}$ For the ballet costumes, this included the librarian Robustiano Gironi, who was in charge of finding 'authentic' pictorial sources on which to base the costumes. These sources are occasionally cited on the designs. As many of the same people worked in the various Milanese theatres, the methods at the Teatro Carcano where Anna Bolena premiered were undoubtedly similar. It is also

\footnotetext{
${ }^{89}$ Mercedes Viale Ferrero and Francesca Franchi, 'Costume Designs by Alessandro Sanquirico and Others for Ballets Performed at the Teatro alla Scala, Milan 1820-24', The Journal of the Society for Dance Research, Vol. 2, No. 2 (Summer 1984), pp. 26-27.
} 
highly probable that these methods of designing costumes extended to the sets. In that case, Sanquirico, perhaps aided by Gironi or another librarian, would have researched the most appropriate representation of Windsor Castle, the surrounding landscape and the Tower of London after receiving the instructions from the stage director. Even if the Italian audience would not have immediately recognised the park scene as an imitation of English art, the form of Sanquiro's composition anchors the opera within its setting. Constable's use of the picturesque, in which he responded critically to English industrialisation and the trail of social changes it left in its wake, would have been a useful model for Sanquirico who, in his scenes for Anna Bolena, is addressing a corrupt, brutal and almost benighted historical event. Futhermore, that Sanquirico looked to England for compositional inspiration seems feasible when Italian landscapes in general were rendered more impressionistically, with realism and naturalism appearing from the mid-nineteenth century. ${ }^{90}$

The light in both Sanquirico's set and Constable's painting falls on the Gothic building and the darkness at the edges of the scenes suggests a shadowy outer realm. The illuminated Gothic exterior of Windsor Castle conveys Sanquirico's particular attention to using light and shade within the painted sets, a practice that declined as theatre lighting grew more sophisticated during the nineteenth century. ${ }^{91}$ In the park scene for Anna Bolena, the lions at the gate have some accuracy, as they are a symbol used on the St George's gate, the main entrance to Windsor Castle. The scenery, informed by the landscape, the building itself, and contemporary English art reveals that Sanquirico (and others involved) considered the accuracy of the location essential to the opera, and that while England may not be presented musically, the country was vividly

\footnotetext{
${ }^{90}$ J. H. Rubin, 'Realism' in Grove Art Online, Oxford Art Online, http://oxfordartonline.com/subscriber/article/grove/art/T070996, (12 February 2009).

${ }_{91}^{91}$ Viale Ferrero, 'Stage and Set', p. 14; David Kimbell, Italian Opera, Cambridge: Cambridge University Press, 1991, p. 410.
} 
illustrated on stage.

The staging becomes more visually Gothic as the opera progresses. In much the same way as the music, propelled by the plot and the turn of events for Anna, can also be interpreted in this way. Anna, and her ladies in waiting (the women's chorus) reflect the Queen's increasingly Gothic plight: betrayed by men and incarcerated in the Tower of London, she is beset by madness waiting for her execution amongst the foreboding pointed arches (figure 1.4).

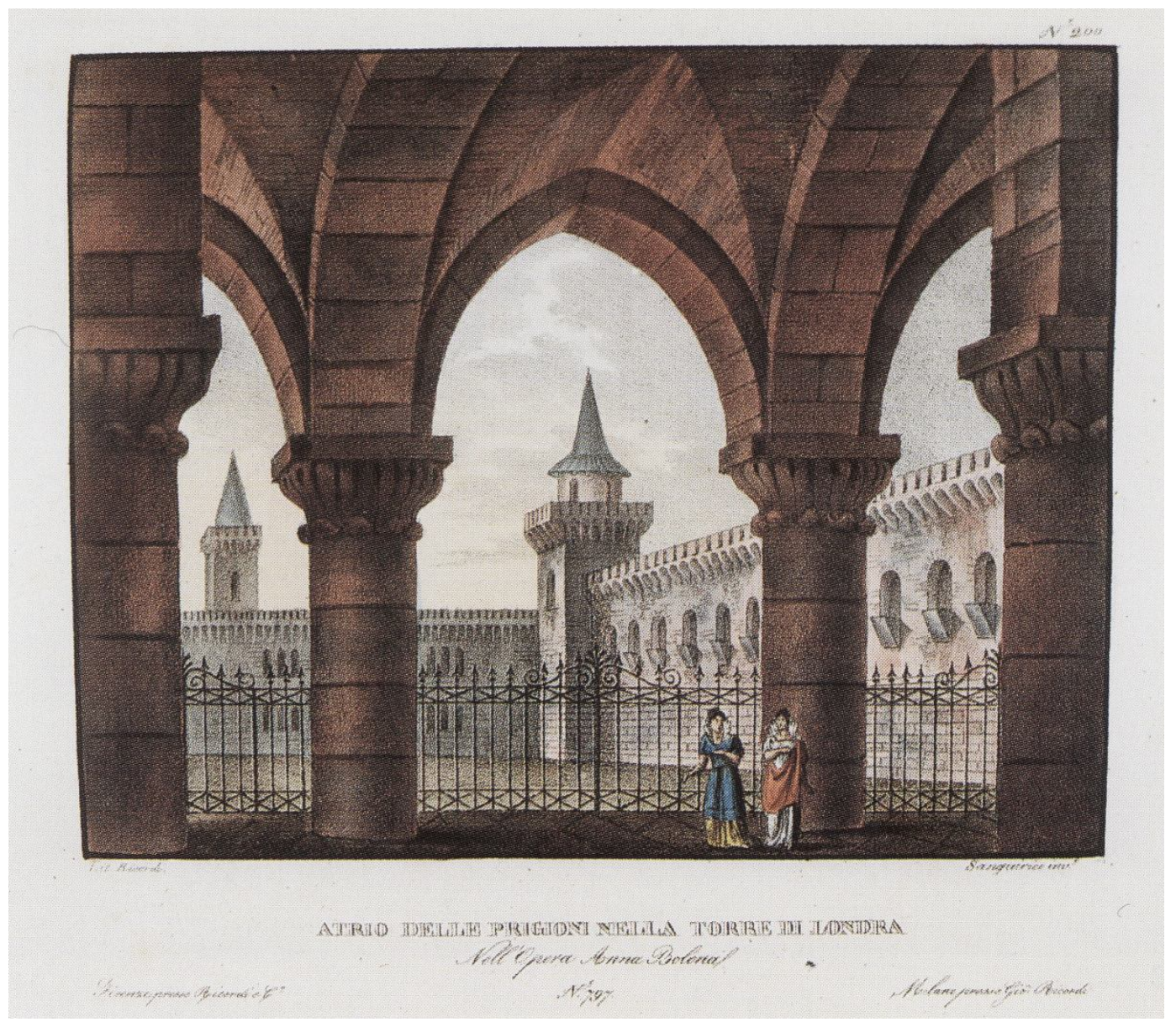

Figure 1.4: 'Atrio delle prigioni nella Torre di Londra', Alessandro Sanquirico, stage design for Act 2, scene 3 of Donizetti's Anna Bolena ( Milan, Teatre Carcano, 1830.) ${ }^{92}$

${ }^{92}$ In Le Prime Representazione delle opere di Donizetti Bini and Commons label this as Act 3, scene 3. However, Black has translated the Cammarano's staging outline for Anna Bolena, and as Act 2, scene 3 (or, as Cammarano calls it, scene 6 - he does not begin at scene 1 in Act 2, but scene 4) as 'Hall in the prison of the Tower of London - four side doors leading to various prison cells'. Anna Bolena has no Act 3. See Bini and Commons, p. V; Black, The Italian Romantic Libretto, p. 275. 
The Tower of London is an example of medieval Norman architecture and much of the interest surrounding the Tower in the nineteenth century involved remodelling it in keeping with its original style, and demolishing sections that did not conform to medieval style. The battlements and semicircular windows are a feature of Norman architecture, and are strongly represented in the various buildings of the Tower. In the scenery for Act 2 of Anna Bolena, the most prominent feature is the Norman pillars, topped with Gothic arches. Their size dwarfs the performers and the arches' position at the front of the stage allows the rest of the scene to fade into the perspective, thus pushing the visual Gothic to the fore. In true English fashion, the sky is a noticeably gloomy grey from the end of Act 1, reflecting both the setting and the mood of the opera. This is particularly apparent when compared with the other sets Sanquirico designed. In the first scenes of Pacini's Classically-inspired L'Ultimo giorno di Pompeii (1825) blue sky prevails, even surrounding a billowing Vesuvius before it erupts in Act 2. For Donizetti's comic opera L'elisir d'amore, Sanquirico also provides blue skies throughout. There seems to be a general correspondence between gloomy skies and more Gothic subjects, as Bellini’s Il pirata (also 1827) transpires beneath Sanquirico's stormy sky. ${ }^{93}$

Presumably the costuming for Anna Bolena underwent the same rigorous 'authenticity' checks as for the ballets. As Viale Ferrero and Franchi indicate, an essential reason for keeping costume sketches of past productions was to then be able to cross-reference information with new works set in close temporal or locational proximity.

\footnotetext{
${ }^{93}$ Alessandro Sanquirico Stage Sets for Operas and Ballets as Produced at La Scala, Milan: Ricordi, 1840.
} 


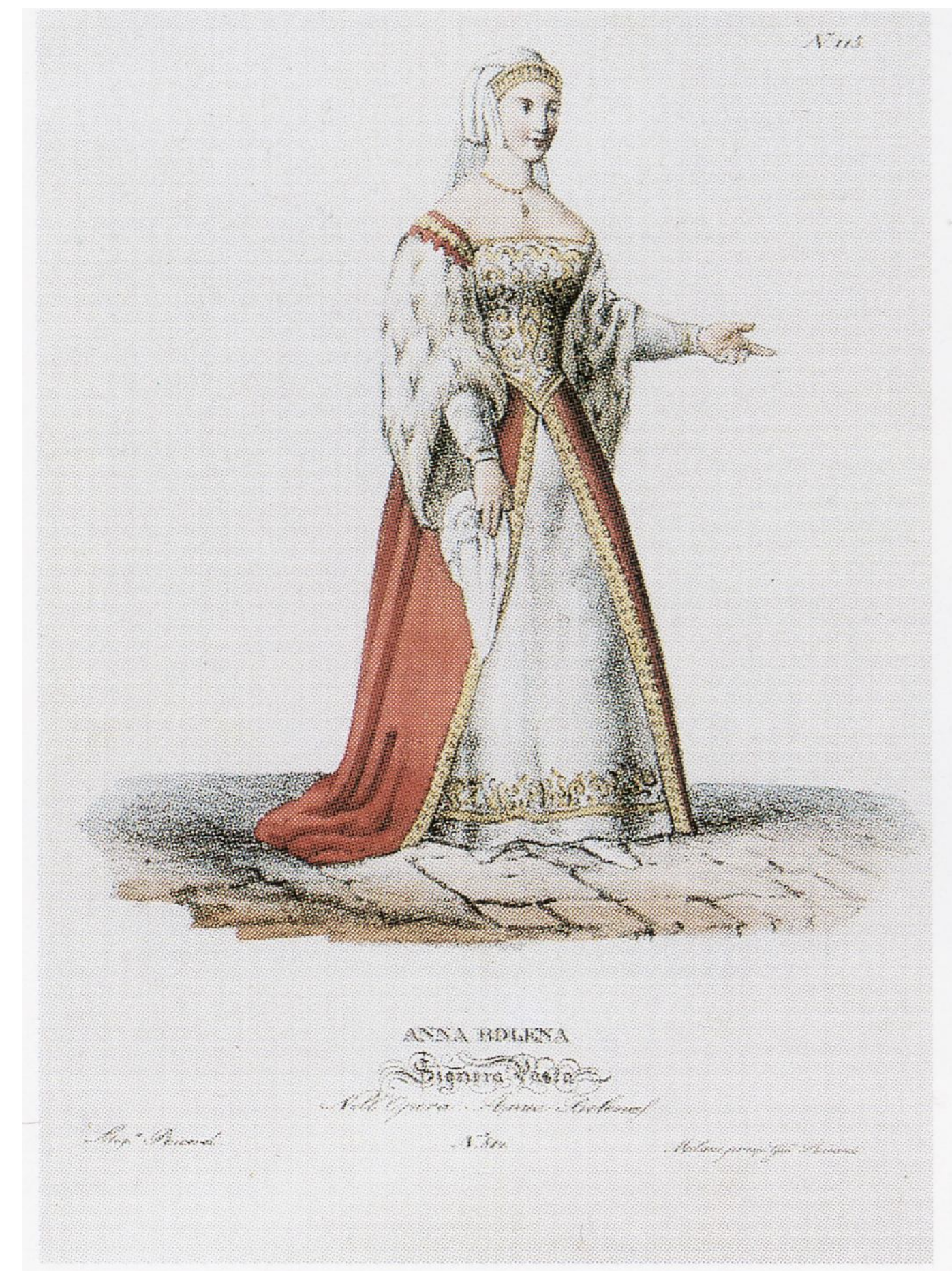

Figure 1.5: Alessandro Sanquirico, costume for Anna in Donizetti's Anna Bolena ( Milan, Teatre Carcano, 1830). 


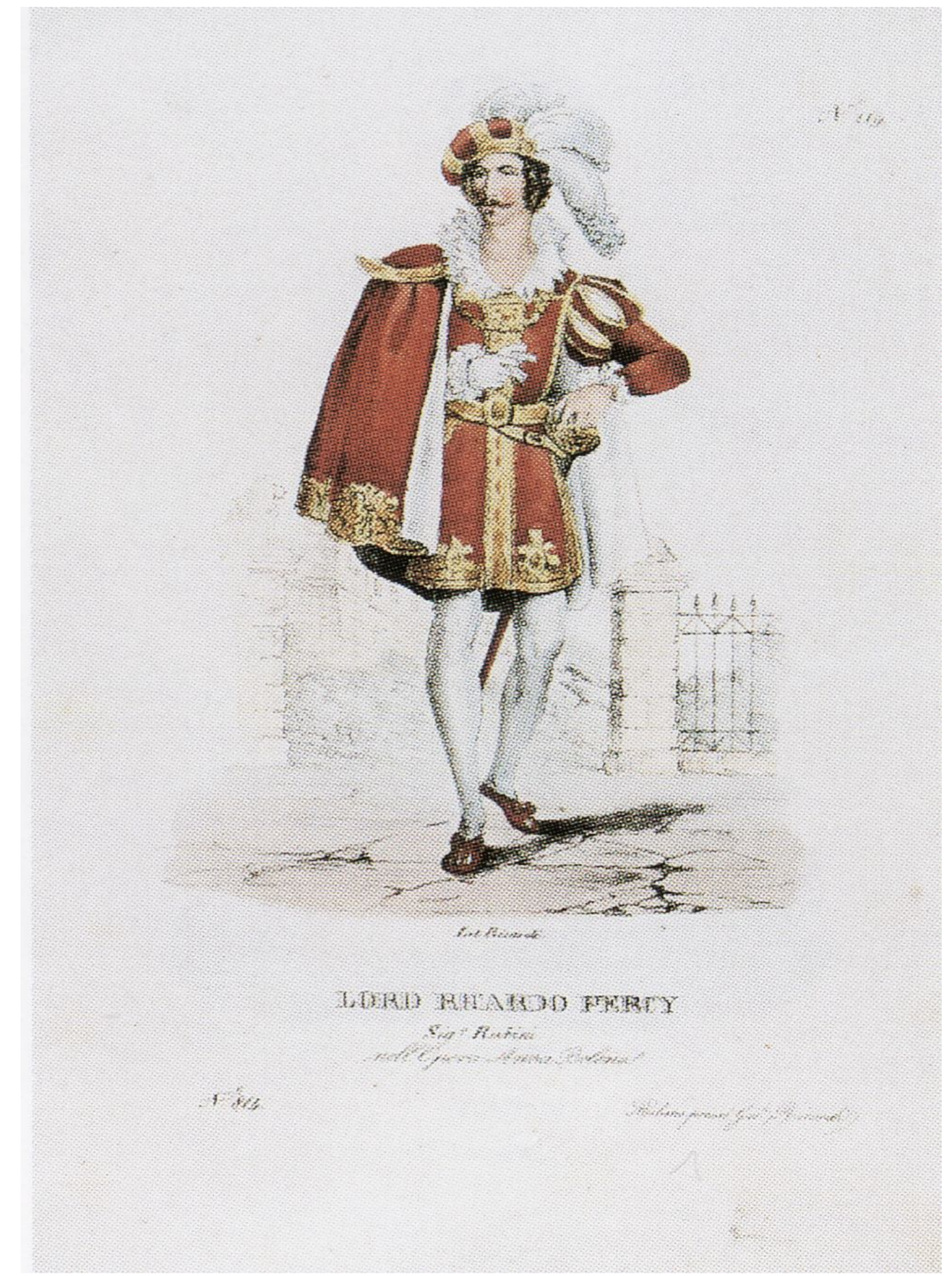

Figure 1.6: Alessandro Sanquirico, costume for Percy in Donizetti's Anna Bolena ( Milan, Teatre Carcano, 1830). 
The costumes for Anna Bolena and Percy are respectively described by Cammarano as 'a rich court dress with train, crown with short headbands' and 'loosefitting coat, cloak, knitted stockings and a hat with feathers' (figures 1.5 and 1.6). ${ }^{94}$ Anna is to wear a plain dress for the prison scene. In many respects, the costumes appear to show their time, rather than belonging to a specific place, and it is only in comparing other costumes from 'northern' works that a consistent style can be observed. Percy's costume is not dissimilar from Filippo Cerrone's design for Buondelmonte. By the time the censors refused to allow the performance of Maria Stuarda, the sets and costumes appear to have already been completed, for Ashbrook describes that when an alternative story about Lady Jane Grey was suggested, its merit was that the historical English sets and costumes would still be suitable. ${ }^{95}$ Therefore the sets and costumes intended for Maria Stuarda may well have been reused for its premiere as Buondelmonte, despite the action's shift to Florence. Thus the gold, red and white colour scheme, with ornate patterns around the hem, sleeves and neck would suggest English royalty; and the particularly bushy plumes on the hats of the men would appear to be a feature used frequently to present England (and Scotland): A large plume is seen atop the hat of a male costume for Gaetano Gioja's ballet of Kenilworth, based on Scott, of course. ${ }^{96}$ Costumes for Roberto Devereux also sport plumed hats. This is not to say that this style of hat was not used in other operas, but the sheer size of these 'northern plumes' makes them noticeable. Additionally, the characters given these elaborate hats are often royalty or nobility.

\footnotetext{
${ }^{94}$ Black, The Italian Romantic Libretto, p. 273.

95 Ashbrook, Donizetti and his Operas, pp. 86-7.

${ }^{96}$ Viale Ferrero and Franchi, 'Costume Designs by Alessandro Sanquirico and Others for Ballets Performed at the Teatro alla Scala, p. 38.
} 


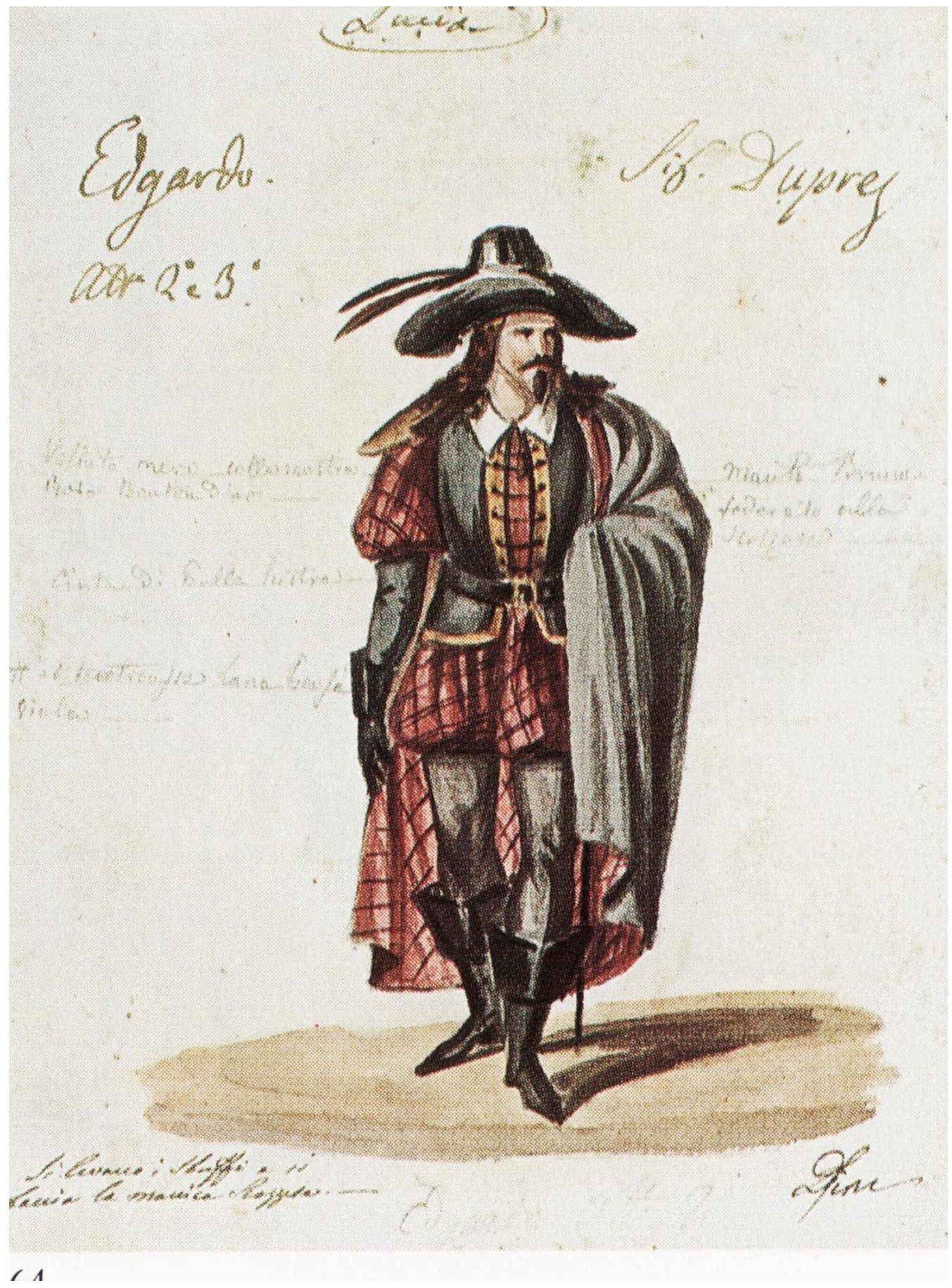

Figure 1.7: Filippo Peroni, costume for Edgardo in Donizetti's Lucia di Lammermoor (Naples, Teatro san Carlo, 1835). 


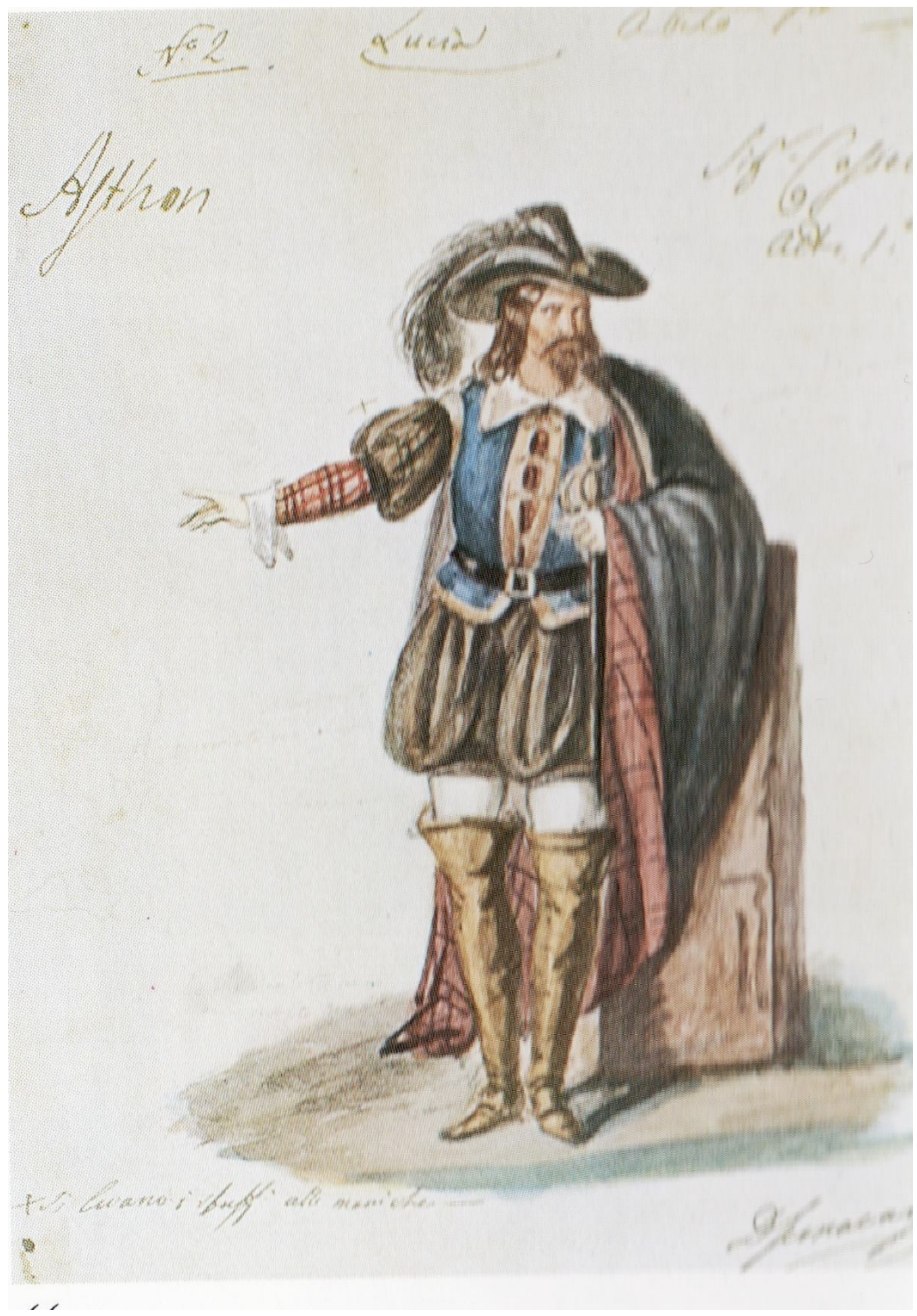

Figure 1.8: Filippo Peroni, costume for Enrico in Donizetti's Lucia di Lammermoor (Naples, Teatro san Carlo, 1835). 


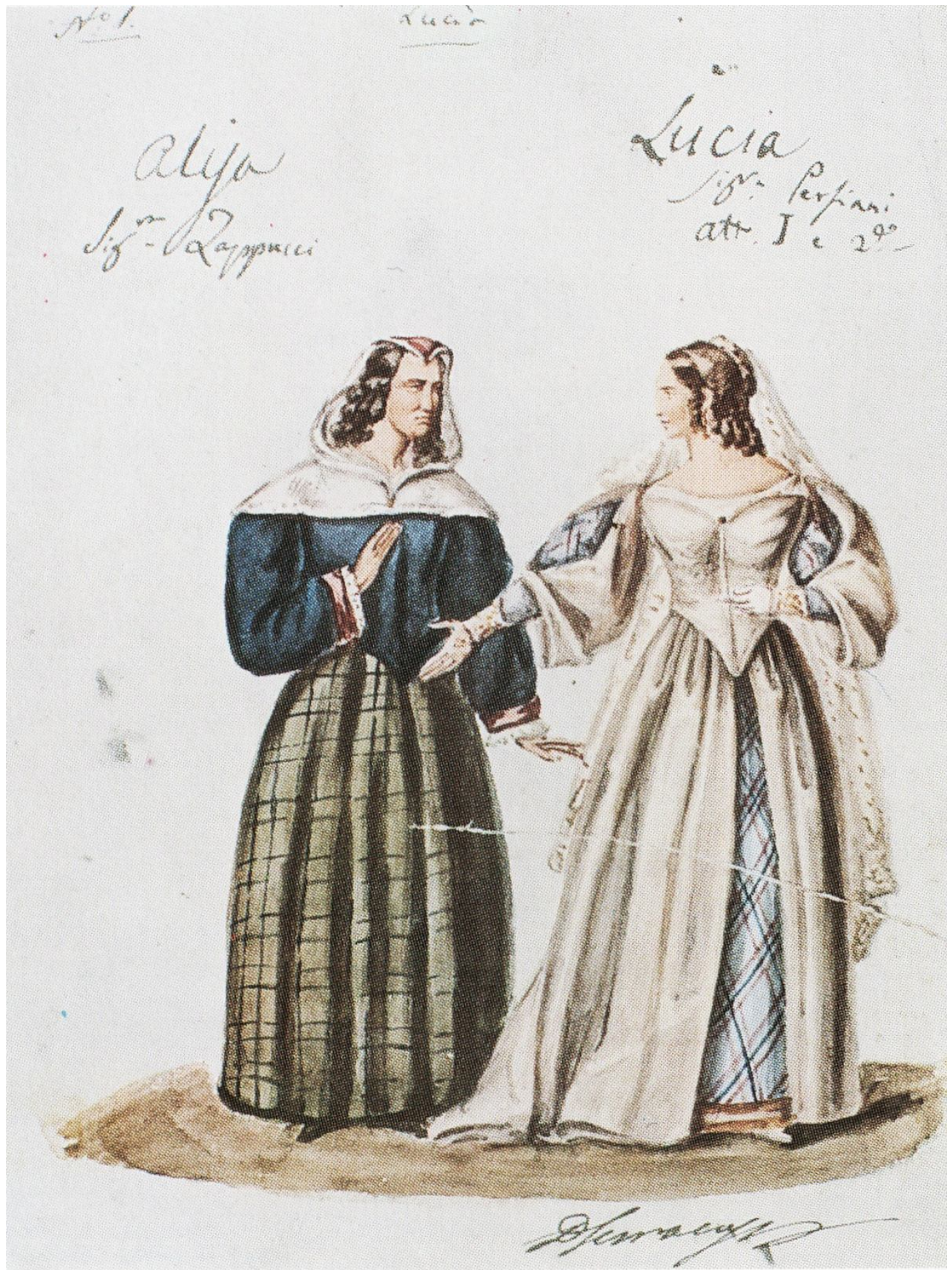

15

Figure 1.9 Filippo Peroni, costume for Alisa (left) and Lucia (right) in Donizetti's Lucia di Lammermoor (Naples, Teatro san Carlo, 1835). 
It is significant that Edgardo's two-feathered embellishment is outshone by Enrico's superior plume when Edgardo is cast as the sole remaining Ravenswood heir, downtrodden by the Ashtons (figures 1.7 and 1.8). In Roberto Devereux, the Duke and Duchess of Nottingham wear the same colours and trims, as do the Queen and the Duke of Essex, in outfits of deep green brocade. The costumes also work to visually align the opera's characters in Anna Bolena. Although the Gothic flavour of Anna Bolena is most apparent in the sets, the costumes also show the marks of 'Englishness' and historical research to situate the music within its 'correctly northern' milieu.

Conveying location was perhaps easier for Cerrone, who was responsible for designing the costumes for Lucia's premiere. Scotland and Scottishness were often represented by tartan in the nineteenth century, much as they are today (figure 1.9). Tartan was worn mainly in the Highlands, but Lucia is set in the Lowlands where the style of dress depended greatly on class and occasion. By the late eighteenth century, fashion plates and magazines showing the latest styles from London and Paris were appearing in Scotland; much of the country was not as isolated in reality as was assumed on the continent, and depicted in the opera. However, most of Donizetti's Italian audience would have been unaware of any Lowland-Highland dress distinctions; and certainly those working in the theatre had no difficulty in exploiting tartan as the most potent symbol of Scotland. Contrary to England's lack of a distinct style - apart from the penchant for 'northern' plumed cavalier hats - for the Scottish, tartan was fundamental to national identity.

For the London premiere, however, Tacchinardi Persiani did not wear tartan, and certainly in Scotland and England wearing tartan had associations Italians were unlikely to be aware of (figure 1.10). In the eighteenth century, tartan itself became contested. 


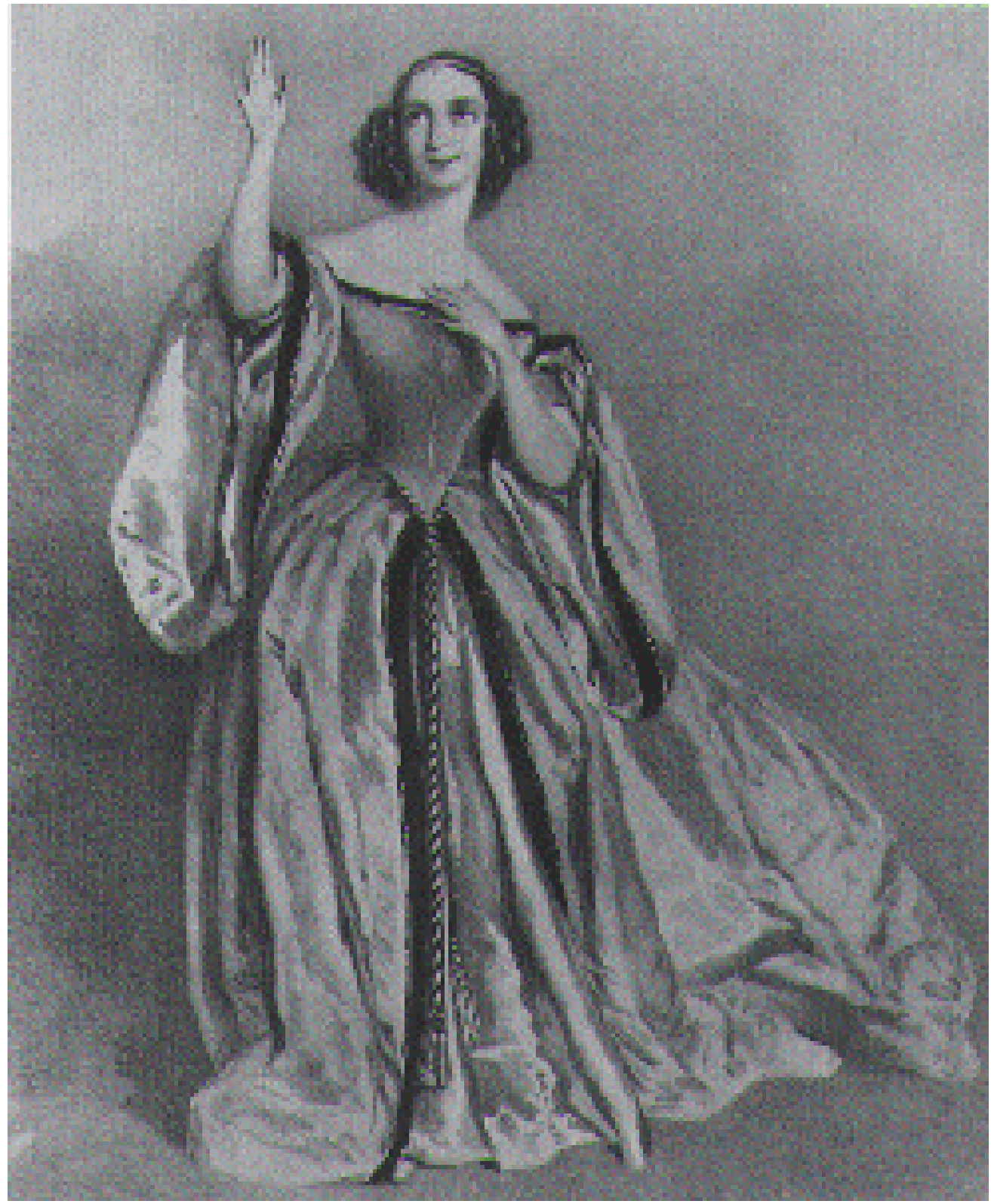

Figure 1.10: Fanny Tacchinardi-Persiani as Lucia at the London Premiere, Her Majesty’s Theatre, 5 April 1838.

The wearing of 'Highland garb', including tartan and kilts, was banned by the Act of Proscription in 1747 as a repercussion of the failed Jacobite uprising of 1745 . The ban lasted for the next thirty-five years and was a heavily felt punishment in the Highlands, 
a Jacobite hotspot and the home of tartan and kilt-wearing. ${ }^{97}$ Kilts evolved into what is familiar today as traditional or 'folk dress', as Naomi Tarrant calls it, in the early nineteenth century and since then have been commonly worn by Highland men (although not always in tartan weave). Before this, it was more common for men and women to wear a significantly longer length of fabric, called a plaid, which was worn in place of an overcoat around the chest and across the shoulders before being gathered 'kilt style' around the waist. ${ }^{98}$ Tarrant explains that 'Lowlanders saw the dress of Highlanders as outlandish because it did not conform to their idea of what was proper'. This followed on from the generally accepted view in the eighteenth century that Highlanders were barbaric and primitive, and matters were not helped by the series of measures put in place to curb violent clan conflicts, where the first response to a disagreement was to reach for a sword. ${ }^{99}$ England and the Lowland Scots hoped to maintain order and peace, which in effect meant stripping the Highlanders of their own cultural practices.

\footnotetext{
${ }^{97}$ The wording of the act, detailing what was not to be worn and the punishment: '.. from and after the first day of August, one thousand seven hundred and forty seven, no man or boy, within that part of Great Britain called Scotland...shall on any pretence whatsoever, wear or put on the clothes commonly called Highland Clothes (that is to say) the plaid, philibeg, or little kilt, trowse, shoulder belts, or any part whatsoever of what peculiarly belongs to the highland garb; and that no tartan, or partly-coloured plaid or stuff shall be used for great coats, or for upper coats; and if any such person shall presume, after the said first day of August, to wear or put on the aforesaid garments or any part of them...shall suffer imprisonment, without bail, during the space of six months, and no longer; and being convicted for a second offence...shall be liable to be transported to any of his Majesty's plantations beyond the seas, there to remain for a space of seven years.' Quoted in John Struther, The history of Scotland from the union to the abolition of the heritable jurisdictions in MDCCXLVII: to which is subjoined a review of ecclesiastical affairs, the progress of society, the state of the arts, \& co. Blackie, Fullarton \& co., 1828, p. 515.

${ }^{98}$ See Naomi Tarrant, “dress", The Oxford Companion to Scottish History, Oxford University Press, 2007 in Oxford Reference Online.

http://www.oxfordreference.com/views/ENTRY.html?subview=Main\&entry=t246.e85, (22 May 2009).

${ }_{99}$ The beginnings of these peace-promoting measures came in response to the first failed Jacobite uprising of 1715, and included passing disarming Acts in 1716 and 1725.
} 


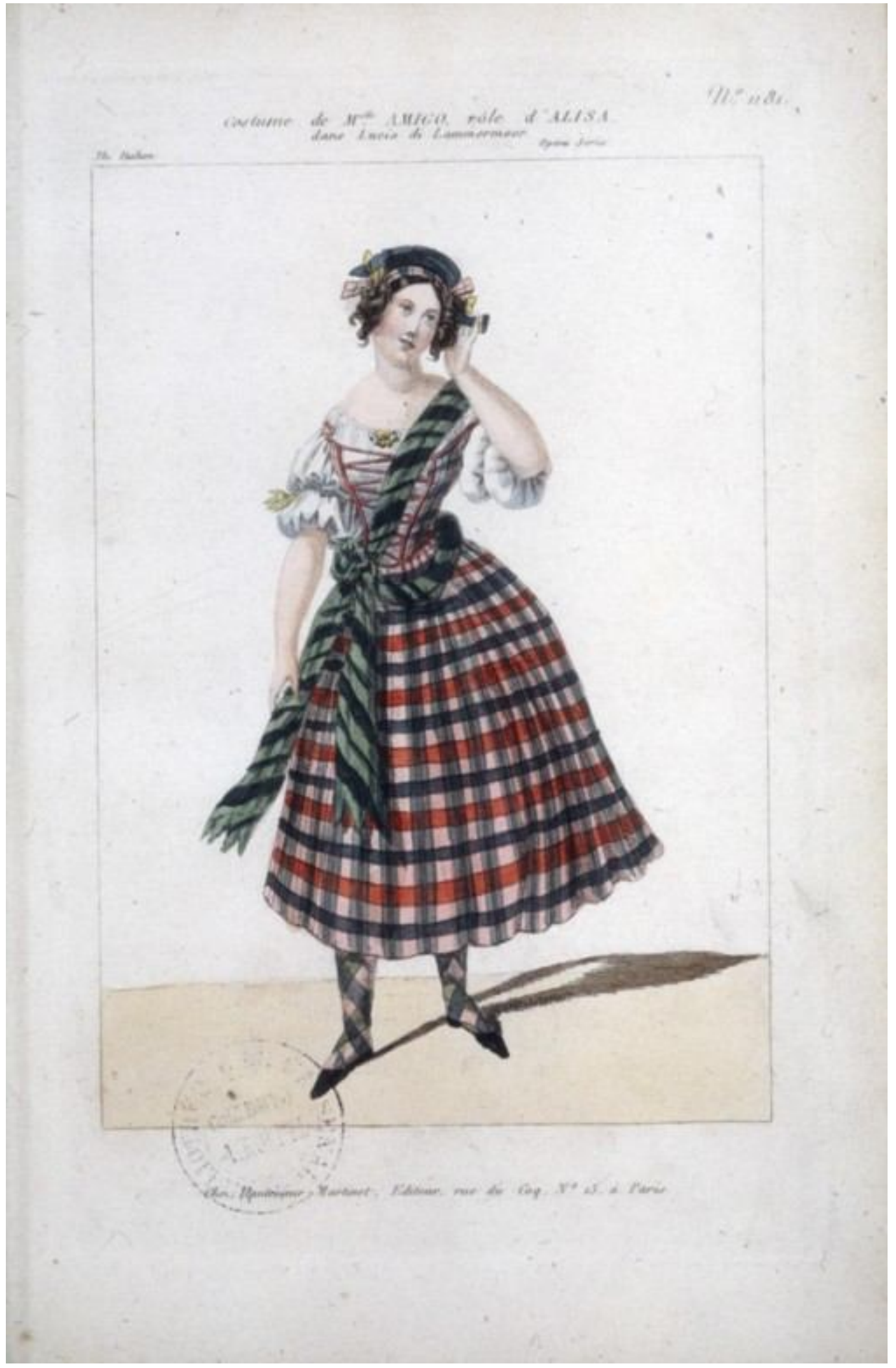

Figure 1.11: Costume for Alisa in Donizetti's Lucia di Lammermoor (Paris, Thêâtre-Italien, 1837). 


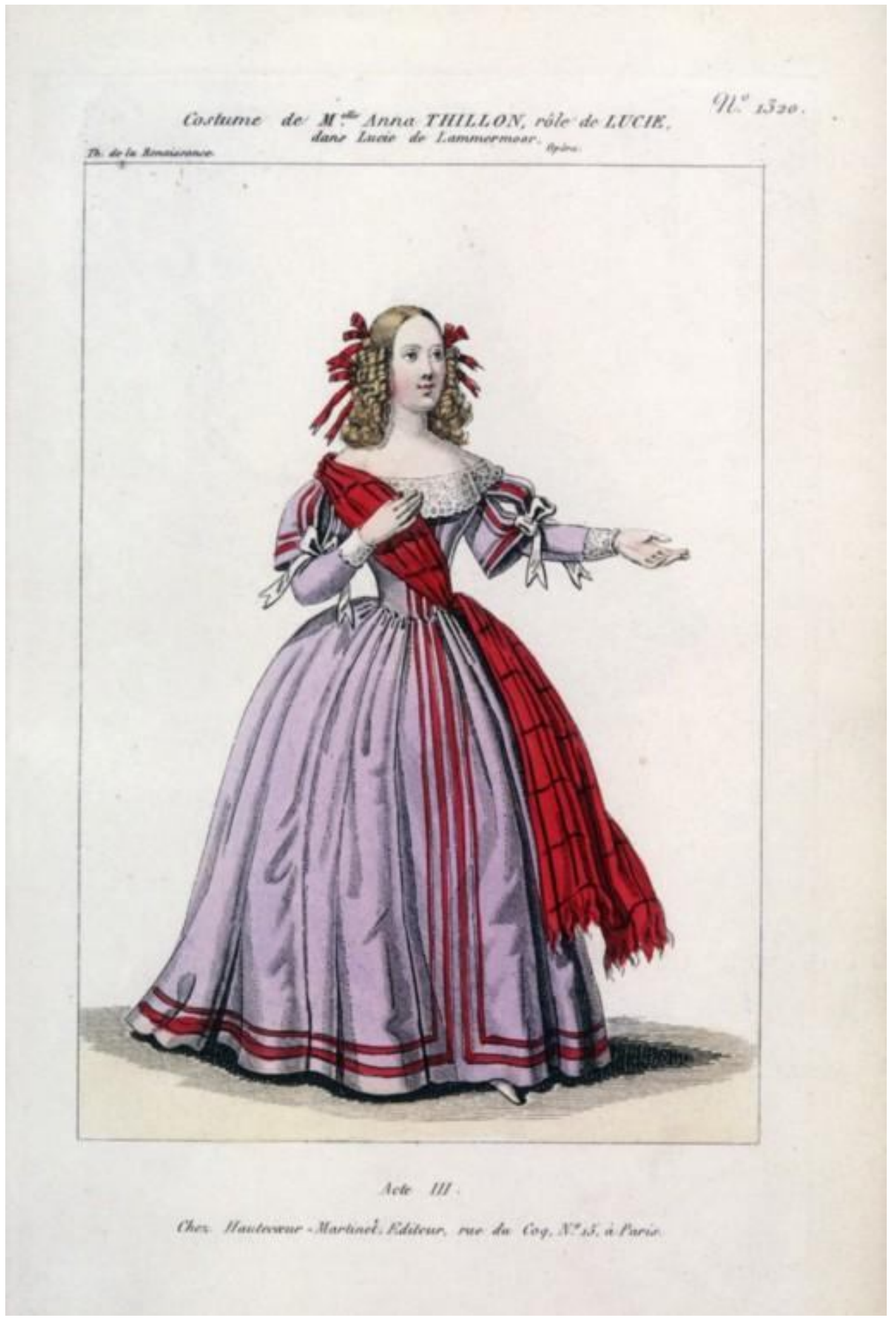

Figure 1.12: Hautecouer Herménégilde, costume for Lucie in Act 3 of Donizetti's Lucie de Lammermoor (Paris, Théâtre de la Renaissance, 1839). 


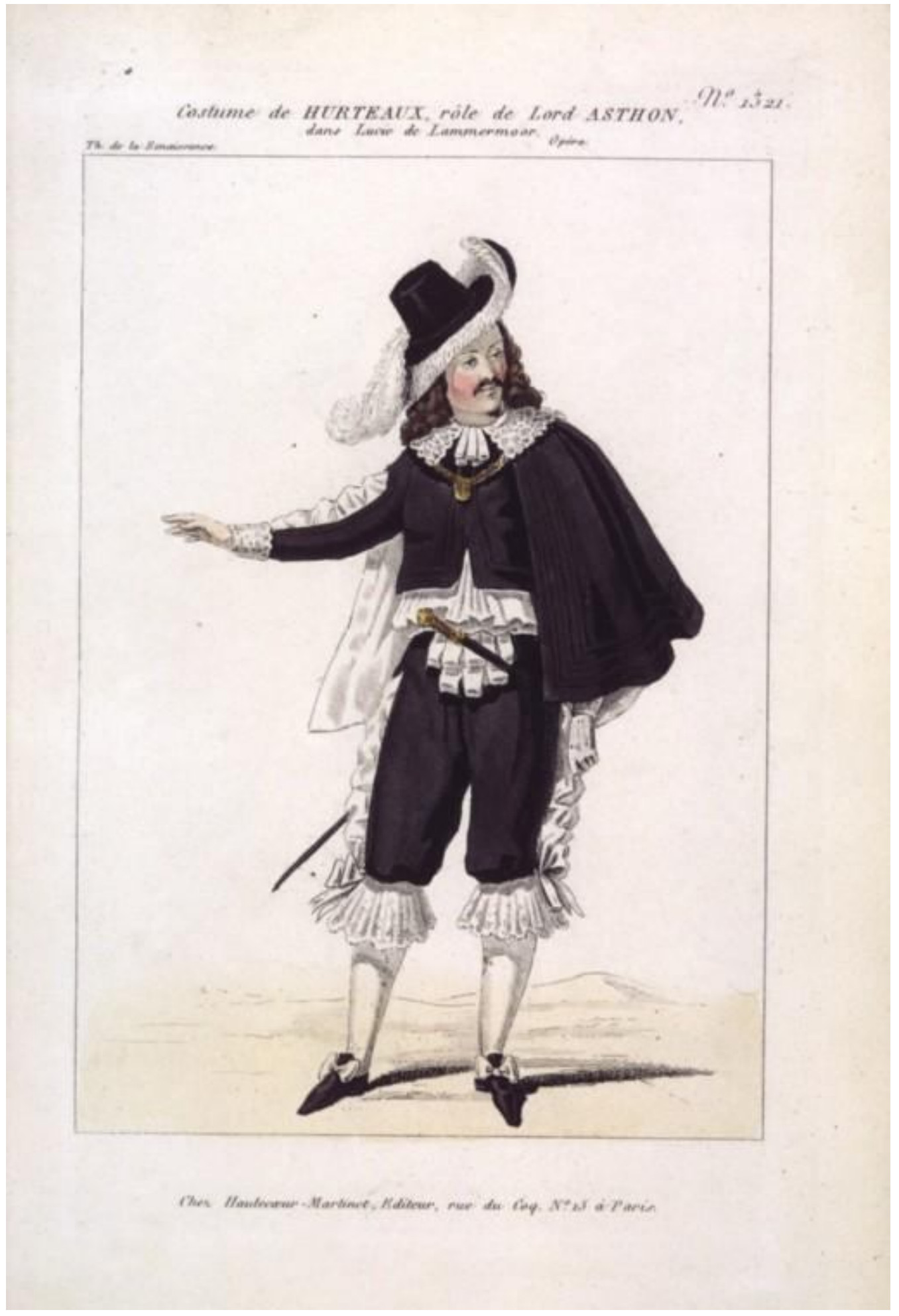

Figure 1.13: Hautecouer Herménégilde, costume for Lucie in Act 3 of Donizetti's Lucie de Lammermoor (Paris, Théâtre de la Renaissance, 1839). 
In spite of the ban on all things Highland, those who did break the law were seen as nationalistic martyrs and, after the Act was abolished in 1782, tartan in particular became reinvented as a popular sign of national pride for both Lowlanders and Highlanders. It became acceptable, even fashionable, to wear it in small amounts. Thus the stylised amalgamation of the more 'respectable' dress of the Lowlanders (in line with much of Europe and appropriate for the stage) and its tartan trims and linings may not have looked peculiar in the original production of Lucia to the audience. However, during the period in which the opera is set, it would have been unusual.

For the French premiere at the Théâtre-Italien, Alisa loudly projects her nationality (figure 1.11). She sports a dress, plaid and stockings, each in a different tartan, which is finished with a tartan-trimmed Tam o'Shanter. Lucie and Edgardo's dress, seen in a later production of the French adaptation, limit the 'Scottish' features of the costuming to a tartan plaid for Lucie. Enrico, displaying no cultural symbols, could be an aristocrat from anywhere, although his cavalier hat and plume persist (figures 1.12 and 1.13).

All these bolts of tartan without a doubt situate the action in Scotland. The location of Lucia is infinitely more explicit through costuming alone than either Anna Bolena or Roberto Devereux. Yet a Gothic mood fails to resonate in any of these costumes. It is in fact the costumes that come later in Anna, and, to a far greater extent, in Lucia which overtly illustrate the Gothic. These costumes, of course, are the 'plain dress' of Anna, and Lucia's blood-splattered gown. To represent the Gothic scenario as a deep-set association or product of Scottish culture, Donizetti uses a cheerful Scottish style at dramatically superficial moments to musically construct his setting. In the same way, the costumes are visually superficial, acting to amalgamate the Scottish people and therefore Scotland itself - with the Gothic scenery and landscape. The costumes 
demonstrate that the Gothic originates from these tartan-clad characters, their voices echoing myriad superstitions and deplorable familial control. The physicality of Lucia's voice expressing her distress at the fountain or eventually succumbing to her brother's command while dressed in her tartan costume joins the Gothic and Scottish contexts together inseparably. By the time she enters, after murdering Arturo, grotesquely stained in his blood, it is but a small step from Scottish maiden to mad murderess.

In his instructions for the staging that appeared in the libretto for Lucia's premiere, Cammarano explains how her entrance in Act 3 is to occur:

Lucia e in succinta è bianca veste: ha le chiome scarmigliate, ed il suo volto, coperto da uno squallore di morte, la rende simile ad uno spettro, anzicché ad una creatura vivente. II di lei sguardo impietrito, i moti convulsi, e fino un sorriso malaugurato manifestano non solo una spaventevole demenza, ma ben anco $i$ segni di una vita, che già volge al suo termine.

[Lucia is wearing a scanty white garment: her hair is dishevelled and her face, being covered by a deathly pallor, makes her look more like a ghost than a living person. Her expressionless gaze, her convulsive movements and even her stony smile indicate not only a fearful insanity, but also the signs of life already moving towards its end. $]^{100}$

Mary Ann Smart notes that this ensemble of dishevelled hair and white nightgown recalls Shakepeare's Ophelia and images of madwomen in the nineteenth century; and insanity is, of course, a prominent feature across the Gothic-operatic continuum. ${ }^{101}$ Lucia's attire also symbolises a break of social decorum much like Ophelia's. Lucia wears a garment intended only for the private space of the bedroom, but in a socially inappropriate move, enters into a public scene. Lucia's gown visually evokes her voice, which is splattered with bursts of extreme coloratura, and thus is an inappropriate display. As the visual oddity in a ballroom scene of lavishly attired wedding guests, all

\footnotetext{
${ }^{100}$ Black, The Italian Romantic Libretto, p. 289.

${ }^{101}$ Mary Ann Smart, 'The Silencing of Lucia', Cambridge Opera Journal, Vol. 4, No. 2 (July, 1992), p. 125.
} 
eyes are drawn to Lucia, and all ears to her voice. Lucia is still at this point undoubtedly surrounded by the tartan of her guests, which enforces the locale. But in her mad scene, Lucia's Gothic episode casts an enormous shadow over the opera and her appearance emphatically promulgates Scotland's permanent shift in the opera to a dark, violent and irrational place, which continues in Edgardo's suicidal finale. The cheerful reception festivities are thereby abandoned, overwhelmed by Scottish Gothicism. ${ }^{102}$ When Donizetti sets Scotland to music, he thus at first merges the cheerful and dark sides of the country, both musically and visually, but finally he 'uncovers' Scotland, and unearths its true, Romantic form. Although there are strong Gothic episodes earlier in the opera - most prominently Lucia's cavatina - her dress here remains Scottish (tartan) and the music and text (and Lucia's gesture and expression) are heavily responsible for portraying the Gothic. However, Lucia's dress in the cavatina does not evoke the Gothic as vividly as does her bloody gown does in the mad scene, although the earlier outfit still acts in connecting the Scottish with the Gothic. In this earlier scene, as in much of the opera, Gothic Scotland is illustrated by the landscape.

From Cammarano's descriptions of the scenery for other northern operas, including Mercadante's 1843 opera Il reggente, it is clear that Scotland was depicted as Gothic in Lucia. For Il reggente, based on Scribe's libretto Gustave III, (set by Auber in 1833) Cammarano moved the action from Sweden to Scotland, where he obviously felt its themes of supernaturalism and corruption were fitting. ${ }^{103}$

\footnotetext{
102 Whether Lucia is still holding the sgian dubh she uses to murder Arturo can heighten the feeling in the audience that Lucia is both dangerous and fragile in her deranged state, as well as marking the scene as Scottish.

${ }^{103}$ Scribe's libretto was also the basis for Antonio Somma's libretto for Verdi, Un ballo in maschera. In this later opera (1859) the setting is Boston.
} 


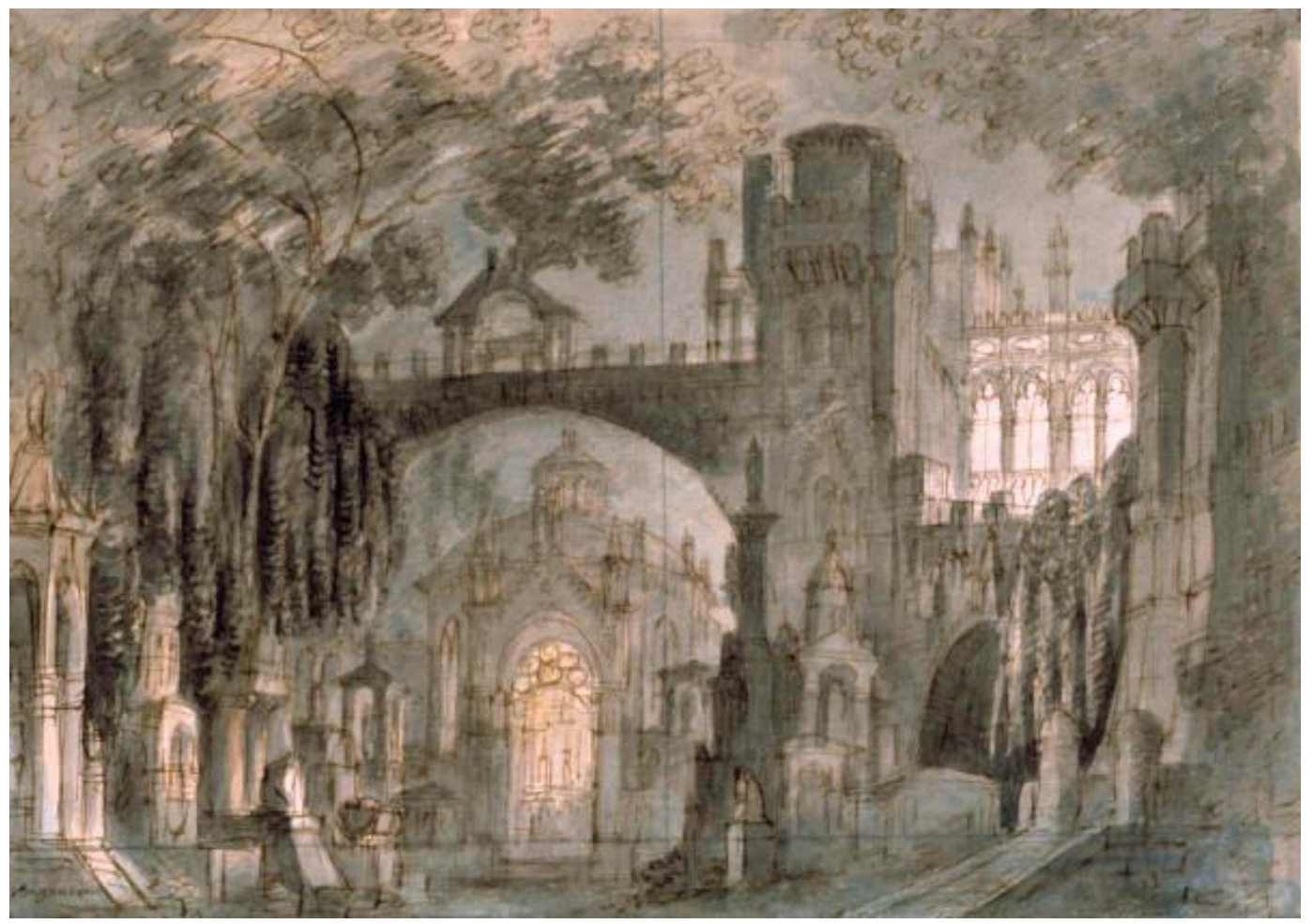

Figure 1.14: Francesco Bagnara's set design for Act 3, scene 3 of Donizetti's Lucia di Lammermoor (Venice, Teatro La Fenice, 1844).

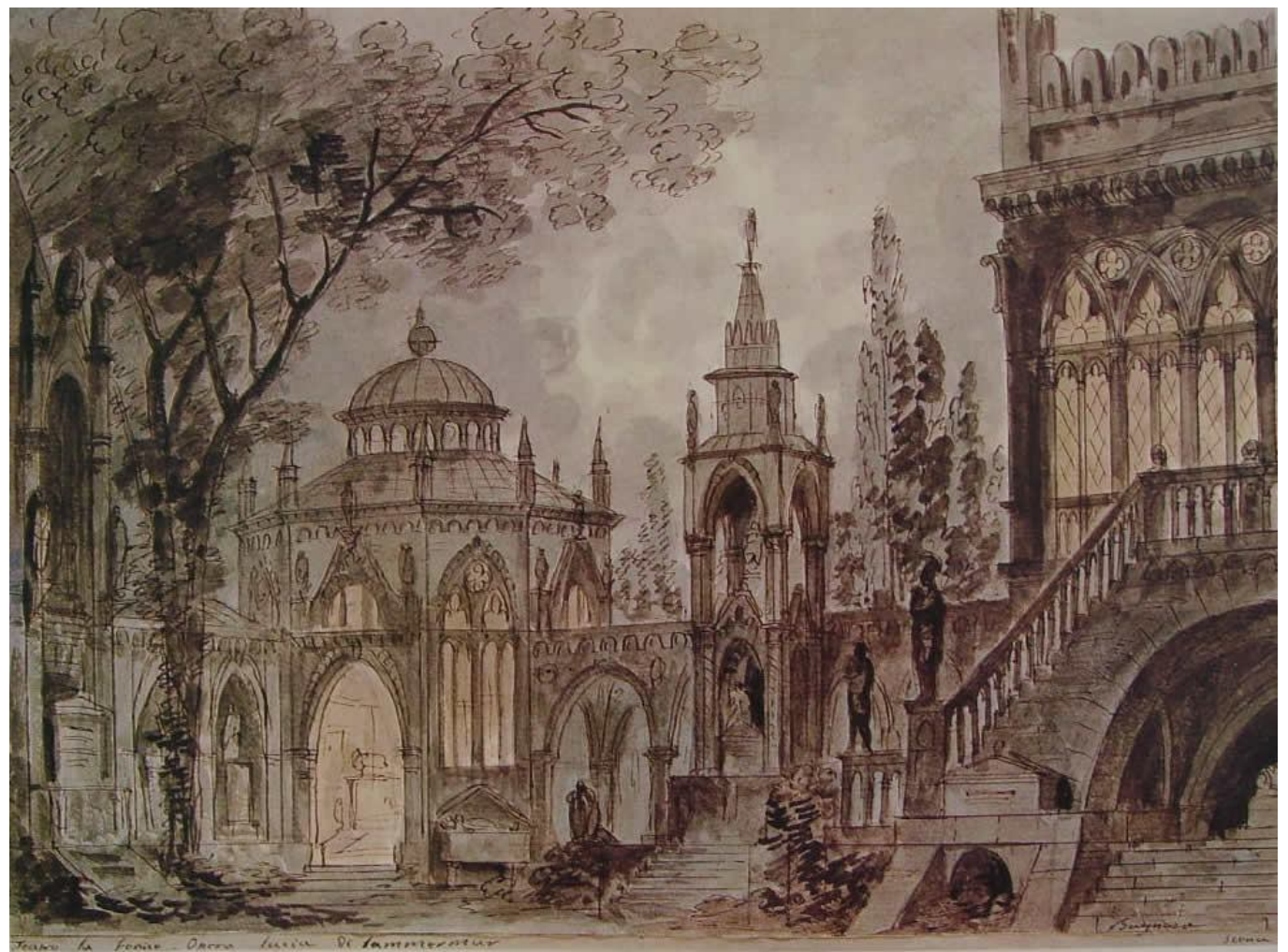

Figure 1.15: Francesco Bagnara's set design for Act 3, scene 3 of Donizetti's Lucia di Lammermoor (Venice, Teatro La Fenice, 1844). 
Cammarano's instructions for the scenery outline precisely the Gothic element in both interior and exterior settings. ${ }^{104}$ Inside, 'the habitation of a fortune-teller' for Act 1, scene 3 illustrates darkness, secrecy and primitiveness:

...on the right a fireplace with a cauldron on a tripod: a few torches burn around the room; on one side, the entrance to another room: on the opposite side, a secret entrance at the top of a small flight of steps: the door is at the back and a window, through which can be seen the gates of Edinburgh.

Act 2, scene 1 reveals Cammarano's Romantic vision of Scotland's landscape:

A wild place on the outskirts of Edinburgh: at the back, in a valley formed from the bare rock, can be seen the burial ground of those condemned to the extreme penalty; a little way off is the winding river: the sky is covered with thick clouds, which move in the wind, now showing, now hiding the moon.

His imagination aligns with almost every representation of Scotland in the nineteenth century: darkness, rugged terrain, temperamental weather, and a graveyard - the ultimate Gothic site. A place of the condemned, enveloped in gloom is also the setting for the uncannily cheery aria Roberto sings in Roberto Devereux, 'Bagnato il sen di lagrime’:

Horrible prison in the Tower of London, intended for the last dwelling place of guilty people condemned to death: it is illuminated by a little gloomy light which finds a way in through a window fashioned high up in the wall, and secured with great bars of iron: a closed door on one side. ${ }^{105}$

This last description is what would be expected of the Tower of London, but the image of an actual prison when compared with how Scotland is presented is remarkably similar. Therefore the scenery of these operas, along with Lucia, highlights the Gothic intrigue of the north.

The scenery designed for an 1844 production of Lucia at La Fenice in Venice was by Francesco Bagnara, who was the scenographer at the theatre between 1820 and 1839. Two scenes remain - presumably both depicting the Act 3 finale which shows the

\footnotetext{
${ }^{104}$ Black, The Italian Romantic Libretto, p. 286.

105 Ibid, p. 285.
} 
Gothic Ravenswood castle (figure 1.14). The second example (figure 1.15) seems to show the front of the castle, rather than the back, and the instructions in the libretto note say that Edgardo and Enrico are to meet near the Ravenswood ancestral tombs, which is where Edgardo subsequently stabs himself. It is unlikely to be an earlier scene, unless for this production the Wolfscrag scene was moved outside, as all of Acts 2 and 3 until the finale take place within either the Ashbrook's building or Ravenswood castle tower. The darkness of the scenes suggests it would not have been the opening hunting scene, and the fountain scene is set in parkland and is therefore also unlikely. I would suggest that it is the graveyard of the scene that is pivotal. In figure 1.15 , the tombstones are absent, and as a potent Gothic symbol representing the ancient family line and the preoccupation with death, it must be shown in the scene. The instructions in the libretto also note that the lights of the castle can be seen in the background of the opera's finale and there are unmistakable parallels between the compositions of the two scenes.

That Bagnara seems to have revised his scenery to make it more Gothic (and to follow the librettist's instructions) demonstrates the importance of the visual elements in Lucia's setting. The scenery is the one component of the opera that encourages the opera's Gothicism consistently throughout. Despite the fact that Lucia's cavatina is set in parkland, it is reminiscent of the second scene in Anna Bolena, where the Gothic construction is entwined with the natural setting. A partially-ruined fountain is the most conspicuous feature of the scene, from which Lucia has witnessed the ghost of a woman rise. The Wolfscrag scene at the beginning of Act 3 would surely have depicted the scene in Scott's text: Wolfscrag, the newly destitute Edgardo's ruined castle, is perched on the edge of a cliff under a stormy sky. ${ }^{106}$ In Opera on stage, Viale Ferrero makes a distinction between remains and ruins. Remains are 'vestiges of passing time', rather

${ }^{106}$ Scott, The Bride of Lammermoor, p. 59. 
than ruins, which are 'the result of a present act of destruction'. Remains 'expressed greater metaphorical, picturesque and archaeological content. In Lucia these three values are united in the "fountain once covered by a fine edifice decorated with all the friezes of Gothic architecture, and now surrounded by the debris of this edifice". ${ }^{107}$ These associations of remains are also endemic to the Gothic, with the picturesque denoting the imperfections in a non-utopian landscape that looks towards the rustic, intense or turbulent side of nature. As Viale Fererro suggests, the unnatural, man-made fountain is a remain. The embellishments, in suitable Gothic fashion, have crumbled away - and the fountain is archaeological because of its construction in times long past. The metaphorical side is somewhat more complicated, but can be read as symbolic of Lucia's own crumbling demise.

In Metaphysical Song, Gary Tomlinson shows how the landscape can function both metaphorically and metaphysically in opera. His focus on Gothic scenes, including the Wolfs Glen scene in Weber's Der Freischütz is particularly notable. Tomlinson's framework for exploring internal realms and the subconscious, the dialect between Abbatean distinctions of noumenal and phenomenal sounds, will be considered in later parts of this study. Here though, Tomlinson's application of the noumenal onto the landscape of opera has compelling implications for the Gothic, its bond with Scotland and the north and how landscape works within opera as a whole. Tomlinson refutes the notion that Romanticised nature in opera reflects the emotional state of the character and instead suggests that 'a new distance between humanity and nature that arises from the post-Kantian breakdown of confidence in the transparency of empirical reality to our knowledge'. ${ }^{108}$ Thereby the Gothic landscape is layered internally, an

\footnotetext{
${ }^{107}$ Viale Ferrero, 'Stage and Set', p. 46.

${ }^{108}$ Gary Tomlinson, Metaphysical Song: An Essay on Opera, Princeton: Princeton University Press, 1999, p. 105.
} 
outcrop of the characters' subconscious imaginations. The landscape itself becomes a cause of the Gothic scenario, and through this Tomlinson's suggestive exploration of the landscape further resounds in a type of Scottish-Gothic similitude.

Through exploring the characters' response to their Gothic landscape and their insistent Gothic imaginations, the music works in conjunction with the visuals and text. The connection between a northern locale and the Gothic is built from Donizetti's placement of 'Scottish' musical mannerisms within the chorus numbers. This reinforces the unity of Scotland and the Gothic without disturbing the over-arching tragic Gothic mood. What is more, Tomlinson's idea recalls Senici's conclusion that the voice of nature must be envoiced by the characters who live within the landscape and thus invoke their surroundings through their own music. ${ }^{109}$ Lucia herself has a fundamental role as a means of expressing the Gothic in Donizetti's opera, which becomes the focus of the next chapter.

${ }^{109}$ Senici, Landscape and Gender in Italian Opera, p. 19. 


\title{
Chapter Two: ‘Heroines', Hallucination, and Hysteria
}

\author{
Gothic Women
}

There she sees a damsel bright,

Drest in a silken robe of white;

Her neck, her feet, her arms were bare,

And the jewels disordered in her hair.

I guess t'was frightful there to see

A lady so richly clad as she -

Beautiful exceedingly! ${ }^{1}$

Christabel's first glimpse of Geraldine, the anthropomorphic supernatural being in

Coleridge's 'Christabel', resonates with the last time Lucia enters the stage in

Donizetti's Lucia di Lammermoor for her celebrated mad scene. Geraldine is a form of exquisite beauty, and her silk gown and jewels deceive Christabel of her nobility.

However, Lucia's white gown is smeared with her husband's blood and her dishevelled hair provides a sharp contrast with her formal (often tartan trimmed) dress of the previous Act. While, to the naïve Christabel, Geraldine's 'frightful' appearance seems out of place in the Gothic forest setting, the surroundings do not diminish Geraldine's beauty, which is in fact a corporeal façade of the other-worldly. Rather, Christabel is enthralled in much the same way that Lucia's voice enthrals her audience in her mad scene. Yet Coleridge's visual depiction of Geraldine suggests something sinister to the reader from the outset: that the Gothic setting this 'woman' appears in presages eventual doom for Christabel. In Lucia too, there are unmistakable visual and musical omens of

\footnotetext{
${ }^{1}$ Samuel Taylor Coleridge, 'Christabel', in Coleridge's Poetry and Prose, edited by Nicholas Halmi, Paul Magnuson and Raimonda Modiano, New York: Norton, 2004, p. 164, 11. 60-6.
} 
the heroine's demise from the outset, especially in her cavatina. There is a correlation between Geraldine's diabolical guise and Lucia's deranged appearance as visual gestures of the other-worldly. Madness is an other-worldly realm into which Lucia enters, while the supernatural enters into the physical realm from an other-worldly sphere. Madness and the supernatural are both integral parts of the Gothic, and both are inextricable from the female characters. ${ }^{2}$ Therefore, the focus of this chapter becomes how operatic heroines assert opera's place within the Gothic tradition.

Senici's argument that the soprano communicates the setting through her established nationality holds true for Donizetti's Lucia. The prima donna is fundamental in identifying Scotland with the Gothic because of her visual and musical surroundings. Lucia not only acts as the link between the two, but also is as important as the setting in determining how the Gothic genre itself is determined and constructed in opera. Every axis of the Gothic in opera passes through the central female character: the supernatural, madness, ancestral lineage, imprisonment, oppression, betrayal, murder, death. Part of Lucia's susceptibility to the Gothic lies in constructed views of Scotland and women as exotic 'others' in the Gothic as well as the operatic. Lucia personifies Scotland extra-visually because she is a representation of the irrational 'other' through her actions. The phantom that Lucia sees at the fountain appears to her alone, singling her out as irrational as her abstract supernatural encounter is unverifiable. In her mad scene, not only is her mind disturbed, but she has lost any shred of logic and sanity. Her mind roams free of the physical world that the other characters inhabit on stage, for instead of interacting with people, she can only interact with her own memory. In both scenes, her mind reaches into her subconscious - to

\footnotetext{
${ }^{2}$ In the 2008 Metropolitan Opera production of Lucia di Lammermoor directed by Mary Zimmerman, the ghost Lucia envisions appears on stage - a 'real' ghost - wearing a long white dress, further associating the supernatural with Lucia and her altered state of mind, and heightening the Gothic mood.
} 
recall her hallucination and her memory - in order to project her imaginings aloud.

During the first of these two pivotal Gothic episodes, her tale remains directed at Alisa, rather than as a pure display of unreason. Additionally, interpreting the work as Scottish-Gothic depends on extra-musical signifiers of 'otherness', which to a presumably rational audience is manifest in Lucia's actions and her simultaneous reflection and embodying of her Scottish-Gothic landscape.

Examining an opera where the northern setting is not as musically explicit as it is in Lucia helps to clarify the integral role women play in defining the Gothic context. ${ }^{3}$ In Anna Bolena, the heroine's final moments before her execution are spent shifting in and out of a delirious state. The climax is Anna's response to the betrayal and deception inflicted on her by not only men, but also Giovanna Seymour, one of her own ladies-in-waiting. Anna Bolena is not as Gothic in many respects as Lucia; rather Anna Bolena is part of what Anne Williams would term as 'secondary' Gothic, or Eugenia DeLamotte the 'second circle'. ${ }^{4}$ For while Anna Bolena is built around a number of Gothic themes and is set in a medieval castle and prison, basing an opera on historical events instead of a literary work is perhaps less conducive to overt Gothicism, although at the same time, it portrays the emphasis on history as a fundamental dimension of the Gothic. Anna herself, as the 'other', evokes a particularly intense Gothic mood at the end of Donizetti's opera as she is driven mad by her imprisonment and impending

\footnotetext{
${ }^{3}$ There are no dances with local colour in Anna Bolena as there are in Luica, where the music is used for celebration and spectacle. The chorus music in Anna Bolena does little to alleviate the tragic plot unfolding. While there are plenty of examples of dotted rhythms and sequencing in the music, including in the choruses, they are such a prominent musical feature that without taking into consideration a number's context and function within the opera as a whole, they cannot be construed as couleur locale. A musical 'Englishness' is alluded to in only brief passages, rather than the more prolonged examples of 'Scottishness' presented in Lucia.

${ }^{4}$ Williams, Anne. Art of Darkness: A Poetics of Gothic. Chicago: Chicago University Press, 1995, p. 16; Eugenia C. DeLamotte, Perils of the Night: a Feminist Study of Nineteenth-Century Gothic, Oxford: Oxford University Press, 1990, p. 5.
} 
execution. What is most remarkable in Anna Bolena is Anna's interaction with the other characters on stage - she responds to her name and to 'queen' with bouts of lucidity - and has an awareness of her mental states even if she is unable to control them.

Though Anna's entrance in the final scene is announced by an inverted snap rhythm in a last regal gesture, the prevailing Gothicism in this opera is one of mood rather than setting, or a potent combination of both, as found in Lucia. Even before Anna's death, her place is usurped by the king's marriage to Giovanna Seymour, proclaimed by ringing bells. Anna's rapidly moving mental state is not only indicated by the chorus's utterances, but also by Anna herself, in a strange instance of selfawareness. As the final scene opens, the libretto instructs that 'Anna dalla sua prigione. Si presenta in abito tacetenegletto, col capo scoperto si avanza lentamente, assorta in profondi pensieri' ['Anna is in her prison. She wears a ragged dress, with her head uncovered as she advances slowly, deeply absorbed in thought']. In her aria, 'Al dolce guidami', the first of three linked cantabile sections, she tells of a memory. Musically, the finale is striking in the way the music shifts, slipping in and out of an impassioned tone in a reflection of Anna's tussle between sanity and reason. The legato dotted string motive that opens Anna's scena as she recalls her wedding day returns for a second time in the winds, and prefigures the solo flute associated with Lucia's music, alluding to her delicate mind. However, the music becomes agitated as Anna returns to the present. The chorus warns against this inward psychic turn ('O! Memoria funesta!') Anna, partly aware of the chorus's interruption, finds refuge once more in her memory, as the oboe echoes the idyllic country scene of her childhood. The musical underpinning of the libretto conveys that Anna's inward shift is unlike Lucia's five years later, where the tension between Lucia and her accompaniment betray her irrationality. Initially, there is 
no confliction between the sentiments of the libretto and the musical mood accompanying it, nor are there moments when Anna's voice seems to move beyond the orchestral voice as Lucia's. Instead, the music follows her thought patterns, a pendulum between her external and internal worlds.

The impact on her personal musical world comes at the beginning of the ultima scena of the finale as Anna sees and hears the prison guards arrive to escort her to her death. Philip Gossett and William Ashbrook comment that the opening of the finale is the tune of the English composer William Bishop's 'Home Sweet Home' (written in 1821) (examples 2.1 and 2.2). ${ }^{5}$ The tune was part of a book of Sicilian airs, and was also used in Bishop's 1823 opera Clari, significantly subtitled 'the Maid of Milan', and is thus an English representation of Italy as much as an English-composed tune. While the opening of the scena and the air share a step-wise melody and a sometimes-dotted rhythm, these features are common enough that their similar sound may be purely coincidental.

Example 2.1: 'Home Sweet Home', John Bishop.

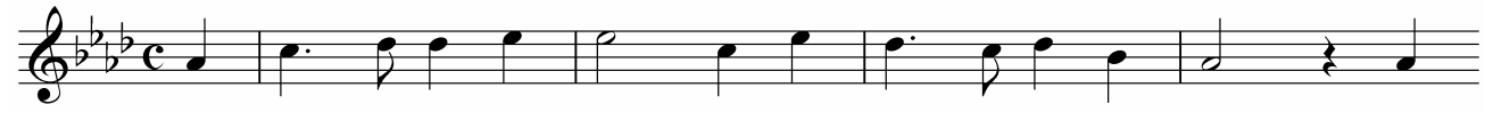

Example 2.2: Entrance of the guards in the Act 2 finale of Donizetti's Anna Bolena, bb. 293-6.

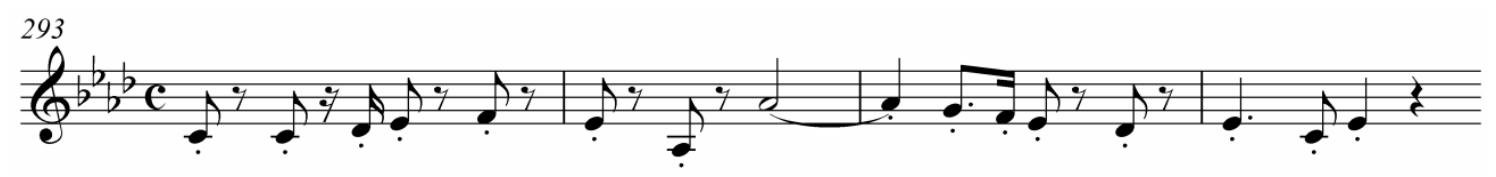

\footnotetext{
${ }^{5}$ William Ashbrook, 'Anna Bolena', in The New Grove Dictionary of Opera, Grove Music Online, Oxford Music Online, http://www.oxfordmusiconline.com/subscriber/article/grove/music/O900144, (2 July 2009); Philip Gossett, 'Anna Bolena' and the Artistic Maturity of Gaetano Donizetti, Oxford: Clarendon Press, 1985, p. 32.
} 
In any case, the music announces the arrival of the royal guards, and if the music was indeed taken directly from Bishop, then Donizetti has altered the pleasant tune for his majestic march.

Example 2.3: Act 2 finale, Donizetti's Anna Bolena, bb.160-8.
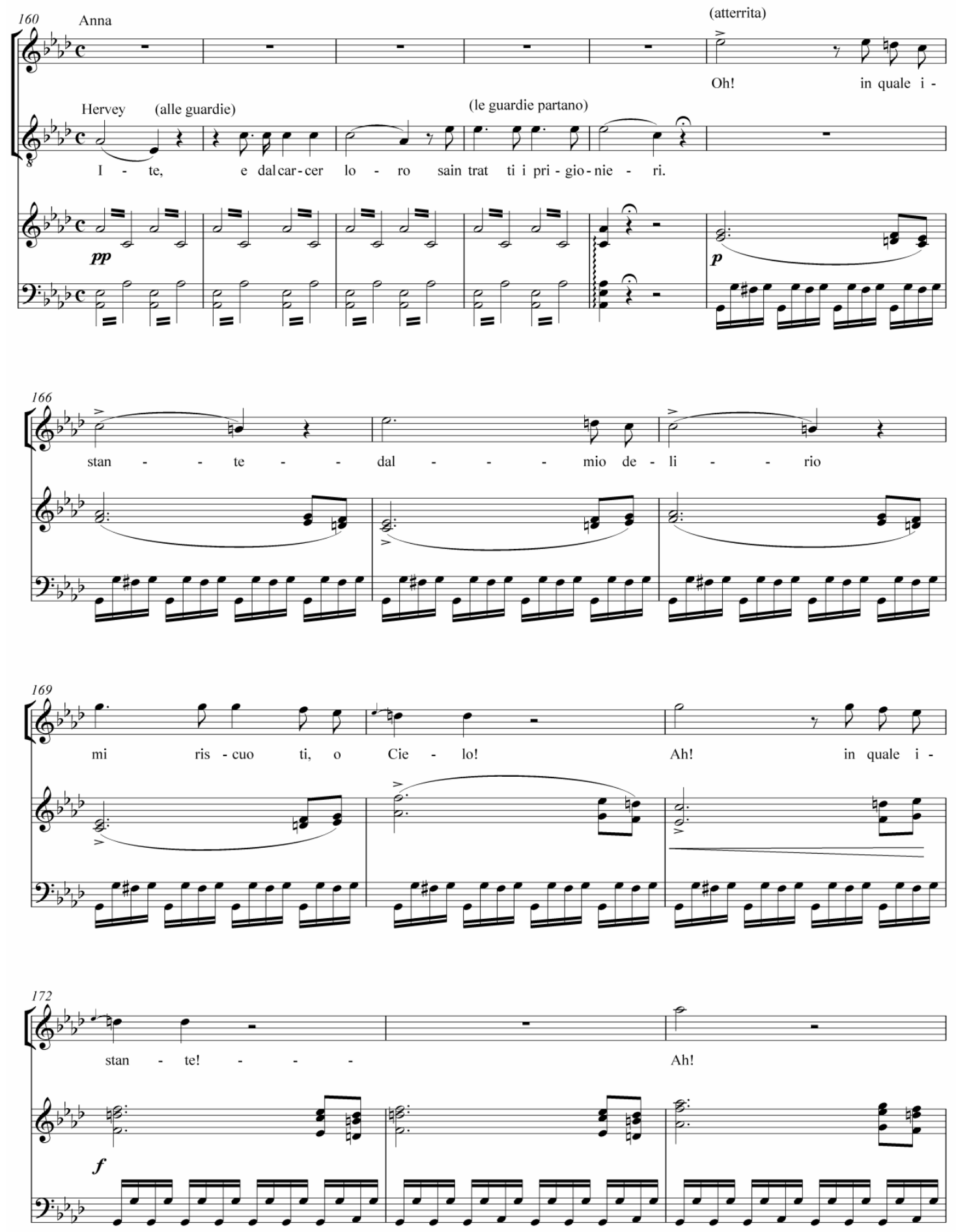


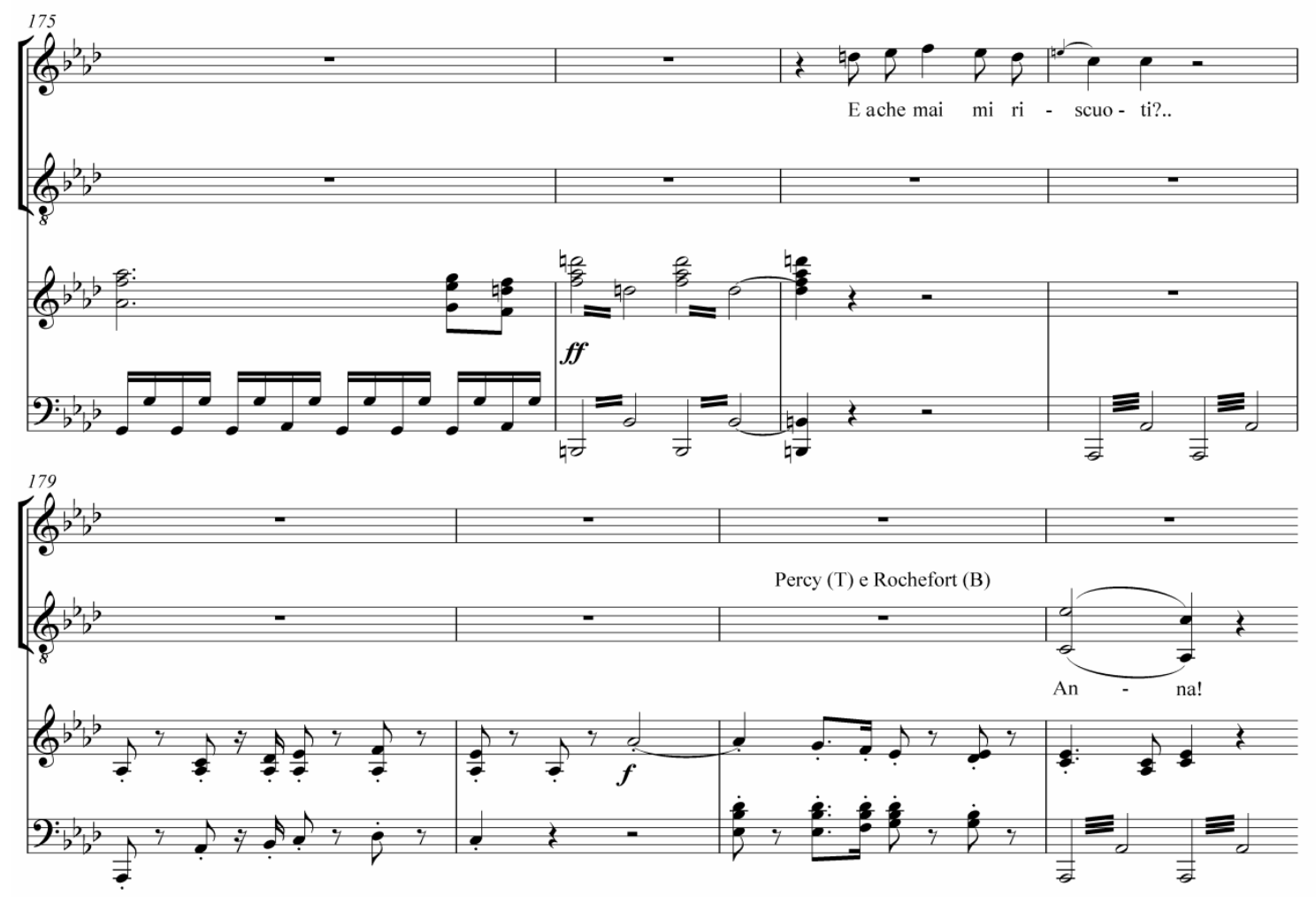

Anna recognises her own irrationality as the guards arrive, ('del mio delirio mi riscuoti, o cielo!' ['rouse me from my delirium, oh heaven!']). After the guards leave, however, Anna swings from their A flat major tune to $\mathrm{C}$ minor for her allegro (Oh! In quale istante') (example 2.3). She pleads to be rescued from her madness, but ironically, it is only the return of the guards who shift the tonal centre back to A flat major briefly before Smeton's entrance causes a series of modulations, which although not uncommon for the scena, emphasises Anna's mental instability. After Smeton confesses to losing his will in the trial, the chorus heralds that Anna is slipping back into derangement ('Ritorna a vaneggiar...delira' ['she reverts to raving.... she is delirious']), as she internalises her thoughts once more. This time though, her thoughts move forward to her looming death in the second cantabile section of the grand finale, 'Cielo a'miei lunghi spasimi'. This aria sees the return of the solo flute as Anna moves - still 
within her delirium - from the frantic to fragile, now resigning herself to her fate, her sobs audible in her appoggiature (example 2.4). Dramatically, Donizetti is at full force here; Anna has barely time to finish her last note (without any extended final ' $A$ ' section) before the wedding festivities are heard. It is only when these drums and bells sound that she is jolted out of delusion and cuts off the chorus when they mention the new queen - 'tacete...cessate' ['quiet...stop']. These festivities are unlike those of Lucia, and do not connote any couleur locale, but hearing their exhilarant sounds, Anna gradually returns to a frantic, crazed state for her final cabaletta.

Example 2.4: 'Cielo a'miei lunghi spasimi', Donizetti's Anna Bolena, bb. 246-57.

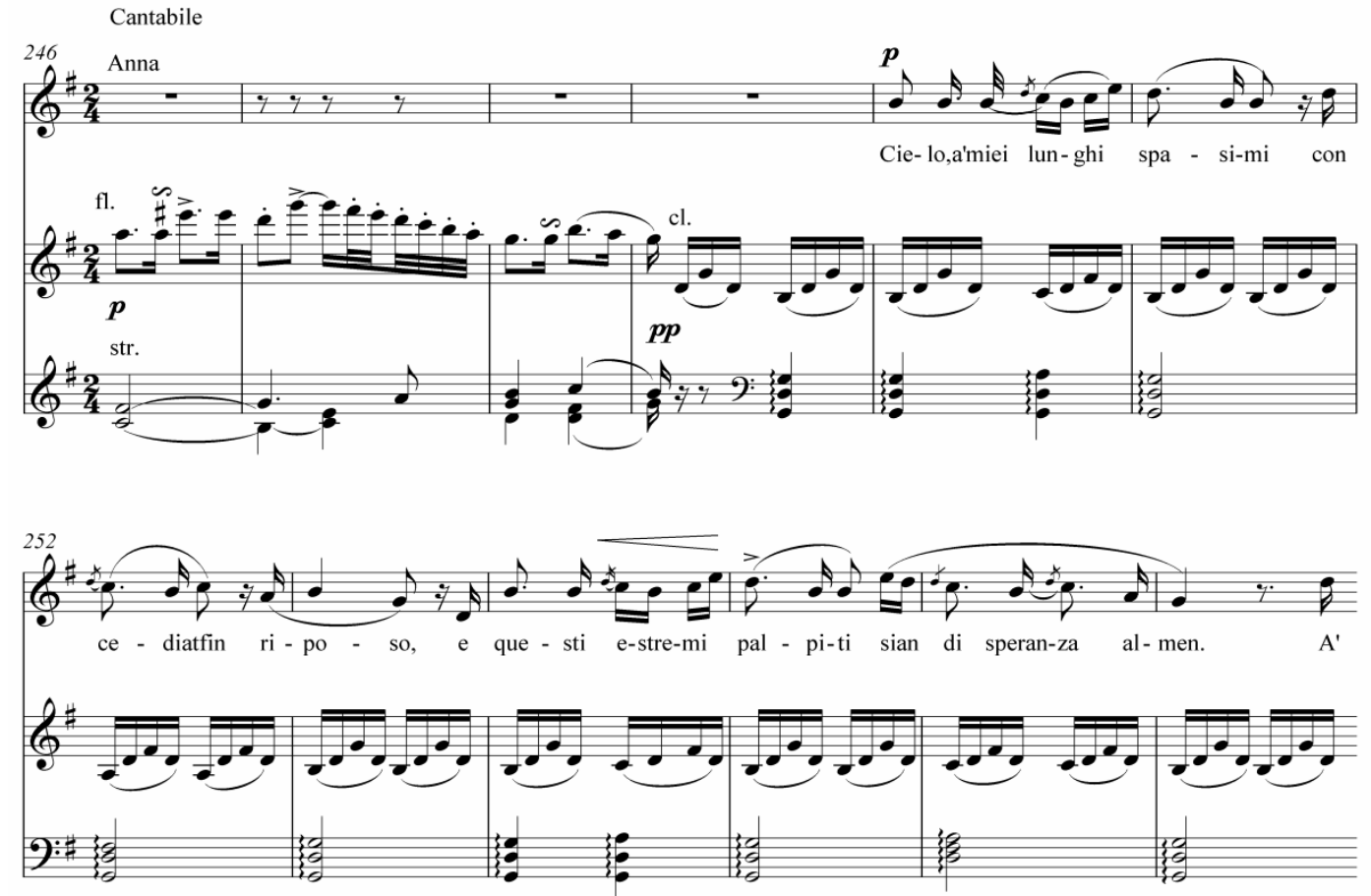


Example 2.5: 'Coppia iniqua', Donizetti’s Anna Bolena, bb. 361-88.
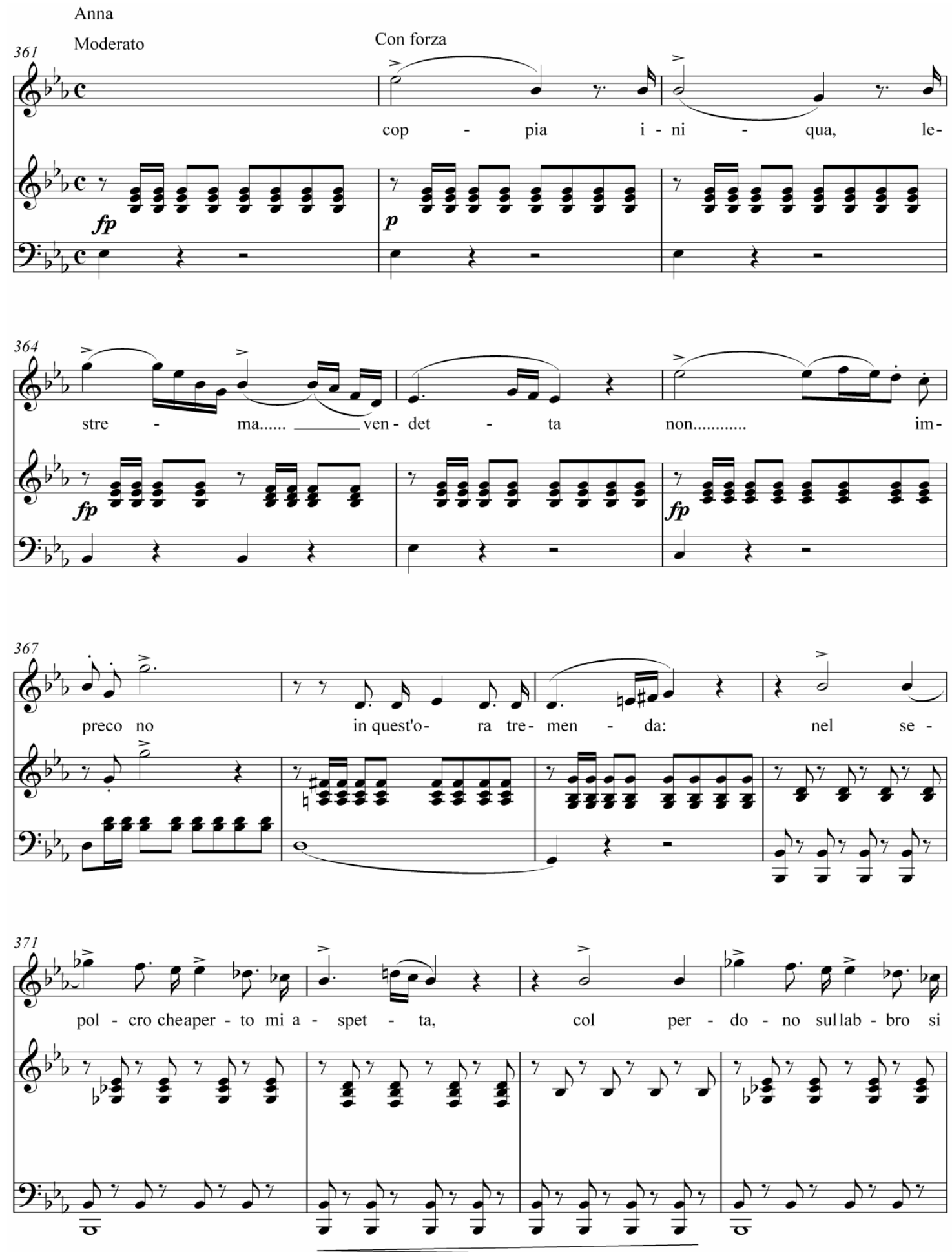


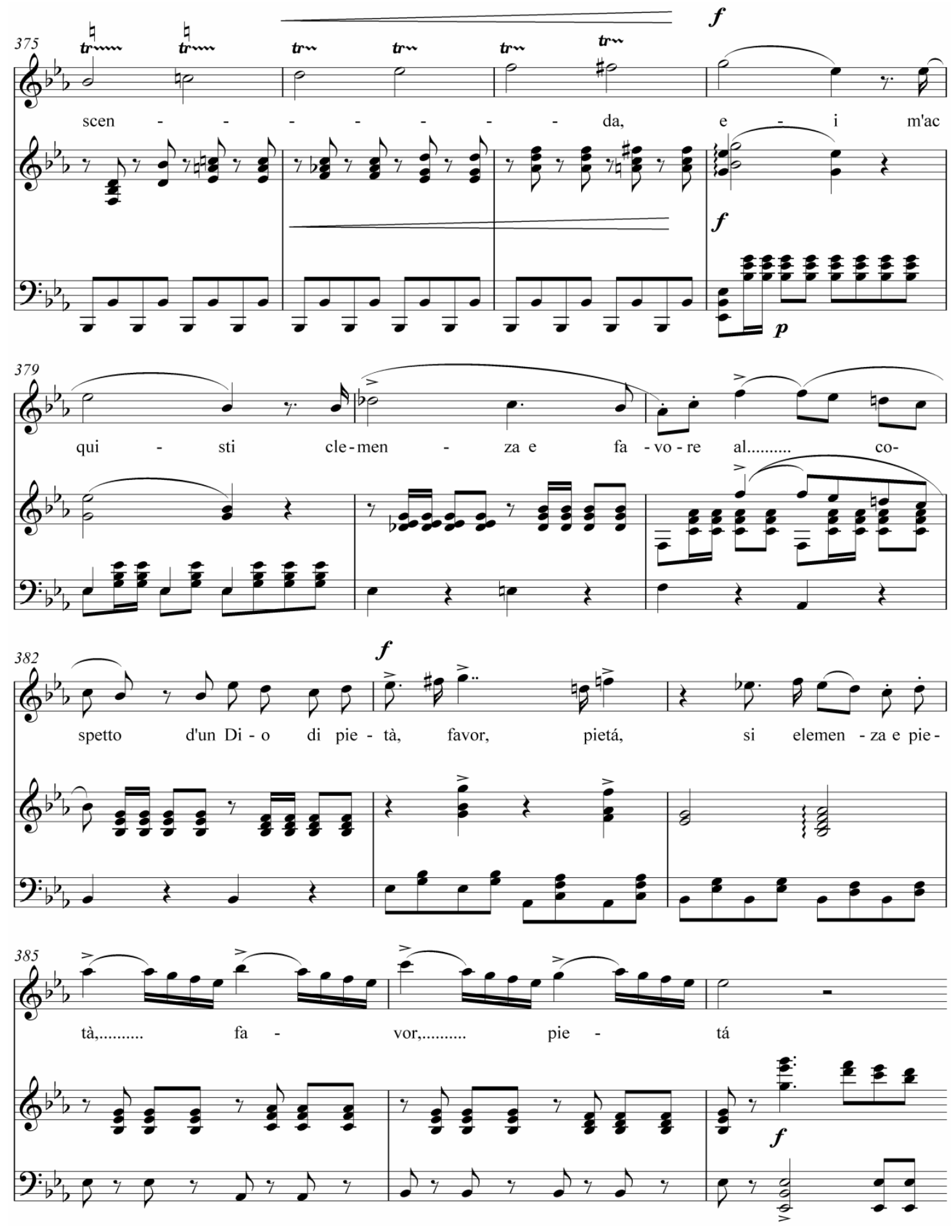


Her words are contrary to her music, as she sings: 'Coppia iniqua, l'estrema vendetta / non impreco in quest'ora tremenda... ei m'acquisti clemenza e favore / al cospetto d'un dio di pietà'. ['Unjust couple, the extreme revenge / I do not curse in this terrible hour... he may grant me clemency and favour / In the presence of a merciful God'] (example 2.5). Anna, impassioned, works herself up in her cabaletta, ending the opera not with death, but in a faint. Her ending is scarcely less tragic than Lucia's though, for the audience may assume she and her fellow treasonous prisoners face the block soon after.

The musical construction of the Gothic thus centres on Anna's demise, her extreme emotional states triggered foremost by her physical imprisonment. While Anna herself does convey the opera's locale through her own nationality, as one of English history's most infamous queens, her Gothic episode is a response to her setting and her plight. Although Anna sees no visions or ghosts - Anna Bolena contains no Gothic supernaturalism - she is still entombed within the male-dominated Gothic plot, where women appear only to exist in order to be silenced. Her literal prison is comparable to Lucia's figurative imprisonment in marriage to Arturo.

After considering how Anna herself - through her position as the irrational other - provides a Gothic atmosphere for Anna Bolena, and, in the previous chapter, how the landscape of Lucia di Lammermoor is saturated in the Gothic, we turn to Lucia herself and discover she is indeed a most intriguing Gothic heroine. Lucia is entrenched in the Gothic, and her musical characterisation shows a more pronounced emphasis on her internal and external worlds than can be seen in Anna Bolena. Lucia's spectral encounter in her cavatina gives the audience their first impression of the woman's irrationality, and helps to propel her towards insanity. Therefore a closer analysis of Lucia di Lammermoor contends simultaneously with the question of feminine 
importance in the Gothic and how in turn the opera operates as a portal from which to examine the liminal and subliminal realms in the opera's sound world. Lucia's response to the ghost she alone of the characters observes and her celebrated mad scene are fundamental to this approach, which takes its frame from the critical studies of Abbate and Gary Tomlinson. Furthermore, the irrationality and heightened emotive states displayed by Lucia throughout the opera portray her separation from other (usually male) characters.

However much the power is patriarchal in the narratives of Gothic literature, the integration and expansion of more 'operatic' episodes give women prominence and freedom in opera they lack in literature. In opera women are able to break free of the confinement present in Gothic literature through their voices, something that transcends the expectations of class and gender in the Gothic mode. Moreover, other (including male) characters in these operas, rather than only the soprano herself, are physically threatened. Men are stabbed, poisoned or beheaded by these women, always offstage, before her hopeless, passionate demise over doomed love. In her 'Opera; or, the Envoicing of Women', Carolyn Abbate questions whether in fact opera inverts the 'conventional opposition of male (speaking) and female (observed) objects' through the woman's vocal dominance, contrary to Catherine Clément's argument in Opera, or the Undoing of Women that their only freedom from male oppression comes with death. ${ }^{6}$ The centrality of women to the Gothic and in opera further emphasises Anna's role in creating Anna Bolena's Gothic mood. Her mad scene, which draws on contemporary representations of madness on the operatic stage, Imogene's insanity in Bellini's $\mathrm{Il}$ pirata for instance, has evolved by the time Donizetti writes Lucia five years later, in the wake of other violent and intensely dramatic works, including Lucrezia Borgia. In

\footnotetext{
${ }^{6}$ Carolyn Abbate, 'Opera; or, the Envoicing of Women' in Musicology and Difference, edited by Ruth A. Solie, Berkeley: University of California Press, 1993, pp. 228-9.
} 
addition to Abbate and Clément's musicological discourses on madness, Susan McClary explains in her discussion of Lucia di Lammermoor that Lucia, 'because she is mad...cannot, of course, be held responsible for deliberate resistance [to her situation; oppressed by her brother]. Thus she can be victim and heroine simultaneously - in short, a martyr'. ${ }^{7}$ Whereas other prima donnas do not necessarily present their disturbed state of mind from the outset as Lucia does, because of the tension between their voices as empowering and their circumstances as suffocating, most can still be considered as both victims and heroines. Certainly Lucia, as a murderess, is neither the only victim of the opera, nor is she the only character to die grief-stricken. Lucia's (and also Lucrezia's) roles in causing the violent deaths of men set them apart from Anna, who is the only prima donna in the Gothic operas of this study not to order or carry out another's death. ${ }^{8}$

Feminist interpretations of Lucia are significant, for the debate over why the prima donna dies has been ongoing since the 1970s, with Clément providing one of the earliest feminist critiques of opera. As one of many women to respond to the narrative of Lucia, Clément perceives that the deaths of these women in 'Gothic' operas are like the deaths of many other women who die in opera. She emphasizes that whether the opera is set in Classical antiquity, Africa, Paris, or the underworld, we expect the death, and we could even go so far as to say we want it, as witnessing the vocal acrobatics of a prima donna's demise is one of the highlights of opera for many in the audience. ${ }^{9}$ Clément explains that her primary focus is on the text of operas, regardless of the essential musical element:

\footnotetext{
${ }^{7}$ Susan McClary, Feminine Endings: Music, Gender, and Sexuality, Minneapolis: University of Minnesota Press, 1991, p. 98.

${ }^{8}$ Even in Donizetti's other Tudor operas, the soprano (Queen Elizabeth I) is responsible for ordering executions.

${ }^{9}$ Catherine Clément, Opera, or the Undoing of Women, translated by Betsy Wing, London: Virago Press, 1989 , pp. 5 and 10-11.
} 
To commit the sacrilege of listening to the words, reading the libretti, following the twisted, tangled plots...initially this is not going to be about the music...I am determined to pay attention to the language, the forgotten part of opera. The part that always keeps to the shadows, although the words are still sounds and make music.'

While Clément acknowledges the operatic duality of words and music and that each relies on the other so heavily, it is not a point that she always foregrounds in her discourse when she privileges text over music. On the one hand, words to her are the murder weapon, the carriers of operatic 'meaning'. On the other hand, music is superficial beauty, yet powerfully seductive enough to mask what the words are saying. For unlike some of the more recent interpretations of operatic madness which concentrate on musical representations of the soprano's irrationality, Clément fears a love of the music sweeps the audience away and is at times able to disguise the plot and the true meaning of the words - particularly if the opera is in a foreign language. Thereby the music is rendered 'a mysterious language of [the women's'] happiness.' 10 Interestingly, this professed emphasis on words usually lacks direct reference to the libretti itself during her dialogues, implying Clément conflates 'plot' and 'words', separating them from the 'privileged' position music holds. ${ }^{11}$ However much this can be seen as a liberating view on opera, it also is a somewhat limiting one, at times seeming to belittle those who have written about finding layers of meaning in the 'music itself', thereby enhancing the meaning given by the words. ${ }^{12}$ In spite of this text-centred perspective, Clément still manages to draw attention to what is so significant about music in opera, linking it to an expression of the unconscious and illuminating its ability to

\footnotetext{
${ }^{10}$ Ibid, p. 10.

11 Ibid, p. 20.

12 Ibid, p. 17.
} 
transcend stage boundaries in a way that text cannot, something essential when attempting to reveal the Gothic in music. ${ }^{13}$

In her interpretation of Donizetti's Lucia as a girl who 'leap[s] into space', Clément sees madness as the only way in which an operatic heroine can escape from subjugation and death. ${ }^{14}$ The most striking Gothic episodes in Lucia occur as the second and penultimate scenes in the opera, and it is with these scenes - but principally the mad scene - that Clément is concerned. Her novelistic retelling of the words (or perhaps more accurately, the plot), clearly show her analysis is concerned with the music only as a follower of the narrative, and able to be read separately from its text. This is evident when she describes Lucia's vocal line in the mad scene as 'intoxicated happiness' and declares 'the curtain falls on Lucia's jubilation, set free and rising still. ${ }^{, 15}$ Donizetti's heroine dies silently offstage, unlike most other women in grand opera in the later decades of the nineteenth century who die defiantly, or at least, as is the case for Anna too, with a final aria at their death. Alternatively, the mad scene allows her to end on a musical pinnacle, without seeing her death, the audience instead is able to remember her alive and singing, empowered by her voice. For Lucia's mad scene is the last time the audience hears her voice, making this final vocal display unsettling as the vastly different moods conveyed by the words and music are difficult to reconcile. ${ }^{16}$ The libretto is ambiguous, but when Lucia sings 'Spargi d'amaro pianto' ('Scatter bitter tears over my earthly remains, while above in heaven I will pray for you. Only when you arrive will heaven be beautiful to me!') she does not display the true joy Clément pronounces the libretto to inspire.

\footnotetext{
13 Ibid, p. 20.

${ }^{14}$ Ibid, p. 89.

${ }^{15}$ Ibid, pp. 88 and 90.

${ }^{16}$ Although Lucia's death is signified musically by a bell tolling and she is carried on stage in a funeral procession.
} 
The mad scene is perhaps a point where Clément herself loses the meaning of the words, and is seduced by the music and Lucia's vocal freedom, which has gone beyond the framework of the text and her role as the compliant sister and wife. That Lucia is mad from her happiness at being freed from her husband - the pawn of her brother rather than at the grief over her apparent desertion by Edgardo seems implied by the music. Yet, as William Ashbrook and Julian Budden suggest, her dejection is expressed in a way which makes Lucia's insanity and distance from reality all the more affective. ${ }^{17}$ The reality of what is 'visible' to the audience is further heightened by the way Clément peppers her monologue with references to Lucia's body, something contained by neither text nor music. This seems to have the effect of pulling her down, into the visible realm of the stage. Her voice utters beyond it, vying for release in a way that, as Mary Ann Smart has indicated, shows Lucia's vocal expression is her freedom. ${ }^{18}$ Her voice is Lucia's only escape from both the conventions of Italian lyric form and the men that suppress her within the plot. Nonetheless, she is never given total vocal freedom because where her coloratura occurs it is contained within the structural traditions of Italian opera, for example at the ends of phrases. Coloratura is also a point where she is free from Gothic literary conventions, where women usually get no voice, instead narrated by men.

Susan McClary picks up on a moment of apparent 'rationality' in her examination of Lucia from a more musical perspective than Clément: Lucia's striking instant of lucidity in the mad scene. ${ }^{19}$ McClary notes that Lucia 'seems to be submitting to the socio-musical frame she has resisted throughout the opera' in the conventional first

\footnotetext{
17 'The brilliant cabaletta "Spargi d'amaro pianto" shows a curious indifference to the mood of Cammarano's text...Lucia lacks the excuse of morbid euphoria for her roulades.' William Ashbrook and Julian Budden, 'Gaetano Donizetti', The New Grove Masters of Italian Opera, New York: Norton, 1983, p. 114, quoted in McClary, Feminine Endings, p. 92.

${ }^{18}$ Mary Ann Smart, 'The Silencing of Lucia', Cambridge Opera Journal, Vol. 4, No. 2 (July, 1992), pp. $119-20$.

${ }^{19}$ McClary, Feminine Endings, p. 93.
} 
section of her mad scene cabaletta, 'Spargi d'amaro pianto', but the divorce between Cammarano's libretto and her vocal line continues to be unsettling. ${ }^{20}$ Up to this point, all Lucia's lyrics relating to 'other-worldliness' have been accompanied by a musical signifier - heavy accents, modulation or a particular interval - yet here, despite singing of her own deathly transcendence between Earth and heaven, there is a troubling delayed musical reaction. It is not until her ' $\mathrm{B}$ ' section, when she sings of Edgardo's arrival in heaven, that her unhinged state becomes more obvious. That Lucia's lyric depiction of her own death conforms to established musical structure for this brief time perhaps indicates that she has realised her fate. Although Lucia is a male-authored work on multiple levels, music allows the power of self-representation that women customarily had been refused in other art forms, and the excess that marks her repeat of the ' $\mathrm{A}$ ' section is her last bid at empowerment and freedom from structural boundaries before her inevitable death.

\section{Emma et Lucie}

Lucia, as well as being the most performed 'Gothic opera', also bears the accolade of being the most discussed Gothic opera in literature. For scholars and novelists alike, her tragic story has great appeal. It begins with her spectral vision and ends in desperation and insanity. Lucia, betrayed by her lover and brother, fatally stabs her new husband with his own knife before expiring herself. ${ }^{21}$ In Flaubert's Madame Bovary, the title character, Emma Bovary, is figured, sardonically, as another Lucia, constricted by the expectation of her role as a woman in the nineteenth century and by her

\footnotetext{
${ }^{20}$ Ibid, pp. 92-3.

${ }^{21}$ For clarity, when I refer to the Lucy of the French version specifically, including as the woman Emma sees, I will use Lucie, but when it is within the more general context of the opera, or refers to both, I will use Lucia.
} 
relationships with the men around her. Emma attends a performance of the French adaptation of Lucia, Lucie de Lammermoor, with her husband and, coincidentally, her lover, and follows the story from her recollections of Scott's novel. ${ }^{22}$ The opera echoes through the Flaubert's novel, reinforcing at various points both Emma's overactive dramatic sensibility and her ill-omened end. ${ }^{23}$ One of the most notable features of the scene in which Emma attends Lucie is the difference between her response, and that of her husband, Charles. Emma responds to the opera by sympathising with Lucie and her tragic situation, but sees Lucie as possessing insight Emma does not, in her 'resistance' to her marriage to Arturo. ${ }^{24}$ Like the Gothic novel, which Donizetti's characterisation of Lucia reflects, the opera appeals to its female audience who are seeking ways to find their own empowerment, in Emma's case, through a series of affairs. Emma's response to Lucie is intriguing because it conveys Emma's own shift between fascination and indifference:

Emma was back in the books she had read as a girl - deep in Walter Scott. She imagined she could hear the sound of Scottish pipes echoing through the mist across the heather. Her recollection of the novel made it easy for her to grasp the libretto; and she followed the plot line by line, elusive, halfforgotten memories drifting into her thoughts only to be dispelled by the onrush of the music. She let herself be lulled by the melodies, feeling herself vibrate to the very fibre of her being, as though the bows of the violins were playing her nerve-strings. She couldn't take in enough of the costumes, the sets, the characters, the painted trees that shook at the slightest footstep, the velvet bonnets, the cloaks, the swords - all those fanciful things that fluttered on waves of music as though in another world. Then a young woman came forward, tossing a purse to a squire in green. She was left alone on stage, and there came the sound of a flute, like the ripple of a

\footnotetext{
${ }^{22}$ Flaubert's use of Lucia in his novel has been noted numerous times, including in Smart, 'The Silencing of Lucia', pp. 120 and 133; McClary, Feminine Endings, p. 99; Herbert Weinstock, Donizetti and the World of Opera in Italy, Paris and Vienna in the First Half of the Nineteenth Century. London: Methuen, 1963, p. 111; Kimbell, Italian Opera, Cambridge: Cambridge University Press, 1991, p. 489; Lindenberger, Opera, The Extravagant Art, Ithaca: Cornell University Press, 1984, p. 173. In none of these, however, is the novel considered in any great detail, with most allowing it only as a passing reference.

${ }^{23}$ An example of this would be her meeting with Léon in Rouen near where 'the fountain gurgled', Gustave Flaubert, Madame Bovary, translated by Francis Steegmuller, London: Random House, 1993, p. 226.

${ }^{24}$ Flaubert, Madame Bovary, p. 212.
} 
spring or the warble of a bird. Lucie, looking solemn, began her cavatina in $\mathrm{G}$ major: she uttered love laments, begged for wings. At that moment Emma, too, longed that she might leave life behind and take wing in an embrace...Emma strained forward to watch him, her fingernails scratching the plush of the box. Her heart drank its fill of the melodious laments that hung suspended in the air against the sound of the double-basses like the cries of shipwrecked sailors against the tumult of a storm. Hers was the same ecstasy, the same anguish that had brought her to the brink of death. The soprano's voice seemed but the echo of her own soul, and this illusion that held her under its spell a part of her own life. But no one on Earth had ever loved her with so great a love. That last moonlight night, when they had told each other, 'Till tomorrow! Till tomorrow!' he had not wept as Edgar was weeping now... and when their voices rose in the final farewell, Emma herself uttered a sharp cry that was drowned in the blast of the final chords...But from that moment [the third Act] she listened no more...the mad scene was little to Emma's taste, and Lucie seemed to her to be overacting. $^{25}$

Unlike her husband who claims that the music of opera obscures the plot, Madame

Bovary reacts to the music as the fundamental emotive ingredient. However, as Emma loses interest in the opera, bored by the mad scene, ('she shouts'), Charles has been swept away by the music. Unlike his wife's earlier reaction to the cavatina, Charles, despite his enjoyment, is able to draw himself away from the scene. He is not bound up in the characters as Emma is initially.

There are a number of factors that determine that Emma and Charles Bovary are attending a production of Lucie de Lammermoor, which was performed in the provinces not long after its premiere at the Théâtre de la Renaissance in $1839 .^{26}$ These include the appearance of the character of Gilbert, a corrupt conflation of Scott's Caleb

Balderstone, the Ravenswood family retainer, and Ashton's huntsmen who only appears in Lucie (Gilbert is loyal to neither Edgard nor Ashton). The absence of Alisa, which can be noted when Lucie is 'left alone on stage' indicates the Bovarys attend Lucie. Another clue is that the instrument Emma listens to at the beginning of the aria is a flute, rather than the extended harp introduction of the original Italian opera. Alisa's

\footnotetext{
${ }^{25}$ Ibid, pp. 210-4.

${ }^{26}$ As noted from information supplied in the adapted and translated libretto, Weinstock, Donizetti, p. 144.
} 
absence is especially noticeable as Lucie is now isolated as the only female character in the opera. Her position as the pawn in the patriarchal game is magnified and her appeals to her dead mother seem all the more wretched. The difference in instrumentation between the cavatinas of Lucie and Lucia confirms the interpolation of Donizetti's cavatina from Rosmonda d'Inghilterra ('Perché no ho del vento'...'Torna, torna, o caro oggetto') in place of 'Regnava nel silenzio'... 'Quando rapito in estasi', as is standard practice in the French version. ${ }^{27}$ The music from Rosmonda has undergone only minor changes for its inclusion in Lucie as 'Que n'avons nous des ailes'... 'Toi par qui mon coeur rayonne', mainly to fit with the text, which is neither a direct translation from Lucia or Rosmonda. This substitution can furthermore be assumed here from Emma's reference to Lucie 'beginning' her cavatina 'in G major'. ${ }^{28}$ In the Italian version, provided the singer is adhering to Donizetti's original key, it is the cabaletta in G major, rather than the cantabile, which is in D minor.

Flaubert's assertion that Emma is able to follow 'the [opera's] plot sentence by sentence' based on her recollections of Scott's novel is not necessarily an oversight on his part, but rather illustrates the time that has lapsed between Emma's reading of Scott and her viewing of the opera. The presentation of Scott's novel within Flaubert's novel constructs an intertextual framing of the feminine, within which Lucie's irrationality is projected onto Emma, who has more insight into the soprano's character than her husband. Emma does not appear to be captivated with the spectacle so much as with an emotional shared understanding with the heroine: while 'she couldn't take in enough of the costumes, the sets, the characters, the painted trees' it is the music that overwhelms

\footnotetext{
${ }^{27}$ See William Ashbrook, Donizetti and His Operas, Cambridge: Cambridge University Press, 1982, pp. 84 and 210; Smart, The Silencing of Lucia, p. 134.

${ }^{28}$ Flaubert's sentence here is 'Lucie entama d'un air brave sa cavatine en sol majeur' (italics mine), implying the cantabile, rather than cabaletta is in $\mathrm{G}$ major. These were not the keys given in the autograph manuscript, which were a semitone higher. Donizetti's keys are preserved in the French version most of the time, making the highest note of the soprano (in the mad scene) a D, instead of an E flat.
} 
her, 'her heart dr[inking] its fill of the melodious laments that hung suspended in the air'. Emma at this point, far from her horrifyingly realistic end, aspires to be like Lucie.

Flaubert's novel may have been read by the same people who enjoyed Scott. Madame Bovary was first serialised in La Revue de Paris in 1856 (and published as a book in 1857). ${ }^{29}$ It is interesting to consider Flaubert's novel from an operatic perspective, as there are a number of things that stand out as being similar, especially in characterisation. There is a difference between the Emma the public and her husband see: the pale, placid, yet stylish lady, prone to letting her Romantic sensibilities get the better of her, and the private Emma, who secretly meets her lovers in a hotel room or on the garden seat. This bear comparison with Lucia, who seems malleable to the desires of the men around her and has a tendency to be susceptible to influences from otherworldly realms, yet murders her husband in the privacy of the bedroom. Emma is (in her own mind) Lucia. Although still sane, she is possessed by unreason, both in her spending habits and in believing that her way to freedom lies in death; a suicide-death, riddled with guilt, which she thinks will fulfil some sort of Romantic notion and atone for her perfidy. For the reader, it is here that Emma and Lucia's paths diverge. Emma is bound by materialism. She believes she will find her happiness through possessing things and lovers to pander and indulge her; she responds to the loss of both by choosing to commit suicide, feeling she has nothing left to make her happy. Even her death is still materialised, as in her final moments Flaubert focuses on her surroundings, her bed, her need to see herself in a mirror and, most of all, her inability to transcend her physical pain. Lucia, also driven in part by lost love, escapes the material to the insubstantial realm of insanity. However, unlike Emma, her love is reciprocated, not one that relies on possession, and Lucia does not knowingly choose her death. Her

\footnotetext{
${ }^{29}$ Despite the journal publishing Madame Bovary in a censored version, they were tried for salacious content, but acquitted.
} 
flight to delusion depicts other-worldly transcendence that Emma has no interest in watching as Lucie performs her mad scene. As much as Emma feels she understands Lucie in her cavatina, Lucie's tragic end is beyond Emma. She wants to escape into Lucie's world of love, not her world of madness. Thus Emma's Romanticised reenactment bears little resemblance to the death of the operatic heroine she supposedly models.

Yet Emma's response to Lucie returns to a fundamental necessity of opera, and especially Gothic opera, where rationality must often be suspended for the extravagant spectacle to have its dramatic affect. Lucia lives in a mystical and unnatural world, where victim-heroines die as martyrs, in the space of a few hours in 'real' opera time. ${ }^{30}$ Emma believes she too can die this way, but as it is for Scott's Lucy in The Bride of Lammermoor, her death is anything but the magnificent act she envisages. Instead, it is vulgar, appealing to the grotesque and Gothic aspect of Romanticism and gratifying the lust for sensation, repulsion and excitement. Like Lucia, Emma's life ends after a mad scene of sorts, she too has killed her husband, emotionally, through lying, betrayal and grief at her death rather than literally; and in her heightened emotional state after discovering her material life is to be repossessed, several other characters question her sanity. Despite the Romantic deaths of many a literary heroine, they all occur in worlds set up as 'other' in some way. Flaubert's provincial setting is no exception, acting as the 'other' for the majority of his Parisian readers. But Emma does not live in a fantastically 'other' operatic world as Lucia does. Thus Emma's excruciatingly slow death provides a shock of 'realism' in Madame Bovary, portraying the provincial as unromantic and mundane and highlighting the irrationality of the opera itself in the novel. Madame Bovary is told from the narrator's perspective - as Emma is dying we 'watch'

\footnotetext{
${ }^{30}$ Lucia's time of death can be placed at some time just after dawn, as Edgardo hears the bell tolling to mark her passing just before he dies himself following his duel with Enrico.
} 
her and 'hear' her groans figuratively, but she is never given the opportunity (albeit as an inevitable result of third-person narrative) for more self-expression than this: there is no chance of the jubilation, which even if it does not seem entirely comprehensible, marks Lucia's music. Emma is contained in a way that Lucie, as irrationally operatic and moving beyond physical realms, is not. In opera the female singer has a literal, audible voice; she is able to shape the music and is thus empowered by it. Emma highlights her female irrationality by empathising with Lucie in the first place. However, the reason for her dismissal of the mad scene is due to her own desires, for Léon, her lover, enters the Bovary's box in the time between the cavatina and the mad scene. It could be argued that Emma, who Flaubert himself identified with when he famously announced 'Emma, c'est moi', gives a typical French response to the opera.

From Rebecca Harris-Warrick's accounts of contemporary reviews of Lucie, the scenes favoured by the French were those which featured Edgard - the Act 1 duet, the Act 2 finale and his suicide scene. The French public, like Emma, were not persuaded by Lucia's mad scene, which seemed to them banal. ${ }^{31}$ This attraction to the tenor was heightened when Dupez, despite qualms about his ability to pull off the role, returned to the stage as Edgard in $1846 .{ }^{32}$ The dethroning of Lucia/Lucie as the lead character in some ways conveys that the French audience were not responding to the Gothic in opera. For once the original cavatina has been substituted in the Paris version; there remains nothing to satisfy the French appetite for the fantastic. In a city where Lucie's dress would have invoked conventional depictions of madness, Lucie's insanity lacked the dramatic power of Edgard's suicide. ${ }^{33}$ For Italian audiences, who had less (although

\footnotetext{
${ }^{31}$ Rebecca Harris-Warrick, 'Lucia Goes to Paris', in Music, Theater, and Cultural Transfer: Paris 18301914, edited by Annegret Fauser and Mark Everist, Chicago: University of Chicago Press, 2009, p. 203.

${ }^{32}$ Rubini was the tenor for Lucia and Lucie in Paris (along with Persiani as Lucia/Lucie).

${ }^{33}$ Shakepeare's Ophelia was presented on stage in a white gown from at least the 1820s, as were madwomen in art, in Tony Robert-Fleury's painting of Pinel freeing the insane at the Salpêtrière asylum in Paris, for instance.
} 
certainly increasing) exposure to such depictions of female hysteria, it was perhaps more moving, and certainly the singer-focused reviews of Lucia's premiere would suggest the scene impressed its audience then.

However, it was still death, even if it was not the soprano's, which captivated the Parisian audiences. Emma, having left during the mad scene, misses Edgard's death. Yet in the duet, when Emma does hear Edgard sing, she still considers him in relation to the soprano and her own life, within which her own men are no match for the love-struck tenor. Carried away with the music, Emma, in spite of actively comparing how Lucie's plight mirrors her own, seems to lose the distinction between her imagination and reality. She is unable (or even refuses) to see past this one scene and truly map the distinction between operatic fantasy and actuality. Thus while Emma's response to Lucie does not emphasise a particular affinity with the Gothic, it does shine a spotlight over the centrality of women in opera more generally, their Abbatean vocal empowerment, and the extent to which Flaubert uses the operatic scene to distinguish the irrationality of his fictional heroine in his quasi-realist novel.

\section{Other Voices}

An interpretation of the Gothic in Lucia di Lammermoor delves into one of the facets inherent to opera and the Gothic highlighted by Flaubert's use of Lucie to underpin the materiality of Emma's life. Lucia personifies the disembodied through her associations with the supernatural, while also transcending her physical environment into abstract, unearthly spheres through her altered states of mind - hallucination and hysteria. Such an excursion into the metaphysics of her internal mind and its external objectivity can 
be instigated from the influential critical studies of Carolyn Abbate and Gary Tomlinson. These studies provide a framework to investigate transcendence beyond physical realms and the issues of voice and 'envoicing'.

The idea that multiple layers of sound portray the psyche of a character and the interrelation of their internal and external spaces implies a particularly German aesthetic, as both Abbate and Tomlinson (in response to Abbate) rely on terms and ideas from Kantian philosophy. Abbate's primary material is German music, particularly Wagner and Mahler, and it is with this repertoire that she lays out her noumenal and phenomenal distinctions. Nevertheless, she, and (to a greater extent) Tomlinson, also relate their concepts to operas from outside the German tradition. Tomlinson's examples of the approach of noumenal limits are taken from Italian opera, specifically, scenes of madness in Verdi's Macbeth. The music of Macbeth shows how a character's mental instability pushes forth thoughts suppressed in an internal world, which becomes objectified in scenes of madness or altered consciousness. Similar ideas can be applied to Gothic episodes in Lucia di Lammermoor, Lucia's hallucination and mad scene expressly.

The phenomenal is the realm where music is experienced, perceptible as part of the operatic diegesis. ${ }^{34}$ Consequently, the noumenal constitutes what is beyond the operatic stage. 'Beyond the stage' refers not simply to the offstage space, which as Abbate points out, can be invoked or formulated by the characters' narratives or actions - they can easily reach offstage by walking. Rather, 'beyond the stage' embraces essentially all music with which the characters do not self-consciously identify. ${ }^{35}$ In practice, the noumenal amounts to all the orchestral and vocal music that the characters

\footnotetext{
${ }^{34}$ Carolyn Abbate, Unsung Voices: Opera and Musical Narrative in the Nineteenth Century, Princeton: Princeton University Press, 1991, p. 5.

${ }^{35}$ Abbate, Unsung Voices, p. 239.
} 
are 'deaf' to: they fail to hear it as music and respond to it as such. ${ }^{36}$ As a result, crossing the noumenal threshold has the potential to expose the uncanny elements of the Gothic in opera.

Tomlinson responds to Abbate's use of the 'phenomenal' and 'noumenal' as 'indulgent'. Instead of the noumenal representing almost the entire atmosphere of the operatic world, Tomlinson limits it to particular moments when a character becomes self-aware of their musical experience. In other words, a character who is singing becomes aware of some musical sound, whether it is in the orchestra or their own voice, but other characters also on stage may not 'hear' what that character 'hears'. It is at this point, where they approach the objectivity of the phenomenon, that there is some alteration of character. This is usually seen through their interaction with their musical surrounding; the character becomes part of the operatic discourse, able to envoice the internal, usually concealed realms. Such a musical self-consciousness provides the opening for the Abbaten numinous intruder - a ghost or vision who is not fully part of the obvious phenomenal/physical world. ${ }^{37}$

Both Abbate and Tomlinson emphasise the point where there is some 'alteration' of character, usually seen through their control or creation of the music around them and their ability to 'hear' and engage with their surroundings. Moreover the character is able to become part of the operatic discourse themselves and to internalise music from their audible realm, sometimes with the effect that the audience realises that they, in fact, can be 'deaf' to the music the characters hear. For Abbate this is entwined with moments which reveal the narrative voice, though Tomlinson distinguishes this as unearthing 'the noumenal limits of knowledge' and allowing

\footnotetext{
${ }^{36}$ Abbate, Unsung Voices, p. 119.

${ }^{37}$ Gary Tomlinson, Metaphysical Song: An Essay on Opera, Princeton: Princeton University Press, 1999, p. 89.
} 
characters to reach the edge of consciousness and envoice their own, usually concealed subconscious. ${ }^{38}$ Reaching the verge of this noumenal realm provides the opening for the Abbatean 'nouminous intruder', which in a study of the Gothic is most evocative. As Tomlinson explains noumenalism is revealed most clearly in mad scenes and other passages that construct similarly altered mental faculties including 'sleepwalking, dreaming and entranced vision'. ${ }^{39}$ Tomlinson substantiates this argument by exploring motivic motion in Macbeth, showing that these altered states of mind are internalised. Rather than an outward reach of the psyche, the music shows how the disintegration of consciousness in states of madness unveils the subliminal world, which itself is shaped by an internalised understanding of this consciousness. ${ }^{40}$ In Macbeth, the title character's lamenting flat sixth motive reappears soon after he sings it, supressed in his internal world.

\section{Although Elizabeth Hudson and Melina Esse indicate that Tomlinson's}

discourse is persuasive, they have found fault in Tomlinson's assessment of the way in which noumenal realms can occur in Italian opera without denoting a Germanic, specifically Wagnerian, analytical mode through an exploration of musical transcendence and the subconscious. ${ }^{41}$ For them, Tomlinson's preoccupation with the metaphysical overlooks the physical or visible presence of the singers and the significant position the female body holds on stage. Tomlinson misses what Hudson calls the 'immediacy of enactment' on stage, which links to the partly improvisory nature of coloratura that was emphasised in the early nineteenth century over the

\footnotetext{
${ }^{38}$ Ibid, p. 90.

${ }^{39}$ Ibid, p. 93.

${ }^{40}$ Ibid.

${ }^{41}$ Melina Esse, 'Donizetti's Gothic Resurrections', Nineteenth-Century Music, Vol. 33, No. 2, (Fall 2009), p. 93. Hudson explains that 'Tomlinson's reading rests on an abstraction - the functioning of a motive. On one hand, this ties his reading to a long tradition of Verdian analysis, which focuses on motivic appearances and tonal schemes. But it places that motivic analysis at the service of a distinctly Wagnerian conception of the sound world of opera: Hudson, “"...qualche cosa d'incredibile...": Hearing the invisible in Macbeth', Cambridge Opera Journal, Vol. 14, No. 1 (March 2002), p. 14.
} 
dramatic style Wagner (and later Verdi) subsequently required. ${ }^{42}$ Esse sustains Tomlinson's emphasis on analysing musical motives in her study of two of Donizetti's Gothic operas, while also remaining in the context of Italian operatic structure. All the same, rather than addressing those musical elements that expose only hidden spaces, she examines the musical illustrations of moaning, sobbing and sighing that signify (involuntarily or not) the audible bodily response to terror-inducing Gothic situations:

Donizetti's musical markers of the uncanny rely on the very materiality they seem to renounce. All are imitations of actual bodily sounds or gestures, but divorced from their visible sources: trembling limbs that belong to no one; sounds of weeping bourne on the wind. These musical evocations of the supernatural get their power to disturb from their own "spectrality," their ability to float free of the material bodies they necessarily evoke. ${ }^{43}$

Such an approach to the Gothic is also conducive to revealing the Gothic in Lucia. We have already seen the significance of a woman's position, both physically and figuratively (whether trapped in a tomb or by an arranged marriage agreement); therefore, to involve their physical presence on stage as a signifier of the Gothic seems appropriate. As the sounds of supernaturalism are unbound from physicality, there is not the revelation of the invisible to the visible (or more correctly in musical terms, the silenced to the audible) that Tomlinson suggests. If the source of the sound is hidden from the sight of the audience and characters, yet still audible in the music, the realm the supernatural Gothic inhabits is close to Tomlinson's noumenalism and the psychological uncanny: the sound's origins are concealed within the imaginations of the character. ${ }^{44}$ Thus while sighs and sobbing are linked to the body, the source of the sound still, as a symbol of terror, haunts the imagination. The key distinction here is between the supernatural and the metaphysical that conveys a somewhat blurry territory

\footnotetext{
${ }^{42}$ Hudson, "”...qualche cosa d'incredibile...": Hearing the invisible in Macbeth', p. 14.

${ }^{43}$ Esse, 'Donizetti's Gothic Resurrections', p. 93.

${ }^{44}$ This is what occurs in Macbeth, as Lady Macbeth hears the lament motive as an owl, but the owl's physical form only exists in her imagination, if it exists at all.
} 
of invisible materialism. Yet the two perimeters of the supernatural and psychological meet and overlap in scenes such as Lucia's cavatina. In this instance, the supernatural and the psychological are interwoven as Lucia is caught up in a cycle of the ghost and her own mental fragility: driven to a heightened state of fervency, her vision of the phantom means her hold on lucid reality stumbles, though she regains some balance, the encounter has weakened her and made her more susceptible to mentally fall again. If the ghost of the Ravenswood victim is depicted at all, it is through Lucia. It has no physicality of its own and remains invisible but for her imagination. In Donizetti's opera, as in the novel, this phantom has no voice, she is mute, and relies on Lucy's (and Lucia's) telling of the story to be heard. Therefore her voice and tale are Lucia's, and each is a victim of passion and male manipulation. As the phantom makes its mark on Lucia's state of mind through her hallucination, the difference, yet co-dependency of the supernatural and psychological elements of the Gothic emerge.

Esse makes a further contrast of the 'duality' between 'melodramatic spectacle' and the 'terror of the unseen'. ${ }^{45}$ Just as it is within the literary Gothic genre, horror or terror is invoked by instances of bloody materiality and the partially-perceived forms of the supernatural. In Lucia, Lucia herself is the spectacle, and the phantom the unseen, conveying that one side is expressed though the other. Lucia has no visible emblem of the Gothic akin to the urn containing Raoul's heart in Gabriella di Vergy. Thus any portrayal of the Gothic in Lucia is more reliant on the envoicing of the disembodied and an ability to transcend physicality while simultaneously enforcing it. Whether the audience can see this source or not changes how the uncanny is revealed, either as a symbol of the uncanny breaking the surface of the phenomenal or as horror or terror is invoked in opera by supernatural beings or sounds with no physical form or source. If

${ }^{45}$ Esse, 'Donizetti’s Gothic Resurrections', p. 84. 
the source of the sound is not visible for the audience or the characters to see onstage, then it suggests the sounds belong more to Abbate's phenomenal offstage, rather than reaching for a noumenal limit.

With these views in mind, the Gothic relates to musical expression and dramatics in greater depth than many who have focused only on how opera diverges from literary models have demonstrated. ${ }^{46}$ A move into the music 'proper' tussles once more with the entwining of the Gothic and the operatic, the physical and the otherworldly or supernatural, and the tension and interplay between voice and orchestra.

\section{'L'ombra mostrarsi'}

Lucia's fragility of mind is evident from her earliest appearance, as she enters the stage with Alisa for her cavatina in Act 1, scene 2 under direction to act 'nella massima agitazione' ['In great distress']. It is an unusual sortita from the outset as the introduction is virtually the same length as the preludio for the entire opera. As the harp begins its lyrical, extended solo passage, Lucia is further instructed to 'si volge d'interno, come in cerca di qualcuno; ma osservando la Fontana, ritorce altrove lo sguardo' ['cast around, as if she is looking for someone, but noticing the fountain, shift her glance elsewhere']. The harp line that underpins these actions is significant because it serves to envoice Lucia in a number of different ways. While Donizetti's use of the harp at Lucia's first entrance invites a strong comparison between Scott's Lucy and Donizetti's heroine, the instrument also evokes how Lucia is situated within her musical and physical context. Moreover, its power of envoicing is accentuated because its line breaks off just as Lucia's own voice enters in the scena. There is a distance between the

\footnotetext{
${ }^{46}$ Such as Stephen Willier's dissertation The Impact of the Gothic on Early Nineteenth-Century Opera, (PhD, University of Illinois, 1987) which links themes between the literary Gothic with themes in opera.
} 
musics of the opera's sound world - between the vocal and instrumental dimensionswhich is played out in contrast between what is visible or invisible in relation to Lucia's body. For it is through her physical presence on stage that she appears simultaneously to be detached from her music in the opening scena (as she is not the source of the sound), and embodied by it. Her physical location intrudes into her thoughts, conjuring up her past experience at the fountain where she saw the ghost of a woman murdered by a Ravenswood long ago. Subsequently, her mind is preoccupied with an uncomfortable awareness of her surrounding from the moment she sets foot on stage.

Example 2.6: Harp introduction to Lucia's cavatina, Act 1, Donizetti's Lucia di Lammermoor, bb. 1-8.
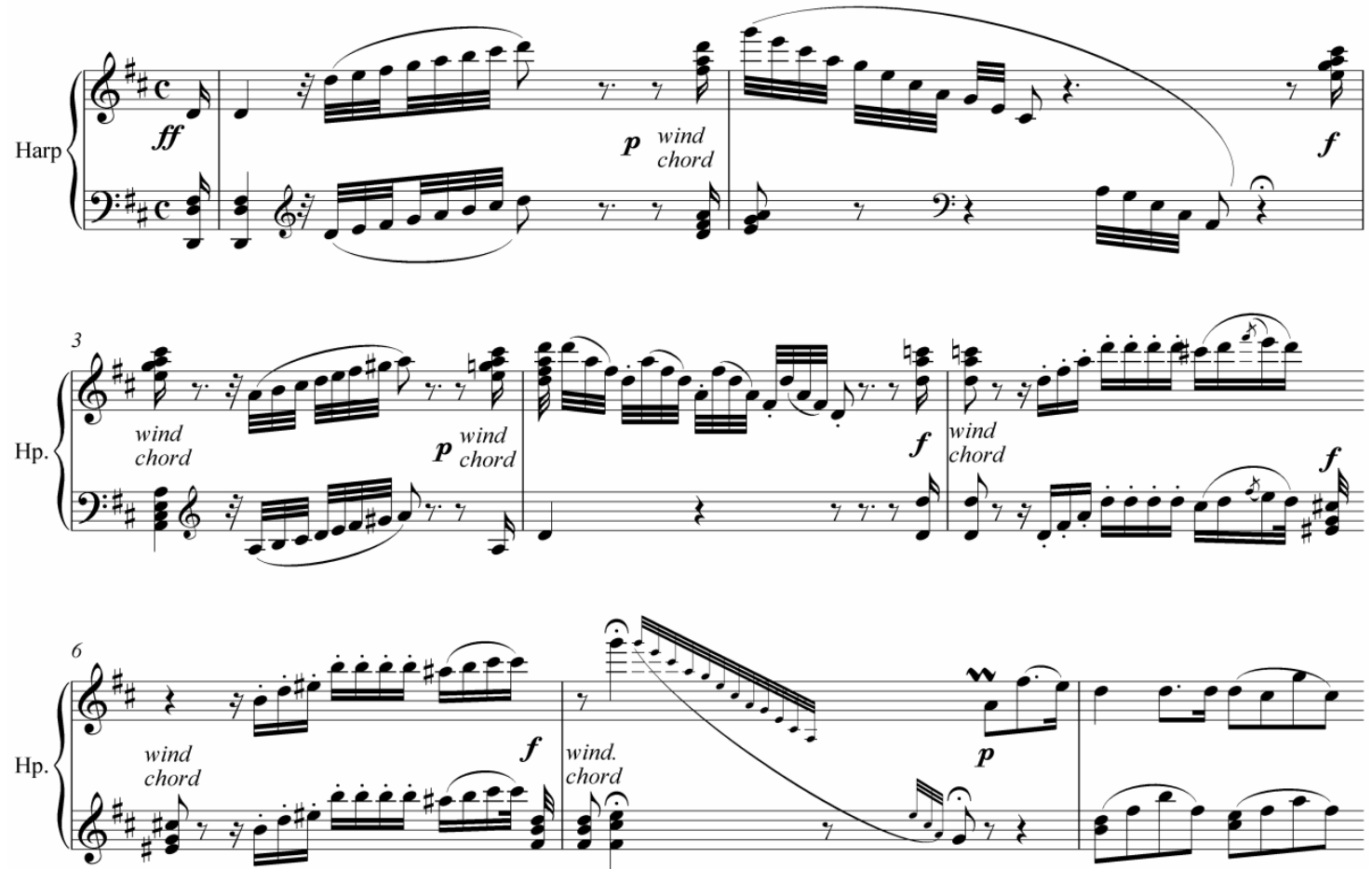

Lucia wavers between reality represented by Alisa (who enters the scene with her), and her internal recollection of the vision, which conveys her mental fragility and triggers a rising horror and sense of foreboding for Alisa and the audience. The tension between 
Lucia's reality and her imagination is aligned with the harp melody, which both traps and liberates Lucia while it envoices her. The harp line traps Lucia as it frames her entrance and she has no control over its sound. On the other hand, the virtuosity of the harp line is comparable to Lucia's vocal coloratura, particularly as the harpist is given further opportunity for embellishment in the cadenza (example 2.6). What this tension between confinement and freedom shows, however, it that the harp line is subject to the same conditions as Lucia's voice. The harp becomes Lucia's own noumenal voice, expressing her subconscious distress and obsession with her vision before she vocalises them herself in her narrative. It thereby marks the other-worldly internal realm though its vocality and its ability to transcend physical boundaries because it is not tied to a visible source: it embodies Lucia's internal world. It is used in a similar way, although less explicitly, as the flute in the cantabile and later the mad scene, where the relationship between the two voices culminates in the cadenza of the mad scene. ${ }^{47}$ Lucia responds to the flute, interacting with its voice in her confused utterances. Significantly, the extended envoicing of the flute greatly contributes to symbolising her distressed state in the mad scene, which illustrates Lucia's dramatic disembodiment by orchestral voices.

As well as demonstrating Lucia's centrality to uncanny Gothic representation, the harp introduction is reminiscent of the first description of Lucy in The Bride of Lammermoor, where she is portrayed in the midst of domestic music-making. Thus the harp too seems eerily stranded between phenomenal and noumenal. It evokes domestic music making and phenomenal song, yet it is not accounted for on the stage, and Lucy's environment contrasts with the rustic outdoor setting Lucia is part of:

${ }^{47}$ Smart, 'The Silencing of Lucia', p. 130. 
In passing through a large Gothic anti-room, Sir William Ashton heard the sound of his daughter's lute...He stopped, therefore, and listened, while the silver tones of Lucy Ashton's voice mingled with the accompaniment in an ancient and solemn air. ${ }^{48}$

The difference in the instrument between Scott and Donizetti is relatively inconsequential here: nineteenth-century portraiture shows it was popular for upperclass women to pose with a variety of instruments - particularly stringed instruments and keyboards. Rather, it is the act of Lucia's performance and the image of aristocratic and sentimental femininity (and its later subversion) that the harp symbolises. ${ }^{49}$ The harp became increasingly associated as a woman's instrument in the late eighteenth and nineteenth century, and images of women performing on harps in scenes of private musical performance are readily observed in both literature and art (figure 2.1). ${ }^{50}$

By the late eighteenth century harps with seven pedals, in which each individual string could be raised by a semitone, allowed for more complex harmonic changes and virtuosity. In addition to typifying Lucia through her class, Donizetti's decision to employ the harp in particular seems fitting with a heroine characterised as delicate and susceptible to Romantic imaginings:

\footnotetext{
${ }^{48}$ Walter Scott, The Bride of Lammermoor, edited by J. H. Alexander, London: Penguin, 2000, pp. 24-5. Lucy's father, Sir William Ashton, is a character done away with in every operatic setting of the text. ${ }^{49}$ Francis Collinson, The Traditional and National Music of Scotland, London: Routledge and Keegan Paul, 1966, p. 228.

${ }^{50}$ Hans Joachim Zingel, Harp Music in the Nineteenth Century, translated by Mark Palkovic, Bloomington: Indiana University Press, 1992, p.14. Although the harp was played privately, there does not appear to have been a rise in the number of professional women harpists (indeed, in my research I have found none).
} 


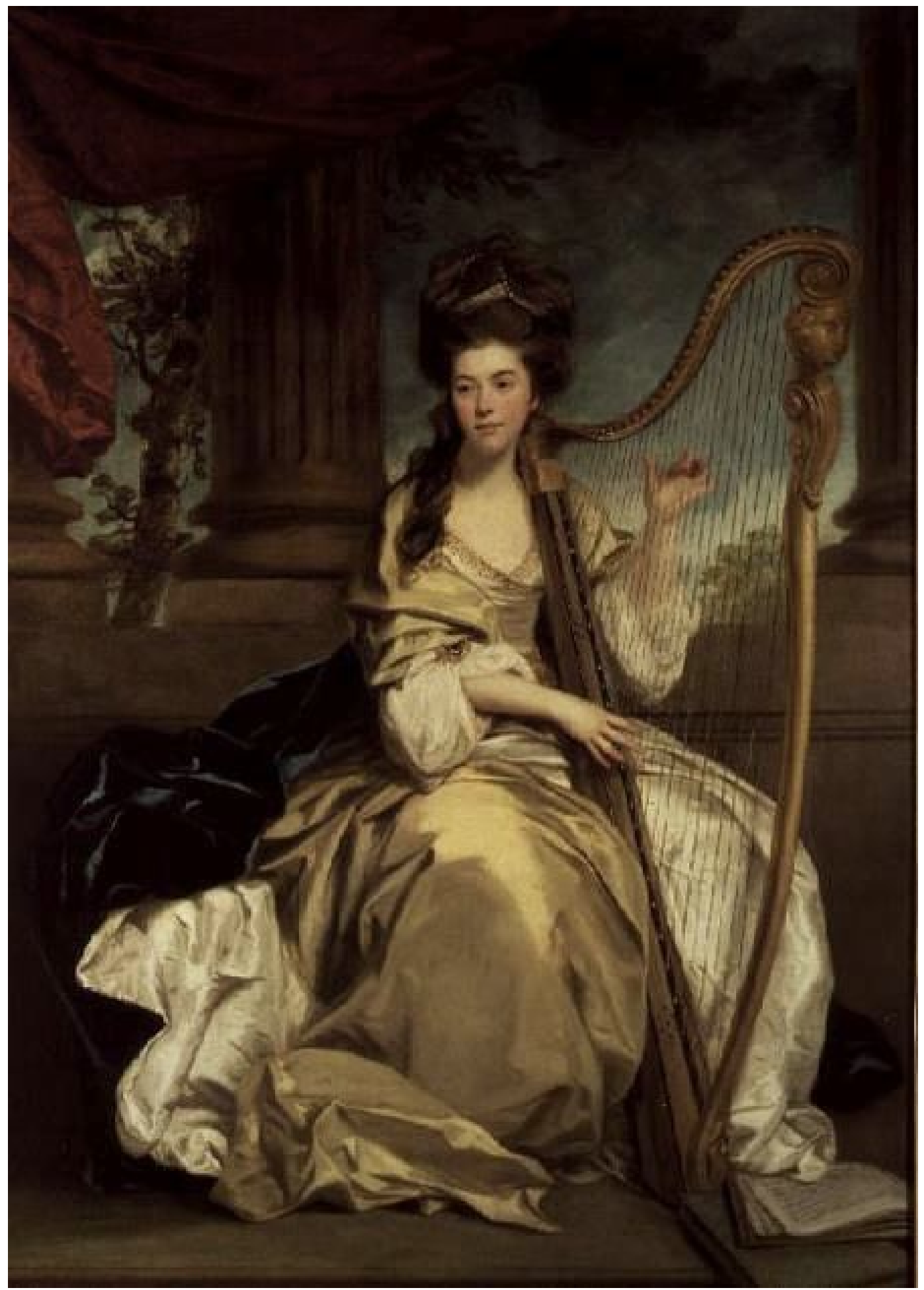

Figure 2.1: Joshua Reynold's portrait of the Scottish Countess of Eglinton (1777). Photograph courtesy of Agnew's, London/The Bridgeman Art Library. 
Lucy, when 'left to the impulse of her own taste and feeling...was particularly accessible to those of a romantic cast', taking 'secret delight in...tales of ardent devotion and unalterable affection... [and] supernatural horrors' ${ }^{51}$

By suspending Lucia's own vocal entrance over the harp solo, the instrument performs the first audible evidence of Lucia. The audience sees her visibly distressed, yet she is encased by an 'ideal' feminine musical sound - by a 'voice' that is not her own and which attempts to depict who she should be. It is perhaps this separation between Lucia's physicality and the 'invisible' music that Jerome Mitchell responds to in the conclusion of his discussion of Lucia. He remarks that Donizetti 'pretty much does away with Scott's carefully handled Gothic atmosphere, of which there is only a trace in Lucia's cavatina at the fountain'. ${ }^{52}$ Mitchell further describes the scene as 'picturesque' and 'quiet', and though it is easy to imagine how the Gothic here could become embroiled in only the visual aspects of the staging, or the libretto, the music is integral in enhancing the intrusion of the Gothic, configured by the supernatural and the other-worldly into the scene - and, crucially, Lucia's own internal world. ${ }^{53}$ Through Lucia's her physical onstage presence, she seems simultaneously divorced from her music in the scena, yet expressed by it. Lucia's vocal music, when it is eventually heard, is unable to 'mingle' with her accompaniment in the easy manner that Lucy's did.

The harp can also convey Lucia's nationality, as its role of envoicing becomes Lucia 'performed'. Francis Collinson identifies harps as the oldest of Scotland's three national instruments (the others being the bagpipes and the fiddle). As was noted in the

\footnotetext{
${ }^{51}$ Scott, The Bride of Lammermoor, p. 25. It is likely Donizetti and Cammarano were familiar with Scott's work in translation as by the time they were composing Lucia The Bride of Lammermoor had been available in Italy for a number of years and was published in Naples.

${ }^{52}$ Jerome Mitchell, The Walter Scott Operas, Birmingham: University of Alabama Press, 1977, p. 144.

${ }^{53}$ Mitchell's study is mostly concerned with tracing the changes between different operas based on the same literary sources. With this in mind, and his assertion that Donizetti has erased 'Scott's...Gothic atmosphere' (italics mine), it may be assumed he refers to the vision of the ghost described in the narrative, rather than particular musical evocations.
} 
previous chapter, there is nothing in Donizetti's score reminiscent of the bagpipes, but his use of the harp here is as much of an indication of setting as of Romantic and feminine sensibility. Consequently, the introduction is a point in the score where the Gothic setting and scenario merge in relation to the heroine. Therefore Lucia is not only communicating the setting through her already established nationality, but engages in establishing her own Scottishness through Donizetti's choice of instrumentation to accompany her first entrance in the opera.

The virtuosity of the harp exposes Lucia's predisposition to emotional excess. Significantly, it also highlights an equivalent contradiction between the physical and the other-worldly as Lucia's own voice. The harp is usually associated with the transcendence and the ethereal, especially for Romantics who used the Aeolian harp as a potent emblem of the inspired mind and the musicality of nature. The instrument's consistent association with heaven also conveys other-worldliness. Jeremy Day O'Connell comments that harp glissandi 'have come to serve as a sign of suspended reality, marking "flashback" or "dream" sequences'. ${ }^{4}$ Even though he relates this specific sound primarily to modern film and television music, where it is used as a cliché to frame a past or unrealistic event, the manner in which it operates as parody assumes origins or a longstanding tradition in more serious musical contexts. In the introduction to the cavatina this unearthly quality illustrates Lucia's hallucination - her encounter with the supernatural. As Lucia describes her hallucination, a dream-like occurrence from the past, the harp frames her Gothic episode, ending on a flourish at the end of the cantabile before the music turns to her love for Edgardo in the cabaletta and away from such explicit representations of the Gothic.

\footnotetext{
${ }^{54}$ Jeremy Day-O'Connell, Pentatonicism from the Eighteenth Century to Debussy, Rochester: University of Rochester Press, 2007, p. 157.
} 
Example 2.7: Scena, Act 1, scene 2 of Donizetti's Lucia di Lammermoor, bb. 27-42.
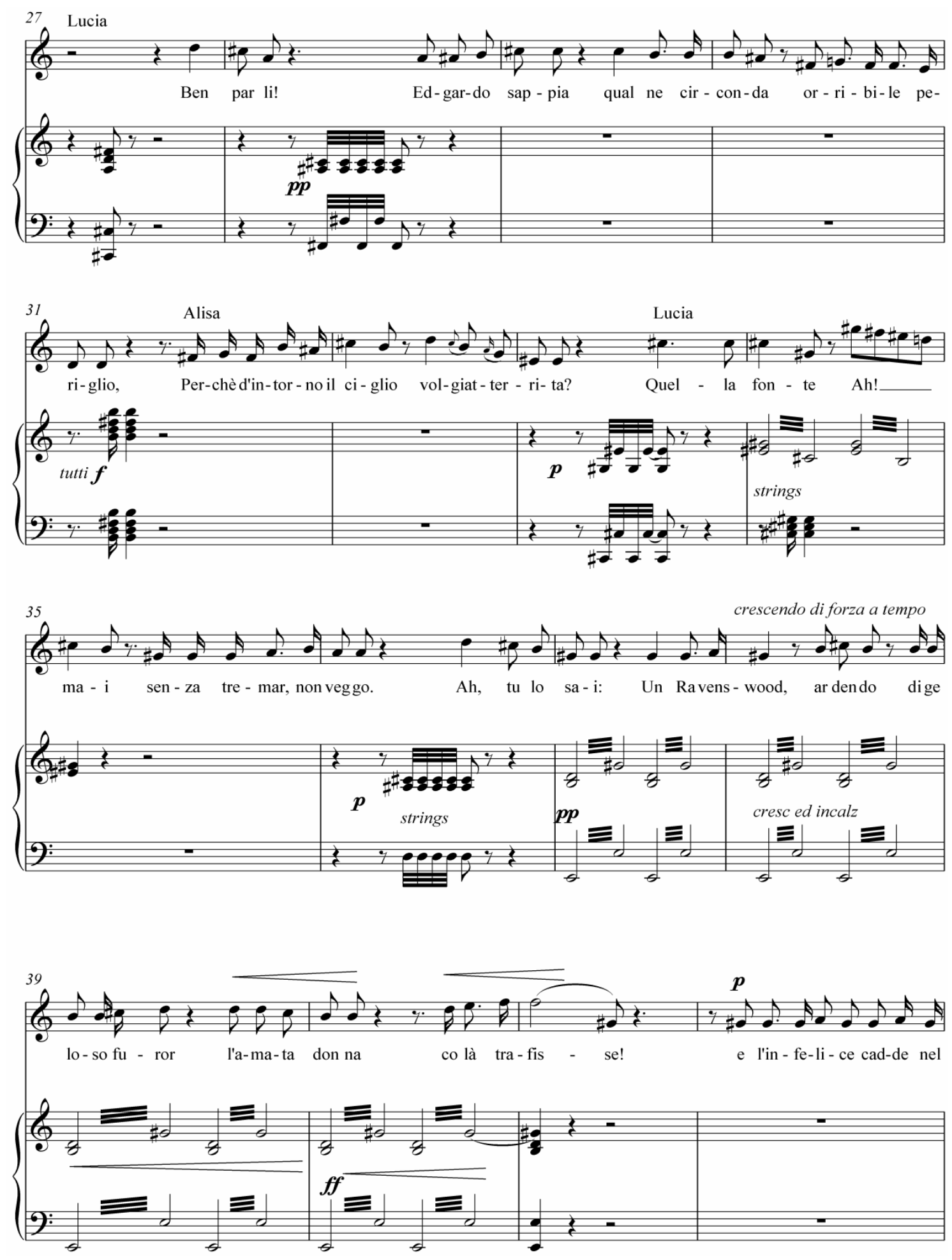

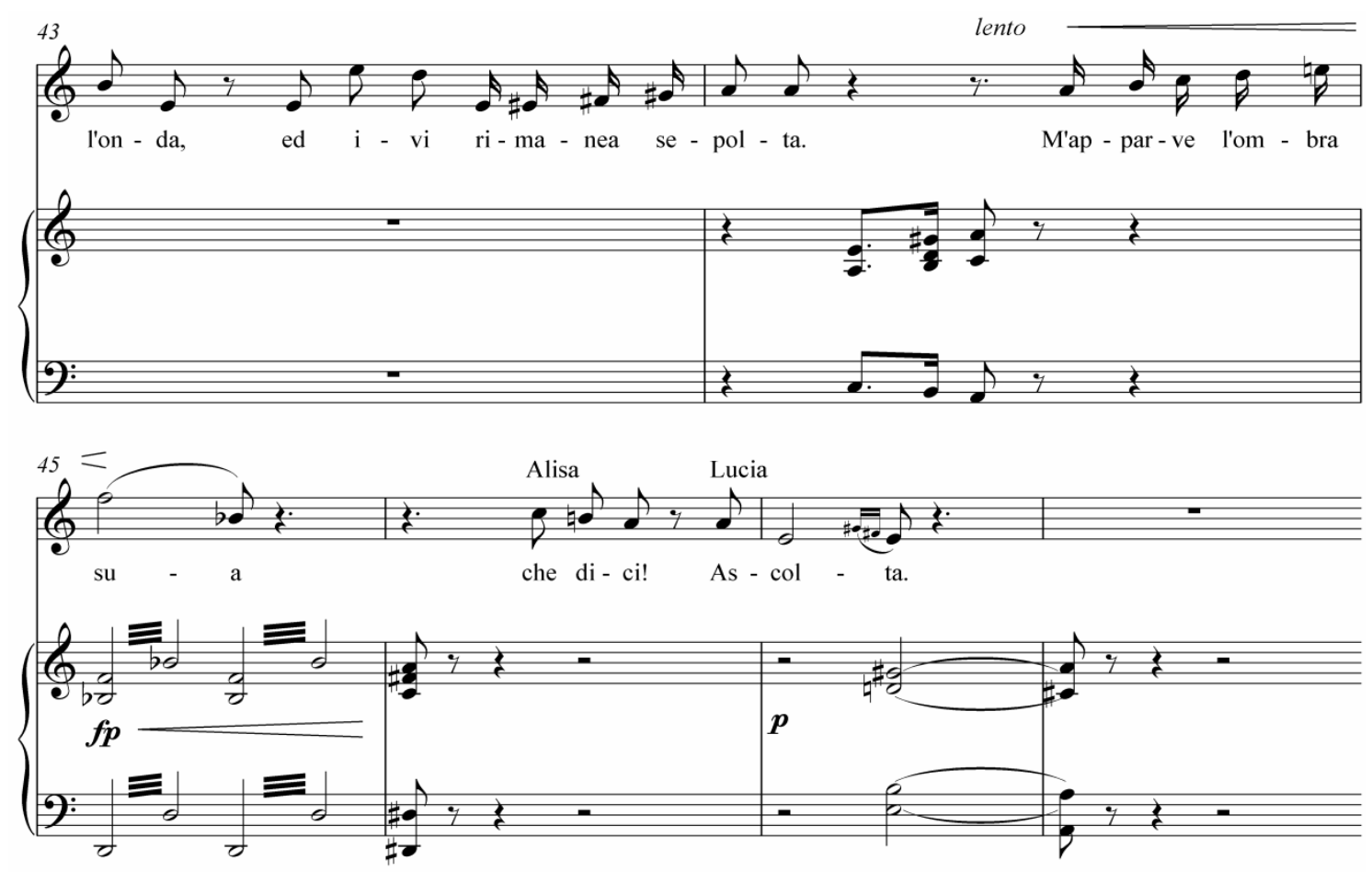

Paradoxically, though, in light of this heavenly and inspirational connection and the pleasant D major tonality of the introduction, the phantom that appears to Lucia is satanic. The ghostly woman acts as a harbinger of tragedy and casts her Gothic shadow over the rest of the opera. Transcending the physical realm therefore becomes an envoicing of Lucia's internal world, but at the same time, the virtuosity of the harp line draws attention to the physicality of the performer. Lucia becomes caught between the material and the metaphysical/supernatural integration in a scenario that echoes her own cognitive fluctuations between reality and imagination. On stage, she is represented physically, but the sound that embodies her and/or her vision - one is almost inseparable from the other at this point - remains part of the noumenal sphere. Lucia and Alisa do not appear to respond to the music as such until the beginning of the cantabile. 
The harp line ceases at Lucia's vocal entrance, which accentuates its power of envoicing; once Lucia sings in her own voice, the harp line is superfluous and the orchestral voice is used to emphasise her vocal line, continuing as the noumenal sound world. The accompaniment, predominantly of repeated chords in the pauses between the harp flourishes, continues in this way through Lucia's narrative. The music is more unsettled after Lucia's voice is heard. Before Lucia sings, the music shifts between the tonic of D major and its dominant, excepting very brief excursions through the dominant minor (A minor) and the dominant's relative minor (F sharp minor) (example 2.7). Although the minimal orchestral accompaniment is not unusual for the scena, Lucia becomes disconnected from its earlier music by her modulations (followed by the orchestra) through minor keys. The orchestra, in a more pronounced shift to F sharp minor, echoes Lucia's fear of the fountain. The string tremolos that Melina Esse notes as a 'topo[s] of the uncanny' reinforce the ghostly turn the narrative takes, as well as Lucia's physical trembling. ${ }^{55}$ While the accompaniment makes a listless attempt to return to D major, Lucia instead moves to A minor, and the trembling amplifies as she tells Alisa of the legend:

Un Ravenswood, ardendo di geloso furor, l'amata donna colà trafisse, e l'infelice cadde nell'onda, ed ivi rimanea sepolta. m'appareve l'ombra sua.

[A Ravenswood, burning with a jealous rage, stabbed the woman he loved over there.

The unfortunate woman fell into the water, where she remains buried.

Her ghost appeared to me.]

Her horror at the scene, foreshadowing her own death, rings in her voice, which centres around G sharp - the raised seventh of the tonality, and the tritone of the tonic key.

${ }^{55}$ Esse, 'Donizetti’s Gothic Resurrections', p. 93. 
It is doubtful at this stage of her cavatina that she is aware of, or can 'hear', her musical accompaniment. The last word she utters in her scena, however, is worthy of attention for how it changes the dynamics of the opera's sound world. 'Ascolta', Lucia sings, 'listen': in a customary launch for an aria addressed to another character, she invites Alisa, along with the audience, to hear of her vision, her experience with the supernatural intruder, and to delve into her internal world. After five bars of introduction, Lucia commences her cantabile.

Regnava nel silenzio alta la notte e bruna, colpìa la fonte un pallido raggio di tetra luna, quando sommesso un gemito fra l'aure udir sì fe', ed ecco su quell margine, l'ombra mostrarsi a me!

Qual di chi parla muoversi

il labbro suo vedea, e con la mano esanime, chiamarmi a sè parea; stette un momento immobile, poi ratta dileguò, e l'onda pria sì limpida di sangue rosseggiò!

[Silence reigned over everything in the depth of a dark night a dim ray of bleak moonlight struck the fountain, when I heard a stifled wail borne on the wind, and here at the edge of the fountain her ghost showed itself to me!

I saw her lips move as though she spoke, and with her lifeless hand, she summoned me to her; she stayed motionless for a moment, then she vanished, and the water, so clear at first reddened with blood!] 
In 'The Silencing of Lucia' Mary Ann Smart has noted Donizetti's unconventional treatment of the text in the cantabile. ${ }^{56}$ Nonetheless, this aria is more typical than the initial part of her mad scene in some respects; at the beginning of the mad scene, Lucia's apparent vocal freedom initially threatens to upset, or simply ignore, conventional formal boundaries. The stanzas of the cantabile are configured in what would usually indicate the strophic musical setting typical of a stage song or narrative aria. The music follows this in its 6/8 metre and accompanying arpeggios, while also adhering mainly to the conventional lyric structure of a double aria. But Donizetti's music does not repeat for each verse of the text as would be typical of a strophic setting. Rather it follows the narrative thread, only returning to the opening melody when it would be expected, at the end of the aria. Having characteristics of both strophic form and the conventional lyric prototype highlights the disruption the ghost, and with it the past, causes for Lucia. Smart's observations about the ambiguous form of Lucia's aria have interesting implications for how we read the 'ghost narrative', as it disturbs the typically orderly operatic world. In this scene by the fountain we stand to lose some of the typical reflective nature of an aria's slow movement, as Lucia is unable to close her mind to her vision, a narrative of the past which, unable to be confined, violates her present. Strophic form is commonly used for stage songs and narratives in operaphenomenal songs that are self-consciously 'performed' to the audience onstage as well as the offstage audience. These strophic stage songs are typically static forms in which neither plot progresses nor characters develop in the present to any great extent. Paradoxically, strophic songs often have great progression of plot and characters within the story being narrated. Therefore the ghost - an intrusion from Lucia's past - is actively developed, while Lucia is static, frozen in terror.

\footnotetext{
${ }^{56}$ Smart, 'The Silencing of Lucia', pp. 133-4.
} 
Lucia's introduction of 'ascolta' heightens her (and the audience's) awareness of the operatic sound worlds, as Lucia is able to externalise her inward thoughts and experience (she is the only one to envisage the phantom) through the orchestra. Under the postulation that the orchestra can represent the unseen or invisible, Lucia's otherworldly episode becomes visible to those around her and the audience. Yet in a twist, Abbate notes that while characters may be aware of their own singing voice, they may still be oblivious to any musical accompaniment. ${ }^{57}$ For them, their internal thoughts, taken up by the orchestra in the role of translator or exposer, remain part of Abbate's noumenal, against their own phenomenalism. ${ }^{58}$ Smart's comment that the story is active in Lucia's past rather than the present - one of the features that is at odds with interpreting the aria as entirely in lyric form, which typically deals with changing emotions in the present - is verified by Abbate's scrutiny of time in a phenomenal song. Abbate proposes that 'any operatic narrative...creates such a node, a layering of time, in which real elapsed time, the time it takes the performer to perform, is laid over the time represented by the narrative.' In 'Regnava nel silenzio', these layers of time are further confounded. History is recalled by memory and the past veils the present. What is more, the cavatina's present intrudes into the future of the mad scene in an altered motivic form; all of which serve to dramatise the unstable effect the Gothic constructs around Lucia.

However, whether Lucia's cantabile can mark a point where the noumenal realm is approached is determined by musical features. Recurring motives in the orchestra, and the orchestral doubling of Lucia's (and sometimes other characters') transcendent vocal line emphatically enunciates a Gothic tone. Additionally, the Gothic is evoked by

\footnotetext{
${ }^{57}$ Abbate, Unsung Voices, p. 123.

${ }^{58}$ It is perhaps easier to imagine the orchestra as representing these other realms of the operatic world in modern performances, suck into the pit, instead of their nineteenth-century position, visible in front of the stage.
} 
Donizetti's unconventional formalistic tactics: unexpected tonal relationships, the use of particular (usually dissonant) intervals to underline a thematic discordance and his adhesion (or not) to Italian lyric form. Melina Esse describes a 'particular nonchalance' of much of the music which might be expected to embody the Gothic more obviously, highlighting how frequently Italian operatic conventions supplant any affinity between the scenario and the music. ${ }^{59}$ Indeed, the major mode of the harp line is strikingly disjointed from her tormented actions. This musical and textual disconnection is already evident through Donizetti's use of the Scottish-Gothic context, which is represented through a disjunction between musical symbols of the country - 'cheerful Scottish style' - despite the doom-laden text or situation depicted in the libretto. Notwithstanding the setting-based Gothic of Lucia, in 'Regnava nel silenzio' we contend with a multiplicity of musical interpretation, which is sometimes far from nonchalant in its expression of the Gothic. ${ }^{60}$ Lucia's exploration in feminist terms, as resisting the male constraints within which the prima donna exists, as Smart and McClary explicate, seizes on much of what could also be read as enhancing, or even creating the Gothic and the 'other-worldly'. Despite this variation of agenda, the crucial place of women, as the pivot chord between Gothic studies and opera, denotes that the musical 'excess' those traces of madness and female sensibility are therefore also an integral part of the Gothic.

The cantabile begins with a shift to the parallel minor of the introduction and scena, D minor. This is appropriate for the two short phrases introducing Lucia's melody, which both intimate the downward sighing pattern mentioned by Esse as a

\footnotetext{
${ }^{59}$ Esse, 'Donizetti's Gothic Resurrections', p. 81.

${ }^{60}$ Ibid.
} 
prevalent Gothic signifier. ${ }^{61}$ The phrase verbalises the body and its involuntary expression of horror. The vocal line begins with an ascending minor sixth, but the melody descends gradually over the next two bars, in a mournful stepwise motion. The arpeggios in the clarinet, while a typical accompanying figure for arias, also evokes the stasis of the Gothic intrusion and her brooding obsession with the phantom (example 2.8). While the opening phrases of the aria lack the initial embellishments of her other numbers, as the music continues, the orchestra beneath her becomes less involved as her coloratura, tempo and pitch escalate. The flute doubling of Lucia's vocal line is increasingly present in the cantabile. It suggests Lucia's awareness of the Gothic intruder as it floats in and out of her melody mid-phrase, like a ghost itself, becoming a concrete expression of the noumenal surfacing from the orchestral voice.

As Donizetti employed typical displays of coloratura in the majority of his works during the late 1820s and 1830s (often under duress from the leading soprano herself), coloratura cannot alone be seen as a potent signifier of disturbed reality and heightened emotional excess. ${ }^{62}$ It is not used unusually until its exaggerated form in the cabaletta of the mad scene in Act 3, which intensifies the disturbing musical features of the cavatina by quoting it as a musical memory for Lucia. Other factors must accompany her vocal pyrotechnics in reaching toward a noumenal limit. The particular associations with the feminine and the Gothic are seen together in the mimetic 'painting' of words or phrases of the text. Usually related to Lucia's vision - and thus the Gothic - they are reinforced by brief flights of vocality, as on the word 'margine', 'edge' or by heavy accents, such as on 'l'ombra mostrarsi, 'the ghost showed itself to me'. As the instructions call for Lucia to cover her face with her hands - comprendosi

\footnotetext{
${ }^{61}$ The descending interval is also crucial to Tomlinson in his discussion of Macbeth's 'tutto è finito' motive.

${ }^{62}$ See Smart, 'The Silencing of Lucia', p. 128; McClary, Feminine Endings, p. 93.
} 
il viso colle mani - and become more distressed, the flattened notes describe her horror at what she sees and the coloratura becomes more elaborate, culminating on the words 'the water turned crimson with blood'.

Through her gestures, the visual representation of horror is connected to the music through Lucia's body and places her on a trajectory from mental delicacy and instability to full-blown hysteria. Lucia's experience of hallucination is envoiced by the flute. It is this stirring between the internal and external mind and physical existence which creates an uncanny Gothic mood. Covering her eyes implies the ghost is an external presence (at least for Lucia); she must literally cover her eyes to avoid seeing its physical form. But at the same time, the orchestra 'paints' her hallucination through sound so that those who cannot see it (Alisa and the audience) can certainly hear it, remembering that they have been instructed to 'listen'. The ghost's literal presence remains, for Alisa and the audience, internalised in Lucia's psyche. That the flute echoes Lucia's vocal line, especially in places where the ghost's physical form is described, gives it phenomenal existence for Alisa and the audience. However, it enters mid-phrase, six bars after Lucia's melody, which upsets this phenomenalism. It is somewhat ambivalent, but when Lucia instructs Alisa to listen, she is referring to listening to her own vocal line, not her accompaniment which, obsessed by literally 'seeing', she remains oblivious to. The music is thus subordinated to the phantom's physical presence and seems never to quite breach the noumenal limit to enter into a completely conscious phenomenal for Lucia. Therefore the Gothic is evinced by the interplay between the sounds and gestures of Lucia's nightmarish vision. By the time her coloratura becomes more emphatic at the end of the cantabile, the ghost has vanished and so has the sound of the flute, only to be replaced by harp flourishes, which reiterates its envoicing role in the introduction. Moreover, the closing phrases of the 
cantabile are a particularly uncanny moment. The return to the initial melodic material of the cantabile - the A section in formal terms - usually calls for a return to the tonic key. Consequently, Lucia sings of her horrifying sight to a major tonality.

Example 2.8: 'Regnava nel silenzio', Donizetti's Lucia di Lammermoor, bb. 58-95.
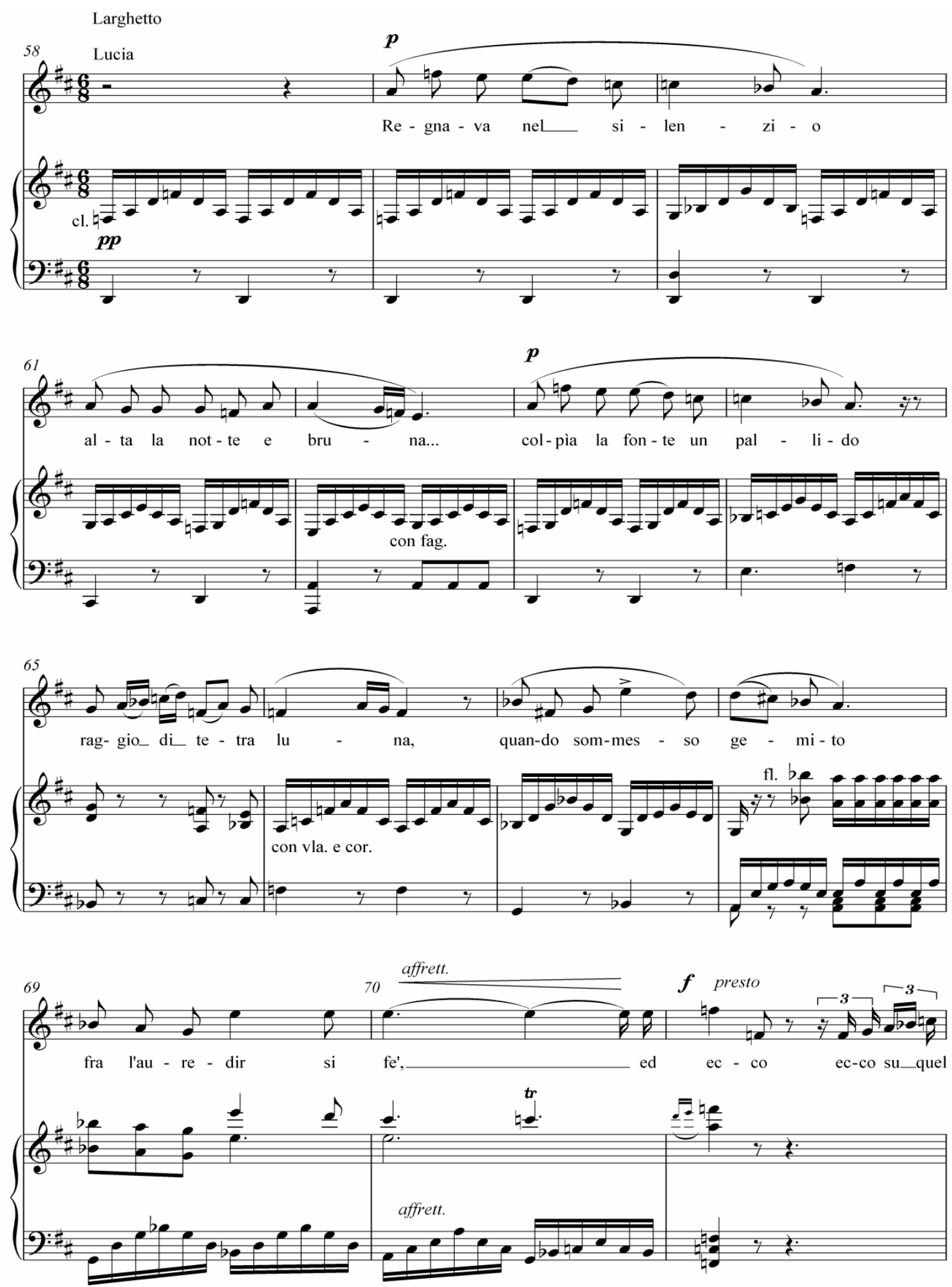

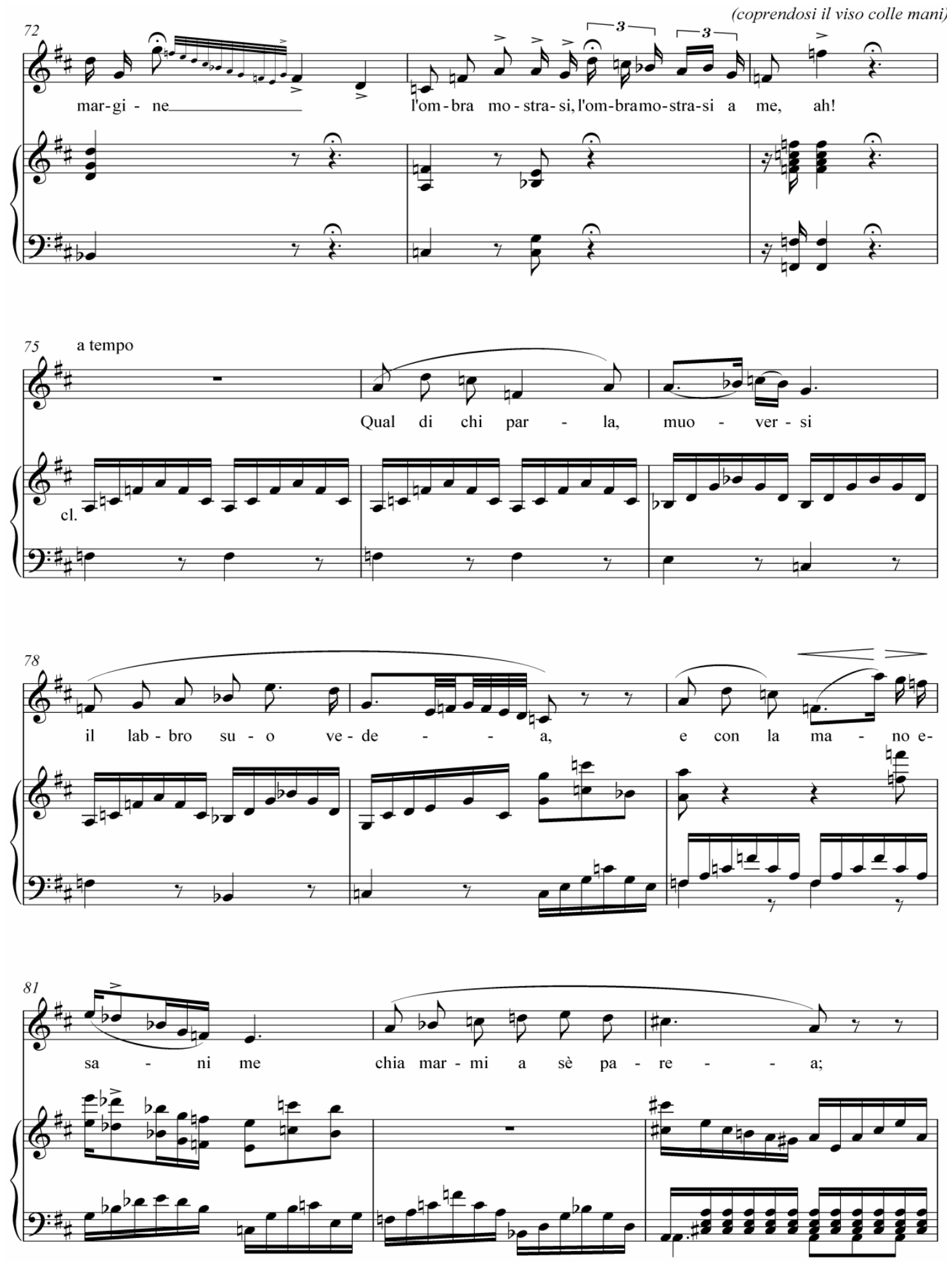

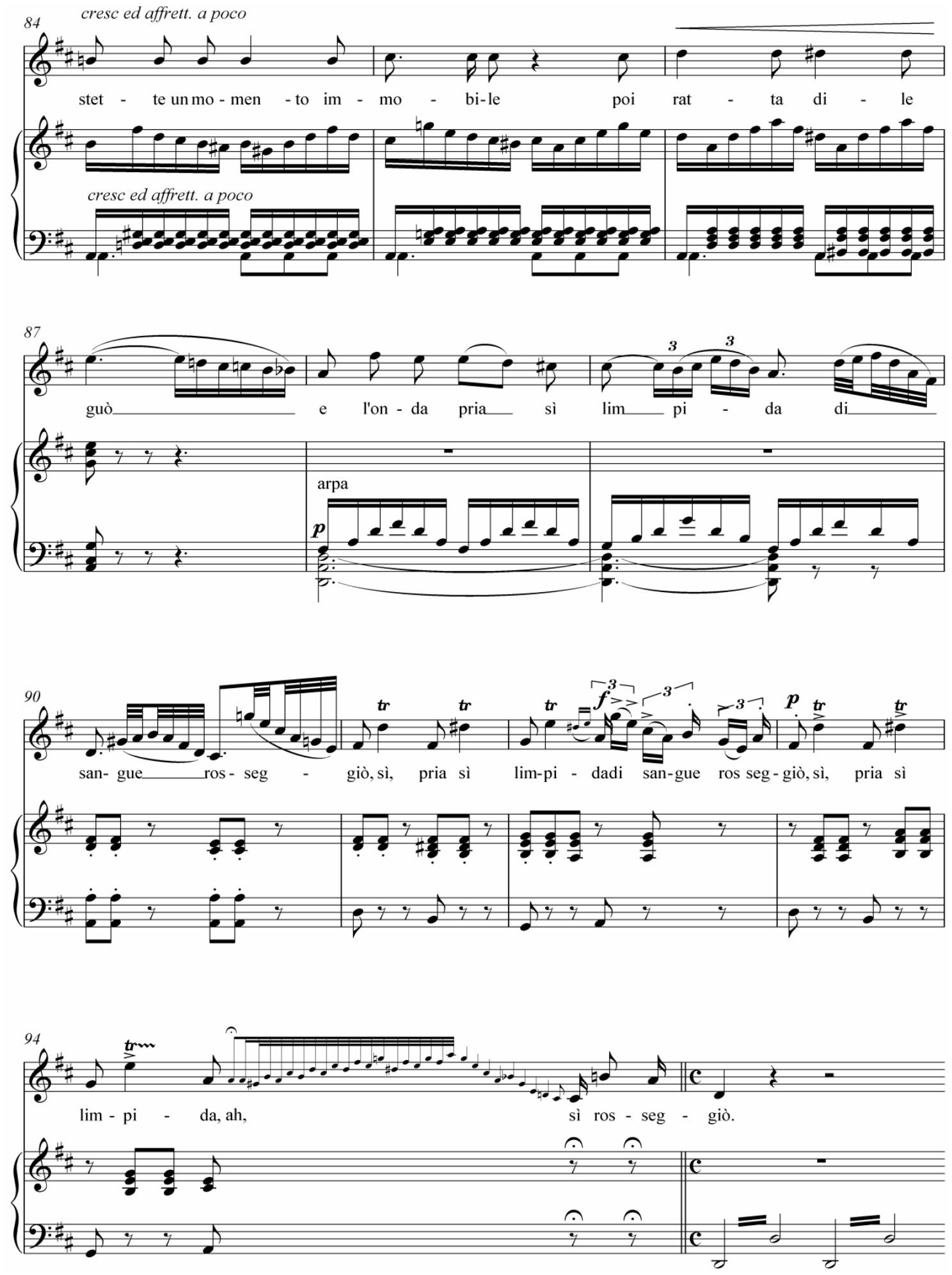
The separation between text and music is most unsettling. In effect, this later musical quotation is a memory doubly removed from Lucia's physical 'reality'. She retreats further and further into her subconscious, while simultaneously commanding her physicality through the increasing virtuosity of her voice. The spectral nature of Lucia's memories is illustrated through her physical presence in the form of a Gothic supernatural embodiment.

Taking heed of Scott's novel, Cammarano emphasises the historical continuity of the myth of the Ravenswood victim when he has Lucia announce that Edgardo has not yet arrived at the fountain. It is their meeting place, as it was for the Baron of Ravenswood and his victim long ago. The tempo di mezzo following the cantabile is brief, and Lucia returns to the present. Although she is free of her hallucination, her emotionalism persists. But now she is focused on her love for Edgardo, and this transition from the other-worldly to her amorous outpouring still renders her susceptible to the Gothic undertones of doomed romance. The cantabile, which is fundamental in creating the opera's Gothic tone, has little effect on the dramatic path of the opera (instead, the slow movement has a considerable role in characterising Lucia's development, or perhaps more appropriately, demise). Alisa puts Lucia's vision down to the emotional torment she is experiencing by loving her family's enemy: 'Lucia, desisti da un amor così tremendo' ['desist from a love so terrible']. Certainly, Lucia comes to the fountain in the first place to meet with Edgardo: present love has more impetus than fear of the past. This dramatic shift from intense terror to joy underpins her mental fragility, thus she is never truly free of her supernatural experience.

The flute introduces the melody of the cabaletta, continuing its envoicing. Instead of a separation between Lucia and the orchestra, it implies she will be more in synch with her accompaniment than her vocal line suggested in the cantabile. The flute 
functions in the same way as it did in the cantabile, emphatically echoing her vocal line on emotive words such as 'estasi', 'adore' and 'core' ['ecstasy', 'adoration' and 'heart'] in the first articulation of her melody. However, in the cabaletta there is no discordance between Lucia's internal and external realms, or the past and the present. Whereas the flute seems to envoice Lucia's experience in the cantabile as phenomenal for Alisa and the audience, the separation between the flute and her voice diminishes in the cabaletta when there is no anxiety of recollection.

Example 2.9: Lucia fails to adhere to the form of the music in her melodic repeat of the 'A' section material, 'Quando rapito in estasti', Act 1, Lucia di Lammermoor, Donizetti, bb.129-34.
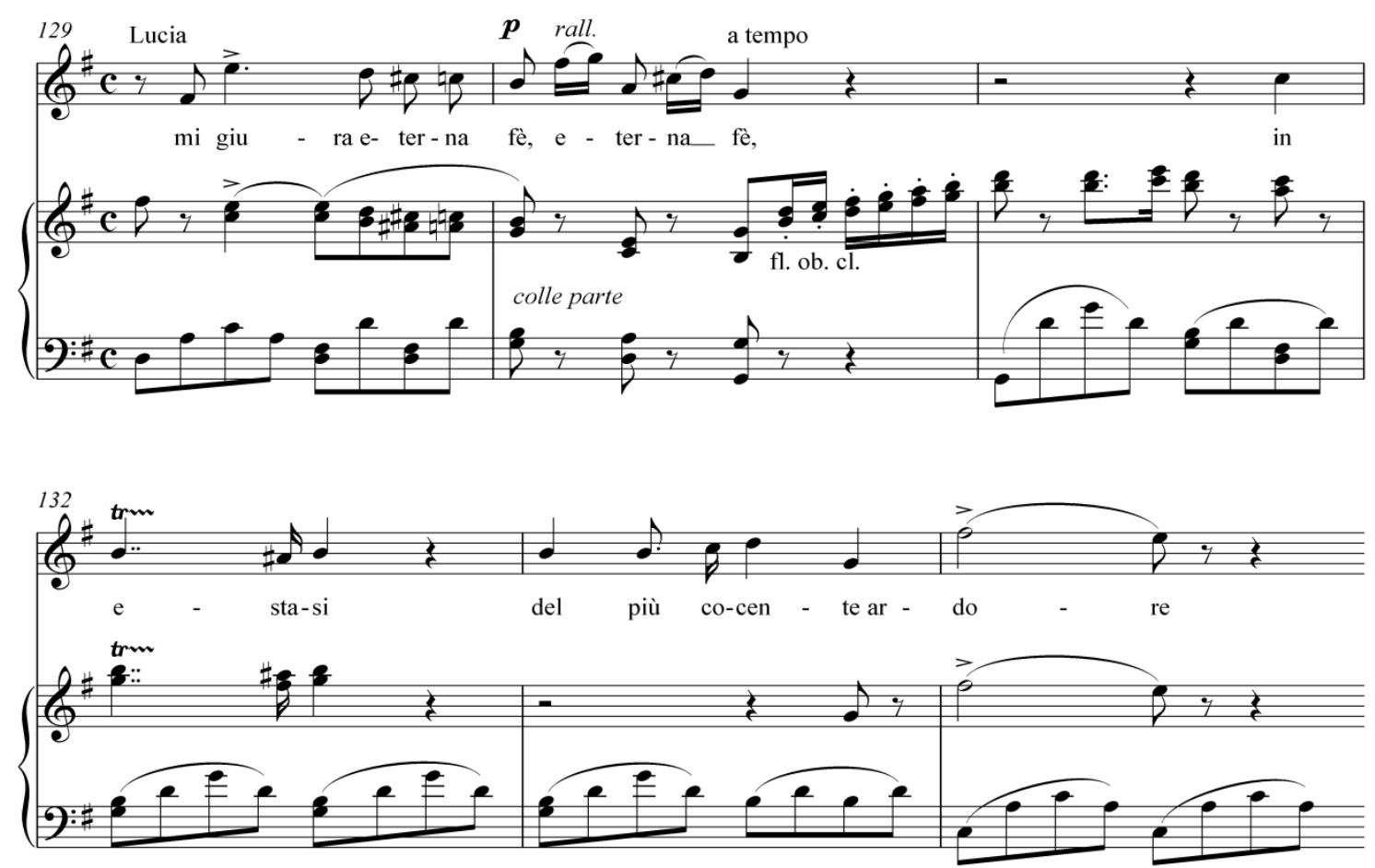

The 'listening' has been broken by the tempo di mezzo (and its subsequent shift to the present as Lucia finishes her tale), and also the change of musical mood. The only hint of her vision is when the music shifts to the dominant minor ( $\mathrm{D}$ minor), recalling the key of her cantabile while she explains that when she is with Edgardo 'gli affanni [suoi] 
dimentic[a]' ['she forgets her preoccupations']. However, it is also conventional to modulate in the B section, and this phrase marks its expected new melodic material. Lucia's late entrance to the melodic repeat of the A section further conveys the musical noumenalism and that Lucia is caught up in her own fancy, oblivious to her musical sound world (example 2.9).

'Quella voce m'é qui nel cor discesa'63

In Act 2 of Lucia di Lammermoor, Lucia's hope to marry for love is beaten out of her by her brother, who uses her to make an advantageous financial and political allegiance. Raimondo is no help to her, corroborating Enrico's story against Edgardo's faithlessness and urging her to sacrifice herself for the sake of her family - her brother's fortune and her dead mother's pride. Lucia's demise is expressed by those around her. In the scena of the cavatina, Alisa asks her 'Perchè d'intorno il ciglio volgi atterrita?' ['Why do you gaze about aghast?']; then in the first scene of Act 2, Raimondo exclaims that she is delusional ('Tu pur vaneggi!'). The libretto instructs Lucia to almost swoon when she is given the letter by Enrico, and she then collapses in a faint at Edgardo's arrival in Act 2. These remarks and her own actions allude to Lucia's mind undergoing a more gradual mental decay than the 'snap' McClary, and others, have attributed to her signing of the marriage contract. If anywhere is a snapping point though, it is the murder of Arturo, a hot-blooded act of desperation, but one which does not occur visibly on the stage. The onstage death is saved for Edgardo in the final scene. Through killing Arturo it is as if Lucia confounds Arturo and Enrico as a single symbol of male oppression, past and present. Especially as Arturo pronounces on his arrival

\footnotetext{
${ }^{63}$ ['That voice has sunk into my heart']
} 
that he will be 'amico, fratello e difensore' ['friend, brother and defender'] and his words are then intensified as the chorus repeats them. Furthermore, Lucia's method for murder is eerily similar to the exaggerated, figurative way Enrico says Lucia will 'kill' him by refusing to wed Arturo: 'tu la scure appresti a me. / Ne' tuoi sogni mi vedrai, ombre irata e minacciosa! / Quella scure sanguinosa starà sempre innanzi a te' ['you ready the axe for me. You will see me in your dreams, an irate and threatening ghost! That bloody axe will always stay before you'].

The stretta of the Act 2 finale, 'Esci, fuggi il furor che accende', is certainly an uncanny moment in the opera. Edgardo sings:

Tracidatemi e pronubo al rito sia, lo scempio d'un core tradito.

Del mio sangue coperta la soglia;

dolce vista per l'empia sarà!

Calperstando l'esangue mia spoglia all'altare più lieta ne andrà!

[Kill me and let the destruction of a betrayed heart preside over the wedding. Cover the threshold with my blood, it will be a sweet sight for the wicked woman! Trampling upon my bloodless remains she will not go to the altar more gladly!]

While Lucia sings simultaneously:

Dio, lo salva, in sì fiero momento d'una misera ascolta il lamento. È la prece d'immendo delore, che più in terra speranza no ha. È l'estrema domanda del core, che sul labbro spirando mi sta!

[God, save him, in such a cruel moment, listen to the lament of a wretched woman. It is the prayer of immense sorrow, that has no more earthly hope. It is the final request of my heart, that passes from my lips!] 
The Gothic associations Edgardo conjures with his words - blood, misfortunate marriage, death, human remains and a wicked woman - sit in stark disjunction with Lucia's appeal for divine intervention. They both sing to the tune Enrico, Arturo, Normanno and the male chorus has already begun the stretta with, in which they predict 'ma fra poco più atroce, più piero / sul tuo capo abborrito [di Edgardo] cadrà' [but soon something more dreadful and cruel / will fall on [Edgardo's] detested head']. While Lucia and Edgardo sing the same melody, the others are silent, or when they do sing, all sing to a version of the melody that is altered in some way to Lucia and Edgardo's (example 2.10). The effect of this is to accentuate the tie between Edgardo and Lucia that the text would seemingly deny. This scene was cited as a crowning moment of the opera after Lucia's Naples debut and was also noted as a high point of the opera in France and England. It is a moment of musical supremacy, where the audience is swept away by the music - it is precisely the same situation from which Clément launches her study of the forgotten accompanying texts. The words are obscured by other words, as the music moves, vivace, in a type of organised chaos. From the Più allegro section, everyone sings mostly in rhythmical (though not melodical) unity, further obscuring the text and emphasising the power of the music. Thus Cammarano's Gothic text is swamped by the Italian operatic conventions that render the music void of Gothic signification.

Nevertheless, the musical Gothic is once again configured the next time Lucia enters the stage, for her mad scene. Lucia's mad scene has long been considered the climax of the opera (although this was not always the case). A number of musical evocations of the Gothic carry from Lucia's cavatina to her final moments, most obviously through her altered state of mind. 
Example 2.10: Lucia and Edgardo's vocal melody, Act 2 finale, Lucia di Lammermoor, Donizetti, bb. $132-9$.

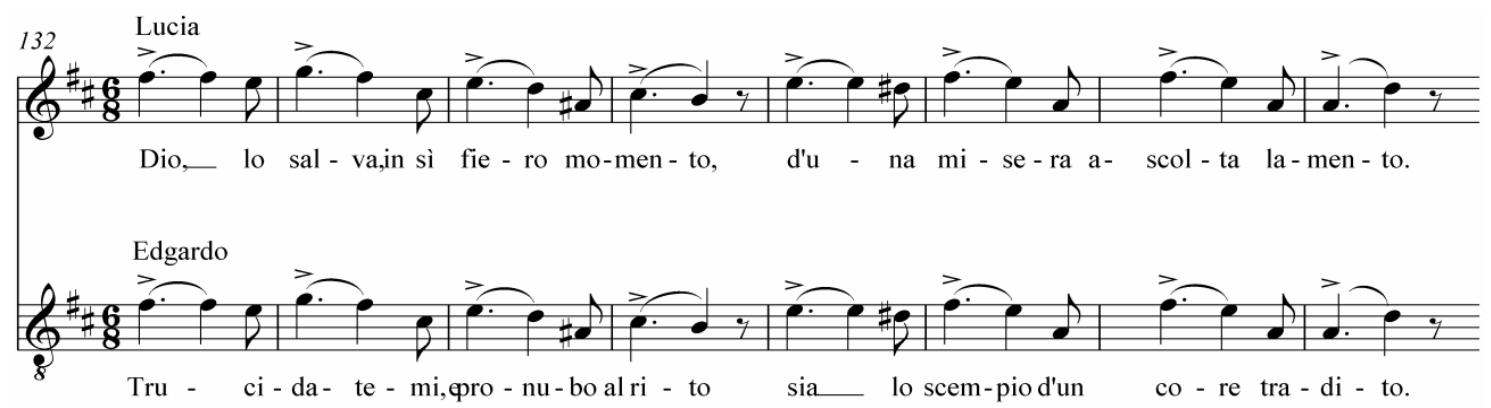

Her appearance after committing mariticide, dressed in a white gown covered in blood, also conveys the scene as Gothic, although her musical representation begins before she is visible. The flute echoes through Raimondo's description of her bloody hands and her vacant, fixed gaze. Her broken mind is once again associated with the fragile sound that will return, unnervingly, in her cadenza. However, it does not act in the same phenomenal way for the audience (or the chorus) as the flute did in the cantabile. It is not a concrete representation of Lucia's mind - even though it is fractured, failing to perform a complete phrase and drifting in and out of the orchestral voice. The first time it sounds in Raimondo's aria is over the words 'vicino a morte' ['near to death'], which although referring to Arturo - whom Raimondo has heard a final dying cry issue from - is also true of Lucia (example 2.11). A repeated motive accompanies Raimondo's description of Lucia clutching her husband's bloodied dagger. Now accompanied by the clarinet, the flute provides the only melodic accompaniment to Raimondo's own vocal line. Their melodic appearance at the end of the aria is even more unsettling because at this point Raimondo is repeating his final phrase 'delle mente la virtude a lei mancò! [her virtuous mind is lost to her!], and his orchestral accompaniment is lacking in melody. Donizetti instead underpins his dramatic 
narrative aria with recitative-like accompaniment - repetitive rhythmic figures in the strings.

Example 2.11 Raimondo's aria, Act 3, Donizetti's Lucia di Lammermoor, bb. 19-31.
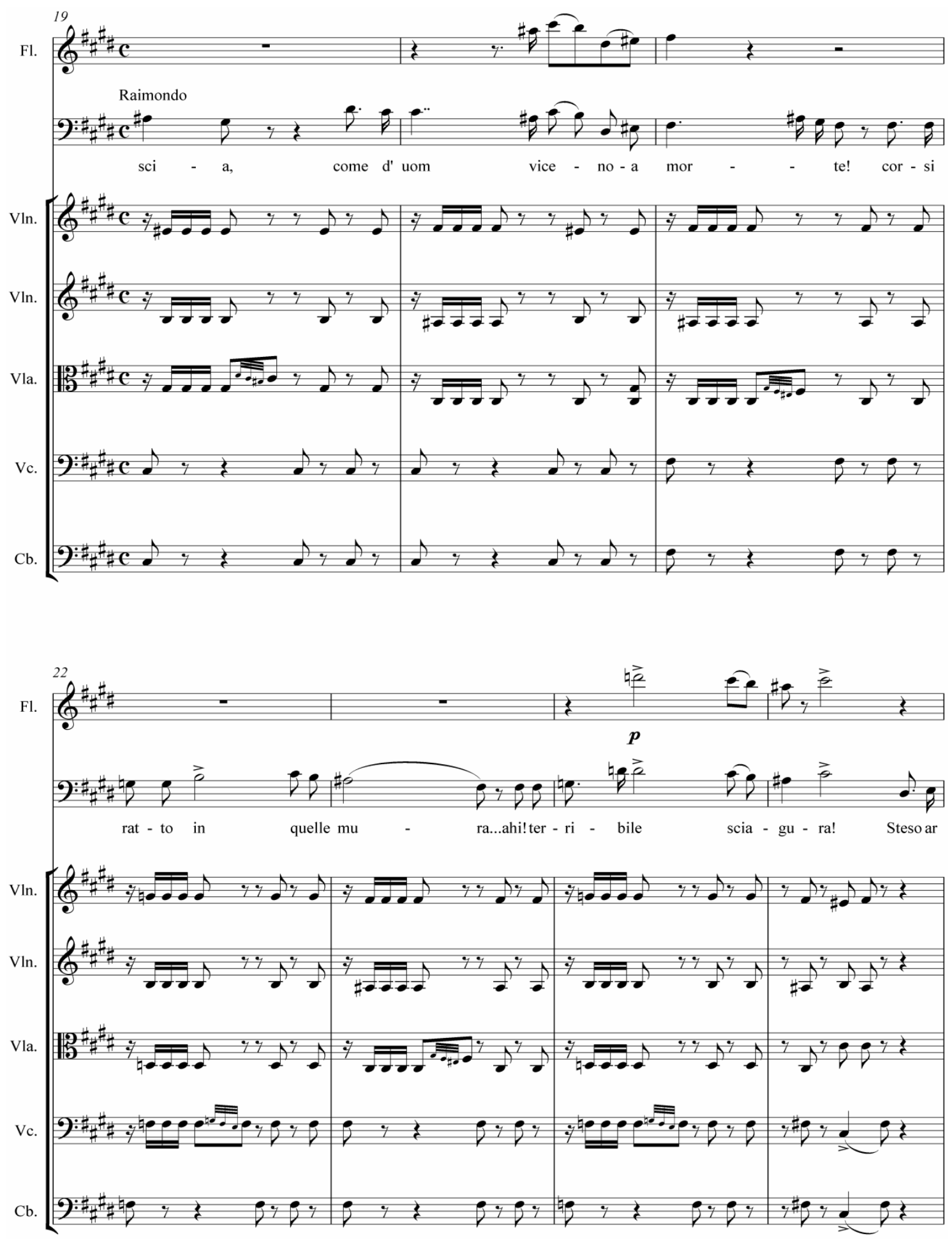

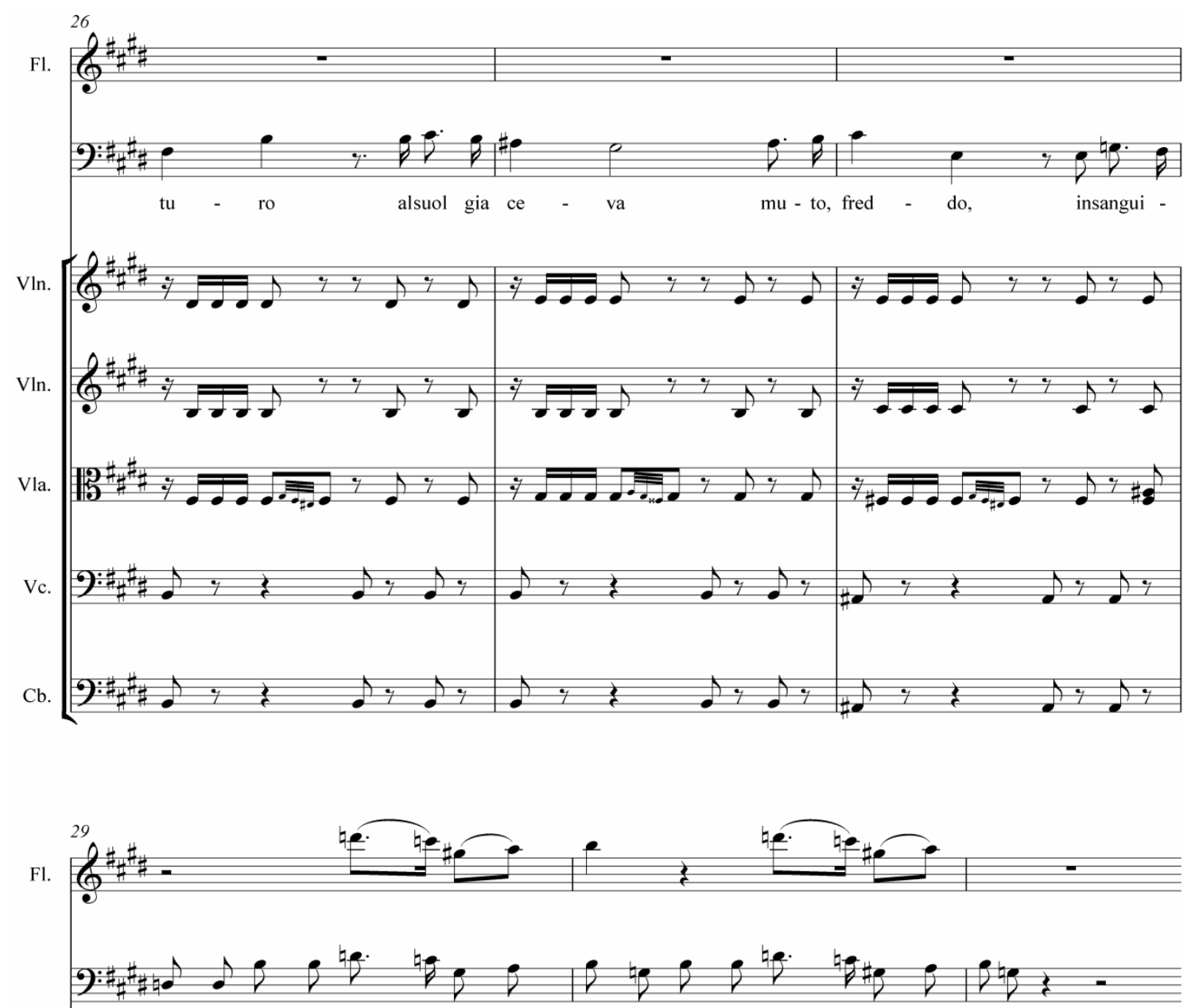
-na - to!.. e Lucia l'acciar stringe - va, che fu già del tru - ci - dato!...

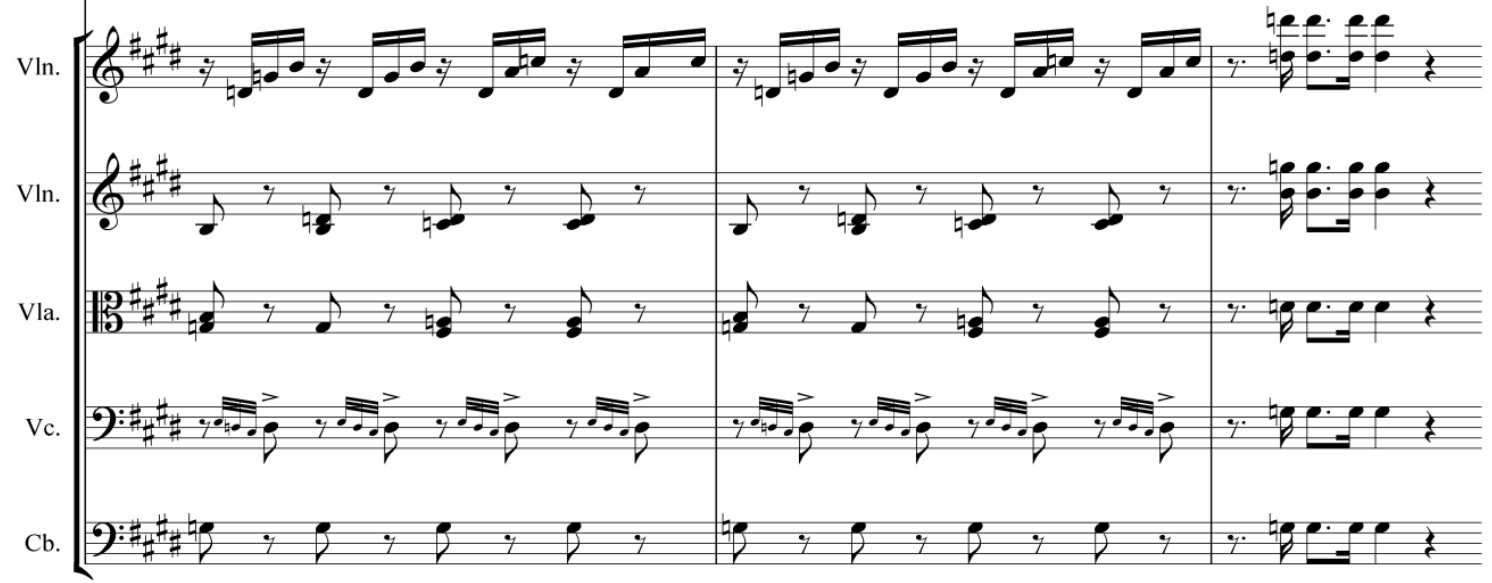


If Raimondo was not so distressed over what he has witnessed in the bridal chamber, his aria would have taken a strophic form, for as he moves from setting the scene to his entrance into the room and the sight that befell him, his music loses the quality of an aria. He is reduced to declamation as the strings musically paint his horror with their trembling. The celli, sounding repeated notes with appoggiature, seem frozen in fear and the orchestral block chords are ominous, a stabbing from the sparse orchestral voice.

The discovery of the incoherent Lucy in The Bride of Lammermoor is markedly different from Raimondo's discovery of Lucia, who is able to articulate for herself within her own operatic language, empowered, rather than reduced to a quivering wreck in the corner. Scott's Lucy is discovered alone in the dark, rather than standing over her victim:

One of the company, holding his torch lower than the rest, discovered something white in the corner of the great old-fashioned chimney of the apartment. Here they found the unfortunate girl, seated, or rather crouched, like a hare upon its form - her head-gear dishevelled - her night-clothes torn and dabbled with blood - her eyes glazed and her features convulsed into a wild paroxysm of insanity. When she saw herself discovered, she gibbered, made mouths, and pointed at them with her bloody fingers, with the frantic gestures of an exulting demoniac...she looked down, and uttered the only articulate words that she had yet spoken, saying, with a sort of grinning exultation, - "So, you have ta'en up your bonnie bridegroom." 64

In this passage Lucy is irrational and has lost control of her ability to communicate in her usual manner: she is incomprehensible and unpredictable. Her reversion to the Scottish accent for her final words depicts her as 'other', associating her with the lower class characters Scott habitually gives accented speech to in the novel. Lucy is reminiscent of Shakespeare's Ophelia not only in typical 'mad' attire, but also in her altered voice, for Ophelia degrades herself by singing crude popular songs to the queen.

${ }^{64}$ Scott, The Bride of Lammermoor, p. 260. 
Their social display is the ultimate sign of insanity. Yet Lucia's music negates any insanity-driven assertiveness the audience may imagine from Raimondo's account of the scene in the chamber. Rather, Lucia's entrance, amid a cry of 'dalla tombe uscita!' ['she rose from the tomb'], is announced musically by the eerie and fragile flute line (example 2.12).

Example 2.12: Lucia's mad scene entrance ('Ardon gl'incensi'), Donizetti's Lucia di Lammermoor, bb. 728.

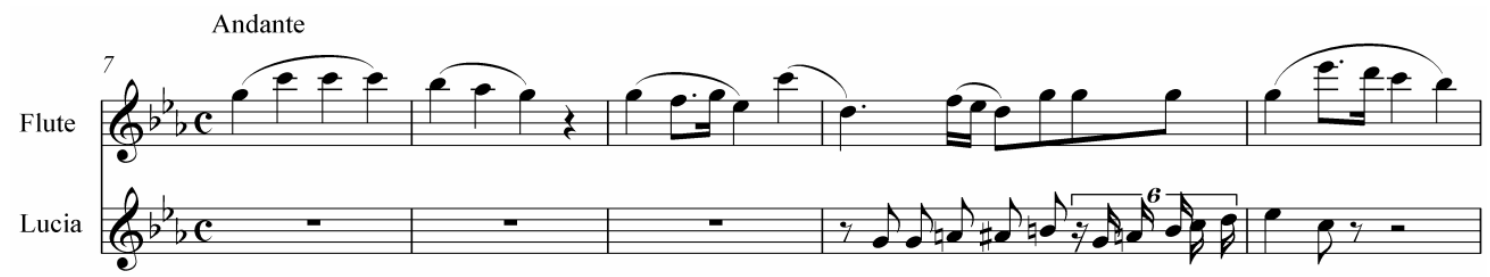

Il dol-ce suo-no micol-pìdisua vo- ce!...
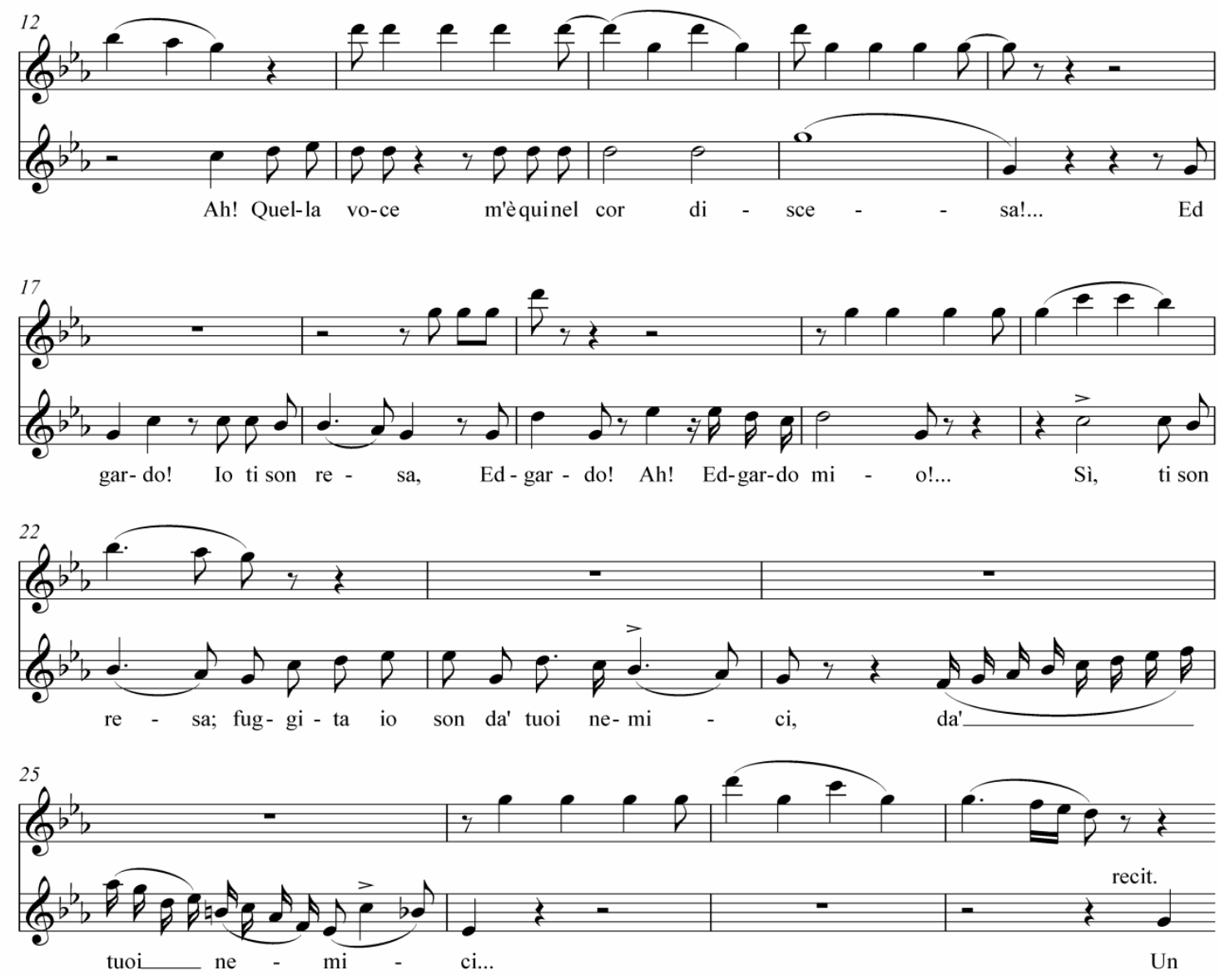
It is here that Donizetti had originally intended to use the glass harmonica, its fractured sound an audible allegory for Lucia's mind. This was changed to the flute before the premiere, perhaps, as Annalisa Bini and Jeremy Commons suggest, because it was too difficult to find a player, or because the sound would have been lost in the theatre. ${ }^{65} \mathrm{~A}$ number of scholars have remarked that the instrument's 'uncanny' timbre is appropriate for evoking Lucia's madness. ${ }^{66}$ Nonetheless, in her study on women and glass harmonicas, Heather Hadlock clearly shows the instrument would have summoned not only associations of madness, but innumerable other, often contradictory, insinuations for a nineteenth-century audience. According to Hadlock:

In the first decades of the nineteenth century the instrument emerged as a Romantic literary icon of inspiration, other-worldly voices, and esoteric knowledge. It figured prominently in Romantic fiction and poetry as the sublime voice of ethereal, superhuman realm...But at the same time it lost its prestigious place in musical practice as musicians, unlike poets, grew disenchanted with its "ethereal" echoes and its feminine association. ${ }^{67}$

The glass harmonica shares many Romantic qualities with the Aeolian harp, an instrument the extended harp solo in the introduction of Lucia's cavatina may allude to. Like the harp, it can be linked with notions of femininity and in Lucia both instruments participate in her envoicing. Hadlock explains that the late eighteenth-century (certainly idealised) view was that as the glass harmonica required little physical motion to play, listeners were not aware of the physicality of either the instrument or the music-making process, as was the case with other instruments; hence the 'other-worldly' tones and suitability for women, who were encouraged to play instruments that required only a soft touch. It was also the instrument most closely aligned with the female voice by writers at the time of its prominent use in the late eighteenth and early nineteenth

\footnotetext{
${ }^{65}$ Annalisa Bini and Jeremy Commons, Le prima reppresentatazioni delle opere di Donizetti nella stampa coeva, Milan: Skira, 1997, pp. 520-1.

${ }^{66}$ Including Smart, 'The Silencing of Lucia', p. 129 and Heather Hadlock, 'Sonorous Bodies: Women and the Glass Harmonica', Journal of the American Musicological Society, Vol. 53, No. 3, 2000, p. 534.

${ }^{67}$ Hadlock, 'Sonorous Bodies: Women and the Glass Harmonica', pp. 508-9.
} 
centuries. ${ }^{68}$ Additionally, Hadlock describes the 'anecdotes' told by Karl Leopold Rollig in his 1787 treatise Über die Harmonika, ein Fragment about the effect performances on the glass harmonica had on its audience in various places. One setting is a mysterious Gothic castle, which 'develops the glass harmonica's occult connections and credits it with bringing a dead or near-dead man back to life' ${ }^{69}$ The chorus and principals sing in the Act 2 finale that Lucia is poised half-way between life and death. The sound of the glass harmonica in Lucia follows the pattern of the instrument's constant contradictory effects Hadlock outlines; the sound does not revive Lucia or heal her mental distress. As the glass harmonica can express joy as easily as terror, it is just as likely to act as a stimulus for death as for life.

When Hadlock discusses Lucia's relationship with the glass harmonica, she explains that the glass harmonica performs in her celebrated cadenza. While this is true of the few modern recordings where the instrument has been reinstated, for all performances until Nelly Melba's 1889 performance of Lucia in Paris, the cadenza did not feature the voice imitatively following either the flute or glass harmonica. ${ }^{70}$ Romana Margherita Pugliese explains that Nelly Melba's teacher, Mathilde Marchesi, had written the cadenza for her pupil, which was accompanied by the virtuosic flautist Jean-Louis Tolou. Donizetti originally wrote out a harmonic guide for the cadenza, probably aware that his first Lucia, Fanny Tacchinardi-Persiani, was capable of improvising her own. ${ }^{71}$ As the flute part would have to be organized first, she would have performed the cadenza with no accompaniment. ${ }^{72}$ For all that, Hadlock's

\footnotetext{
${ }^{68}$ Hadlock, 'Sonorous Bodies: Women and the Glass Harmonica', p. 509.

${ }^{69}$ Ibid, p. 519.

${ }^{70}$ Including in the 2009 Metropolitan Opera and Royal Opera House productions.

${ }^{71}$ Ashbrook, Donizetti and his Operas, p. 376.

${ }^{72}$ Romana Margherita Pugliese, 'The Origins of Lucia di Lammermoor's Cadenza', Cambridge opera Journal, Vol. 16, No. 1, 2004, pp. 23-42. William Ashbrook and Mary Ann Smart had earlier suggested the cadenza might be attributed to Teresa Brambilla, who performed the role in the $1850 \mathrm{~s}$, which still discounts any instrumental accompaniment of the cadenza in at least the first fifteen years. See
} 
indication of how the glass harmonica relates to Lucia's voice, characterisation and sound world (which is not the same as her audience's) is compelling. Her interpretation points to the flute's less allusive baggage. The glass harmonica conveys 'anxieties about young women's vulnerability to nervous derangement, taboo eroticism, and alienation from healthy, normal society...trance, other-worldly sounds, and feminine vulnerability'. ${ }^{73}$ The instrument's associations are then laid onto Lucia herself. However, the mimetic duet with the flute conserves the connection the flute has had with Lucia throughout the opera. Consequently, the link between wind instruments and disturbed mental states is strengthened - a connection that will appear in other mad scenes Donizetti composed.

What the glass harmonica's alleged similitude with the female voice insinuates about Lucia's voice itself is intriguing. Attention has been drawn to the separation of mood between Lucia's text and music often enough, and this disjunction connects with the Scottish-Gothic setting in an interesting way. Lucia serves as a lens through which to view the Scottish setting as Gothic - the irrational heroine at the centre of the Gothic scenario by proxy extends her thematic influence to the setting around her - as Lucia has embodied and created the dark Gothicism of Scotland. If the Scottish style is equated thematically through her outpouring of love, rather than any couleur locale, then it exists to intensify the dark tone. Much like the cheerful Scottish style acts to situate the Gothic in Scotland, any cheerfulness is only a veneer, through which the shadows underneath are visible. For the audience, seeing the Scottish dance choruses in relation to other events in the opera taints them, just as Lucia's joyful exclamations of love for Edgardo in the cabaletta of her cavatina resound with influences from her cantabile. Thus the glass harmonica seems the ideal instrument to represent the shades 
of the Gothic itself, particularly with its strong connections with voice and femininity.

Donizetti presumably chose to replace the obbligato line with the flute over other instruments because of its similarity in timbre with the upper register of the harmonica.

Example 2.13: The transition between the scena and the cantabile of the mad scene, Donizetti's Lucia di Lammermoor, bb. 78-94.
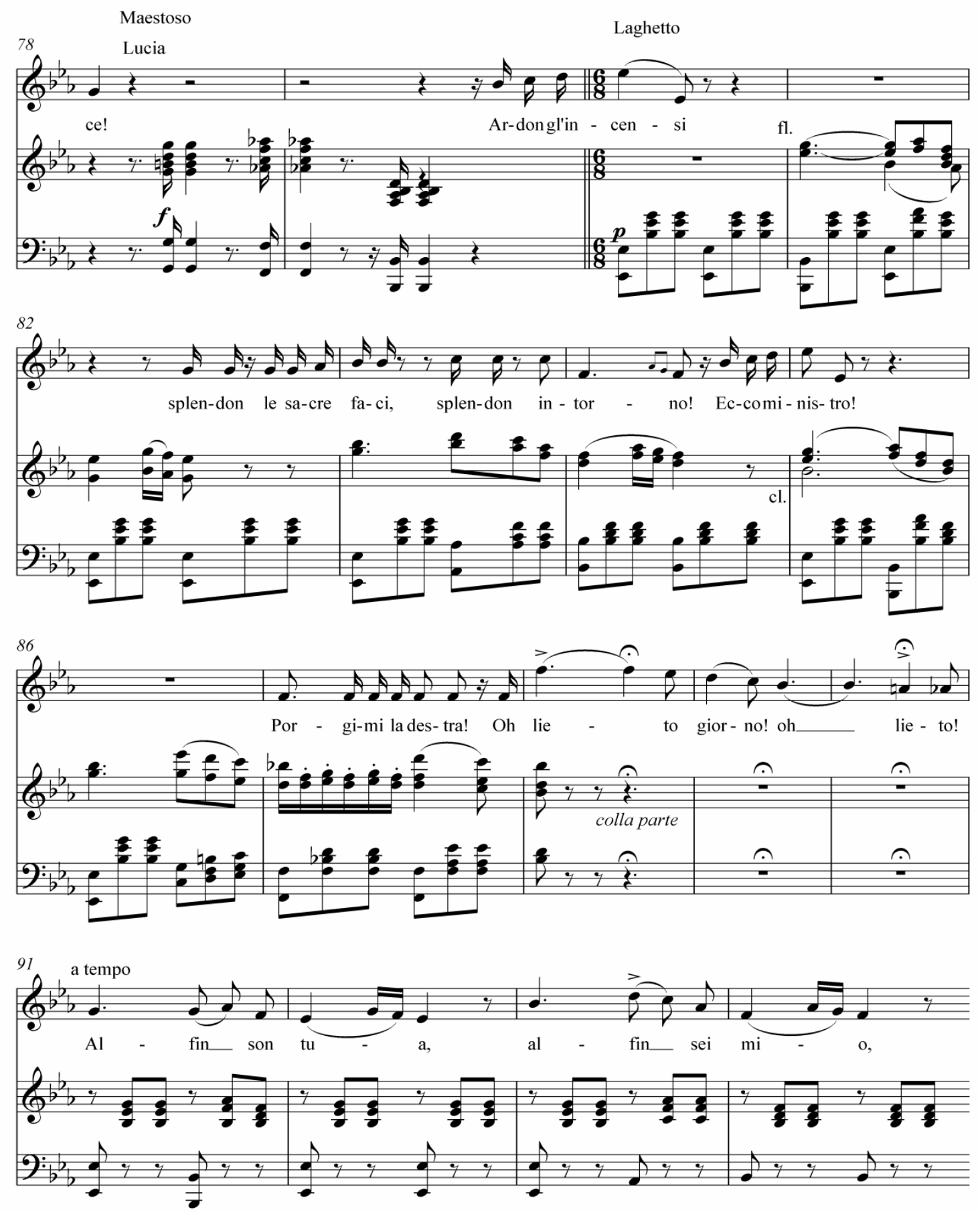
Although many of the Gothic associations are lost with the flute, it is the manner in which the instrument is used that is fundamental to depicting Lucia and the Gothic. ${ }^{74}$

Mary Ann Smart has detailed the ways in which Lucia's mad scene departs from conventional lyric form as one of the confines of Lucia's existence. Lucia's coloratura becomes excessive at the end of the slow movement of her mad scene, no longer restricted to the ends of phrases or passages of the text; she is given freedom through her vocality. ${ }^{75}$ Importantly, she explains that Lucia is so caught up in her own world that she fails to recognise a clear signal of her double aria form, and is thus free from structural constraints. She is oblivious to the shift from scena to cantabile; her own voice enters twelve bars after the orchestra announces the change through modulation, tempo change and the melody appearing in the flute (example 2.13). ${ }^{76}$ As Smart notes though, the rest of the mad scene adheres to conventional form somewhat surprisingly given the tension between static and active narratives in Lucia's cavatina. ${ }^{77}$ The intrusion of the ghost has an uncanny effect on the form of her earlier cantabile. However, what is most fascinating in musical symbols of the Gothic are Lucia's voice and the nature of her relationship with the orchestra to uncover the uncanniness of the scene. In this respect, the question of 'who hears what?' is revisited in Lucia's final moments.

Lucia's first line 'il dolce suono mi colpì di sua voce' ['the sweet sound of his voice affected me'] implies she hears the flute (or glass harmonica) as Edgardo, whom her thoughts focus on. Although as Lucia moves further into her mad scene, the flute does not appear to envoice a particular sound or voice. As Lucia literally hears

\footnotetext{
${ }^{74}$ Philip Gossett explains that from looking at the autographed manuscript of Lucia, the glass harmonica part was composed in detail, including instructions for articulation and ornamentation, which presumably were transferred to the flute part. See Divas and Scholars, pp. 434-5.

${ }^{75}$ Smart, 'The Silencing of Lucia', p. 128.

${ }^{76}$ Ibid, p. 131.

${ }^{77}$ Ibid, p. 133.
} 
Edgardo's voice internally, it is thus a surfacing of her noumenal voice. When Lucia appears, her scena is disjointed, she flits between declamation and melodic phrases, and she is out of sync with her accompaniment, especially the solo flute line which conveys the fractured state of her mind. The first time Lucia and the flute unite is on the repeat of her phrase 'ti son resa' ['I am yours again'], but the strings are still in antagonism with the melody, and to some degree with each other, as each part plays either triplets, off-beats, tremolos or on only the initial (strong) beat of the bar (example 2.14). As Lucia sings of her trembling, the strings and flute provide a musical illustration. Their sound connects Lucia's own physicality with the orchestral voice and portrays the way in which the flute simultaneously remains part of the orchestra sonority she is unaware of, as well as signifying a noumenal voice.

Example 2.14: The strings are rhythmically conflicting as Lucia's and the flute line unite, scena of mad scene, Act 3, Lucia di Lammermoor, Donizetti, bb. 21-4.

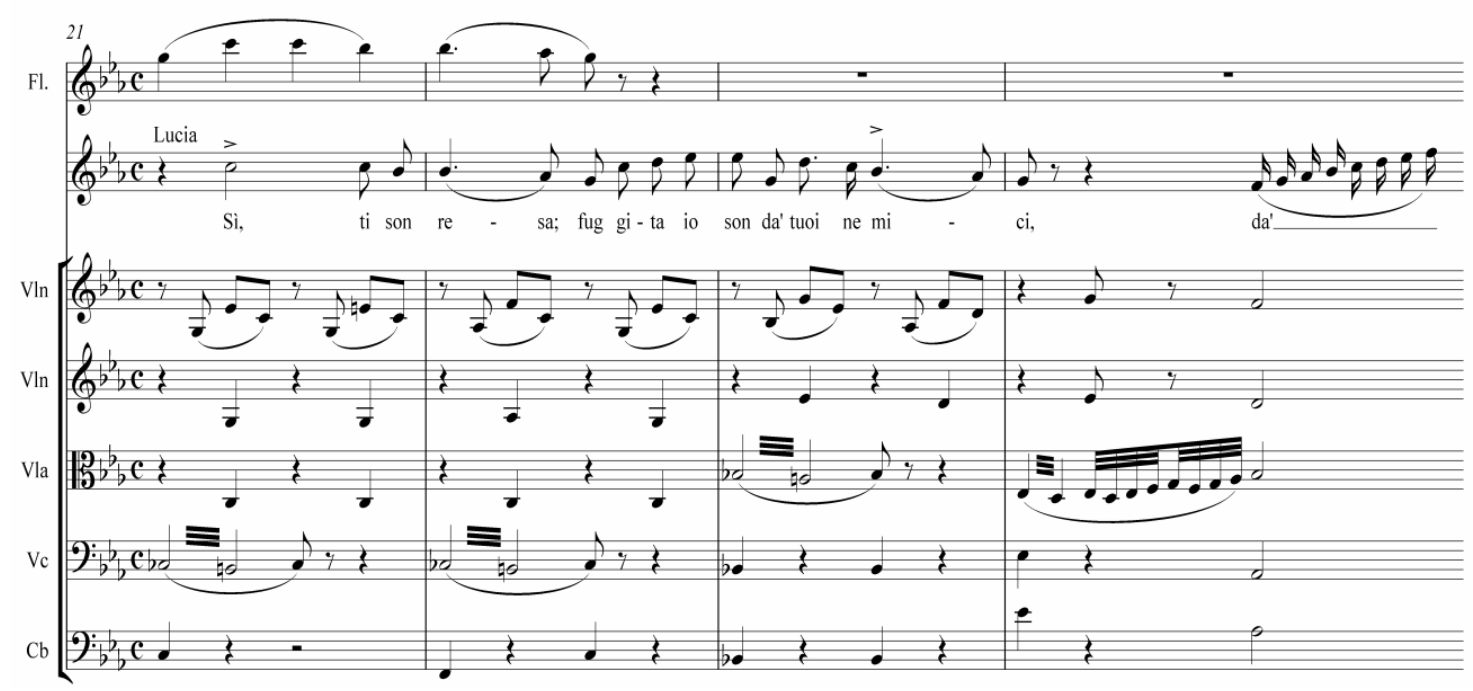

As the mad scene begins and Lucia recalls her wait for Edgardo by the fountain, the flute line retains the melodic shape of 'Regnava nel silenzio'. This musical return 
conveys the way in which the earlier intrusion of the ghost has eroded her sanity.

Although the audience hears what Lucia hears - the now-hazy noumenal voices of her imagination, as in the cavatina - they do not share in her visions. As Lucia re-recalls her ghostly encounter, the flute (her noumenal voice), once again merges with the orchestra. Donizetti paints the ghost for the audience using block chords, discordant intervals and accents, but Lucia is not conscious of her musical environment, drawn away by her vision.

The flute returns at the larghetto of her scena, but it is not the voice of Edgardo. After a solo flute phrase, Lucia asks 'Un'armonia celeste, di non ascolti?' [Celestial harmonies, did you not hear them?] It is a moment where Lucia almost gains lucidity, as she is not only now musically conscious, but also aware of her (onstage) audience. However, her words deny her any return from madness because they show that in her delusion she has misheard the flute phrase as her wedding hymn, rather than the motive which appears in the celli when she signs the marriage contract. ${ }^{78}$ The tune of her 'wedding' with Edgardo is the only quotation unaltered in the mad scene, the flute again acting as a noumenal envoicing of Lucia's internal music (at 'Ardon gl'incensi') (example 2.15).

Example 2.15: The return of the wedding music ('Verranno a te') in the mad scene, Donizetti's Lucia di Lammermoor, bb. 42-50.
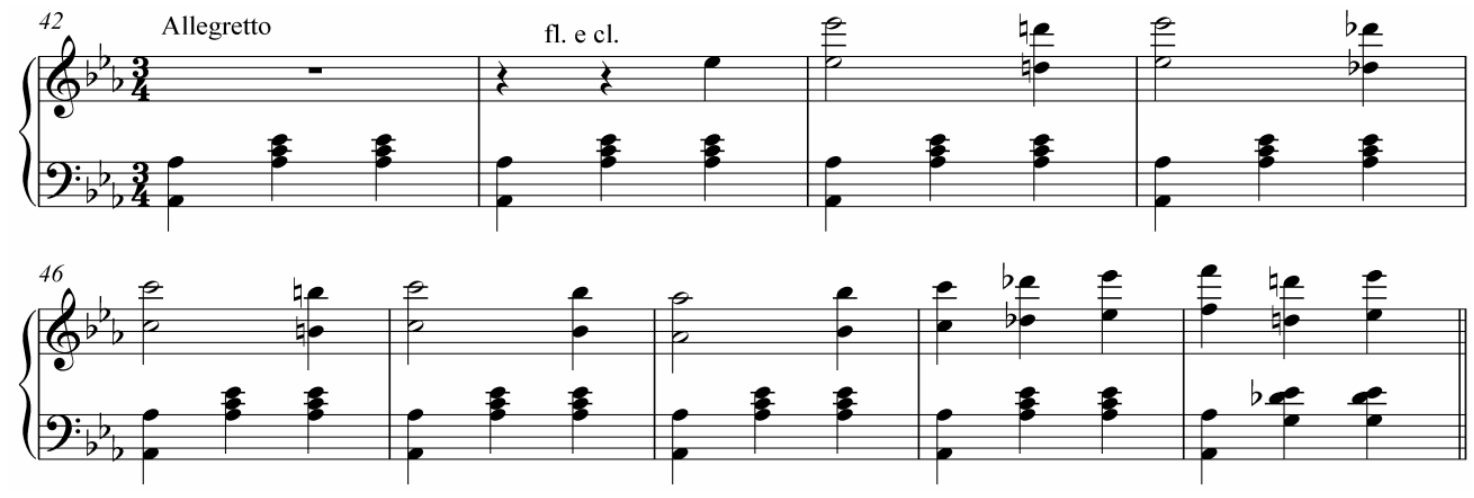

${ }^{78}$ Ashbrook, Donizetti and his Operas, p. 379. 
It is perhaps this sustained pull between Lucia's senses - vision and hearing - and an associated shift between musical consciousness which evokes the Gothic tone and her broken mind most effectively. For in the scena and cantabile her accompaniment is tied to her text, changing the mood as her flashes of the past move between horror and happiness - her joy is within the context of her imagined wedding to Edgardo. Like Anna's jolt back to reason by the entrance of the guards, Lucia too surfaces from her internal world briefly to, in a flash of self-awareness, express her misery ( $\mathrm{Ah}$ ! Me misera') and remind Enrico that she is his victim.

There are also musical parallels with the march in Anna Bolena announcing Enrico's entrance. In Lucia's cabaletta, 'Spargi d'amaro pianto', however, there is an uncanny separation between the moods of text and voice as in the Act 2 finale (example 2.16). Huge ascending leaps and descending chromatic notes evoke the 'gibbering' and 'frantic gestures' of Scott's Lucy musically. Significantly though, the music does not emulate the physical sounds of Gothic terror. Even though Lucia sings of sobbing, and syllables of 'pianto' are over a semitone between C and B flat, it is not enough to use only a semitone 'lament' to symbolise her corporeality. In spite of the text and music seeming to convey utterly contrasting moods, the text does appear to impact the musical setting in its refrain from materiality. Lucia sings in a cheerful E flat major:

Spargi d'amaro pianto Il mio terrestre velo, Mentre lassù nel cielo Io pregherò per te.

Al giunger tuo soltanto

Fia bello il ciel per me!

[Scatter bitter tears over my earthly remains, While above in heaven I will pray for you. Only when you arrive Will heaven be beautiful to me!] 
Example 2.16: 'Spargi d'amaro pianto', Act 3, Lucia di Lammermoor, Donizetti, bb. 270-95.
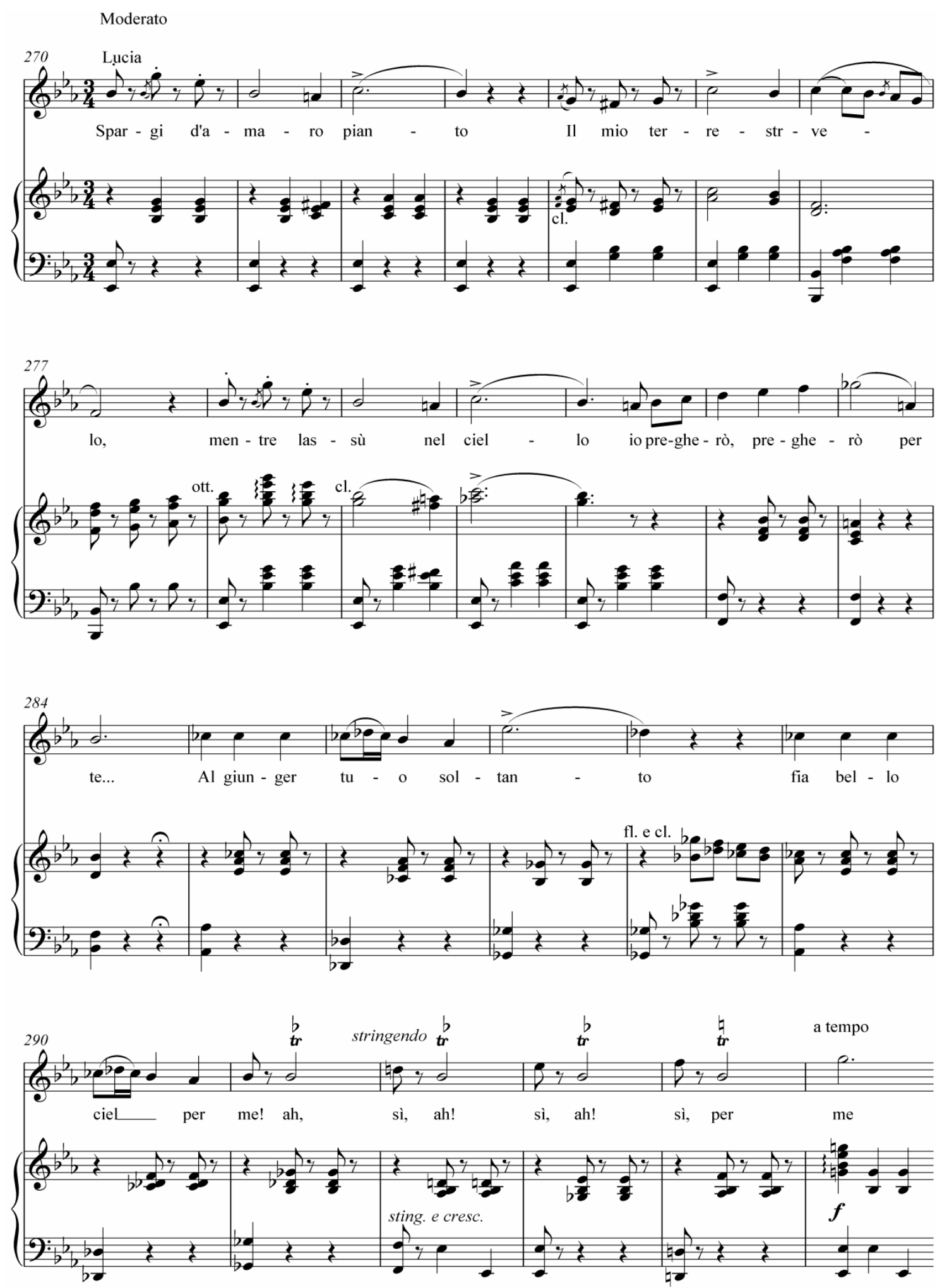
The last words of Lucia convey the tension between the physical and the otherworldly that underpin musical representations of the Gothic. In the final scene, the chorus enters bearing the news that Lucia is dying, and Edgardo's laments are met by knells affirming Lucia's death. Her offstage death in fact appears to highlight her connection with the other-worldly as the audience cannot see her materiality, and her own voice is silenced by death. Lucia is resolutely envoiced from another realm, as a disembodied phenomenal sound lingering in the consciousness of the opera's other characters and the audience.

Lucia carries all the marks of a Gothic 'heroine': she hallucinates, visualising a ghost at the fountain, a crumbling Gothic remnant of the past itself. She furthermore displays a mental fragility, impressionable to superstitions and is imprisoned by patriarchal society and cornered by her sense of familial duty. After breaking under this pressure, she swoons, in true Gothic-romance and operatic style, and finally, Lucia stabs her husband in an hysterical state and dies. All these aspects relate to plot, and are evident through reading the libretto alone. This is, of course, an essential part of the opera. However, in Lucia the Gothic suffuses the opera's music. It is revealed in subtle, yet penetrating ways through Lucia herself, where sound is conceived from, and is representative of, her vision in a type of synesthetic junction. The operatic Gothic emerges from intriguing relationships between the material and metaphysical realms of Lucia - her body and singing voice performing on stage, and her mind. The ways in which the sound world shifts, representing the convergence and disconnection of perceived and unperceived audible-visual realms, creates an unsettling effect for the audience (and the characters on stage). In Lucia, Donizetti's score incites a deeper sense of the horror, terror and excitement of the Gothic for the audience than the librettist Cammarano's (Scott-inspired) scenario alone. Therefore Lucia di 
Lammermoor is a Gothic opera in both the portrayal of the heroine amongst the turmoil of her internal and external worlds and for the feelings the Gothic induces for the audience. 


\title{
Chapter Three: The Witches' Lair
}

\author{
Verdi's Gothic Opera
}

The focus of this study has so far revolved around a Donizettian nexus of Gothic, or at least 'Gothic flavoured', operas composed within the same decade, yet there are a number of reasons for making a twelve year leap from Lucia in 1835 to la prima of Verdi's tenth opera, Macbeth. At its premiere, Macbeth's Gothicism was conveyed through its setting, notwithstanding the substantial attributes of the Gothic presented as the opera progresses: witches, prophecies, darkness, murder, betrayal, visions, a ghost, apparitions, patriarchal succession, madness and a tragic ending. Macbeth further solidifies how necessarily connected the visual representation of the Gothic is to the occurrences in the plot (figures 3.1 and 3.2). However, a demonstration of how a work is 'Gothic' cannot be restricted to its setting alone. Indeed, in his preface to Cromwell, Hugo indicates that the local colour must arise from deep within a work, rather than being overlaid superficially. ${ }^{1}$

\footnotetext{
1 'Non qu'il lui convienne de faire, comme on dit aujourd'hui, de la couleur locale, c'est-à-dire d'ajouter après coup quelques touches arides ça et là sur un ensemble du reste parfaitment faux et conventional. Ce n'est point à la surface du drame que doit être la couleur locale, mais au fond, dans le couer même de l'oeuvre, d'où elle se répand au dehors, d'elle- meme, naturellement, également, et, pour ainsi parler, dans tous les coins du drame, comme la séve qui monte de la racine à la dernière feuille de l'arbre. Le drame doit être radicalemente imprégné de cette couleur des temps, elle doit en quelque sorte y être dans l'air, de façon qu'on ne s'aperçoive qu'en y entrant et qu'en en sortant qu'on a changé de siècle et d'atmosphère.' ['Not that it is advisable to make as is said today, local colour, that is, to add as an afterthought a few discordant touches here and there to a work that is conventional and false. The local colour should not be on the surface of the drama, but within it, in the very heart of the work, whence it spreads of itself, naturally, evenly, and, so to speak, into every corner of the drama, as the sap ascends from the root to the tree's topmost leaf. The drama should be thoroughly impregnated with this colour of the time, which should be, in some sort, in the air, so that one detects it only on entering the theatre, and
} 


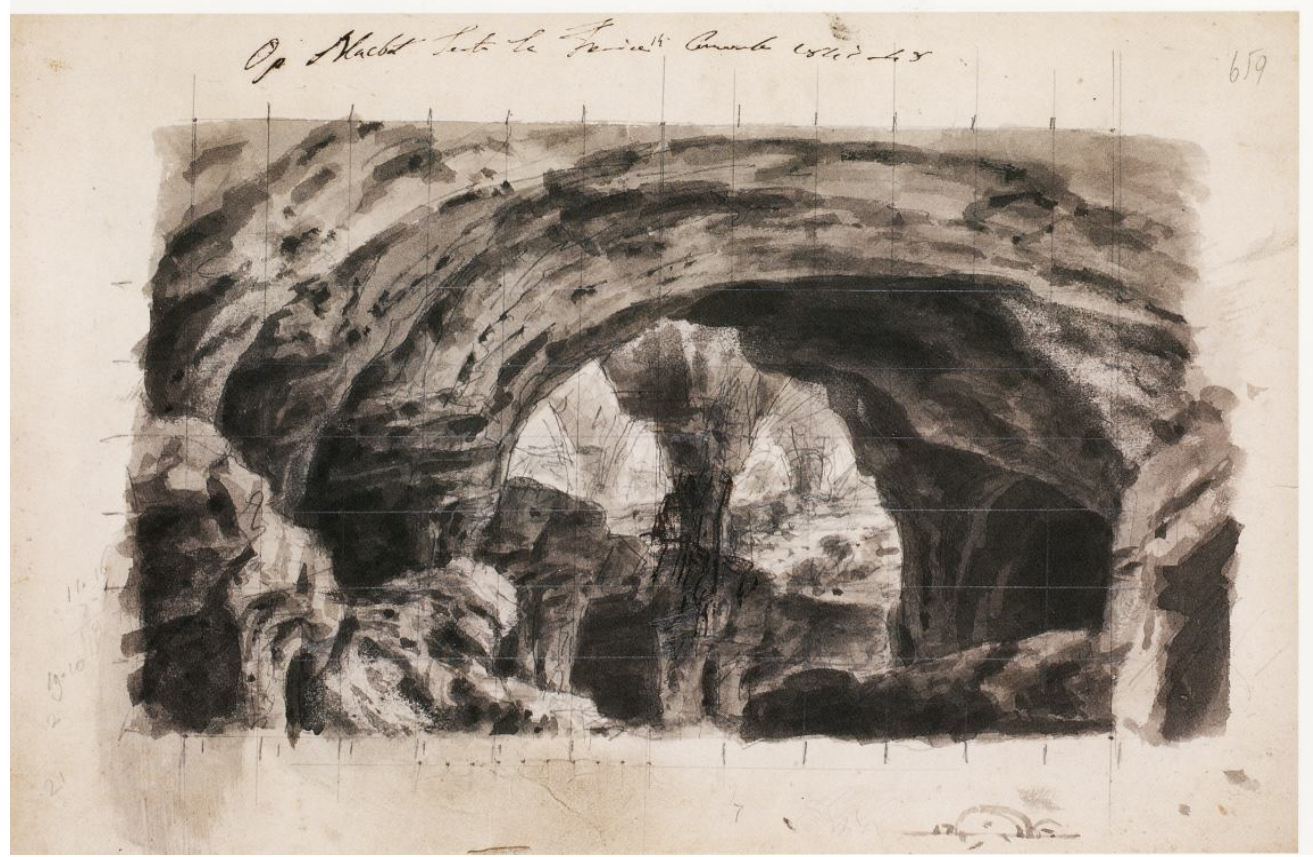

Figure 3.1: Giuseppe Bertoja's stage design for the witches' grotto in Act 1, scene 1 of Verdi's Macbeth (Venice, Teatro La Fenice, 1847).

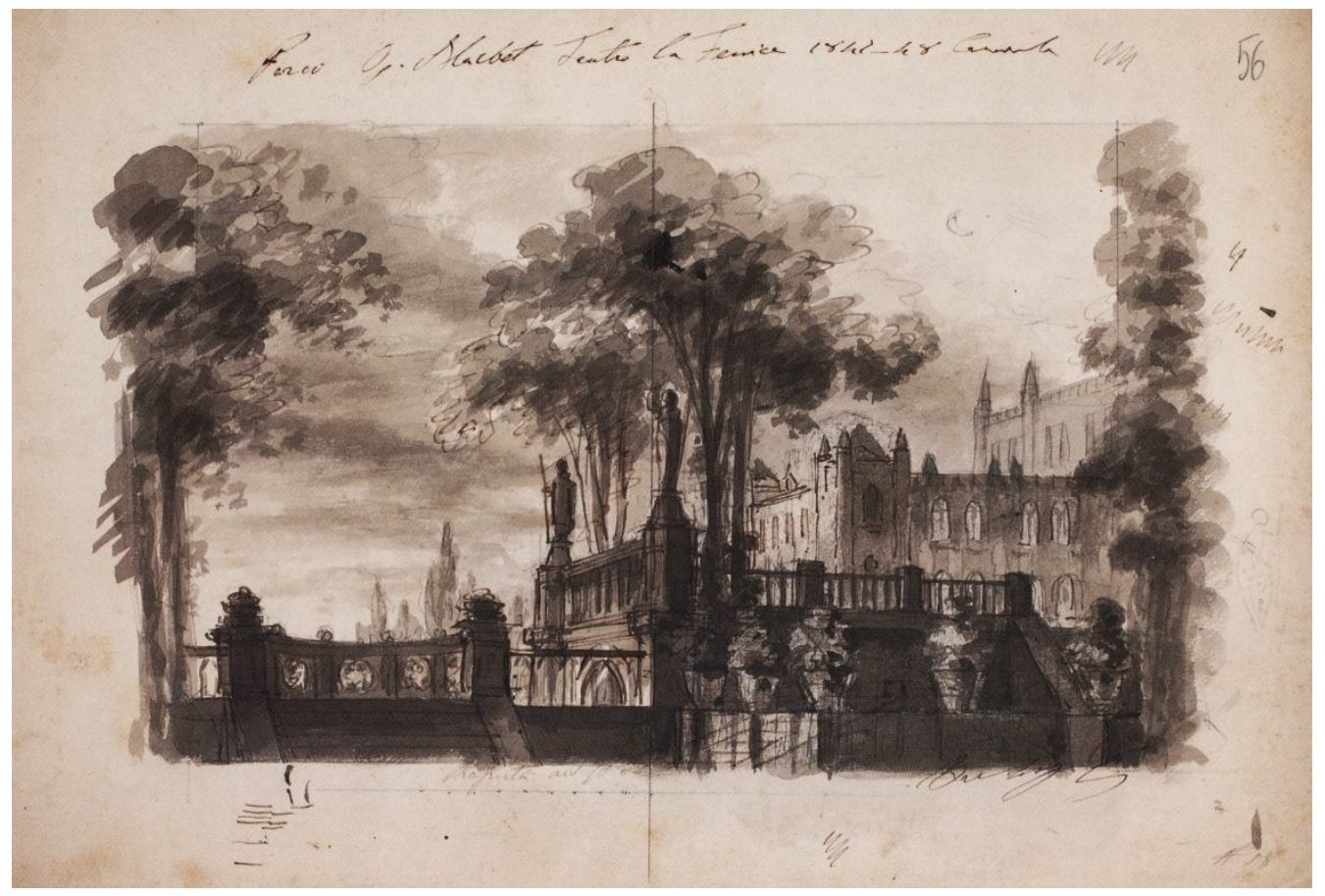

Figure 3.2: 'Parco. In lontananza il castello di Macbeth', Giuseppe Bertoja's stage design for Act 2, scene 2 of Verdi's Macbeth (Venice, Teatro La Fenice, 1847).

that on going forth one finds one's self in a different period and atmosphere.'] See Victor Hugo, 'Preface' to Cromwell, in Théatre: Les trois premiers actes de Cromwell, Hetzel: Paris, 1858, p. 33. 
In Macbeth, like in Lucia, the responses of the characters to Gothic situations convey the irrationality and harshness of the Scottish setting. Verdi's insinuations of Scotland itself are not visible in the set design; they rely solely on the references to the country in the libretto and the costuming. Yet the Gothic setting in Scotland remains a fundamental element of the opera. While researching the historical figure of Macbeth, Verdi wrote to academics and historians in Edinburgh and London and then arranged for the costumes and set to be constructed there and was thus aware of constructing an 'accurate' representation of Scotland. However, many of his ideas for staging the opera came from investigating productions of Shakespeare's Macbeth in England, where 'the play ha[d] been performed continuously for two hundred years'. ${ }^{2}$ Thus the English sets Verdi used as his models may not have been explicitly 'Scottish' themselves.

The tartan costuming in Macbeth is also reminiscent of Donizetti's Scottish opera. At the premiere, Scottish dress was seen on the men, who wore plain and tartan kilts. The tartan is not ubiquitous, though, as the plaids worn by the men over their shoulder appear to also be plain or striped as well as tartan (figure 3.3). It is possible the women's chorus wore tartan in the final Act, where they take on the roles of dispossessed Scottish people, but there are no costume sketches for this part of the opera. The only hint of tartan among the women's costumes is perhaps the trim on Lady Macbeth's maid dress. The maid is seen standing behind Lady Macbeth in the mad scene, where Lady Macbeth herself is clothed in a conventional white gown (figure 3.4).

\footnotetext{
${ }^{2}$ David Rosen and Andrew Porter, Verdi's 'Macbeth': A Sourcebook, Cambridge: Cambridge University Press, 1984, p. 27. (This text will be abbreviated as Sourcebook in subsequent references to avoid confusion with the opera.) All material from the Sourcebook quotes the English translations published therein, without the Italian originals (as the book is widely available). However, references to the Macbeth libretto are given in the original language, with my translations contained in parentheses.
} 


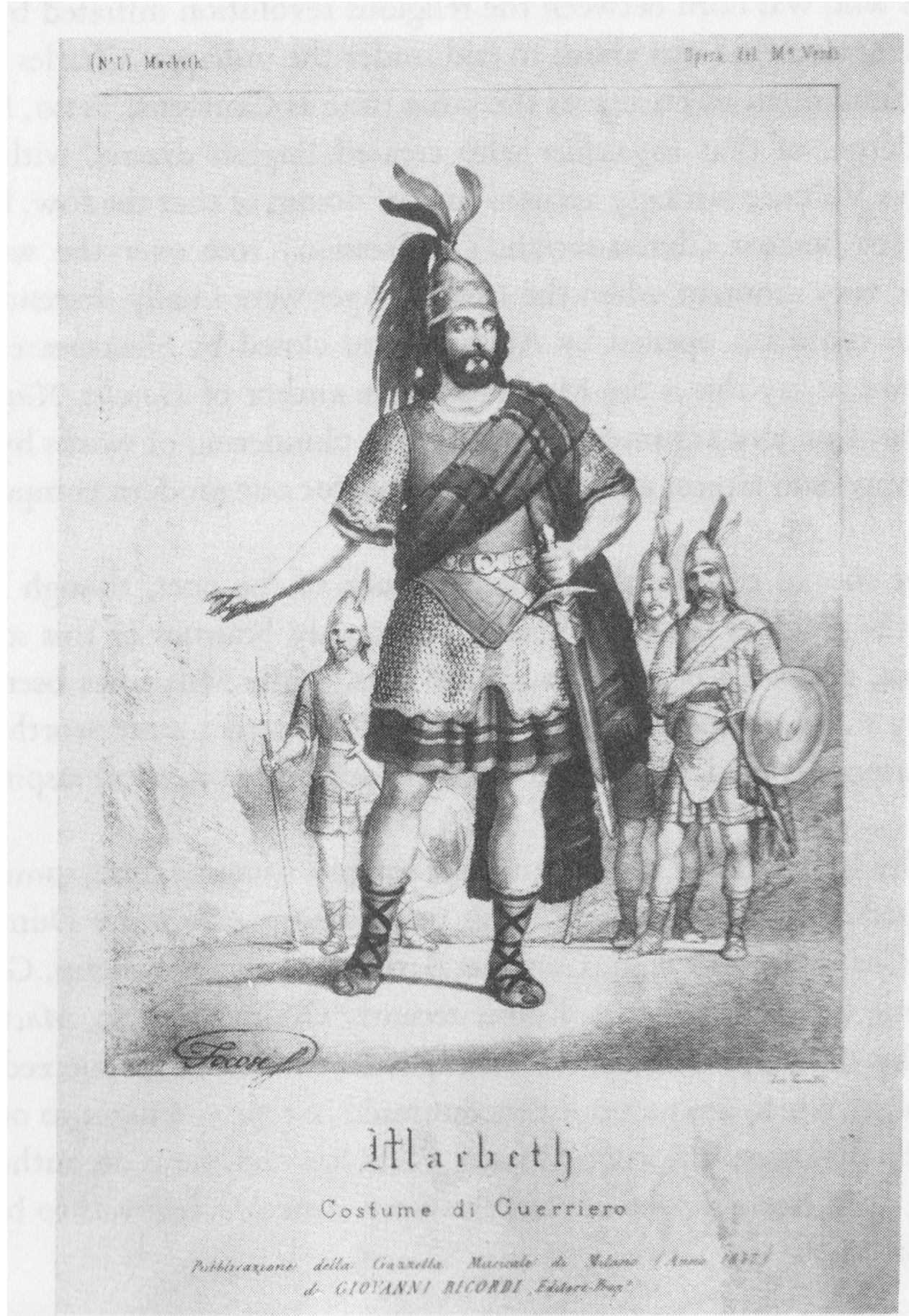

Figure 3.3: Costume for Macbeth in Verdi's Macbeth (Venice, la Fenice, 1847). 


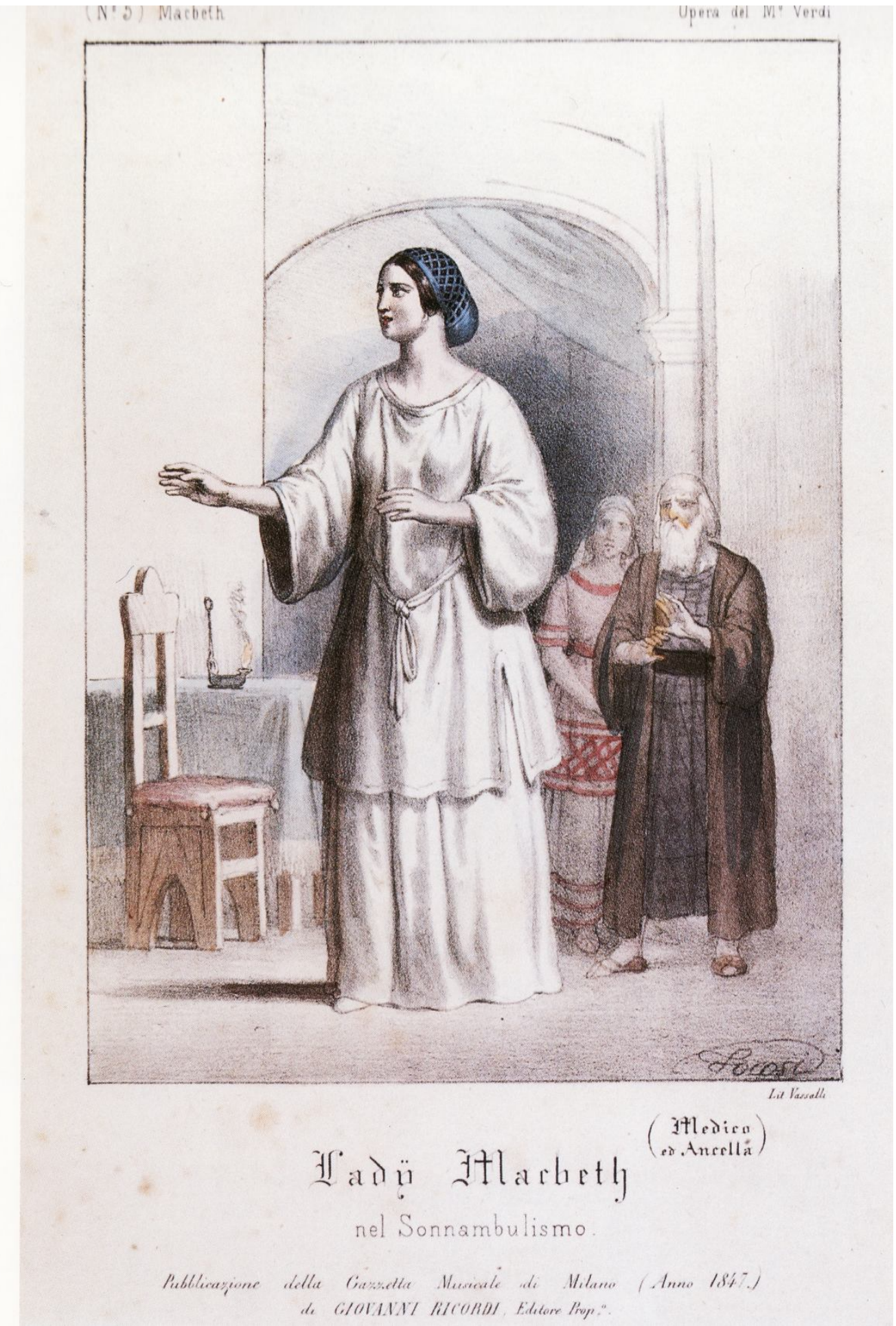

Figure 3.4: Costume for Lady Macbeth in Act 4 of Verdi's Macbeth (Venice, la Fenice, 1847). 
In earlier scenes, the dress Lady Macbeth wears has an outer layer that resembles chain mail, and consequently, more emphasis is visually placed on her shift from murderer to madwoman.

Verdi aimed to convey all the drama of Shakespeare's play. Macbeth is often touted as a turning point in Verdi's career and an essential part of Verdi's dramaturgy is his conscious decision not to use the compositional techniques that Donizetti and Bellini relied on to signify dramatic and emotional tension, and especially female madness. Yet Donizetti's operas Anna Bolena, Lucrezia Borgia and Lucia di Lammermoor were all noted for their dramatic power and Verdi was still working within the conventions of Italian opera. As a result, the way in which the Gothic is evoked musically in Macbeth shows some similitude with Lucia di Lammermoor despite the way in which Verdi adapts typical forms to suit the needs of his drama.

The tension between the characters' psyches and their external, physical realms are retained, but the imaginings of the subconscious are presented in a sharpened musical form. Rather than relying so much on instrumentation, especially the uncanny relationship between Lucia and the flute, Verdi's musical emblems of the Gothic are most clearly articulated through motivic movement and recurrence, and despite Hudson and Esse's claims that this echoes a German analytical process and is not an approach completely at ease in Italian opera. The transcendence of sound between operatic voices sheds light on the physical symbols of the Gothic that cause the reactions of horror and terror - blood, knives and bodies - on which the Macbeths' thoughts focus.

We have seen Donizetti's methods for madness, his deviations from Italian operatic conventions at crucial dramatic and Gothic episodes, and the relationship he builds between his soprano and the orchestra. All these musical techniques provide a 
model for Verdi's Macbeth. However, the conflicting empowerment and derangement the heroine gains from her voice as it retells snippets of musical memory in a climactic display of vocality does not ensue in Macbeth. Lady Macbeth's sonnambulismo is devoid of the typical structure and lyric prototype of early nineteenth-century Italian opera. Her musical demise departs radically from Donizetti's prima donnas, who convey their delusions by resisting conventional forms only briefly, as seen, for example, in Lucia's failure to recognise the change outlined by the music from the scena to the cantabile. Lady Macbeth's mad scene has no aria. Instead, Verdi closely follows Shakespeare's play in a move most unlike Donizetti's adaptation of Scott in Lucia (although Verdi extended or omitted - 'operatised' - other sections of Shakespeare's Macbeth in a similar manner to Donizetti). There is less chance for Lady Macbeth to appear empowered in her mad scene as she performs to Verdi's express directions of 'voce cupa' ['in a hollow voice'] with minimal movements: her imminent death is made apparent through her vocal disintegration. ${ }^{3}$

On a perfunctory level, revisiting Verdi's opera directly after Donizetti may seem to make light of Donizetti's contribution to Romanticism and his ushering of the Gothic onto the operatic stage. This is by no means the case though, for as Marshall Brown claims, 'the significance of an imaginative creation lies always ahead of it, not in some intrinsic perfection'. ${ }^{4}$ In this way we see Donizetti as forward-looking, his Gothic Lucia as an operatic (and dramatic) precedent for Macbeth and Verdi's treatment of internal and external realms of the mind and the stage. Additionally, Verdi's Macbeth shows, at least initially, the continuing popularity of Gothic themes for opera in Italy and the ways in which the subjects were developed dramatically in the face of evolving operatic techniques and audience expectations. Verdi's operatic dramatisation of

\footnotetext{
${ }^{3}$ Letter of 11 March 1865 Sourcebook, p. 110.

${ }^{4}$ Marshall Brown, The Gothic Text, Stanford: Stanford University Press, 2005, p. xix.
} 
Shakespeare reveals a new side to the Gothic, one that attempts a more realistic psychological depth. ${ }^{5}$ After Macbeth, operas with a Scottish setting dwindled as the Gothic was driven by the representation of the human, rather than the supernatural. Criminality, betrayal and deception become more prominent tropes than ghosts or visions as the horror and terror of the grotesque and other-worldly give way to the horror and terror of human capability. Macbeth conveys more explicitly than Lucia both a supernatural and a human side to the Gothic.

Macbeth was positively received in 1847 when it opened at the Teatro della Pergola in Florence for the Lenten season, and it received further productions in other cities. However, its revival in 1865 for Paris did not meet expectations and the work discontinued after fourteen performances. ${ }^{6}$ The vogue for Gothic opera then, appears to have been prefigured by tragic subjects in the 1810s, with works such as Rossini's $L a$ Donna del Lago, and then embraced by Donizetti in his works of the 1820 s that were based on even more grotesque scenarios than many of his operas from the 1830s. As for Verdi, it is obvious he found less inspiration in English and Scottish history than his predecessor (outside of setting Shakespearean texts) and there are fewer of his works that can be associated directly with the Gothic. This change in inspiration in part reflects his time. The vogue for Scott peaked in the 1820s and 1830s, and although Scott continued to be popular, the Gothic aspects may have seemed less novel thereafter. The growing numbers of continental Europeans travelling to Scotland may

\footnotetext{
${ }^{5}$ Shakespeare is believed to have written Macbeth in 1606, but the printed copy in the first folio shows this may have been a revision. See William Shakespeare, Macbeth, in The Oxford Shakespeare: The Complete Works (2ed.), Gary Taylor and Stanley Wells (eds.), Oxford: Oxford University Press, 2005, p. 969.

${ }^{6}$ The Paris adaptation of Macbeth is the most often performed version today, despite the Italian version receiving more productions in the nineteenth century. While it is common practice today for the third Act ballet to be cut, the other changes Verdi made are mostly retained, including substantial changes to the most dramatic scenes of the work - the Act 1 duet between the Macbeths and Lady Macbeth's sonnambulismo. One of the work's famous arias, Lady Macbeth's 'La luce langue', is also a later addition, along with Macbeth's aria in the final Act.
} 
also have begun to erode the country's exotic status. Shakespeare, on the other hand, was seen as a theatrical master by the Romantics; his combination of comedy and tragedy and the extreme states of emotion struck a chord not only with Verdi, who set a number of Shakespearean texts to music, but with composers writing all over Europe in many different genres of music. ${ }^{7}$ In Verdi's output, Macbeth is one of the most obviously Gothic works, however other operas do border on the Gothic. I masnadieri, written in the same year as Macbeth and based on Schiller's Die Räuber is perhaps the only other example of an outright Gothic opera. I masnadieri comprises a Gothic setting, including a castle, wood and graveyard in Germany and a scenario involving familial betrayal and deception, imprisonment in a tower, impending execution, and a violent stabbing. In both operas, but especially Macbeth, there is a more pronounced emphasis on psychological intensity than is encountered in Donizetti's Gothic operas. To some extent, the increasingly important emphasis on realistic psychological portrayals alludes to a Gothic equivalent of the two identifiable Scottish styles. One is a dark Gothic mood of psychological trickery and the misery it causes, and the other a version that presents a less serious (or perhaps less believable) series of events emphasising the 'shock value' and entertaining pleasure of gruesome scenarios. There is evidence of both of these aspects in Macbeth - even occurring at the same time in the Act 2 duet as the Macbeths perform covered in King Duncan's blood. Yet there is increasing interest in the Gothic as a psychological condition, with the stage spectacle, although vital, becoming secondary to intensely dramatic characterisation.

The major problem in any musical study of Macbeth is the disjunction of musical styles between Verdi's original 1847 opera and his substantially reworked 1865

\footnotetext{
${ }^{7}$ Shakespeare holds the accolade of being the writer most set to music. See Roger Fiske and George Biddlecombe, 'Scott, Sir Walter', in Grove Music Online, Oxford Music Online, http://www.oxfordmusiconline.com/subscriber/article/grove/music/25256, (26 May, 2009).
} 
version for Paris. As a result of his revisions, much of Verdi's score shows the impact of his so-called 'galley years' in honing his operatic skills and is more closely aligned with the style of his later works. While the original version is closest in era to the other operas used as examples of the Gothic in this study, Verdi himself considered the 1865 score as definitive. ${ }^{8}$ This creates the problem of a twenty-nine year interlude between Lucia and the second Macbeth: these were twenty-nine of the most politicised years in Italian history, and twenty-nine years for substantial change to occur in opera, both in Italy, and throughout Europe. ${ }^{9}$ Nonetheless, this aperture can work in favour of a study of the Gothic. It opens passages for further exploration, including the Gothic's inability to thrive on the opera stage despite the longevity and continuous popularity of the genre in literature. Thus considering Macbeth gives a wider perspective of shifting musical representations of the Gothic.

\section{Grand Opera and Gothic Opera}

Between the 1850s and 1870s the opera scene in Italy had, as David Kimball articulates, 'never been so completely dominated by a single individual as it was by Verdi', whose contemporaries remain largely unknown today. ${ }^{10}$ The period in Italy was marked significantly by the conclusion of the Risorgimento, when in 1861 Italy's various states and provinces (excluding Rome and Venice) were unified. The high taxes forced on Italians in order to repay the country's debts and the persisting differences in the new Italian state between 'the progressive and the backward, the prosperous and the poverty

\footnotetext{
${ }^{8}$ Giuseppe Verdi, Macbeth: The Works of Giuseppe Verdi, I:10, edited by David Lawton, Chicago: Chicago University Press, 2003, p. xi.

${ }^{9}$ Verdi had been approached about staging Macbeth in Paris in 1852, but it never eventuated. See Budden, The Operas of Verdi: From Oberto to Rigoletto, Oxford: Oxford University Press, 1991, p. 275.

${ }^{10}$ David Kimbell, Italian Opera, Cambridge: Cambridge University Press, 1991, p. 564.
} 
stricken, the democratic republican and the quasi-feudal' meant many in favour of the unification were disillusioned when its ideals did not eventuate. ${ }^{11}$ Opera houses suffered, no longer financially buoyed by their states, and the commissioning of new operas slumped as theatres instead chose to reproduce, as in other European countries, old operas by a smaller number of composers, effectively initiating the operatic canon. These operas were predominantly of Italian origin - by Rossini, Bellini and Donizetti but beginning in the 1840s, foreign, works - mainly from France - made their way into the repertory.

Meyerbeer, the composer whose grand opera L'Africaine displaced the Paris Macbeth, gained popularity in Italy after his Robert le diable was produced as Roberto il diavolo at La Pergola in 1840 also under the direction of Lanari. Meyerbeer's opera can most certainly be considered Gothic, and it was this opera in particular that 'became a symbol of cultural renewal in Italy, especially within artistic and intellectual circles', as Gloria Staffei explains. ${ }^{12}$ French grand opera was a likely motivator in Verdi's choice of a fantastic subject, to rival the increasing popularity of Meyerbeer's works and to challenge both the dramatics and the spectacle of Italian opera. Roberto il diavolo's influence on Macbeth can be largely imputed to the 'ballet of the nuns' in the third Act of Meyerbeer's work. ${ }^{13}$ Verdi wrote to Lanari in October 1846 telling him that he would 'need dancers for a graceful little ballet at the end of Act 3.' He added, surely hoping to emulate the success of Meyerbeer's ballet: 'Don't worry (I repeat) about expenses, because you'll be rewarded, I hope. ${ }^{, 14}$ Unfortunately, this scene was never to eventuate because of the premiere's timing. Lanari expressed his concern to Piave in

\footnotetext{
${ }^{11}$ Ibid, p. 536.

${ }^{12}$ Gloria Staffei, 'Grand Opéra in Preunified Italy: Metamorphoses of a Political Genre', The Opera Quarterly, Vol. 25, No. 3-4, Summer-Autumn 2009, p. 210.

${ }_{13}$ Gloria Staffieri, 'Da Robert le diable a Macbeth: Influssi di Meyerbeer sulla produzione verdiana degli anni Quaranta', Studi Verdiani 13, 1998, pp. 13 - 44.

${ }^{14}$ Letter of 15 October 1846; Rosen and Porter, Sourcebook, pp. 11-2.
} 
November 'that the aerial spirits which you say must dance, have to be taken out - as I wrote some time ago also to Verdi - because dancing of any kind is forbidden during Lent, and so they are inadmissible' ${ }^{15}$ All the same, Verdi was not easily deterred and seemed intent on positioning the dance as dramatic action in order to justify its inclusion, chastising Piave for once again failing to take a personal interest in Macbeth: ${ }^{16}$

What's all this trouble you're giving me about the aerial spirits who aren't supposed to dance? Do them as indicated. The poem and the music must be that way, and in that way they must be done. Note that while the aerial spirits are dancing around Macbeth in his faint, the witches have to say two stroffette etc. etc. ${ }^{17}$

The 'ballet of the nuns' in Roberto has a narrative function, and Verdi too, wanted his dances to add to the dramatic weight of the opera rather than being superficial entertainment. In effect, he wanted the fantastical spectacle inserted into the Gothic plot, blurring any divide between the two and thus adding to, rather than detracting from his dramatic ambitions. ${ }^{18}$ Lanari too encouraged Verdi towards the fantastic, having spent much time promoting Roberto il diavolo for Florence and wanting to capitalise on the popularity of the Gothic and fantastic scenarios. Furthermore, Lanari's appetite for transalpine imports saw him arrange Italian productions of Meyerbeer's Les Huguenots (as Gli Angelicani), and his influence within various theatres in Italy and Paris, paired with his exhaustive and meticulous knowledge of the theatre, meant his opinion on

\footnotetext{
${ }^{15}$ Letter of 23 November 1846; Ibid, p. 18. Italics Lanari's

${ }^{16}$ In the end Verdi was unhappy with final libretto from Piave. Budden explains the title page bore no name of a librettist, even though both Piave and Maffei were paid for their efforts: Piave in full (despite Verdi's obvious dissatisfaction with his final version), and Maffei with a gold watch; see Julian Budden, The Operas of Verdi pp. 271-2; Letters of 30 March and 11 April 1847; Ibid, p. 59.

${ }^{17}$ Letter of 10 December 1846; Ibid, p. 21.

${ }^{18}$ It is probable Verdi saw a production in Paris in the 1840 s, or any number of productions in Florence, Milan or even another Northern Italian theatre. See Gloria Staffei, 'Grand Opéra in Preunified Italy, p. 208.
} 
operatic subjects was worth heeding. ${ }^{19}$

Verdi and Lanari both must have initially believed a perfect chord had been struck with the 1847 Macbeth. It conveyed a sense of the increasingly popular French grand operatic models, but was still attuned to an Italian audience and their expectations that it would (mostly) adhere to Solita forma, although the exceptions to these formal conventions are striking. A setting with couleur locale (seen here in both the historic and Scottish setting), while traditionally useful in negotiating censorship in operas displaying an objectionable political or religious bent, was also a distinction of grand opera. Grand opera's impact is also visible in Macbeth's esteemed Shakespearean literary origin and the narrative's potential for spectacle and modern theatrics. With the success of Italian operatic performances from the 1840s onwards resting on the reputation of the composer, or on novelty and spectacle, Verdi's latest opera seemed destined for immediate distinction. For the majority of works in the mid to late nineteenth century, the emphasis on dramaturgy included an increasingly 'realistic' or 'true' adaptation in setting a literary text, even though this did not always lead to an opera's success. Verdi, as one of the proponents of a form of 'literariness', achieved what Boito in his Mefistofele some years later set out to do, but it is telling when making any comparison between the two works, that it was the elder composer's musical brilliance which held Macbeth together. Boito's opera, while the libretto is close to its origins in Goethe, lacks some musical consistency and comprehensibility, and as David Kimbell explains ‘it was Boito's power of musical invention, not his intelligence that failed him'. ${ }^{20}$

Shakespeare's Macbeth had not been performed on stage in Italy by the time

\footnotetext{
${ }^{19}$ Ibid, p. 210; John Rosselli, 'Opera Production 1780-1880' in Opera production and its resources, edited by Lorenzo Bianconi and Giorgio Pestelli, Chicago: University of Chicago Press, 1998, p. 119. ${ }^{20}$ David Kimbell, Italian Opera, p. 574.
} 
Verdi's opera was performed. It was not until he was in London for I masnadieri in 1848 that Verdi himself saw the play. While he aspired to stay as close to Shakespeare as possible, Verdi was working from multiple translations and some adaptations were inevitably made for the staging to better suit operatic purposes. Consequently, when Verdi tells his first Lady Macbeth, soprano Maria Barbieri-Nini, 'I wish the performers to serve the poet better than they serve the composer', he indicates Shakespeare (as opposed to the librettist), but to a certain extent the opera is effected by the various translations he consulted. ${ }^{21}$ Rusconi's translation was the first in prose (in 1832), after general lamentations, including by Madame de Staël, that Shakespeare's works were only available in defective poetic translations. It was widely believed in the nineteenth century that Rusconi had been faithful to the original play, and certainly in most issues of plot he was. Yet there still remains the issue of those Shakespearean characteristics double entendres and further word associations and inventions - that became lost in translation, often losing the sense of Shakespeare's potent imagery, but on the other hand making it more accessible to Italian readers by simplification. ${ }^{22}$ As well as being an inevitable pitfall of translating, losing the innuendos of Shakespeare's language may have been in part a deliberate act by Rusconi. Early continental criticism of Shakespeare is sceptical of the English ability to find 'beaut[y]' or 'merit' of the plays 'in the midst of so much filth' which, coming from the mouths of nobility and royalty, seemed indecent. ${ }^{23}$ However, by the early nineteenth century, critical views of Shakespeare's bawdiness had abated as Romanticism took hold in Italy, and with it came a flurry of translations. A number, including that of Michele Leoni, first

${ }^{21}$ Letter of 2 January 1847; Rosen and Porter, Sourcebook, p. 29.

22 Although Piave was employed as the librettist, Verdi had extremely specific requests and knew the work he wanted to create intimately. When he sent the prose draft synopsis to Piave, he tells the librettist that he 'know[s] the general character and the tinta as if the libretto were already finished.' See letter of 4 September 1846, Ibid, p. 8.

${ }^{23}$ Giovanni Andres, Dell'origine, progessi e stato attuale d'ogni letteratura, Parma: Royal Press, 1785, quoted in Collison-Morley, Shakespeare in Italy, New York: Benjamin Bloom, 1916, p. 28. 
published in 1819, drew as much from French adaptations as the original English source (especially the prominent French translation by Le Tourner). A number of other translations were published in the early 1830s, including Virginio Soncini's prose version of 1830 and Giunio Bazzoni and Giacomo Sornani's versified translation in $1830-1 .^{24}$ At the time Verdi was considering composing Macbeth, Rusconi's version was likely the most readily available, but Weaver clarifies that copies of Leoni's translation and one by Giulio Carcano published in 1848 were probably also used, judging by distinct parallels between all texts with lines in the libretto. ${ }^{25}$ Furthermore, François-Victor Hugo’s French translation and an English copy edited by Charles Knight were both found in Verdi's library at Sant'Agata. ${ }^{26}$

Verdi's Macbeth emulated the life cycles of other Gothic operas composed in the 1840s and 50s. In Italy, Macbeth received a mixed reaction. On the one hand, Florentine critics felt Verdi's score contained some admirable moments - including the Act 1 duet and the sleepwalking scene - and praised the composer for his innovations. ${ }^{27}$ On the other hand, the opera was tainted by Piave's libretto, which was ridiculed in the press, and the fantastic genre was also chided as 'meccanismo da idioti' and not

\footnotetext{
${ }^{24}$ In her early twentieth-century study, Shakespeare in Italy, Lacy Collison-Morley notes Giacinto Battaglia's opinion that Banquo's assassination scene in G. B. Niccolini's Macbet (1830) is 'a model of the way in which Italian verse should be used in the drama', but gives little more information on precisely Niccolini's version was preferable. Despite this, she concludes that Macbet is still inferior to Leoni's version, which situates Macbeth within the context of Shakespeare's other tragedies and the text is annotated and accompanied by Schlegel's essays on Shakespeare. Collison-Morley, Shakespeare in Italy, p. 134.

${ }^{25}$ Most of the translations from the 1830s were never republished, although Rusconi's translation was published in a complete edition of Shakespeare's plays and was still in print approximately a century later. As Leoni's had done before it, Rusconi's translation appears to have gained popularity and longevity for its breadth. William Weaver, 'The Shakespeare Verdi Knew' in Rosen and Porter, Sourcebook, pp. 145-6.

${ }^{26}$ Ibid, p. 148.

${ }^{27}$ Leonardo Pinzauti, 'Verdi's Macbeth and the Florentine Critics' in Rosen and Porter, Sourcebook, pp. $139-41$.
} 
representative of Italian (Classical) style. ${ }^{28}$ However, Verdi's Macbeth still proved exceedingly popular in Italy with eleven productions within a year of the premiere. ${ }^{29}$

Even in France where there was a greater compulsion for the fantastic, many newly-composed operas based on Gothic texts (or that at least had some Gothicflavoured episodes) after the 1830s were not well-received at their premieres and many have never been revived. This is the case with Berlioz's and Gounod's settings of the tale of the bleeding nun, an episode from a particularly gruesome early Gothic novel, Matthew Lewis's The Monk. Berlioz abandoned his setting of La Nonne Sanglante in 1841, leaving only one scene, while Gounod's 1854 version lasted no more than a few performances at the Opéra. ${ }^{30}$ Both composers went on to set Goethe's Faust. Berlioz first set the text as Huit scenes de Faust in 1828 and revised this to become the La Damnation de Faust in 1846, while Gounod's Faust premiered in 1859. Both composers' works initially met with a similar fate to Gounod's incarnation of the bleeding nun tale. Berlioz's 'légende dramatique' lasted two performances in front of an unresponsive audience at the Opéra-Comique. However, the negative public reaction to Berlioz's work was not necessarily due to a lack of interest in the Gothic. The unconventional nature of the Berlioz's 'légende dramatique', and Berlioz's musical language were probably more challenging for his Parisian audience than the Gothic subject matter.

Gounod's opera received a somewhat warmer response after the composer revised the score and had shaken off its half-hearted initial reaction by the time it returned to Paris three years later. The work went on to be extremely popular in the late

\footnotetext{
${ }^{28}$ Enrico Montazio 'Profanation in Four Acts by F. M. Piave', La Rivista di Firenze, 27 March, 1847, quoted in Leonardo Pinzauti, 'Verdi's Macbeth and the Florentine Critics' in Rosen and Porter, Sourcebook, p. 142.

${ }^{29}$ Rosen and Porter, Sourcebook, p. 426.

${ }^{30}$ Anne Williams, 'Ghostly Voices: "Gothic Opera" and the failure of Gounod's La Nonne Sanglante', in Operatic Migrations, edited by Roberta Montemorra Marvin and Downing A. Thomas, Aldershot: Ashgate, 2006, p. 131.
} 
nineteenth century. Thus it seems that the popularity of the Gothic genre in opera remained for most of the nineteenth century, albeit more tenuously compared with the popular appeal of the Gothic around the 1830s. It is curious, however, that new Gothic settings in the second half of the nineteenth century did not take off quickly, or at all, when performance records of Verdi's original Macbeth show its huge appeal in Europe and beyond. In a few years it had reached many cities of Europe and South and North America and its popularity only began to diminish in smaller cities during the $1880 \mathrm{~s}^{31}$ Nonetheless, Paris and London, the cities where reception mattered most, barely feature on the records of Macbeth performances. ${ }^{32}$

A further reason why Macbeth remained popular throughout Italy, in the face of failure in France and England, is that the Italians identified with Verdi himself. Therefore the opera's popularity in Italy was as much because of its composer, who was a positive nationalist figure to Italians, as its Gothic subject and the sentiments expressed through the music. Verdi's name was used as an acronym for the king of Piedmont, Vittorio Emanuele, Re d'Italia, whom many unification supporters wanted to see at the head of a united Italy. Accordingly, shouts of 'viva Verdi' were heard in the theatres. Verdi said in a letter to Lanari, the theatre director of the Teatro della Pergola, that 'The subject is neither political nor religious: it is fantastical. ${ }^{33}$ However, a particular letter to Verdi from Giuseppe Giusti dated 19 March 1847 explains the power of Macbeth's political murmurings and that at least some of the audience responded to the opera's political spirit whether Verdi intended it or not:

The more your work is performed, the more it will be understood and enjoyed: the excellence of certain things is not grasped at once...do not lose the occasion to express in your strains that sweet sadness in which you have shown you can

\footnotetext{
${ }^{31}$ See Rosen and Porter, Sourcebook, pp. 428-453. From this list of performances it is unclear which version was used in productions after 1865.

${ }^{32}$ Ibid.

${ }^{33}$ Ibid, p. 5.
} 
achieve so much. You know that the string of pain is that which finds the greatest resonance within our soul, but pain assumes a different character according to the times and according to the nature and state of this or that nation. The kind of pain that now fills the souls of us Italians is the pain of a people who feel the need of a better future...Accompany, my Verdi, this lofty and solemn pain with your noble harmonies; nourish it, fortify it, direct it to its goal. Music is a language understood by all and there is no great effect that music is not capable of producing. The Fantastic is something which can challenge the intellect; truth challenges both the intellect and the soul. I would like all Italians of genius to contract a strong and full marriage with Italian art, and to shun fair siren songs of foreign liaisons. ${ }^{34}$

It is fascinating to see the terms in which Giusti views the affiliation of the fantastic with the pursuit of a national identity. For him, the fantastic was not merely stage spectacle; rather he suggests that through its allegorical themes it triggers a profundity and internalisation of thought, from which rises a specifically Italian consciousness. Art, and emphatically, Italian art, for Giusti, is capable of political expression in the way that the dramatic action unifies the audience with the operatic characters and with each other. The music moves the audience and the fantastic (ideally) resonates with both their reason and their passions.

A distinct lack of interest in presenting the surrounding Risorgimento politics on stage can be construed from Donizetti's operas. However, Verdi was not like Donizetti in this respect. One of the enduring factors in producing the Italian version of Macbeth was certainly the resonance of the metaphor of past tales of oppressed and displaced nations for the present political situation - a thinly veiled nationalism. By 1847 , the desire for unification had increased, reaching a high point in the 1848 riots. In fact, the riots that broke out in Italian cities in January predate some of the most famous riots of that year around Europe. In addition to wanting to set a fantastical subject, Verdi was also aware of representing the oppressed Scottish people, expressed by his desire to compose a chorus as rousing and affective as 'Va, pensiero' from Nabucco (which

\footnotetext{
${ }^{34}$ Ibid, p. 56.
} 
premiered in 1842). ${ }^{35}$ The opera's final number, 'Vittoria! Vittoria!' provides a positive conclusion to Verdi's one addition to Shakespeare's play: the chorus of Scottish exiles displaced somewhere along the borders of England and Scotland. The numbers 'Patria Oppressa', and McDuff's following aria 'Patria Tradita' are lugubrious contrasts in an idiom strongly suggestive of Risorgimento-associated choruses such as 'Va pensiero' to the triumph of the finale. Macduff's aria is also important conventionally as the tenor's one place to shine. Verdi's patriotism is clear as the Scots are positioned as 'us' to Verdi's Italian audience, providing an emotive push for his contemporaries to eliminate the foreign tyrant trying to conquer them. 'Vittoria! Vittoria!' is a typical rousing Verdian chorus and the Scotch snap in the brass and winds hints at a musical Scottishness. Moreover it is the Highlander, Macbeth, who is seen in Act 4 as the threatening 'other', rather than the Lowlanders like Duncan or Macduff. The sociality of opera and its barely hidden analogy of Italian oppression may have been enough to sustain Macbeth without the allure of the Gothic. However, other operas Verdi composed around the time of Macbeth that are capable of being read in political terms, Attila for example, did not remain in the repertoire to the same extent as Macbeth. ${ }^{36}$ Thus the dramatic subject of Macbeth was probably enough to warrant its success regardless of political vibrations, the outcome Verdi, through his strongly worded letters over the opera's genesis, surely desired.

Verdi's Macbeth was not performed in London until 1976, (albeit appearing in Manchester and Liverpool in 1860). ${ }^{37}$ This is surprising for two reasons: first, Verdi and the London theatre director, Benjamin Lumley, actually believed that composing a

\footnotetext{
${ }^{35}$ Letter of 22 December 1846; Ibid, p. 26.

${ }^{36}$ Attila was poorly received at the premiere, but was popular in the 1850 s (due to its political nature) and then dropped quickly out of favour, having been revived only a few times since. See Roger Parker, 'Attila', in The New Grove Dictionary of Opera, edited by Stanley Sadie, Grove Music Online, Oxford Music Online, http://www.oxfordmusiconline.com/subscriber/article/grove/music/O005185, (26 August 2010).

${ }^{37}$ Rosen and Porter, Sourcebook, p. 45.
} 
Shakespearean opera for England was befitting. When he was contracted by Lumley to compose an opera for Her Majesty's Theatre for the 1848 Carnival season, Verdi first resolved to set King Lear, a subject that had been playing on his mind, but was to plague him for many years. ${ }^{38}$ Secondly, it is surprising that Macbeth should remain unperformed in a country where Verdi's operas had already proved so popular. ${ }^{39}$ Neither the appeal of the Gothic nor of Shakespeare had diminished in Britain as it had elsewhere, thus the nonappearance of Macbeth in London cannot be entirely explained by the changing taste of opera patrons. Macbeth was criticised after its opening in Paris for lacking grandeur and spectacle, despite Verdi's 'desire to do a very good job of staging the third Act', using terror-inducing effects and machinery. ${ }^{40}$ After its dismal run at the Théâtre-Lyrique, it was absent from the Parisian stage for more than a century. This outcome was not what Léon Escudier, a publisher and the impresario of the Théatre-Lyrique, foresaw when he learnt that the Paris Macbeth would be pitted against the opening of Meyerbeer's L'Africaine at the Opéra. ${ }^{41}$ He wrote to Verdi that:

They are planning to present L'Africaine [at the Opéra] in February; Cavalho [the Théâtre-Lyrique's manager] - and he's right in this - wants to set up Macbeth in rivalry to the Opéra, in music, in décor, in execution. I'm sure in advance that it won't come off second-best...

\footnotetext{
${ }^{38}$ King Lear was later abandoned in favour of setting Byron's Corsair. However, after a bout of ill health Verdi withdrew from the London commission. The opera was rescheduled, and Verdi eventually set Maffei's libretto I masnadieri, based on Schiller's Die Räuber. I masnadieri was the other work in contention for the Florence commission that produced Macbeth, and the choice of which one would be used for which city was based on the availability of singers. See Kimbell, Verdi in the Age of Italian Romanticism, Cambridge: Cambridge University Press, 1981, pp. 193-4; Verdi's letters of 19 August 1846 and 4 September 1846, Rosen and Porter, Sourcebook, pp. 5 and 8.

${ }^{39}$ Jennifer Hall-Witt shows that between 1842 and 1851 eleven percent of the repertoire of the King's and Her Majesty's Theatre was devoted to Verdi's operas, which then climbed to twenty-four percent in the period of 1852-1861 as Bellini and Donizetti lost their monopoly as the composers of more than half of the operas performed at the theatre. She also highlights that the trend was to produce operas that were a few (or more) years old, rather than new works, essentially building the canonical operatic repertoire. See Jennifer Hall-Witt, Fashionable Acts: Opera and Elite Culture in London 1780-1880, Lebanon: University of New Hampshire Press, 2007, pp. 297-8.

${ }^{40}$ Letter of 21 January 1847, Rosen and Porter, Sourcebook, p. 33.

${ }^{41}$ Nor was it foreseen by Giuseppina Strepponi when she writes that Macbeth 'is one of the subject's that's best suited to the French stage'; Letter of 23 February 1847, Ibid, p. 43.
} 
Famous last words from the impresario, for as Porter and Rosen note, less than a year later, Meyerbeer's opera had received a hundred performances and Macbeth only a total of fourteen. $^{42}$

The success of Gounod's Faust would seem to demonstrate the continuing popularity of Gothic interpretations in France (and Germany) particularly. ${ }^{43}$ Its themes place it within the Gothic genre, but whereas Gothic topics were decreasingly called upon for new operas, the portability of the Faust legend is evident through centuries of adaptation, peaking in the Romantic era when it became one of the most prevailing musical subjects. The first volume of Goethe's celebrated Faust was translated into French by Gérard de Nerval in 1828 (at the height of translations of German and English Gothic literature and drama into French and Italian), but most musical adaptations of the nineteenth century, both dramatic and symphonic, were not produced until the second half of the century. Faust's popularity may be accredited to the operatic potential of Part I, Part II being too metaphysical and esoteric to translate easily to the stage. Part I is a remarkably fantastical fable, engirdled by the demonic and Faust's anxiety of being condemned to eternal damnation. The story nonetheless contains some (minor) reprise early on in scenes of the pastoral and village life. (Indeed, it has some similarities with Mozart's Don Giovanni, which was popular with Romantics). Thus Faust's themes are somewhat more balanced between the Arcadian and the underworld than Macbeth's, in which almost every scene is steeped in subversion, hunger for power and occult belief.

After Berlioz and Gounod had completed their Faust settings, Arrigo Boito (Verdi's Otello librettist) composed his Mefistofele for an 1868 La Scala premiere -

\footnotetext{
${ }^{42}$ Letter of 25 November 1864, Ibid, pp. 74-5.

${ }^{43}$ In addition to operas, a number of symphonic works are indebted to Goethe's Faust, including Liszt's Eine Faust-Symphonie in drei Charakterbildern and the second part of Mahler's 8th symphony.
} 
which was a debacle. As with Gounod's earlier work, Boito's opera had to undergo a resurrection to achieve success. It took him a second attempt - his revised version of 1875 - to win over audiences, although William Ashbrook notes that the opera now exists on 'the fringes of the modern repertory', not falling off the radar entirely because of the strength of the prologue and the prison scene. ${ }^{44}$ Interestingly, the subjects of Macbeth and Faust coalesced in some of the earliest music based on both works. Louis Spohr composed his Faust in 1813 (with an 1816 premiere) and in the late 1820s, it had become standard practice to insert the overture from his Macbeth, (incidental music composed in 1825, rather than a staged work), to open the third Act of Faust. This link was not necessarily one devised by the composer himself, but is evidence of the thematic compatibility of the two works and is certainly an act of self-borrowing as appropriate as many found throughout the Italian operatic repertory. Spohr, too, later revised his Faust for London after much persuasion, where it premiered at the Royal Italian Opera in 1851 in a production that proved as popular as the original. ${ }^{45}$

Spohr's Faust, one of the few Gothic operas composed in the later nineteenth century, found success in Paris while Macbeth and other Gothic operas initially did not. Reviews of the Parisian premiere of Macbeth illustrate that, despite the opera following a successful season of Mozart's Magic Flute, the French were bored with the fantastical colour and spectacle and one reviewer in particular felt that Shakespeare 'often eludes M. Verdi' ${ }^{46}$ The accompanying note in the Macbeth Sourcebook indicates that Escudier, the impresario of the Théâtre-Lyrique, may have forwarded this review to the composer, prompting Verdi to defend his claim to familiarity with Shakespeare's work.

\footnotetext{
${ }^{44}$ William Ashbrook, 'Boito, Arrigo', In Grove Music Online, Oxford Music Online, http://www.oxfordmusiconline.com/subscriber/article/grove/music/03430, (13 May 2010).

${ }^{45}$ Berlioz considered revising Faust as an opera for the London stage London around the same time, under the new title of Mephistopheles because of the popularity of Spohr's opera.

${ }^{46}$ Paul Ferry, review of Macbeth in La Comédie, 23 April 1865, in Rosen and Porter, Sourcebook, p. 405.
} 
The criticism of the opera's element of spectacle, in face of Verdi's choreographed additions, and the comparison with other operatic failures emphasises its supposed lack of variety and deficient dramatic technique. The same reviewer for La Comédie notes that the chorus of assassins in Act 2 is 'reminiscent for its situation, of the chorus in the second Act of Lucrezia.' Moreover, this review was by no means the only that, while recognising the dramatic value of parts of the work, overall rejected Macbeth as monotonous and unable to keep the audience in their seats. An irreverent review was also published in Le Guide Musicale:

The audience were fatigued, enervated by the uniformity of the scenic apparatus, and the music had not succeeded in holding their interest...Macbeth is a magnificent drama; it is the least musical subject in the world. It lacks variety; heartfelt poetry, sentiment, contrasts are not there. For a composer, it was an arid, ungrateful subject. M. Verdi, as luck would have it, was not served inordinately well by his imagination: I consider this to be one of his weakest works. $^{47}$

An obvious reason for the apathy shown to Macbeth in Paris is precisely what sets it apart from Faust settings: its lack of contrast between the Gothic and antithesis scenes of picturesque village life. Another reason, and one highlighted by other reviewers, is the opera's non-existent love story, as the only love is a disillusioned quest for power. ${ }^{48}$ Macbeth has perhaps travelled too far towards the Gothic at the expense of scenic contrasts and the conventional inclusion of a love story. Verdi, in his attempt to extend the dramaturgy of opera has, unwittingly or not, perhaps shifted opera to a place his foreign audiences were not entirely ready for, or did not want to venture to. Yet the 'love story' is not a device unique to opera; the majority of Gothic literary works have a romantic subplot. In channelling Shakespeare Verdi renounces that possibility, for the original lacks a typical romantic thread, although there is a compelling relationship of

\footnotetext{
${ }^{47}$ Jules Ruelle, review of Macbeth in Le Guide Musicale, 27 April 1865, in Ibid, p. 407.

${ }^{48}$ See, for instance, the review of 29 April 1865 in Le Monde Illustré by Albert de Lasalle, Rosen and Porter, Sourcebook, pp. 407-8.
} 
respect and shared ambition between the Macbeths, at least initially. Instead of usual operatic love, there is an atmosphere of sexual tension in the original that, as Christophe Clausen explains in his Macbeth Multiplied, is subdued in the libretto. ${ }^{49}$ Verdi's opera senza amore is also without a tenor lead (the reason I masnadieri was not performed in Florence) and a heroine with whom the audience is able to pity or sympathise with in her plight - at least until Act 4. Thus Verdi's dramatic endeavour appears revisionist, one that would either alienate his audience or heighten his fame. Both of these outcomes eventuated with Macbeth. Macbeth's success in Italy in its original version, then later rejection in Paris and rapidly declining Italian productions suggests it may have been Verdi's adaptation that audiences did not respond favourably to. The 1865 version for Paris introduced stylistic inconsistencies through Verdi's inclusion of sections composed in his more mature style. However, the Paris version (without the ballets) is usually performed today.

For the Paris Macbeth, Amilcare Ponchielli's statement that 'if the management has to make money, one has to make oneself understood by all the public, including the clockmaker, the coal merchant and the sealing-wax vendor' appears to ring true. ${ }^{50}$ Macbeth's career was ended before it began in Paris: the dearth of a romantic (sub)plot, star tenor, forlorn heroine and the grandiose fantastical effects moving too far from audience expectations.

\footnotetext{
${ }^{49}$ Clausen explains that the witches talk and actions are embedded with phallic symbolism, although this is within areas of the play Verdi has removed. He further investigates links between Lady Macbeth's brutality and sexuality. See Christophe Clausen, Macbeth Multiplied: Negotiating Historical and Medial Difference between Shakespeare and Verdi, Amsterdam and New York: B. V. Rodopi, 2005, pp. 47 and 99-101.

${ }^{50}$ Quoted in and translated by Jay Nicolaisen, Italian Opera in Transition: 1871-1893, Ann Arbor: UMI Research Press, 1980, p. 114.
} 
'Il sol cruento mio pensier la dà forma' ${ }^{51}$

The opera opens with Shakespeare's third scene, directly after King Duncan has sent the Thane of Ross to greet 'noble Macbeth' with his new title - Thane of Cawdor following a victorious campaign against the Norwegians. ${ }^{52}$ After agreeing to meet Macbeth 'upon the heath' after the battle in the first scene of Shakespeare's play, the witches return in the third scene. They are plotting vengeance in a sequence that shows how Verdi and Piave - under Verdi's direction to 'ALWAYS BEAR IN MIND; USE FEW WORDS...FEW WORDS...FEW, FEW BUT SIGNIFICANT' - pruned Shakespeare into dramatic concision. ${ }^{53}$ The first scene is set in a Scottish forest and in the midst of a storm the witches are visible, surrounded by thunder and lightning. They have multiplied in the opera from Shakespeare's three individuals, to three groups, and part of their operatic power lies in their numbers, as they dominate the stage in their scenes with Macbeth.

Even more than their dominating stage presence, the witches become 'operatically enabled' in Verdi's Macbeth, musically exercising influence over the Macbeths and passing between realms within and beyond the stage. Just as the spectre Lucia envisions has demonic connections, the witches in Macbeth are relentlessly associated with darkness and the satanic. They are transient, existing on a plane between their corporeality and supernatural planes - even in the natural world Macbeth encounters them in, they occupy the borders of society and are able to seemingly materialise at will. In Abbate's metaphysical terms, the witches straddle the phenomenal and noumenal horizon, invoking access to the beyond.

${ }^{51}$ [Only my bloody imagination gives it form.]

52 Shakespeare, Macbeth, p. 971, 1. 67.

${ }^{53}$ Ibid, p. 971, 1. 7; Letter of 22 September 1846; Rosen and Porter, Sourcebook, p. 10. 


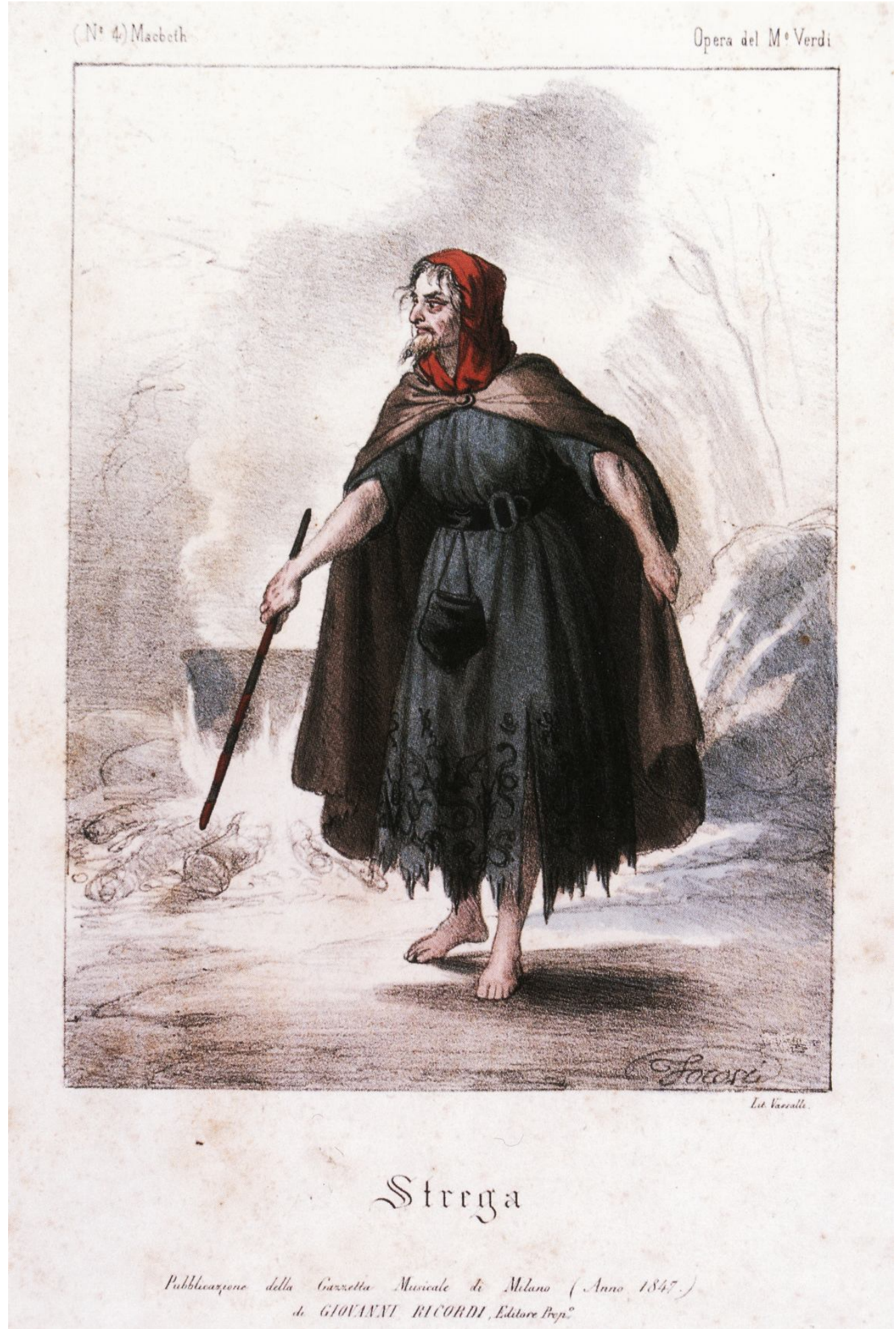

Figure 3.5: Costume for the witches in Verdi's Macbeth (Venice, Teatro la Fenice, 1847).

Besides this other-worldly association, Shakespeare's witches are androgynous in a way that is less apparent in Verdi's opera, where they are voiced by a women's chorus, 
rather than being played by men as was required in Elizabethan England. Nonetheless, originally there was a conflation of gender, not so distant from operatic trouser roles. The witches' beards cause further issue in the play and the opera, in which Banco tells them 'Dirvi donne vorrei, ma lo mi vieta / Quella sordida barba', ['I would call you women, but I am forbidden by / those grimy beards']. As a result, the witches transgress boundaries of physicality with their ambiguous gender, marginal in every sense (figure 3.3).

Henry Füssli's paintings of scenes from Macbeth, completed in the 1780s for John Boydell's Shakespeare gallery, also depict the witches as gender-transgressive. ${ }^{54}$

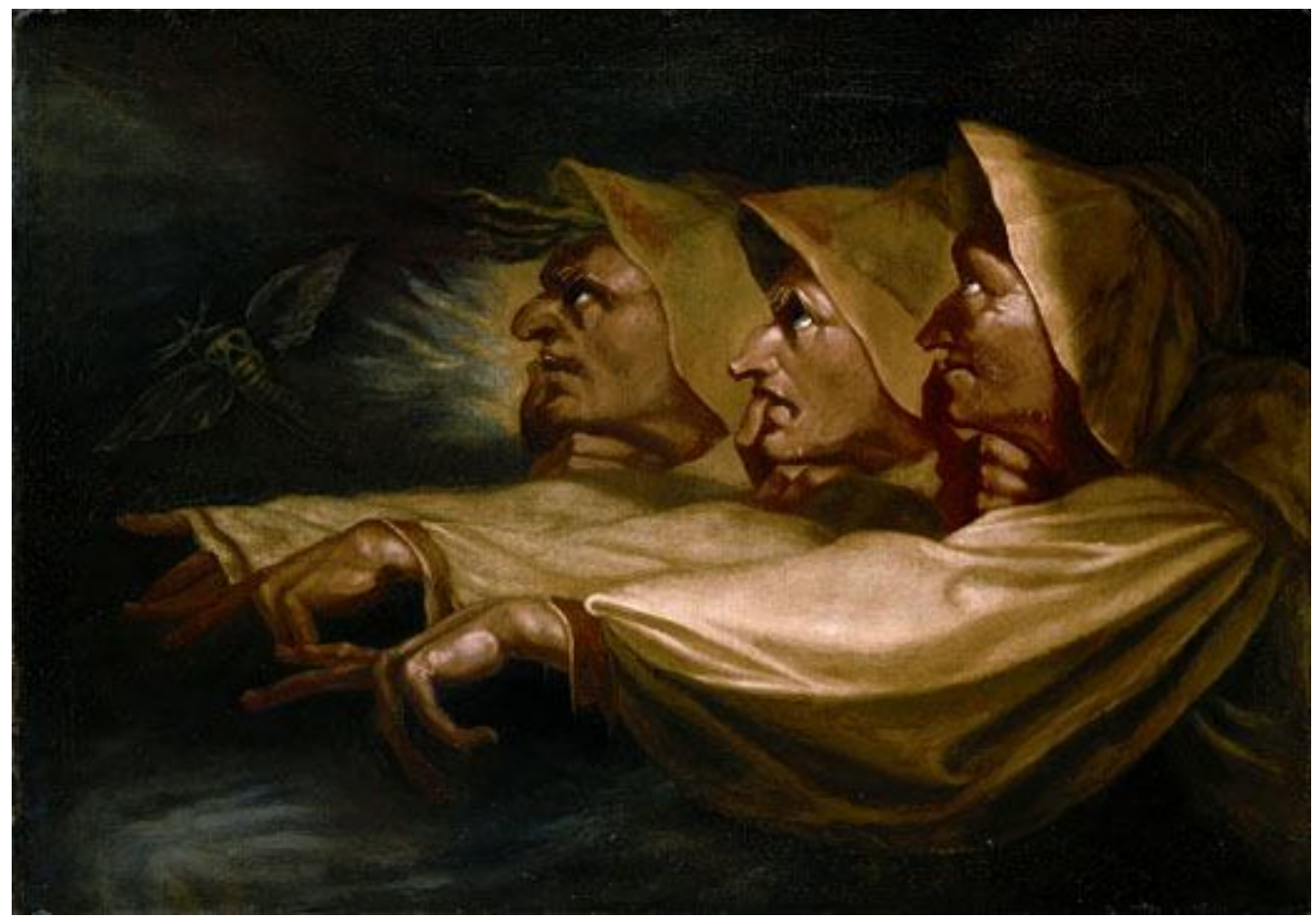

Figure 3.6: Henry Füssli's Three Witches (1783). Photograph courtesy of the Collection of the Royal Shakespeare Theatre/The Bridgeman Art Library.

His Three Witches (1783) is one of his lesser known, and certainly less discussed works (figure 3.4). ${ }^{55}$ In the painting, as opposed to sporting beards, these witches are hairless

\footnotetext{
${ }^{54}$ Georg Paula and David Blayney Brown, 'Füssli', in Grove Art Online, Oxford Art Online, http://www.oxfordartonline.com/subscriber/article/grove/art/T030261pg3, (20 June 2010).
} 
and ageless; their fingers are outstretched and gnarled, as unnaturally contorted as their noses. The witches have their fingers crooked in their mouths and their faces betray a mixture of secretiveness and satisfaction. Most of all though, their gender is confounding: the farthest witch is the most masculine, the centre one appears hermaphroditic, while the witch in the foreground is the most feminine, despite the usual assumption that, whatever the gender of the witches', it is at least all the same. The effect builds on the sense that the witches are able to transform themselves, as all three are in the same position, almost captured as a time-lapse of gender-morphing. Füssli's painting literally illustrates the issues of gender and boundary-crossing more generally surrounding the witches that occupies Verdi's opera. ${ }^{56}$ Musically, the type of harmonic and rhythmic irrationality that often torments operatic women stains the witches. Their music is most similar to Lady Macbeth's, although this could suggest their common purpose, rather than a purely gender-associative sound, as in moments of madness Macbeth stimulates their musical reprise. In the opera, the ability of the streghe to transcend harmonic boundaries only serves to mirror their ephemeral and marginal role.

Schlegel's criticism of Macbeth, which was printed in Verdi's copy of Leoni's translation, refers to the human essence of superstition and its faculty to provoke the imagination:

No superstition can be widely diffused without having a foundation in human nature: on this the poet builds; he calls up from their hidden abysses that dread of the unknown, that presage of a dark side of nature, and a world of spirits, which philosophy now imagines has altogether exploded. ${ }^{57}$

\footnotetext{
${ }^{55}$ Scholarly activity is focused rather on Füssli's other paintings of supernatural and monstrous creatures, most prominently his Nightmare.

${ }^{56}$ Notwithstanding the improbability that Verdi or his collaborators would have seen the exhibition Three Witches was included in, which did not travel to Italy and had long closed by the time Verdi was in England, it places the composer's interpretation within a wider context of interpreting Shakespeare's witches.

${ }^{57}$ Augustus William Schlegel, Course of Lectures on Dramatic Art and Literature, translated by John Black, London, 1846. New York: AMS, 1973, p. 408.
} 
While 'witches' were originally sage women, their extensive knowledge of the natural landscape - particularly its plants and their medicinal properties or uses - was feared because it was not understood, and people resorted to explaining their 'unnatural' activities as magic or sorcery. Alchemic skills, manipulating or transforming 'ingredients' - whether in healthy or unwholesome ways - was seen as threatening, and communicated the sinister insinuations of the term 'witchcraft'. Historically 'witches' strayed at the edges of social boundaries, the lowest of the social order (along with the insane), which consequently increased their mysteriousness and roused further superstition from their communities. Indeed, Anne MacVicar Grant charges 'the belief in witchcraft' as 'the worst result of supernatural agency...[a] cruel and abject form of superstition, 58

This description of witches suggests precisely the type of character Walter Scott's Old Alice is accused of being by Henry Ashton and Edgar Ravenswood in The Bride of Lammermoor, reinforcing the strong suspicion of women on the outskirts of Scottish society. Old Alice is blind, relying on insight and divination over sight, and she dislikes the Ashtons' control - she is as sceptical of them as they are of her. Any undertones of witchery or the other-worldly are completely erased by Cammarano in his overhaul of the novel (when she is conflated with other characters and reduced to the status of Lucia's handmaid), thereby diluting Gothic potential for Lucia di Lammermoor. It is Verdi's retention, if not dramatic exaltation, of the witches that over-reaches Donizetti's Gothic imagination for the fantastically diabolic.

\footnotetext{
${ }^{58}$ Anne MacVicar Grant, Essays on the superstitions of the Highlanders of Scotland: to which are added, translations from the Gaelic; and letters connected with those formerly published in Two Volumes by the author of "Letters from the mountains." London: Longman et al, 1811, pp. 97-8.
} 
Among the most potent of myths were those in which 'witches' were believed capable of summoning the dead or conversing with spirits and infernal powers, and Schlegel's comments infer that the witches themselves, represented as logically inexplicable, are superstition objectified. They are only present because human nature has fuelled a fear of the unknown and allowed imagination to surmount reason. The witches are powerful and thought-consuming in Macbeth because they are confined to neither internal thought nor the physical worlds. They are allowed to saturate all facets of the drama because Macbeth empowers them through actively seeking to realise their augury, the domain of the Weird Sisters is thus able to expand in the opera as a visible impression of the noumenal limits.

This is perhaps the difference between Abbate's nomenal and Tomlinson's narrower view of the term - for the witches pertain to both distinctions. To be phenomenal under Abbate's terms, they must 'perform' and consciously interact with music as a source of the opera's diegesis, their noumenal-phenomenal crossing occurring at ruptures within the narrative. Tomlinson presses for a more self-conscious annunciation, which is evident in the Macbeths' music, but less so in the witches where it is questionable that they depict the same level of self-awareness. As part of Abbate's noumenal, they seem to infiltrate the sound world of the opera even when they are visibly absent, and as part of Tomlinson's they depict moments of Gothic conglomeration.

Like Verdi's witches, those of Shakespeare sing, setting musical precedents for display with a vocal number at Hecate's entrance before the apparition scene. The witches' musical language in the first scene of the opera permeates much of the score, particularly in Gothic instances of supernaturalism. They accomplish a performance to some extent in the opening scene, although whether they are a source of music and not 
just of sound acts as a reminder of their ambiguity. Their diabolical chants reside partway between operatic 'speaking' and 'singing'. They are the only characters to vocalise in any manner apart from speech in Shakespeare's play. How the witches utter their lines is as important as what they say, and just after the first entrance of the streghe Verdi marks on the score 'staccate e marcate assai: né dimenticarsi che sono streghe che parlano' [detached and accented: nor forget that they are witches who speak]. The strongly rhythmical first section of the chorus suggests it is more emphatic than conventional recitative - and structurally it acts as both the scena and allegro - but as 'speaking' it does not have the melodic qualities of conventional chorus music in the way that their allegro does (example 3.1).

After the drum interrupts their vengeful banter to announce Macbeth and Banco's approach, the dance they perform, now together instead of as three groups, calls into question whether their song is in fact phenomenal, or if they are dancing to an abstraction of internal music (example 3.2). Any melodic accompaniment to the witches' vocal line is limited to imitation, with rhythm and some embellishments the only additions; the doubling of the orchestral accompaniment is compelling evidence to interpret their dance as phenomenal. Therefore Verdi gives his witches' dance a narrative purpose, likely inspired by Meyerbeer's narrative 'ballet of the nuns' from Robert le diable. This imitative accompaniment further depicts that the witches do not have multiple musical consciousnesses: they constantly shift between the phenomenal and the noumenal voice of Macbeth's subconscious when they cannot be seen performing on stage. They are Macbeth's imagination, and Verdi objectifies this through Macbeth's interactions with them, creating a tension between this noumenalism and the witches' tangible forms. ${ }^{59}$ 
Example 3.1: Witches' chorus, from Act 1, scene 1 of Verdi's Macbeth, bb. 52-7.
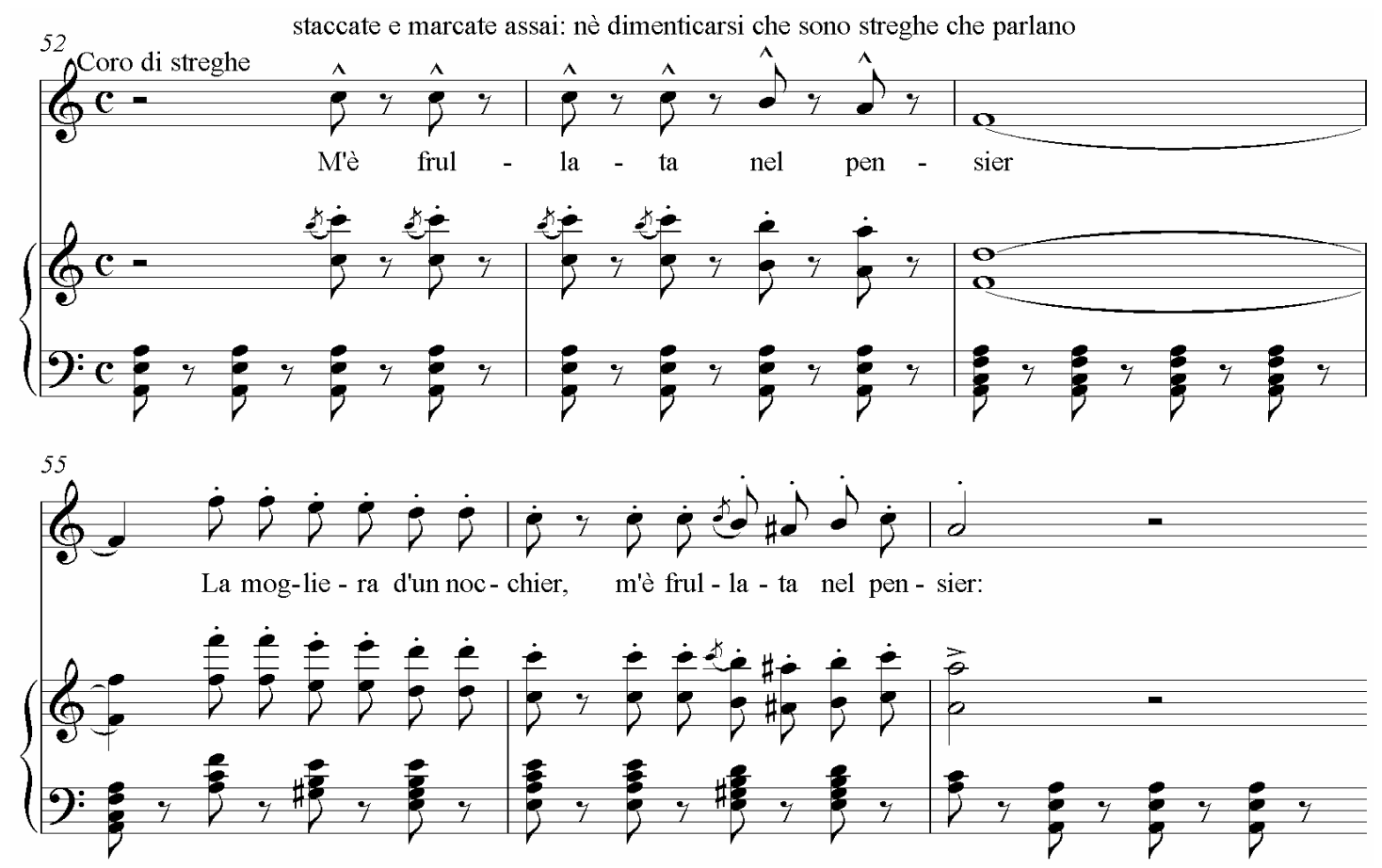

The audience witnesses them on stage and can hear their music, but is also aware of them musically when they are invisible through their audible influence in not only Macbeth's mind, but also in that of Lady Macbeth, particularly in those places where she assimilates her husband's musical language or where the witches are described. Therefore, rather than remaining submerged within the characters' consciousness, as Tomlinson believes is the case, the witches are in full flight; Macbeth's noumenal limit is bared for all to see through their phenomenal sound. The effect of this is unlike the noumenal surfacing of the ghost in Lucia's cavatina, for the ghost is mute and relies on Lucia to envoice her through the music of her subconscious. 
Example 3.2: Drum interruption and Allegro of witches' chorus from Act 1, scene 1 of Verdi's Macbeth, bb. 90-120.
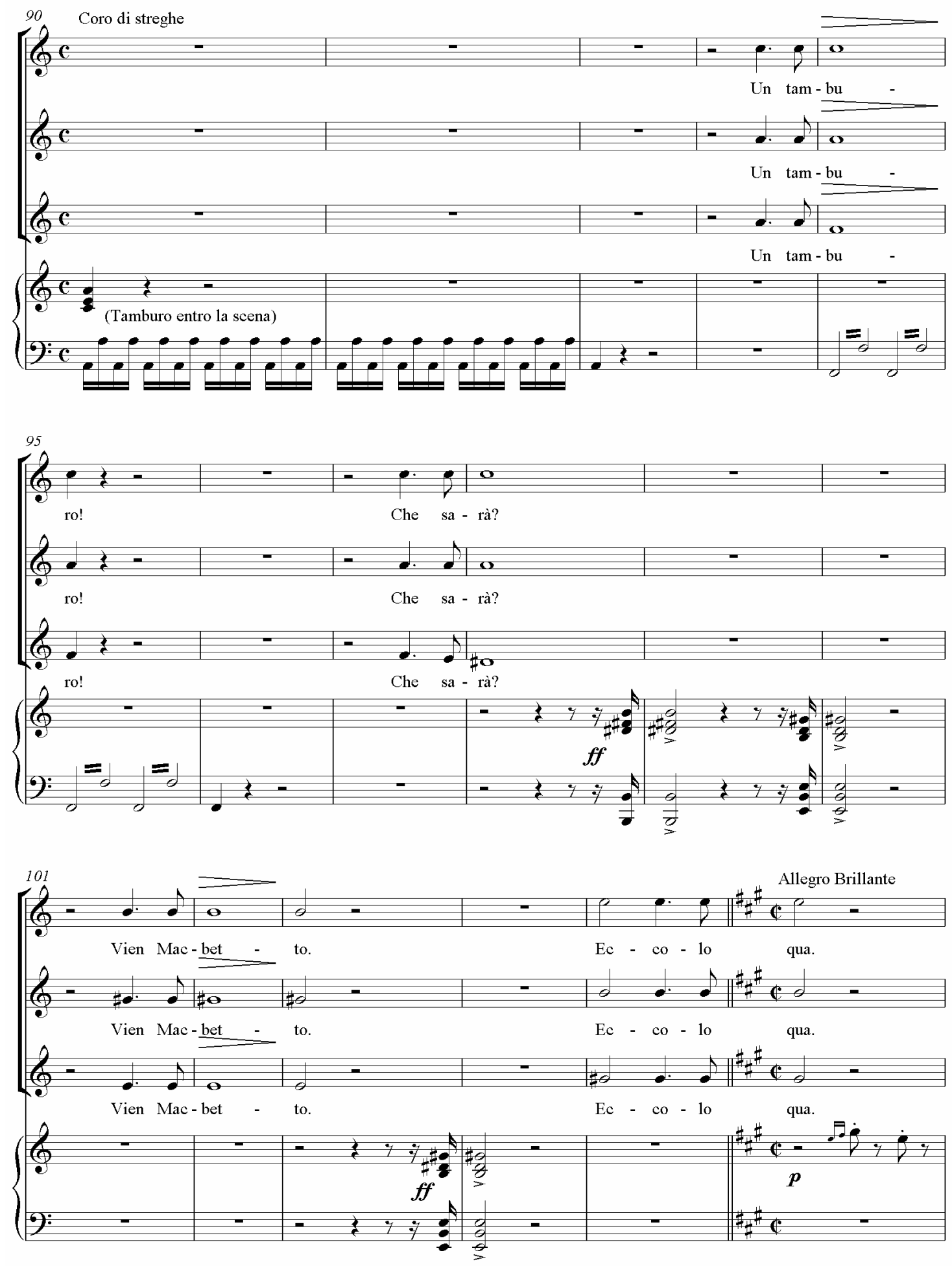
2

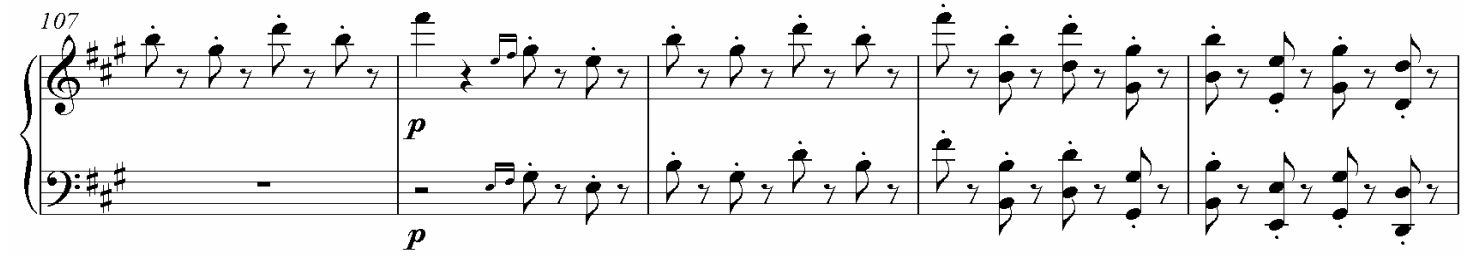
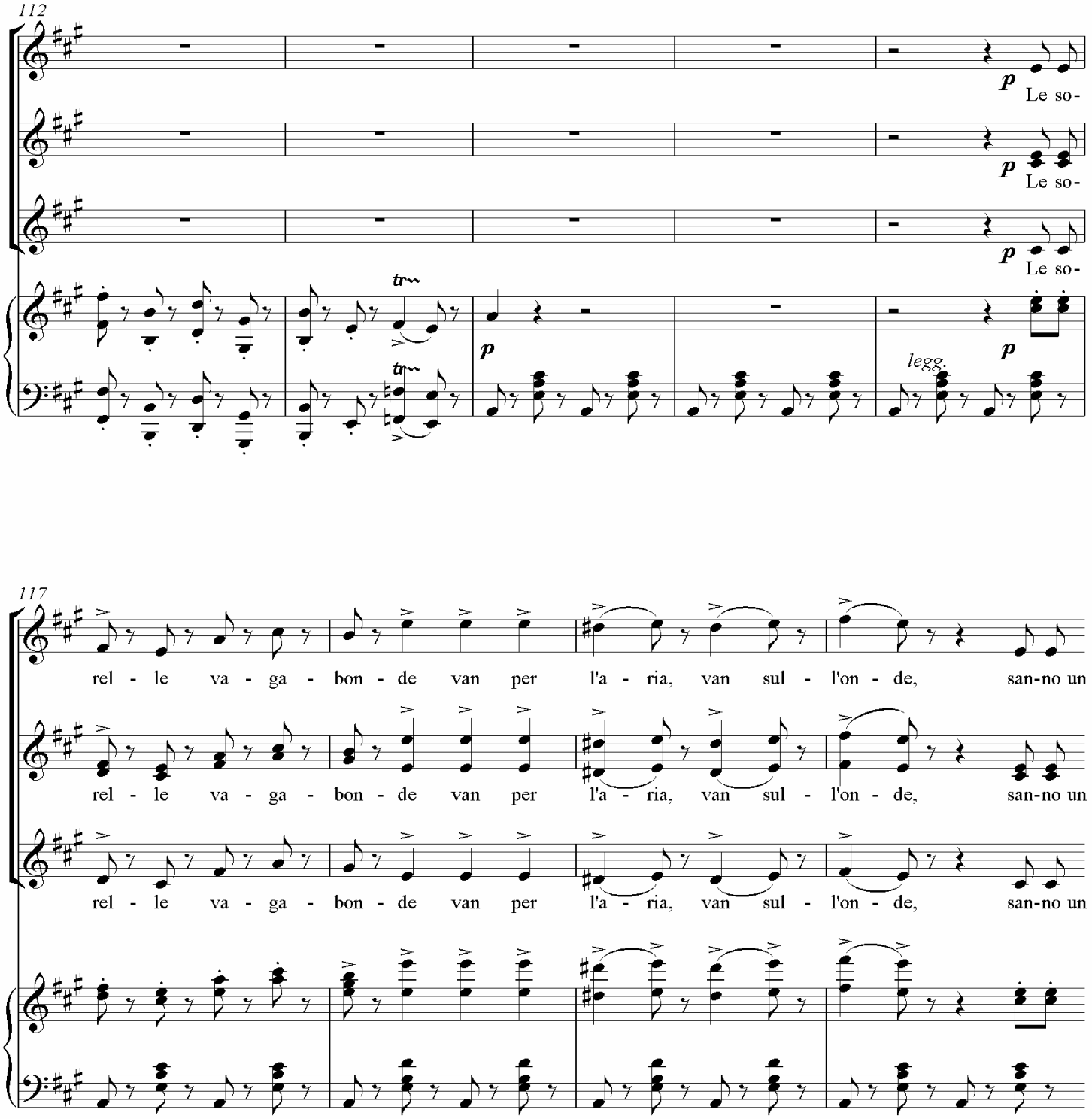
The witches are characters that show awareness of their musical surroundings and their voices, and because of this they shift between the phenomenal and noumenal sound worlds of the opera.

As performers, the witches in the apparition scene continue to vacillate between worlds. Their movement, particularly in the ballet where they appear to be consciously performing, equates to a phenomenal dance. Instead of using voices here, they express the diabolical episode through gesture, highlighting again their gender transgression and their physicality. Through the physicality of their dance they express themselves in a rudimentary language more rudimentary and less rational than that of words. Indeed, even when they do sing, much of their time is spent moving, circulating around a cauldron. Although their accompaniment channels their earlier vocal music in its character, proving an incantation of sorts though the limited variation in pitch and the detached, rapid (allegro vivacissimo), dotted figures. The witches, 'topped up' with infernal spirits, dance three ballets after their chorus at the opening of the third Act. The dances are problematic in defining the witches' noumenal-phenomenal position, as it appears that, unless these 'midnight hags' are using their voices, their 'own' music is subordinated to other forms of musical expression. The uncanny jolting that musically expresses the supernatural in the first Act is dulled down in the first ballet, although their visual objectification is no less horrifying.

As earlier, the act of dance implies they are responding to this music - or to an internal 'music of their master', in preparation for the apparitions. The first apparition is the armed head, musically conjured by the brass opening. This instrumentation also hints at the type of exotic dance typically required by French operatic traditions, and looks toward the brass march announcing Duncan's arrival and the patriotic 'Scottish' music of the final Act. The first ballet almost functions as prognostication, musically 
anticipating the first apparition, but Verdi does not sustain a similar effect in the second two sections. In the second two dances the woodwind typify the music as representing the 'otherness' of madness and supernaturalism. The style of writing Verdi associates with the witches are staccato, step-wise or disjointedly jerky melodic constructions, and exaggerated rhythmical accents. These mannerisms are evident in each of the three ballets added for the Paris version of Macbeth, but the witches act as musical serpents, twisting between styles, as at Hecate's entrance in the second ballet they provide their (or at least her) deceptive power through uncharacteristically long, lyrical phrases. In fact, the apparent juxtaposition created here between character and music would act to dignify the Weird Sisters musically if only they were not inciting the macabre by dancing around a cauldron with diabolical creatures. The final part of the ballet scene is a grotesque waltz, a literal signification of what is on stage. The leaping melodic line takes their otherness to an extreme (example 3.3).

Example 3.3: Waltz from the third of the witches' ballets from Act 3, scene 1 of Verdi's Macbeth, bb. 207-14.
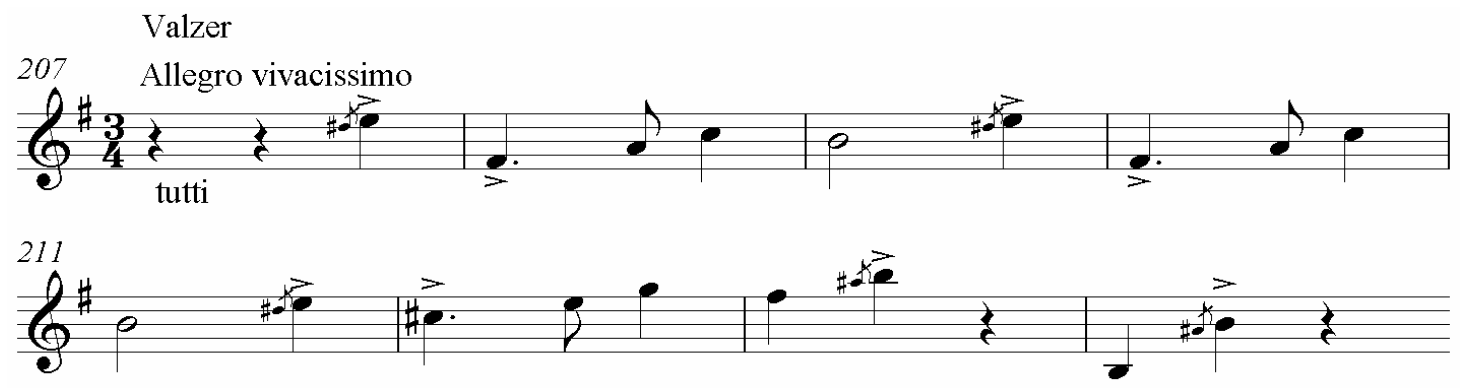

While the ballets evoke the macabre tinta of the opera for the most part, the musical depiction of the witches is a point where Verdi's later style characterises the witches in a musical language somewhat different from their earlier scenes. The music of the Parisian ballets undermine any interpretation of the witches' as a noumenal force as the 
music bears little connection with their characterisations in the rest of the opera and their dance does not function dramatically.

After performing a ballet spectacle as part of the French grand opera traditions, the witches are not part of the audience's subconscious in the same way as they appear to the Macbeths. More precisely, only Macbeth sees the witches in this scene and Lady Macbeth never lays eyes on them. For her, they exist only as an imaginary fabrication from what Macbeth relates back to her about them, and he refers to them only as 'veggenti' [seer or oracle], 'profetesse', 'misteriose donne' or, as Verdi also labels them, 'streghe, ${ }^{60}$ In Shakespeare's play, Macbeth is more forthcoming in his description, recording in the letter he sends to Lady Macbeth:

They met me in the day of success, and I have learned by the perfect'st report they have more in them than mortal knowledge. When I burned into desire to question them further, they made themselves air, into which they vanished... All that impedes thee from the golden round Which fate and metaphysical aid doth seem To have thee crowned withal. ${ }^{61}$

In the first part of the letter, Macbeth is so overcome by his prophetic experience that he is unable to metrically restrain his thoughts, tumbling into prose in much the same manner as Lady Macbeth's agitation and confusion is expressed in her sleepwalking scene. The operatic Macbeth's limited description of the witches gives the impression that the inner imagination is revealed only in the witches' actions: Macbeth does not refer to their methods of prophesising, only the outcome. The scenes with only the witches emerge to the audience as Macbeth's imagination coming alive. Comparable to Lucia's vision, he is the only one who sees them 'in action'. Although Banco hears their predictions, they cease their dancing and utterances of sorcery before the men arrive and Banco is able to dismiss what he has seen relatively quickly - after all, they

\footnotetext{
${ }^{60}$ It seems appropriate that the term 'veggenti' is a neuter noun, void of a gendered ending.

${ }^{61}$ Shakespeare, Macbeth, p. 974, 1:5, 11. 1-5 and 27-9.
} 
give no forecast for him personally. Rather, Banco must rely on the outcome of earlier events from which his future generations will gain the throne. On Macbeth's second meeting with the witches, he orders the soldiers accompanying him to wait silently, out of sight, while he approaches the hags. The workings of his mind are illuminated for the audience in a way unlike earlier Gothic operas. Moreover, this creates a markedly different effect to Lucia's vision at the well. We 'see' her subconscious reliving of the memory only musically and it remains an abstract form for the audience because it is given no concrete visual representation.

The witches in the play speak in verse, a higher form of expression than the prose that is usually associated with marginalised characters, whether mentally or socially. In Shakespeare's Macbeth, the porter (who is removed from Verdi's opera), doctor and lady in waiting are the only characters in the play not given verse, with two exceptions (including the first half of Macbeth's letter). Shakespeare uses prose form to signify the mental decay of Lady Macbeth in the same way Lucia, disturbed by the ghost and her own mental instability, is unable to retain her musical form in her cavatina and the initial part of her mad scene. Assigning the witches' verse could almost be seen to glorify them, allowing their knowledge and insight (or perhaps even magical power) to surpass their position at the bottom of the social spectrum. When adapted for opera, this allows Verdi to save moments of prose speech for madness alone, the best example being Lady Macbeth's mad scene and the breakdown of solita forma. Moreover, due to Verdi's extensive treatment of the witches and their fundamental importance to the opera, Verdi (and Piave) reflect a similar interpretation of the witches to those heard in literary criticism of the eighteenth and nineteenth centuries, in which they are perceived as ennobled: they are given the profundity of a chorus of Classical tragedy. Perhaps this is hardly a novel interpretation of the witches' 
function, given the strong operatic and dramatic traditions of the chorus acting as a vehicle for social or moral commentary, yet they remain ambivalent, simultaneously representing both a crude triviality and the frightening appeal of the Gothic.

Friedrich Schiller's adaptation of Macbeth, published in 1801, was known to Andrea Maffei, who translated Schiller's Macbeth from German to Italian in 1863, but was aware of it well before then. ${ }^{62}$ Schiller modelled the witches on Greek chorus traditions, and also compounded their gender-ambiguity after the fashion of Shakespeare by giving the parts to men. ${ }^{63}$ The duality of the witches' purpose and effect in Macbeth had already been famously discussed by Schlegel, whose criticism of Schiller consequently influenced Coleridge, who concluded that:

In Macbeth, the poet's object was to raise the mind at once to the high tragic tone, that the audience might be ready for the precipitate consummation of guilt in the early part of the play. The true reason for the first appearance of the Witches is to strike the key-note of the character of the whole drama, as is proved by their re-appearance in the third scene, after such an order of the king's as establishes their supernatural power of imagination. ${ }^{64}$

Coleridge's 'supernatural power of the imagination' is useful in describing the Gothic in Verdi's music. It links together a number of literary concepts about the Gothic with those related to opera studies, including the subversion and undercutting of the Classical by the Gothic. The phrase also underlines the refusal of Macbeth to fit the dichotomy between the male and female Gothics, which is thrown into a spin firstly by the dominating role of Lady Macbeth, and secondly by the inexplicable nature of supernatural events as part of the male-driven Gothic.

\footnotetext{
${ }^{62}$ Maffei was the poet and translator who revised some scenes of the libretto for Verdi after Piave did not complete it to the composer's satisfaction; Daniel Albright, Musicking Shakespeare, p. 148. ${ }^{63}$ Ibid, p. 149.

${ }^{64}$ Samuel Taylor Coleridge, 'Notes on Macbeth' in The Literary Remains of Samuel Taylor Coleridge, Vol. 2, edited by Henry Nelson Coleridge, London: William Pickering, 1836, pp. 238-9. Originally presented as a lecture on 14 January 1819 at the Crown and Anchor Tavern, London.
} 
Example 3.4: 'Tutto è finito' motive from Act 1, scene 4 of Verdi's Macbeth, bb. 76-99.
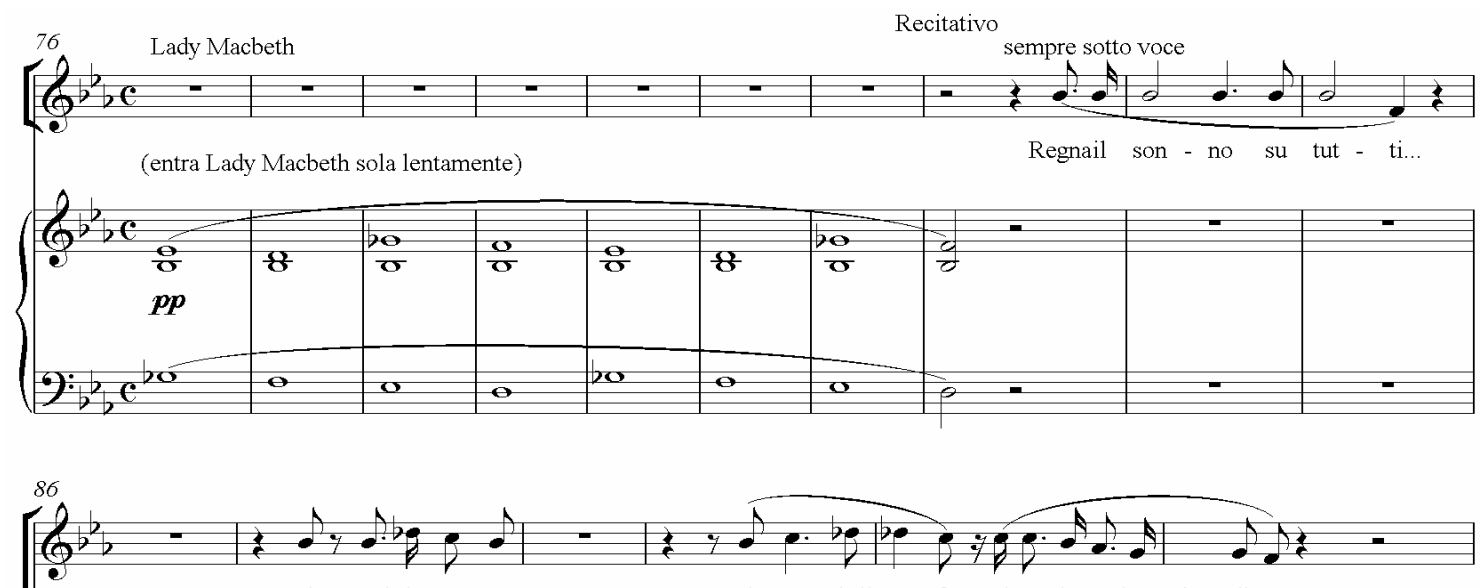

Oh, qual la-men-to! Ris-pon - de'il gu - fo alsuo lu-gu bre ad - di-o!
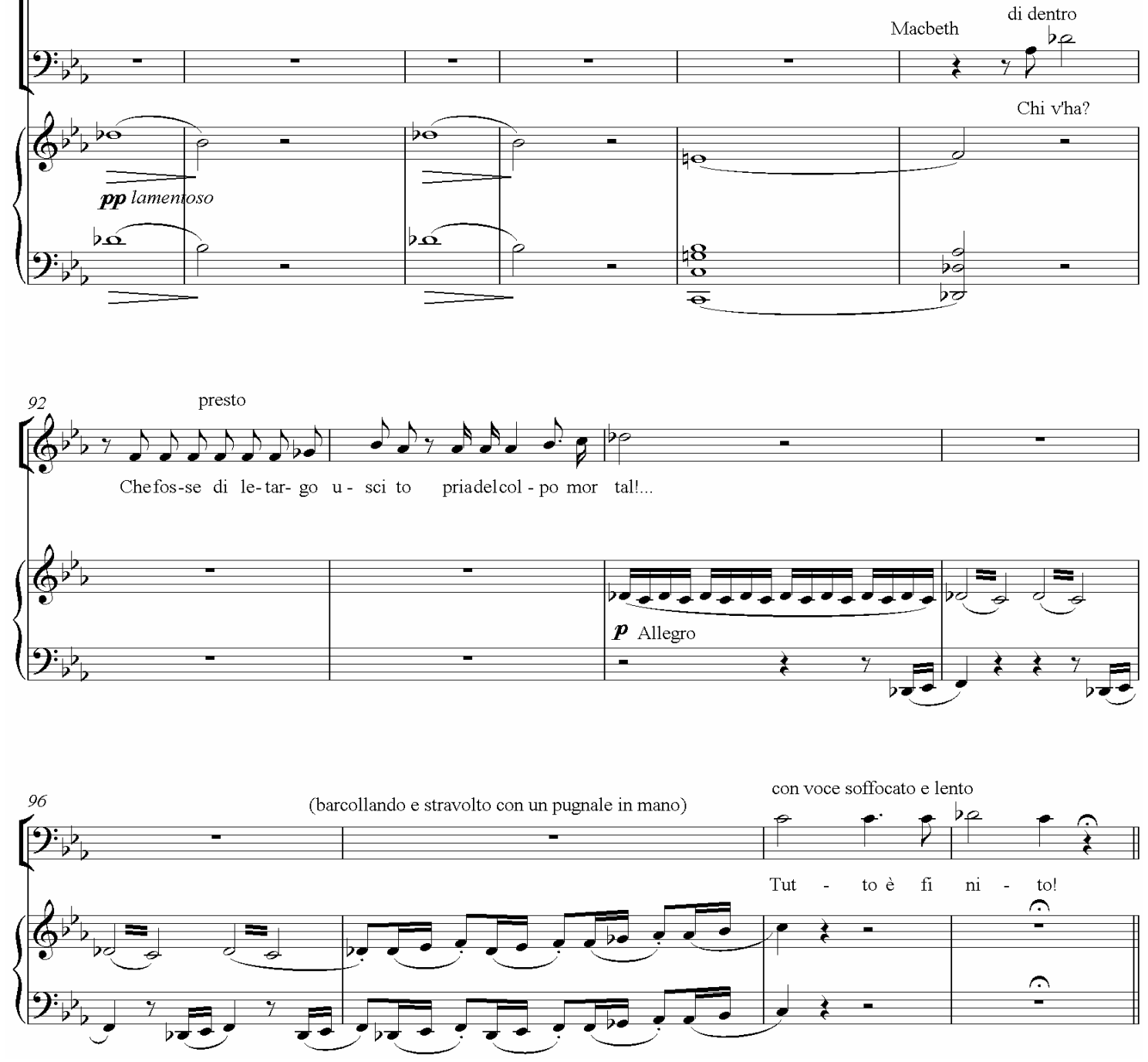
Within the male Gothic, one must leave reason outside the experience and interpretation of art. Furthermore Coleridge's 'supernatural power of the imagination' suggests that the human mind is commanding enough to provide reason within the unreasonable genres of the Gothic and the operatic. In a simplistic sense, the Gothic and the operatic become indistinguishable in Macbeth. They travel full circle, seemingly first away from each other as the Gothic subject becomes too embroiled in the macabre, and the essence of opera shifts to narratively relying on an amorous tale and dazzling vocal extravagance within a conventional structure. The Gothic and the operatic then merge for Verdi's sake of 'high' artistic intelligence. Tomlinson's example of the collision between the noumenal and phenomenal realms of the operatic sound world in Macbeth centres on Macbeth's 'Tutto é finito' motive. Although the witches are objectified in the phenomenal realm, their music is incorporated into the Macbeths' music as small motivic gestures (example 3.4). These musical examples are less distinguishable, if more wide-reaching, as they enter the noumenal realm of Macbeth's internal world. Consequently, the noumenal limit becomes less defined by being woven into the music. Therefore, the witches' music becomes an expression of the Gothic, represented by the noumenal force, that 'supernatural power of the imagination'.

The witches' motive is also operatic. It functions on a musical level as to meld the realms of all arts, in both visible and invisible ways; music, drama, art and literature all work dependently to create a form of operatic Gothicism. Tomlinson says:

... since the orchestra's recollection of earlier materials functions at a motivic level that, unlike the thematic recurrences in Lucia and La sonnambula, can defy easy definition, the orchestral voice is not heard to speak in the overt, objectifying manner of its counterpart in Lucia. Instead it comes to represent a physic force that is less tractable because it is less easily isolated, a force that limns the noumenon all the more accurately in resisting objectification. ${ }^{65}$

${ }^{65}$ Tomlinson, Metaphysical Song, Princeton: Princeton University Press, 1999, p. 96. 
In his argument, Tomlinson denies the role of the witches as a 'psychic force' in the opera, limiting this definition, and his representation of noumenal forces, to Macbeth's lament and its reincarnations: the witches do not entirely express the noumenal, but neither do the other thoughts flickering through the depths of the Macbeths' minds. By carrying out the witches' forecast, the Macbeths' feelings of guilt and an anxiety over the dread of their crimes being discovered fills their subconscious, creating feelings which go unacknowledged until they implode in a Gothic episode. It is not the witches guiding their hands to fatal deeds, but their own lust for power, which in Lady Macbeth is greater than any repulsion or horror of regicide.

Nonetheless, the witches consume the Macbeths' music to a greater extent than the lament motive - a symbolic sound of Macbeth's guilty consciousness. If libretto and music are considered together, it is evident that Macbeth's voice shares in the revealing of noumenal realms. 'Tutto é finito' is not just a noumenal abstraction, but an expression of emotion at an action, part of the long tradition - reaching right back to the earliest of operas - of musically depicting the sobs and wails of despair. The music of the witches is matched to no direct textual conception, however. It is even harder to pin down than the lament, but is consistently evoked in the tinta by an uneasy abstraction of style and mood. Tomlinson, however, only appears to notice their visual form, failing to mention their strong supernatural presence in the prelude when he consigns its thematic material to Lady Macbeth:

Against this background the rocking figure in the sleepwalking scene can only link Lady Macbeth's noumenal awareness to her husband's ['Tutto é finito' 5${ }^{\mathrm{b}} 6-5$ lament]. In doing so it connects out to the play of mysterious forces (that especially preoccupy Macbeth) across the opera as a whole. The crudely objective forms that these forces assume - the witches, ghosts, and apparitions certainly need some noumenal reaffirmation.

If we are analysing Verdi through minute motivic details, then the witches' music in the first Act is littered with descending semitone phrases; musically and narratively they are 
therefore the root of all problems. Macbeth's mournful exclamation is, nonetheless, a development of this, now more exaggerated and separated from the orchestral voice than it is earlier in the opera.

The relationship between the vocalist and their orchestral accompaniment those other voices - has implications for detecting the Gothic within a metaphysical context. Rather than the appearance of the 'numinous intruder' being confined to moments of narrative (dis)integration, the Gothic appears to lie on a plane as slippery as the witches'. The flashes of thoughts from within the psyche, particularly those of the macabre or with the effect of arousing horror, evoke the Gothic. Often brutal deeds (or the mention of them) in the libretto are supported by the orchestral voice, echoing the vocal line, as an emphatic annunciation of the subject. For the witches, this melodic emphasis renders them two-dimensional, without a perceptible subconscious, as a primordial being not endowed with the faculty for multifarious thought. A similar musical parallel is portrayed in the chorus of assassins who do not need to display a depth of character: they follow Macbeth's orders, as servants, also belonging to a class below the Macbeths. In addition, Winton Dean contends that 'had Verdi approached the play in his maturity...he would hardly have written the comic opera choruses of Witches and Murderers, which for some reason he allowed to survive the revision' ${ }^{66}$ Perhaps Dean is unfair to the witches here, for their musical and dramatic value is evident through the way their musical style or direct motives appear in the music of other characters. Verdi was able to relocate some of Shakespeare's dialogue for operatic purposes, including transposing the conversation between Macbeth and the murderers to the first two lines sung by Verdi's chorus of assassins.

\footnotetext{
${ }^{66}$ Winton Dean, 'Shakespeare in the Opera House' in Essays on Opera, Oxford: Oxford University Press, 1965, p. 245.
} 
205

Example 3.5: 'Come del ciel' from Act 2, scene 2 of Verdi’s Macbeth, bb. 21-9.
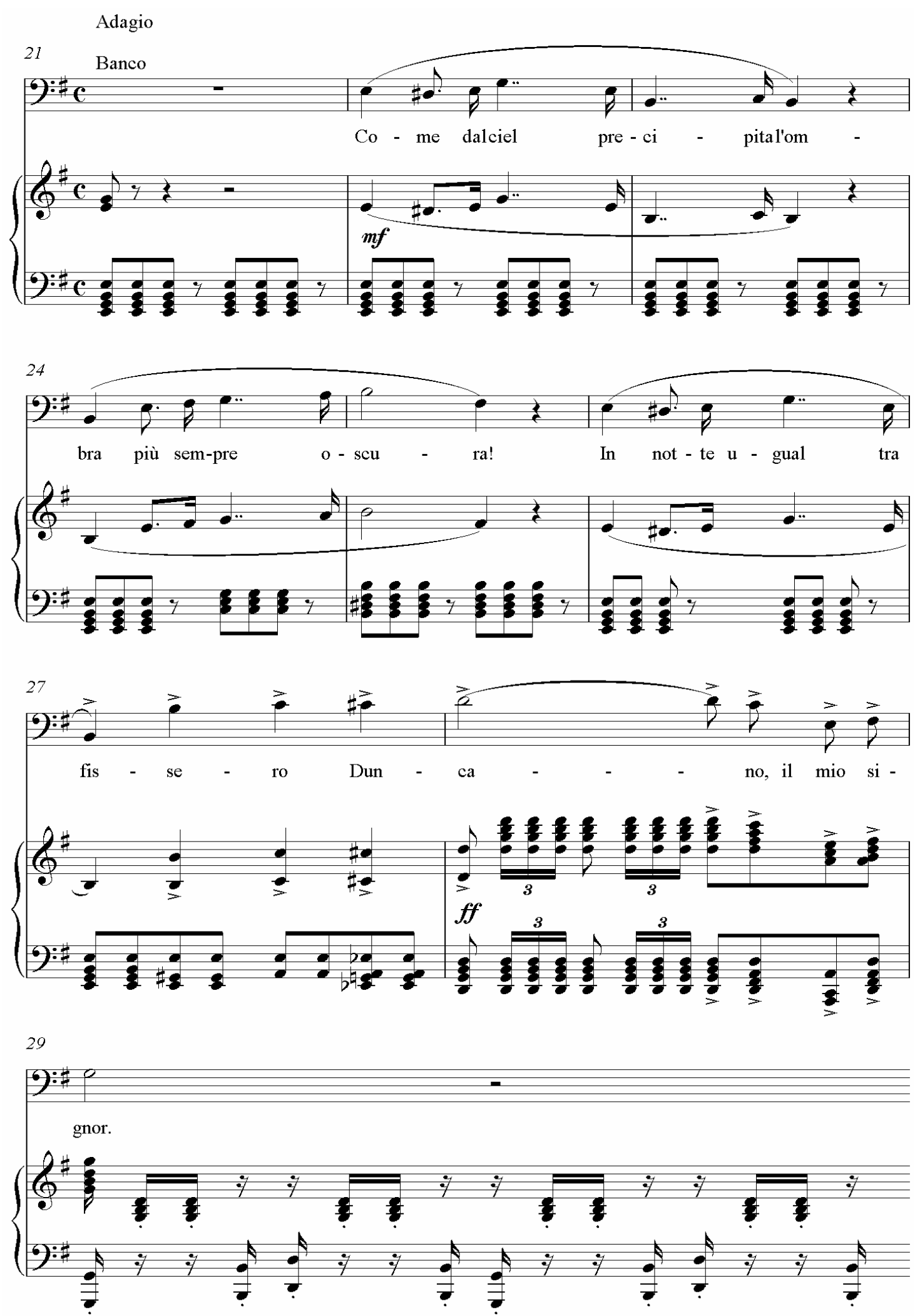
This flows directly into Banco's murder, thereby relocating Shakespeare's Act III, scene ii - the account of Banquo's imminent fate - to before the assassins are summoned. ${ }^{67}$ As well as being dramatically necessary for Verdi's opera, this change removes Macbeth from involvement in initiating the prophesy's realisation: in the play Macbeth appears to have coordinated the murder alone. He informs his wife after his discussion, telling his wife 'Be innocent of the knowledge, dearest chuck, / Till thou applaud the deed'; while in the opera, the Macbeths recognise what their next action will be almost simultaneously. ${ }^{68}$

Orchestral imitation is a noticeable musical feature again when Banco senses his impending danger in his adagio ('Come dal ciel'): there is nothing hidden from the audience about his fate here, its Gothic motive is clear (example 3.5). ${ }^{69}$ In the Act 1 duet, Macbeth's music is emulated by the orchestra, as he recollects the events to Lady Macbeth and deplores his own actions. Newly promoted and rendered impressionable by the witches' prophecies, Shakespeare's Macbeth is already lured by further power before Lady Macbeth's intentions to self-fulfil his 'destiny' are recognised. Moreover, it shows a complexity in character that is not taken to the same level in the opera

\footnotetext{
${ }^{67}$ Verdi's Act 2 begins in a chamber of Macbeth's castle, where the composer is able to relinquish the need for Shakespeare's II:iii- III:ii and their characters, extraneous for operatic purposes by interpolating them into a few lines of Lady Macbeth: Parlàr le malïarde, e re tu sei. / Il figlio di Duncàn, per l'improvvisa / Sua fuga in Inghilterra, / Parricida fu detto, e vuoto il soglio / A te lasciò. [The enchantresses spoke and now you are king. / The son of Duncan, for suddenly making / His flight to England, / Has been suspected of Patricide, and the empty throne / Is left to you.] Other changes are carefully made, and Verdi has lost as little as possible of the original play or its sentiment. Some examples would be where the text of Shakespeare's Macbeth is not uttered by the same character in Verdi's opera, for example it is not Shakespeare's Macbeth who asks what creatures the witches are, but his Banquo, or the witches return at the end of Verdi's first scene announcing they will await fate and summon their oracle at Macbeth's return has no precedent in Macbeth, unless it is considered as transposition of Shakespeare's I:i. The second scene of the opera's first Act interpolates Shakespeare's I:v - vi and II:i-ii. Duncan's arrival in I:vi uses none of Shakespeare's text, but is musically and mimetically rendered by Verdi with the royal procession, therefore also removing the need for the King to have a vocal role. Additionally, the opening of scene 2, an exchange between Banquo, Fleance and Macbeth is cut, as is the porter's scene directly following the murder, replaced by the chorus's first appearance.

${ }_{68}^{68}$ Shakespeare, Macbeth, p. 980, 11. 46-7.

${ }^{69}$ Orchestral mimesis is a common musical technique in choruses, yet this enforces the notion that it is representing a distinctly explicit idea.
} 
because of the focus on Lady Macbeth. Verdi has excised this scene (Shakespeare's I.

iv.), including Macbeth's aside that: ${ }^{70}$

The Prince of Cumberland - that is a step

On which I must fall down or else o'erleap

For in my way it lies. Stars, hide your fires, Let not light see my black and deep desires;

The eye wink at the hand; yet let that be

Which the eye fears, when it is done, to see. ${ }^{71}$

In Shakespeare's original, Macbeth does not automatically follow his wife's lead. He contemplates his and his wife's actions further and announces: 'We will proceed no further in this business: / He hath honour'd me of late; and I have bought / Golden opinions from all sorts of people' ${ }^{72}$ Macbeth is now decisively opposed to disturbing the social order and able to refuse the earlier temptation to cause his own succession. This is cursory bravado, and all it takes to sway Macbeth back to Lady Macbeth's path of corrupt and purely selfish aggrandisement is her deriding him as a coward. In the opera, Macbeth lacks an obvious crisis of conscience or the boldness to object to the murderous plan in the first instance, despite the fear of failure and remorse it instils in him. Indeed, it is implied in the libretto that Macbeth has foreseen Duncan's death as the path to his success when he confirms he understands his wife's intentions:

Lady Macbeth: Mai non ci rechi il sole un tal domani.

Macbeth: Che parli?

Lady Macbeth: E non intendi?

Macbeth: Intendo, intendo!

Lady Macbeth: Or bene?

Macbeth: E se fallisse il colpo?

[Lady Macbeth: May the sun never bring us such a tomorrow.

Macbeth: What do you speak of?

Lady Macbeth: Do you not understand?

Macbeth: I understand, I understand!

Lady Macbeth: Well?

\footnotetext{
${ }^{70}$ This scene is an exchange between the King and his thanes, of which all bar Macbeth, Banquo, Macduff and Malcolm do not feature in the opera

${ }^{71}$ Shakespeare, Macbeth, p. 974, 11. 48-53.

${ }^{72}$ Ibid, p. 975, 11. 31-3.
} 
Macbeth: And if the blow should fail?]

Macbeth's cowardice moves to the forefront after both Shakespeare's and Verdi's famous scene of hallucination. Horrified, he betrays a single-minded guilt, something that is not recognised as clearly in Lady Macbeth. Strings and low winds echo the shape of Macbeth's melodic line or further evoke his distress by annunciating rhythmic gestures seen earlier in the witches' music. When Lady Macbeth responds to Macbeth, it is with an altered version of his vocal melody. She asks him 'Ma, dimmi, altra voce non parti d'udire?' ['but, tell me, did you not hear another voice?'] and her words, unlike those of Macbeth's, are mirrored by the orchestra. Any internal-external voices are united in this passage, but at the same time Lady Macbeth is scornful, mocking the 'voices' Macbeth has just heard addressing him by his various titles. Thus at the same time, the phrase illustrates Lady Macbeth's unfaltering mind - she is already sure that the light of day (and later a drop of water) will absolve their crime. She utters, seemingly to herself as well as Macbeth 'Follie, follie che sperdono / I primi rai del dì' ['Madness, madness that vanquishes / In the first light of day']. However, when she sings from 'Sei vano, o Macbetto' [you are conceited, Macbeth], punctuated by a witchassociated motive in the clarinet, her lines are separated from the orchestra (example 3.6). Also from this line, Lady Macbeth echoes Macbeth's musical language, which could imply either that she does recognise something of Macbeth's guilt, or perhaps more likely, that she is easily able to adapt to his musical language in order to persuade him to suppress his agitation after accomplishing their brutal deed.

This fluctuation between the representation of internal and external thought shows the jumbled minds of the Macbeths at this stage and Verdi uses dissected orchestral parts to signify the psychic tumult in scenes of Gothic intrusion. 
Example 3.6: duet in Act 1, scene 4 of Verdi's Macbeth, bb. 136-94.
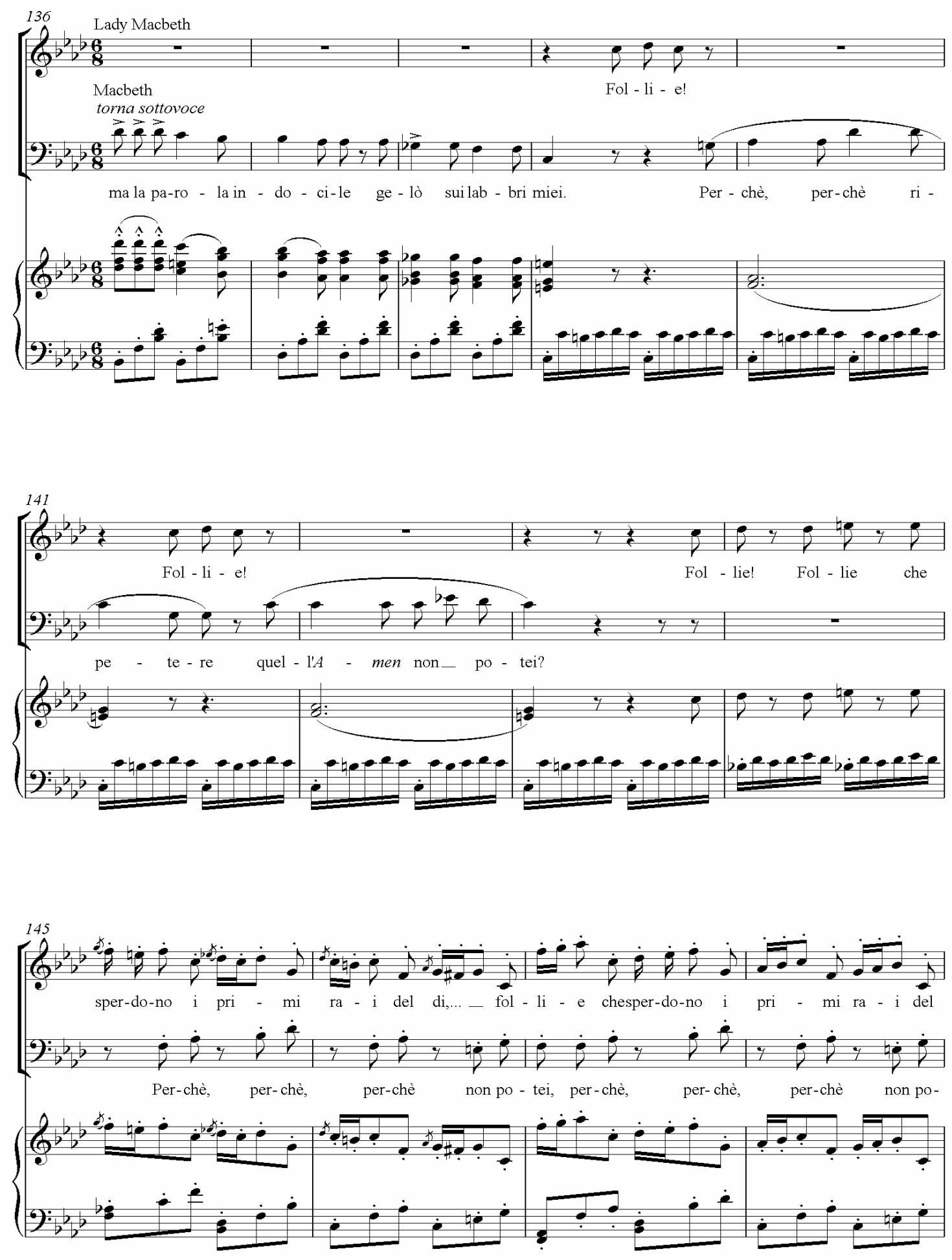

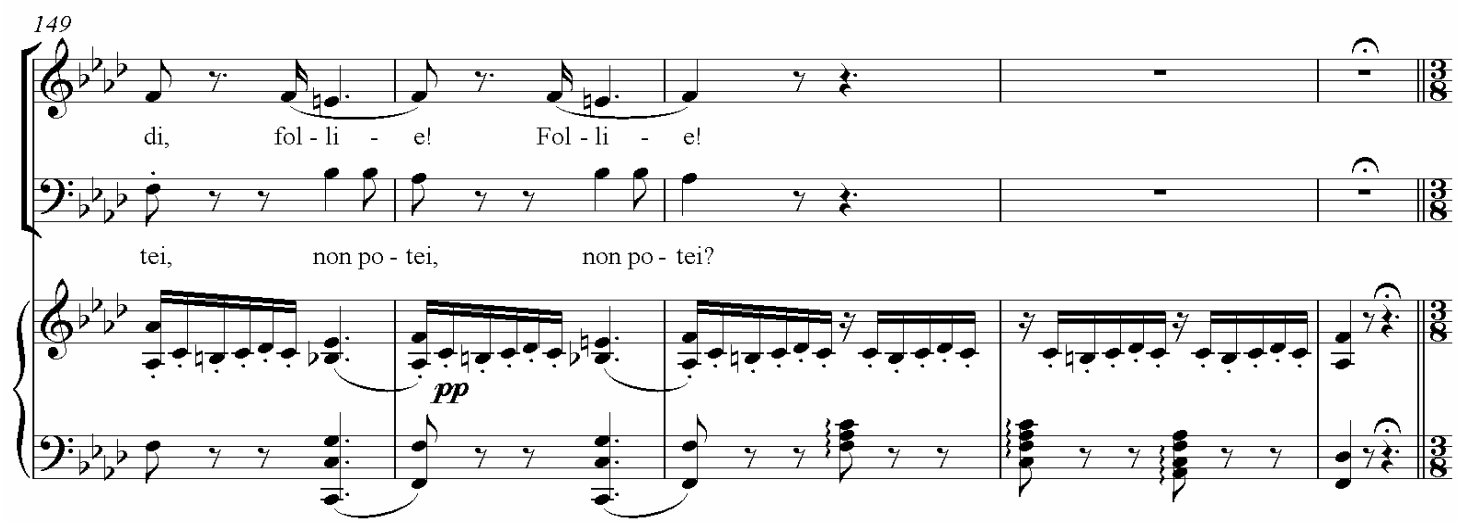

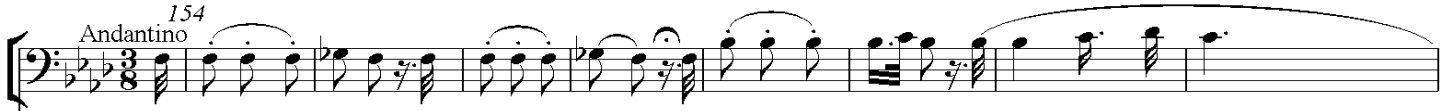
Al - lor que-sta vo-ce m'in - te-si nel pet-to: a vraiper guan - cia li sol ve - pri, oMac-bet

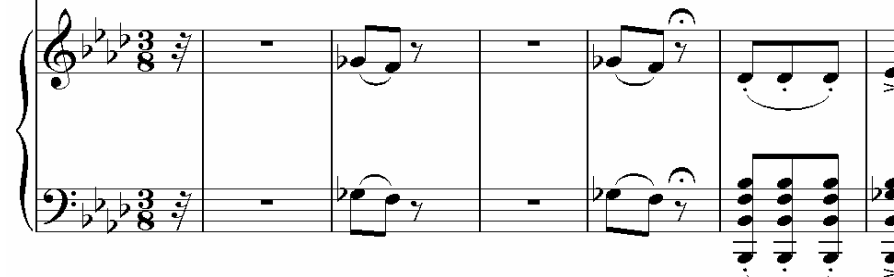

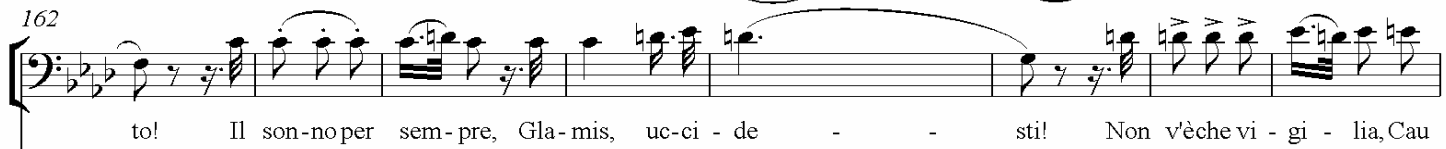
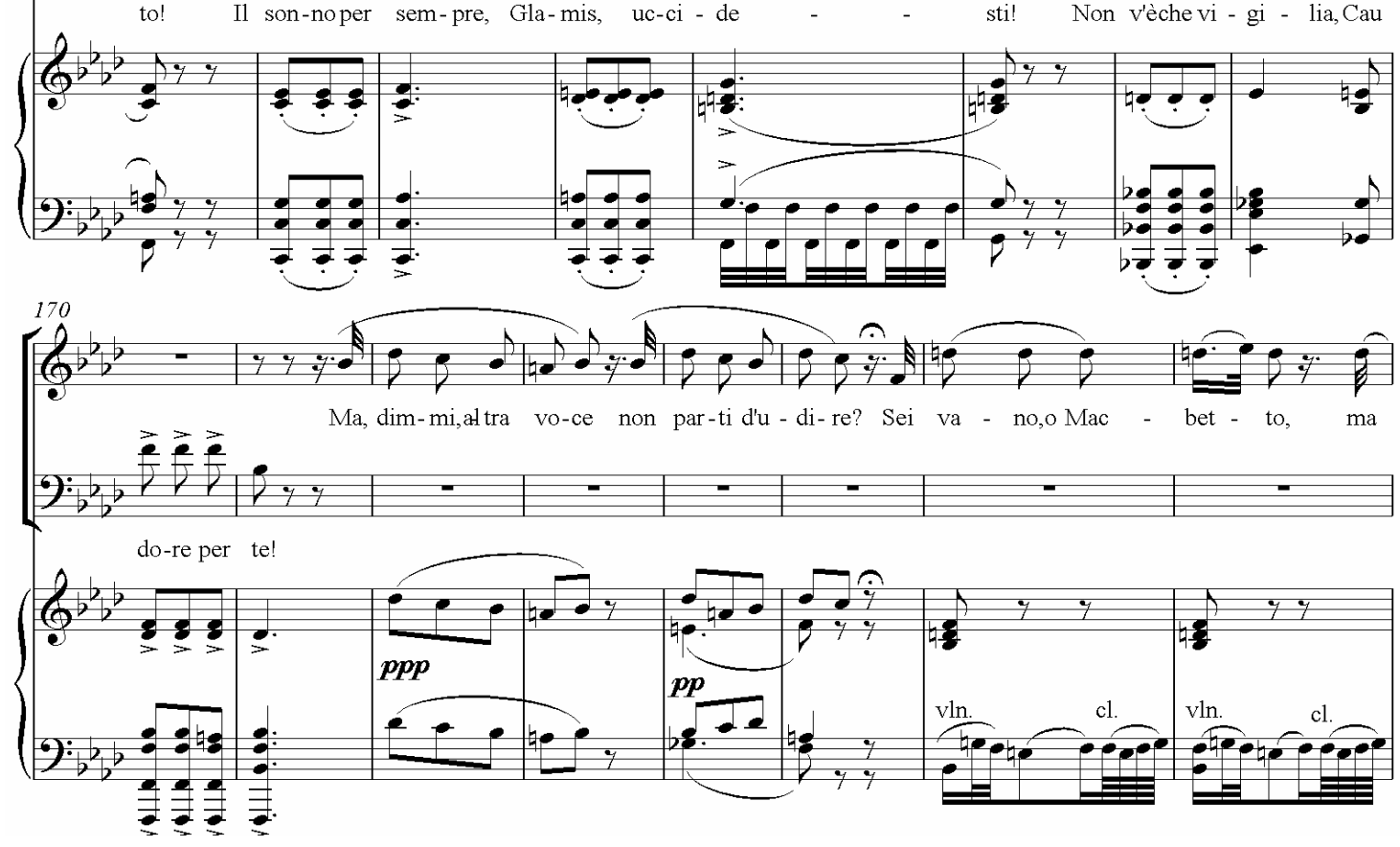

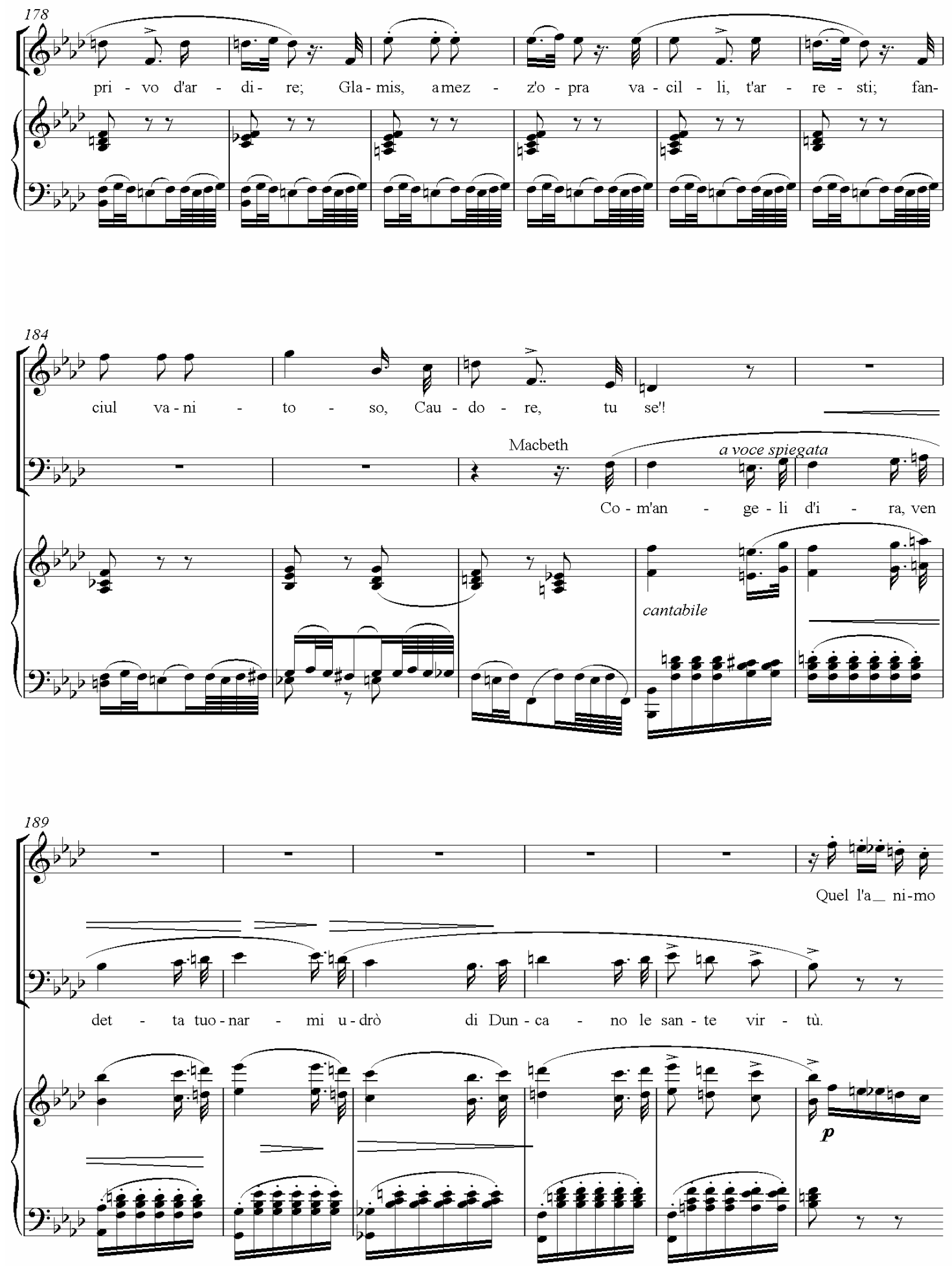
These scenes always occur at noumenal-phenomenal junctions, for in periods of heightened emotion the characters are deaf to the projections of their own voices, even if they remain acutely aware of phenomenal sound. The Act 1 duet is the most prominent example of this - one of the scenes Verdi saw as pivotal to the opera's success. Elizabeth Hudson explains the shift between figurative and 'real' sound and how the Macbeths respond to the changes in the projected sound world. The sound realm 'move[s] from imagined sound and action in the opening section of the duet, to actual sound and irreversible deed. ${ }^{73}$ Here, it is not a direct interruption by an external force visible to the audience, but rather an indirect association showing the power of the imagination, in which the subconscious emerges into an audible sound world of the opera. Macbeth's footsteps are the only sound with a visible parallel; the knocking and other extraneous sounds become bodiless, yet audible, conceptions, and Lady Macbeth is only able to speculate that the sounds they hear in their jittery states are an owl or each other. Moreover, the 'collision of the external worlds' represented in this sequence is different for the audience, who can see the cause of the sounds no more than the Macbeths can. Thus this confusion of internal and external sounds is significant in revealing the oscillating noumenal limits for Macbeth, Lady Macbeth, and the audience. $^{74}$ The scene also presents a similar incorporeal quandary to that experienced by most of the characters in the opera during Banco's ghostly materialisation in the next Act, which Macbeth alone can see despite Banco's on-stage presence.

\footnotetext{
${ }^{73}$ Hudson, "'...qualche cosa d'incredibile...": Hearing the invisible in Macbeth', Cambridge Opera Journal, Vol. 14, No. 1 (March, 2002), p. 29.

${ }^{74}$ Ibid, p. 14.
} 
Example 3.7: 'Sappia la sposa mia', Act 1, scene 4 of Verdi’s Macbeth, bb. 9-22.
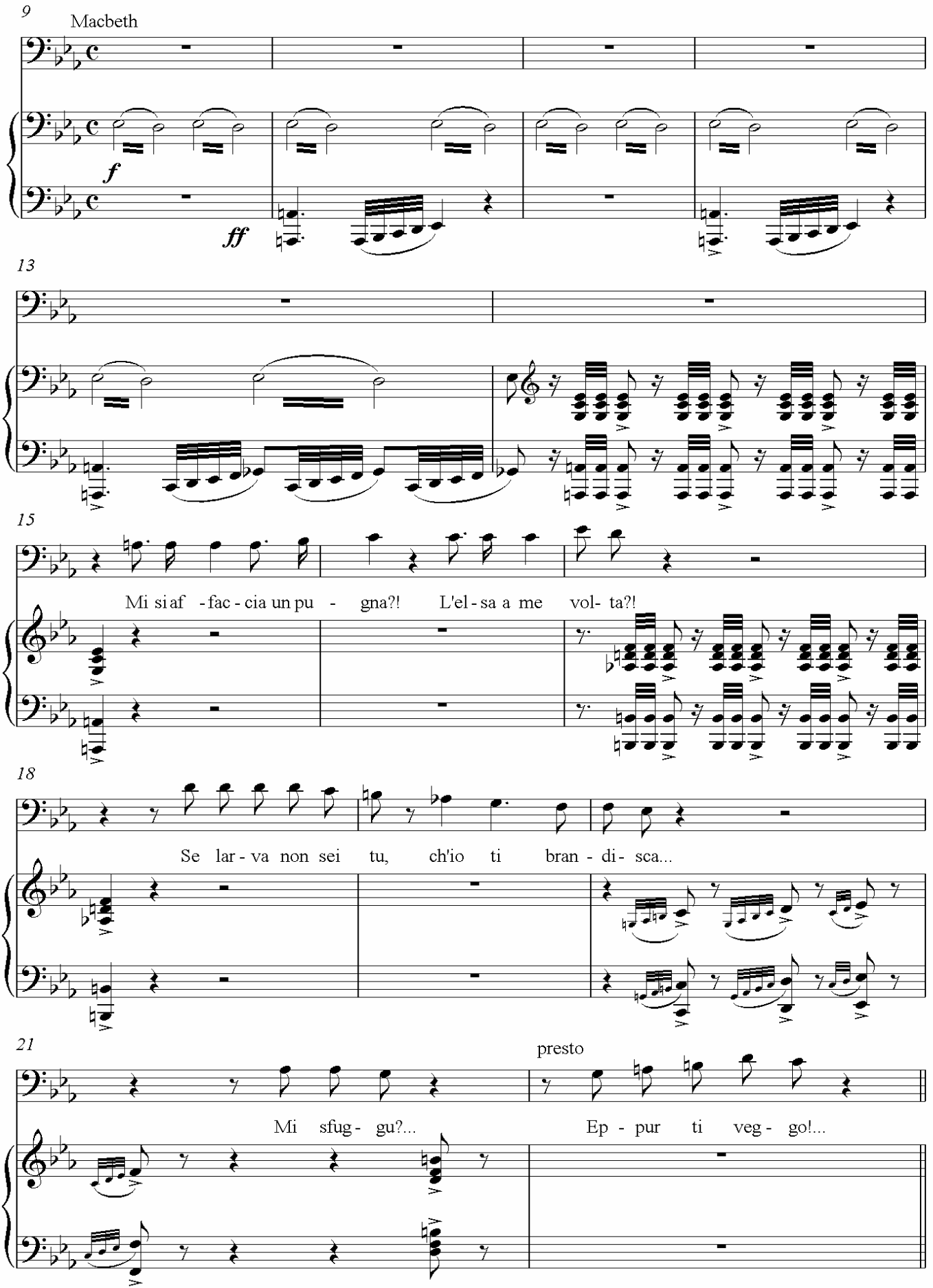
The inexplicable nature of sounds and visions in Macbeth prompt an affiliation with the male Gothic, as their source lies within the psyche and the opera's sound world. But these sounds and visions have no material form or justification. ${ }^{75}$ The apparitions are generated from an external underworld, but channelled through the corporeal existence of the witches. The other instances of Gothic intrusions are Macbeth's earlier hallucination of the dagger and his vision of Banco's ghost. The dagger scene recalls Lucia's cavatina - her vision of the phantom at the fountain - as the audience only experiences Macbeth's vision through sound.

Example 3.8: The witches are mentioned in the text and musically illustrated in 'Sappia la sposa mia', Act 1, scene 4 of Verdi's Macbeth, bb. 52-6.

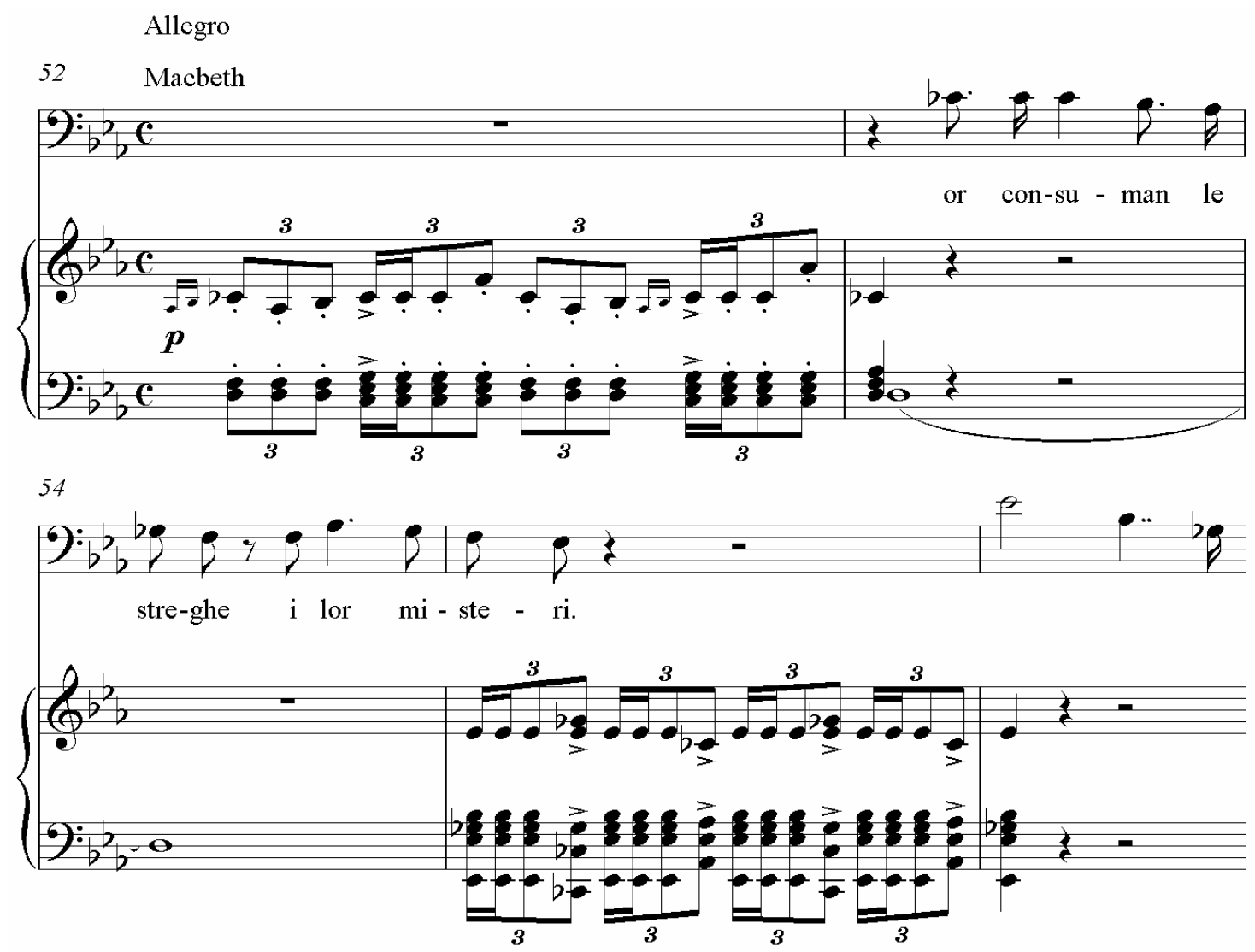

\footnotetext{
${ }^{75}$ In Shakespeare the knocking alone is reasonably explained by the porter, effectively rendering their distress comical.
} 
As the whole episode occurs within the scena, it is tonally and motivically fragmented, depicting images flickering through Macbeth's mind. The music, especially the rhythmical strings, is evocative of the witches' entrance, and he summons the creatures' triplet motive when he refers to them in the text in a moment of musical lucidity (examples 3.7 and 3.8).

In his opera Verdi (unlike Shakespeare) gave the scene following Banco's murder to Lady Macbeth. Her exclamations in 1847 are triumphant, conveying a more preemptive success than seems appropriate even for such as malicious character:

Trionfai! Securi alfine premerem di Scozia il trono. Or disfido il lampo, il tuono le sue basi a rovesciar, a rovesciar. Tra misfatti l'opra ha fine se un misfatto le fu culla, la regal corona è nulla sepuò in capo vacillar!

[I triumphed! Ingress at last I may bear down upon the throne of Scotland Now I defy the lightening, The thunder of its elements Overturn, topple,

Among crimes the deed has ended

If a crime was a cradle

The royal crown is nothing

if it is able to wobble atop the head.]

Verdi revised Lady Macbeth's original aria as 'La luce langue' for 1865 . Her words a less defiantly triumphant, but Verdi still tints her lyrics with an intense desire for the throne:

La luce langue, il faro spegnesi ch'eterno corre per gli ampi cieli! Notte desiata provvida veli la man colpevole che ferirà. Nuovo delitto! E' necessario! Compiersi debbe l'opra fatale. Ai trapassati regnar non cale; a loro un requiem, l'eternità. 
O voluttà del soglio!
O scettro, alfin sei mio!
Ogni mortal desio
tace e s'acqueta in te.
Cadrà fra poco esanime
chi fu predetto re.

[The light is languishing, it has been snuffed out, that which eternally crosses the wide sky.

Awaited night, throw a veil

over the guilty murderous hand.

A new crime! It must be so!

The fatal deed must be performed.

Power means nothing to the dead;

for them a requiem and eternity.

Oh, desire of the throne!

Oh, sceptre, at last you are mine!

Every mortal desire

is quieted and calmed in you.

He will soon fall lifeless

who was prophesied king.]

The revisions Verdi made to Lady's Macbeth's music changes her characterisation in the Paris version. There are disruptions to the lyric form of her original aria, 'Trionfai! Securi alfine', but in 'La luce langue', Verdi alters Lady Macbeth's character extensively. The audience are pulled into her more complex character, who comes to make a decision about the next step she and Macbeth must take to secure the throne and realise the witches' prophesy, rather than being resolved from the outset. This could, in turn, suggest why the duet and sleepwalking scene didn't make as great an impact in Paris; set against 'La luce langue' instead of the earlier 'Trionfai! Securi alfine', Lady Macbeth's other significant numbers do not represent as radical a transformation of her character. A sense of the Gothic mood lies in the horrifyingly unrepentant and bloodthirsty determination of her original 1847 aria, but the adaptation for Paris gives Lady Macbeth a more realistic psychological depth and balances her character in this way with Macbeth, who portrays his uncertainty at their actions and his later his guilt. Furthermore, Lady Macbeth's 'La luce langue' is a point where Verdi's dramatic 
developments between Donizetti's Gothic opera and his own earlier version of Macbeth are evident.

While the witches, and Lady Macbeth's response to their prophecies, drive the plot, they also insinuate the important position of the heroine above all - and women more generally if the witches, bearded though they may be, are included. Lady Macbeth is the more ambitious and malignant of the two Macbeths, especially when carrying out Duncan's murder. She pushes him to ensure the predictions are fulfilled then finishes the actions herself (returning to the scene of the crime to implicate the men in the King's chamber by smearing them with blood) when Macbeth is unable to execute them. These actions do, however, come at a price. Lady Macbeth's guilt, although slower to take hold than Macbeth's own does eventually manifest in her sleepwalking scene. Her role is magnified to the extent that she overshadows her husband in Verdi's opera, far exceeding her role in Shakespeare's play (just as in Lucia, Donizetti extended Lucia's mad scene from the three paragraphs Scott dedicates to her insanity after she has stabbed Arthur).

In her brindisi, her aggrandising toast as queen, Lady Macbeth declares that life is for pleasure, a sentiment which for her guests, unaware of her crimes would initially seem innocuous enough. However, by the end of the scene the audience appears to suspect the Macbeths' guilt and is disturbed by Macbeth's hallucination. From the outset, Lady Macbeth's proclamations are chilling for an audience who is privy to the Macbeths' foul exploits. The libretto suggests her fantasy that they are untouchable and that there will be no repercussion for their deeds. Lady Macbeth even seems to believe it is possible for an absolution of sorts, or perhaps is trying to persuade herself of this, as she sings that life is for pleasure. By attaining power they are thus achieving pleasure:

Da noi s'involino

Gli odi e gli sdegni, 


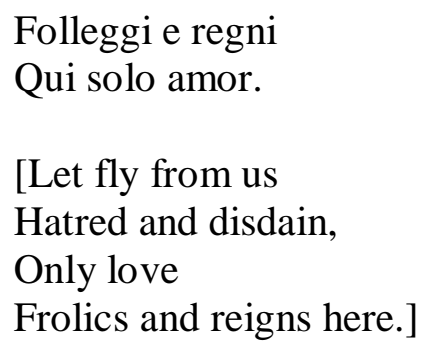

The triviality of the brindisi, at least at its beginning, sits uneasily within its Gothic context as a reprise from the fantastic and the horrifying. The scene is inserted between instances of brutality and the other-worldly, even though Verdi felt that 'a short respite after all the preceding turmoil will do no harm'. ${ }^{76}$ Moreover, the brindisi has a precedent in Shakespeare's Macbeth as a moment where the tragic and comic are contrasted as a matter of course, each to underscore the other. With Shakespeare's other comic moments removed, such as the scene with the porter, in the Act 2 finale, Verdi emphasises this Romantic juxtaposition that Hugo outlines in his preface to Cromwell. Verdi's scene is tragic when the assassin gives Macbeth the news of Banco's death, and at the subsequent appearance of Banco's ghost and Macbeth's disturbed reaction. Yet the finale is also comic as Lady Macbeth performs her lively toast, and because chorus cannot see the ghost despite its physical presence on stage. Verdi's comic reprises, however, is short-lived. ${ }^{77}$ The second Act finale becomes a Gothic climax in both the opera and the play, where Macbeth's heady dose of guilt fells him. His Gothic state, introspective and psychologically disturbed, is given dramatic force when it is contrasted with the festive, public musical atmosphere. Macbeth is concerned with his realm of imagination and the 'reality' of Banco's ghost, but at the same time, Lady Macbeth and the guests are celebrating, aware of their melodic voices and musical

\footnotetext{
${ }^{76}$ For the second Macbeth, Escudier urged Verdi to allow a 'little modification' in the brindisi, giving a larger role to the tenor (Macduff), a move not unexpected when Parisian audiences were accustomed to a tenor lead. Verdi insisted that Lady Macbeth must remain the 'dominant musical character dramatically as well as musically' See the letter of 28 March 1865; Rosen and Porter, Sourcebook, p. 115.

${ }^{77}$ Both the first verse of the brindisi and the royal procession of Verdi's Act 1 in which the music displays a trivial banda quality and there are no words could be considered interludes, poised to make the scenes after them (Duncan's murder and the appearance of Banco's ghost) all the more terrifying.
} 
experience. The brindisi is phenomenal, and it is perhaps the phenomenal environment of the scene which gives the noumenal intrusion more impact. ${ }^{78}$

In the Act 2 finale Banco's ghost appears as the singer creating his role, shrouded or with additional pale makeup and with gashes across his throat. Verdi stipulated that he come through a trapdoor from underground. ${ }^{79}$ Despite this ghost's representation as a physical on-stage presence, the chorus is both blind and deaf to it. Macbeth questions whether his wife can see the contrite figure; she cannot, but she can easily deduce what Macbeth is envisaging. The musical characterisation of Macbeth's uncanny experience is underpinned by a major-minor shift from F-f and a semitone interval of $C-D^{b}$, which inverts the ${ }^{b} 6-5$ lament, (or gives the first third of the $5-{ }^{b} 6-5$ 'Tutto é finito' motive). The ascending diminished fourth exposed in the clarinets and bassoons elicits a rising terror in both Macbeth and his on-stage audience, not too distant from the discomfort the lament gave Lady Macbeth in the duet (example 3.9).

Example 3.9: Brindisi theme, Act 2, Verdi's Macbeth, bb. 80-8.

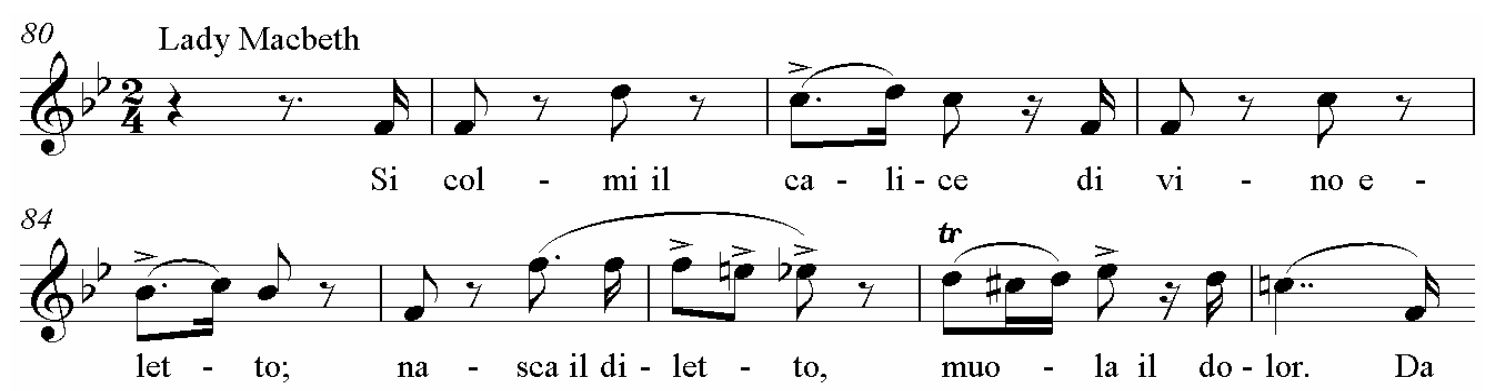

The second bar of the two-bar brindisi theme also pre-empts the Gothic intrusion, as a transference of the 'Tutto é finito' gesture that becomes imbedded in the operatic sound

\footnotetext{
${ }^{78}$ Verdi also uses the context of a public musical setting to emphasise Violetta's inner torment in $\mathrm{La}$ Traviata and Gilda's realises the Duke's true character as she watches him pursuing Maddalena through the tarvern window in Rigoletto.

${ }^{79}$ Marcello Conati, 'Aspects of the Production of Macbeth' in Rosen and Porter, Sourcebook, p. 234.
} 
world. The theme mutates into a celebratory toast by Lady Macbeth and is blindly taken up by the chorus. In this respect, the motive becomes as pervasive as the witches' rhythmical characteristics.

Macbeth's developing mania is quelled by Lady Macbeth, who reprimands him, afraid their crimes will be discovered: 'Voi siete demente! ... Sedete, o mio sposo! Ogni ospite è tristo. / Svegliate la gioia!' ['You are insane! ... Sit down, husband! Every guest is downcast. / Awaken the joy!']. She manages to calm him briefly, and reprises her toast, but her cadence is cut short by Macbeth's cry of 'Va!' ['Go!'] As he encounters the ghost once more and is unable to control his actions as the madness trounces him (example 3.10). When the witches show him the procession of future kings, Macbeth becomes volatile in his unstable mental state, attacking the phantoms in a resurgence of lunacy and his behaviour stirs the chorus' suspicion. Banco's ghost is not 'real' to anyone other than Macbeth, although it is standing amongst the guests on stage; this effectively intensifies Macbeth's dissolving reality. The witches appear once more, textually and musically, as Macbeth makes a rash decision to seek them out, surely under the impression they may finish the chaos they inaugurated. An obsessive semiquaver pattern in the strings, taken from the third round of the witches' allegro, reappears immediately at the interruption, forcing the Gothic convolution of Macbeth, the witches and the supernatural. The witches overflow from Macbeth's subconscious, first into his vocal line, as his triplet rhythm announces the witches in the libretto, then into the chorus and orchestra two bars later, all now in triplets accompanied by rapid sextuplets in the horns and strings. 
Example 3.10: Act 2 finale of Verdi's Macbeth, bb. 396-413.

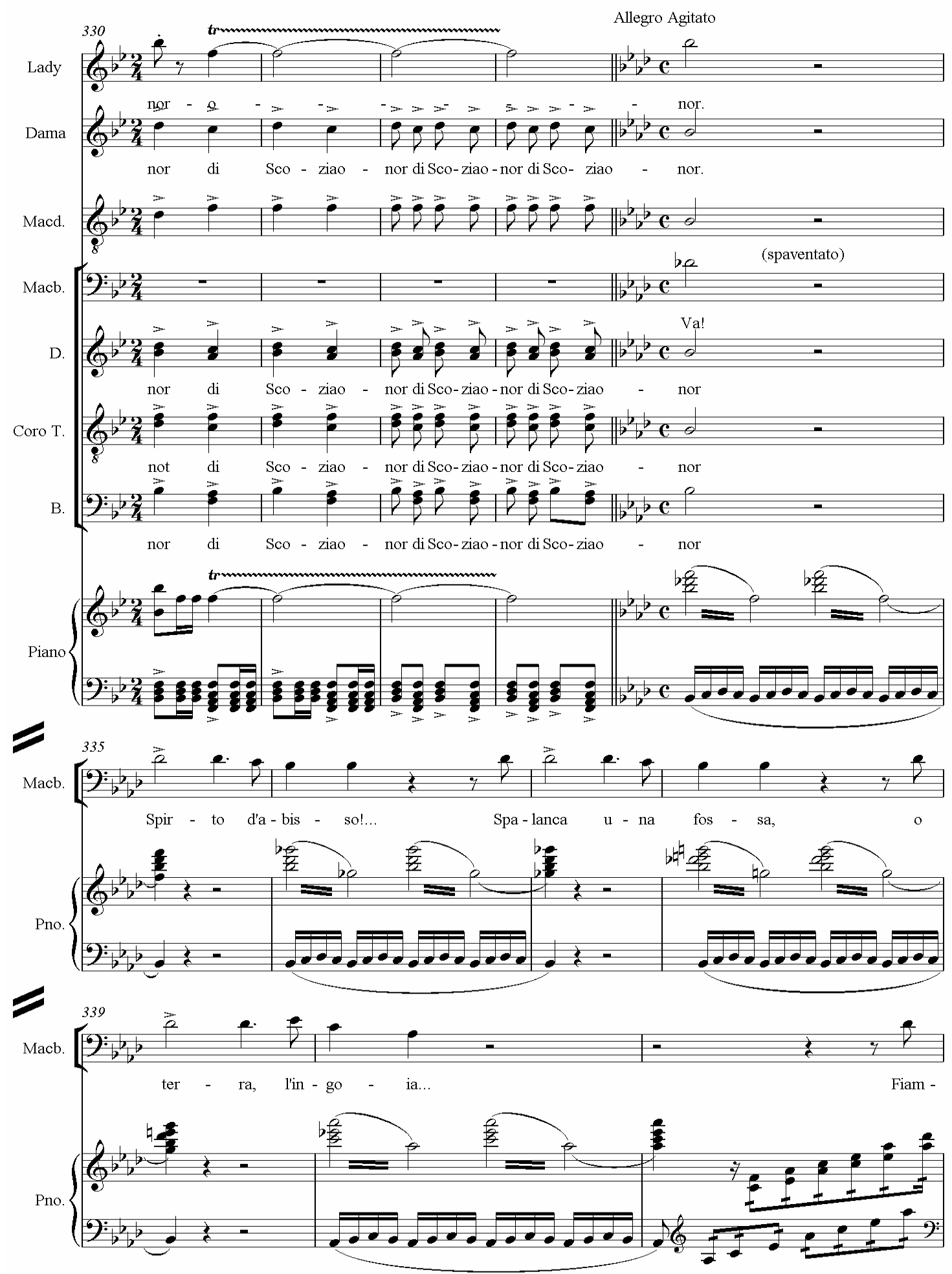




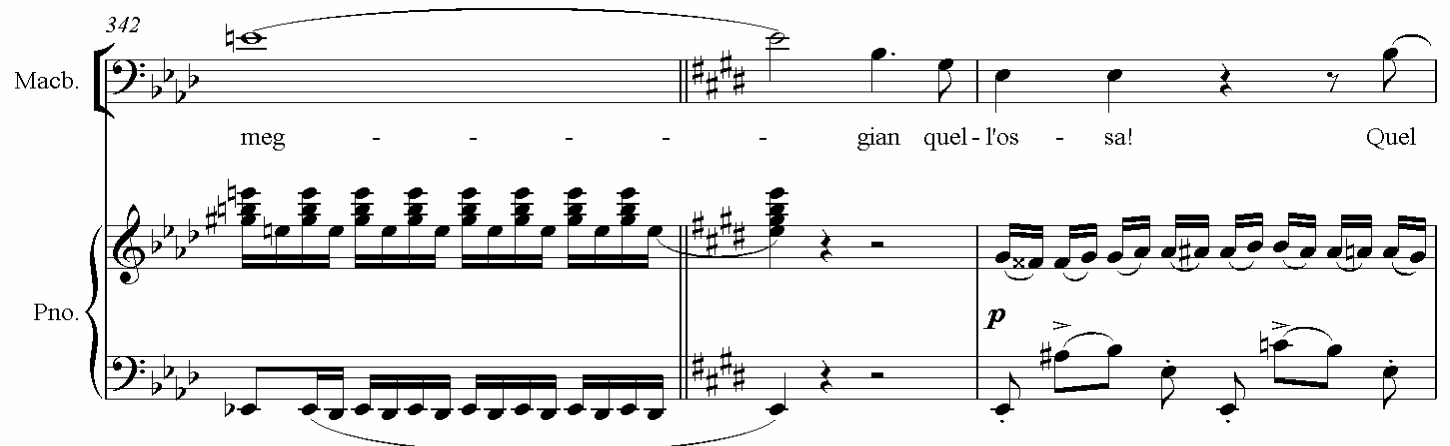

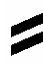

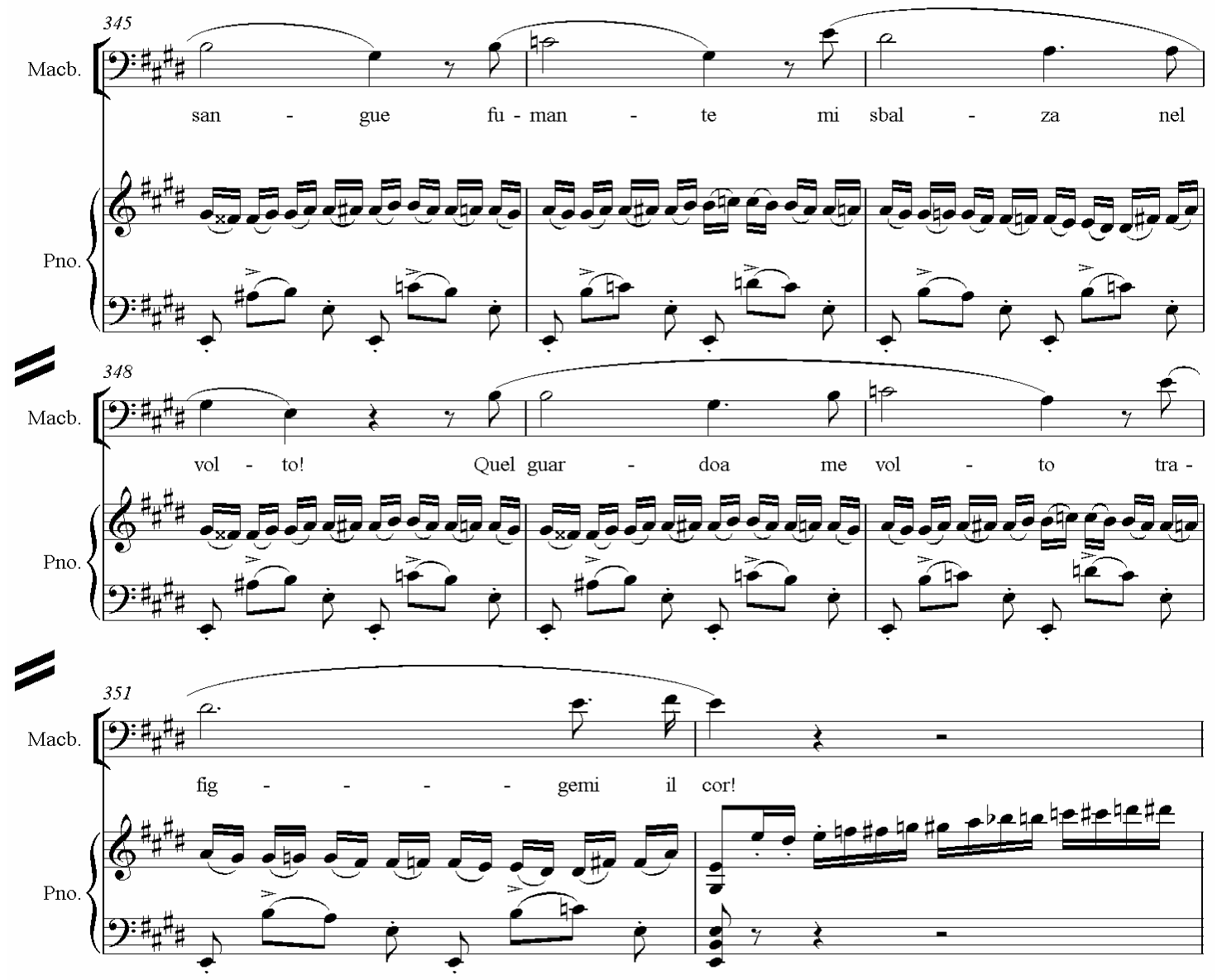


Lady Macbeth is the last to conform to this turbulent and increasingly uncanny waltz. Escape from the witches' musical dominance only comes with the end of the Act. By the end of the third Act, Macbeth has regained his 'old courage' [corragio antico] and, following Lady Macbeth's assertion earlier that inflicting death is the only answer to securing the throne and assuming power of Scotland, he decides to heed the witches' warning to beware of Macduff. For the first time, Macbeth does not hesitate in agreeing with his wife, who responds to the news: 'Menzogna! / Morte e sterminio sull'iniqua razza!' [A lie! / Death and extermination to that iniquitous progeny!] Macbeth answers 'Sì morte! Di Macduffo arda la rocca! / Perano moglie e prole!' [Yes, death! Macduff's fortress must burn! / His wife and children must perish!] Together, they sing 'L'impresa compiere deve il delitto / Poiché col sangue si inaugurò.' ['This venture must be completed with crime / since it was commenced with blood.'] And for this brief episode, it appears as if Macbeth has recovered himself after his visions of Banco's ghost, propelled by his most recent encounter with the Weird Sisters. This may be a particular feature of male madness - it kills the women.

Elaine Showalter describes insanity as a 'female malady', but according to Mary Ann Smart men are also unable to redeem themselves from the grasp of madness without dying. Smart gives evidence that not only has there historically been as many mad men in opera as there are mad women, but also that there is a multiplicity of ways in which it is expressed. ${ }^{80}$ Macbeth's vocal type makes him predisposed to insanity, which is exhibited by fewer tenors because the types of characters to descend into madness are generally fathers or abandoned lovers - secondary roles, rather than the

\footnotetext{
${ }^{80}$ Mary Ann Smart, Dalla Tombe Uscita: Representations of Madness in Nineteenth-Century Italian Opera, Ph. D., Cornell University, 1994, pp. 197 and 220.
} 
tenor hero - provoked by guilt, shame or jealousy. ${ }^{81}$ However, to some degree, this means that the main focus is still on the soprano, as it is the lead character that succumbs to hysteria, not a secondary male character. Smart explains that:

To move from the metaphorical to the concrete, however, male madness does exist in opera, and of course achieve audible expression. And when it erupts into music, it may take on a more threatening, subversive language. In other words, the general profile of the madman might reveal an expressive idiom more fundamentally disrupted than that of their female counterparts. Physical raging, translated into fragmented declamation and mercurial changes of tempo and mood, perhaps take the place of feminine coloratura excesses; such scenes are ideally suited to an operatic depiction in which the derangement provides an excuse for formal disruption or other innovations...outbursts of racing madness are actually better suited to (and tend to be confined to) the scena section of a double aria structure. ${ }^{82}$

Verdi is obviously building on at least some of the (sometimes opposing) signifiers of male madness in his portrayal of Macbeth. ${ }^{83}$ What is increasingly indicated is the use of the 'Tutto é finito' lament as a fragment of manifested madness. It occurs within the scena of the earlier duet and the Gothic baggage amassed from its first detection continues to snowball throughout the opera as madness is affixed to it.

The portrayal of Macbeth's madness also carries implications for Lady Macbeth's 'mad scene'. It masculinises it, strips it of anything conventionally feminine such as coloratura or some structured form of aria. Her mental collapse is not the raving display of Lucia. It is ridden with guilt, a precursor of male lunacy, and she falls into the pattern of fragmented declamation, idiosyncratic of Macbeth, that Smart outlines. Furthermore, Lady Macbeth's cold-blooded actions belie her gender. She resembles Lucrezia in this way, as she too employs abhorrent and sycophantic tactics to attain her desires and ends with a guilty conscience. The power play carried through much of the

\footnotetext{
${ }^{81}$ Although it is probably more accidental than deliberate, as Donizetti and Verdi were both limited by singer availability; Ibid, p. 211.

${ }^{82}$ Smart, Dalla Tombe Uscita, p. 210.

${ }^{83}$ The feminisation of the male character to represent madness was another method - one in which using the higher tenor voice is more fitting.
} 
opera between Macbeth and Lady Macbeth is telling of her status as oppressor. While earlier representations of the Gothic in both literature and opera position the women as a victim of circumstance (albeit a victim with a range of expressive powers), Lady Macbeth is a victim only of herself within the operatic diegesis. Yet it is Verdi's musical setting which exacerbates the unpleasantness of her character, and traps her in this role.

Lady Macbeth's demonic lucidity of her Act 2 aria is not to last. Her final entrance onto the stage it is in a state of sonnambulismo, as she wanders into the waiting gaze of her nurse and the doctor, who has been summoned to witness the recurring malady. Unlike in her conscious state, Lady Macbeth cannot control her actions or the vocal utterances of her mind in sleep. Lady Macbeth herself appears to see sleep as a refuge from the guilt and horror of the crimes she has committed:

A letto, a letto...

Sfar non puoi la cosa fatta...

Batte alcuno! ....andiam, Macbetto,

Non t'accusi il tuo pallor.

[To bed, to bed ...

What has been done cannot be undone.

Someone is knocking! Let us go, Macbeth,

Do not let your pallor accuse you.]

Lady Macbeth's soliloquy reveals her true thoughts: she believes not only that it is more likely for her husband be the one to reveal their guilt - he who has shown himself already susceptible to tricks of the mind and hallucinations, but also that her compunction consumes her, and her thoughts in sleep reflect those of her wakefulness.

There are no murderous daggers appearing here, and while in earlier Donizettian operas this seems to accentuate the soprano's position as a victim right until her endLucia is victimised by the men in the opera - Lady Macbeth's earlier actions prevent her from demanding a similar level of sympathy. Her blood-lust means it is difficult for 
one watching to identify with her, yet she too has been led astray, not by men, but by what Verdi named as the opera's driving force: the witches. Lady Macbeth's offstage death is Shakespeare's, rather than Verdi's doing. In the original play, Macbeth's retort at hearing the women's cry announcing Lady Macbeth's death is impassive: 'I have supped full with horrors. Direness, familiar to my slaughterous thoughts, cannot once start me'. Thus following a pattern becoming all too familiar in Gothic operas, Lady Macbeth fails to die empowered by voice or weapon, or even lamented by her husband. Nonetheless, Lady Macbeth's assertion in the opera's first three Acts would imply an empowered death, that Lady Macbeth be given a final swan song á la Lucia (or Anna, Elisabetta et al), but Verdi's quest for realism and dramatic deepening denies her this. Instead, her 'aria' is fragmented, and is modified towards declamation in the Paris version, as also seen with the melodic line in her Act 1 duet. This is perhaps a fitting operatic 'punishment', for it is indisputable that Lady Macbeth dies from the guilt and horror of her murderous offences. Seen as irrational and overcome by the insanity or altered mental state required by their Gothic frame, the women do not possess the strength of will necessary to either survive or die by their own hand.

The ambiguity of Lucia's quasi-strophic form in 'Regnava nel silenzio' is recalled in Lady Macbeth's mad scene. Lucia's aria is shaped as two quatri of versi ottonari, the confines within which Lady Macbeth also expresses herself. Despite a lack of musical memory, the scene remains one of recollection. Lady Macbeth continues to re-enact her crime, incessantly washing her hands. Her gestures are stuck, her physicality bound to betray her guilt. The libretto, too, in one of the scenes that most closely replicate its original, deviates little from the actions her hands replay. ${ }^{84}$

\footnotetext{
${ }^{84}$ Jane Bernstein has found that the more affective presentations of this scene were not carried out as instructed by both Verdi and Shakespeare - to carry the lamp throughout the scene - but that in placing it down, and allowing the hands to move freely, a more obsessive and horrifying atmosphere could be
} 
Therefore, unlike the earlier operas that relied on musical reminiscence to suggest a fixation on past events, Verdi has constructed his scene as fragmentary; the musical material has been degenerated, rather than restored. As Clausen illustrates, Maffei has incorporated the Lady in waiting and doctor's lines into the rhyme scheme, with an effect that is heightened by her compulsive gestures. ${ }^{85}$ Her conscious versified utterances are as automatic in sleep as her hand washing.

To suggest Lady Macbeth's delusional, fractured mind and unrelenting obsession with her blood-stained hands, her sleepwalking scene is built on an accompaniment of short repetitive melodic or rhythmical phrases (example 3.10). The staccato strings recur throughout, and the lyricism of the second theme (bb. 18-28) is undermined by the incessant staccato passages beneath it. Any stability the clarinet arpeggios illustrate soon give way to the chromatic motive in the strings, clarinet and bassoon to highlight Lady Macbeth's irrationality as the doctor and Lady in Waiting discuss her insanity. In this way, it is similar to the clarinet line in Lucia's cavatina, which persists for much of her cantabile, but disintegrates when she is literally describing her vision.

As Lady Macbeth sings, the music becomes even more repetitively chromatic or moves slowly in small intervals, contrasting with the excess and irrational flamboyancy in her cadenza. The disbanded form of this scene does not extend to the concisely metrical phrasing of the sonnambulismo when Lady Macbeth begins singing, subverting Shakespeare's use of prose to represent madness, relating her formal lines with Macbeth's instances of madness. 
Example 3.11: Lady Macbeth's sonnambulismo, from Act 4, scene 2 of Verdi's Macbeth, bb. 1-78.
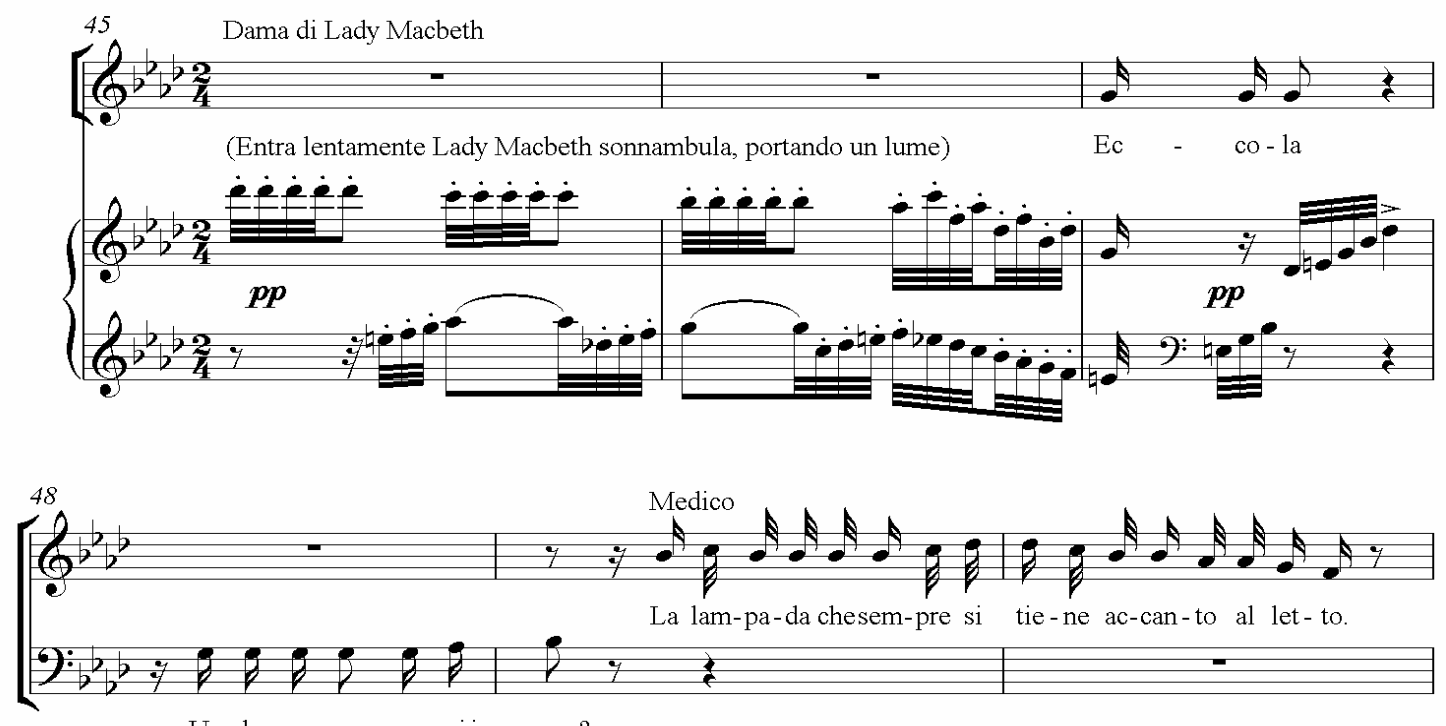

Un lu-me re - ca-si in man?
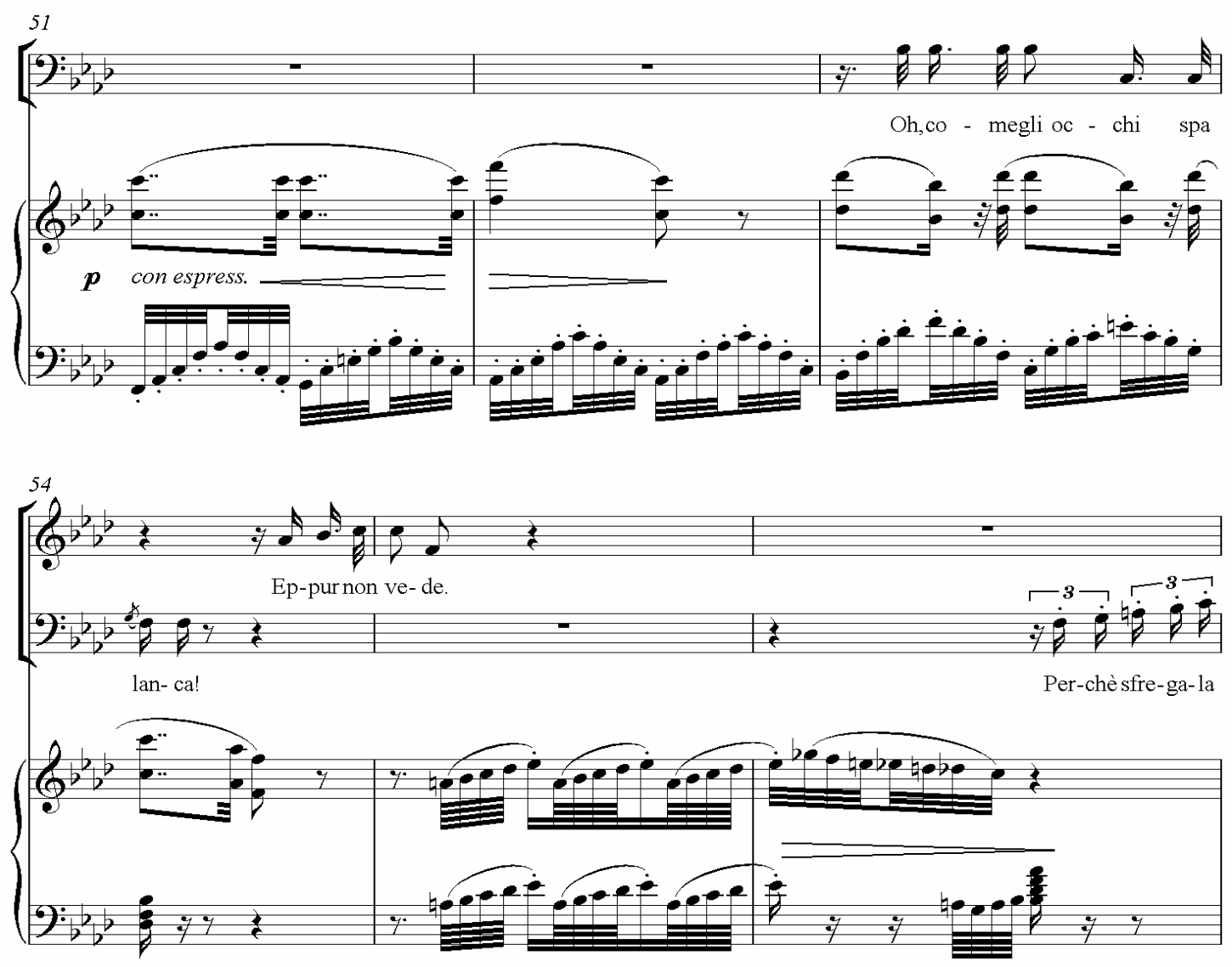
Andante assai sostenuto
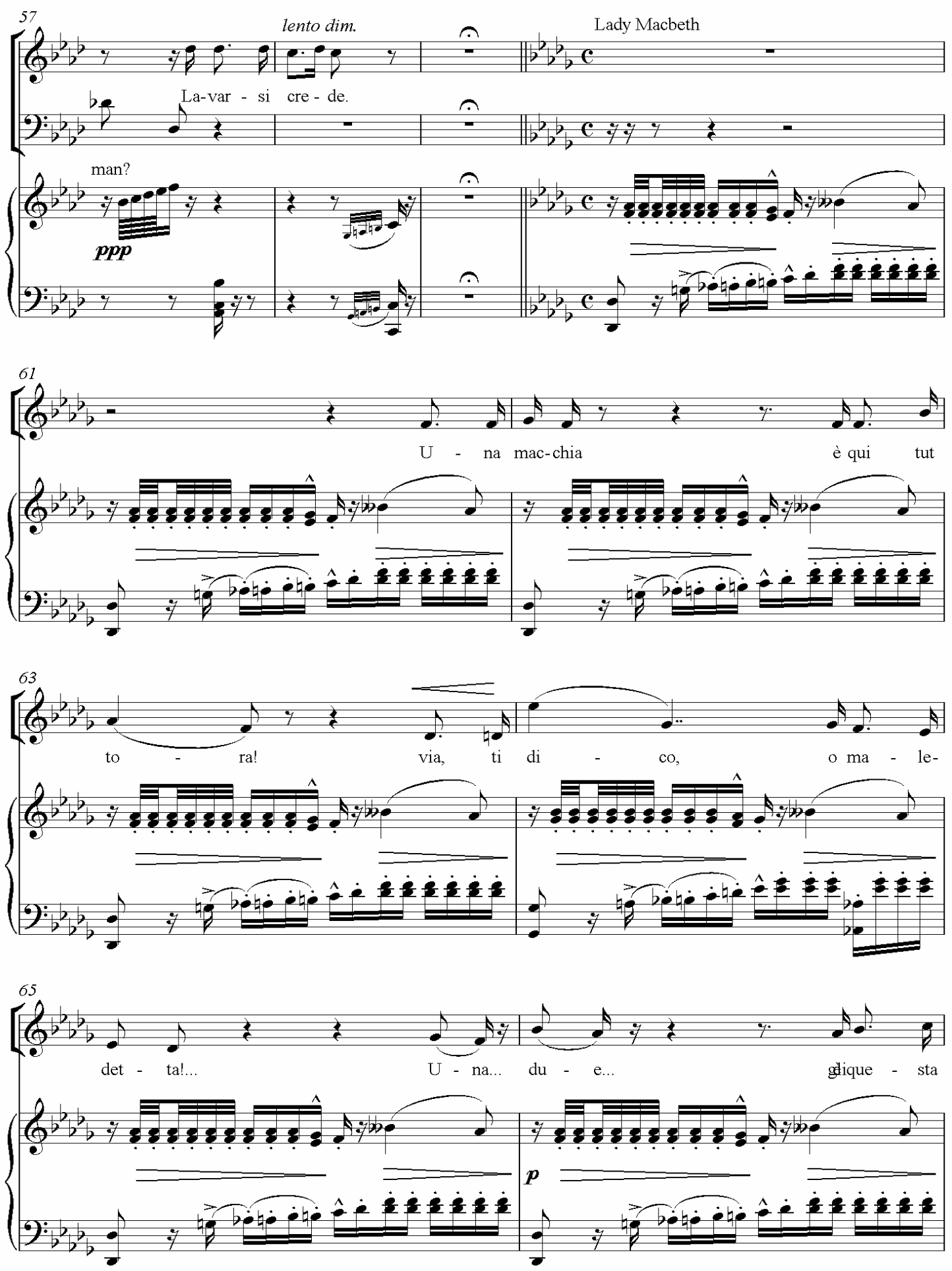

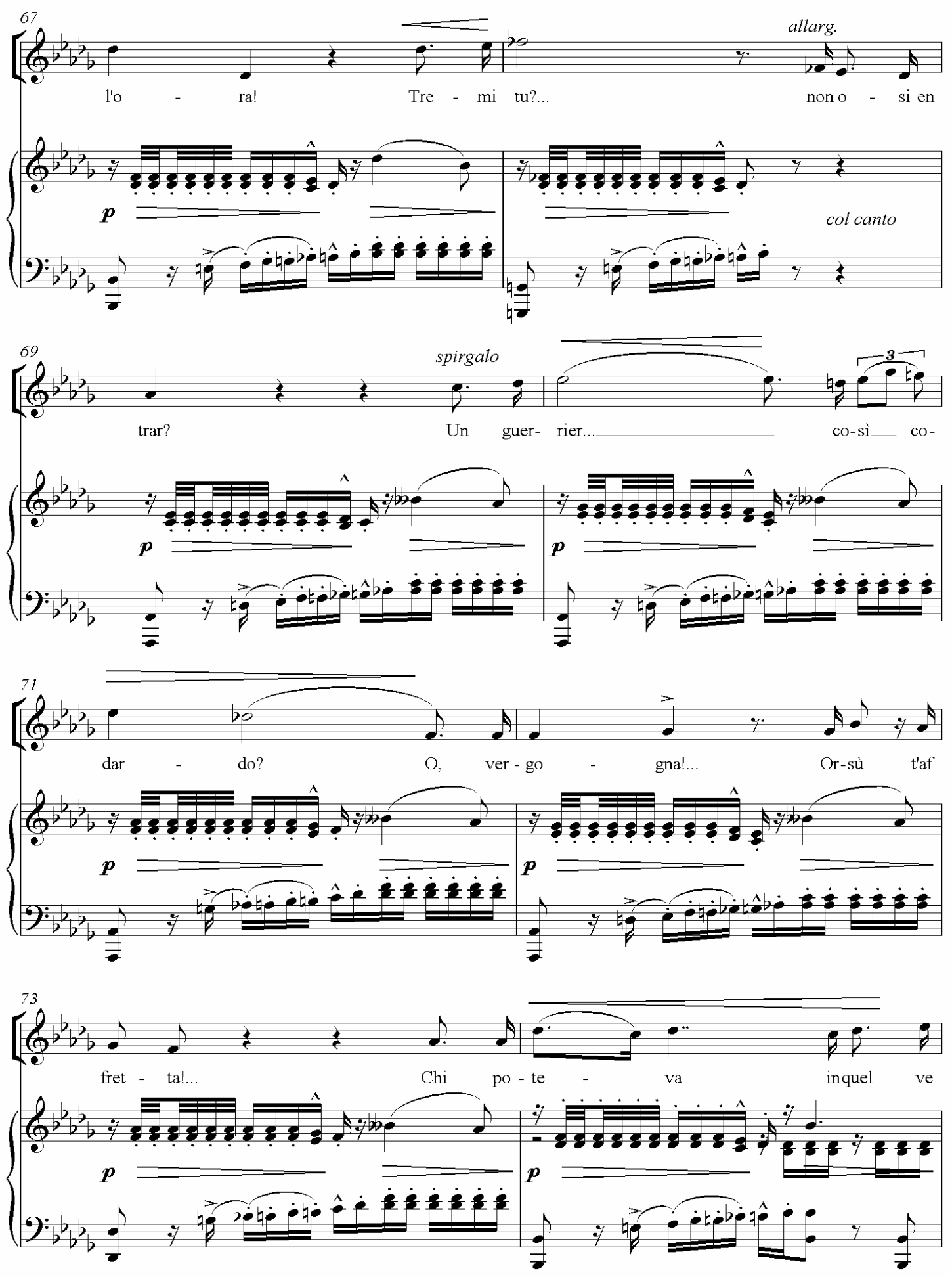

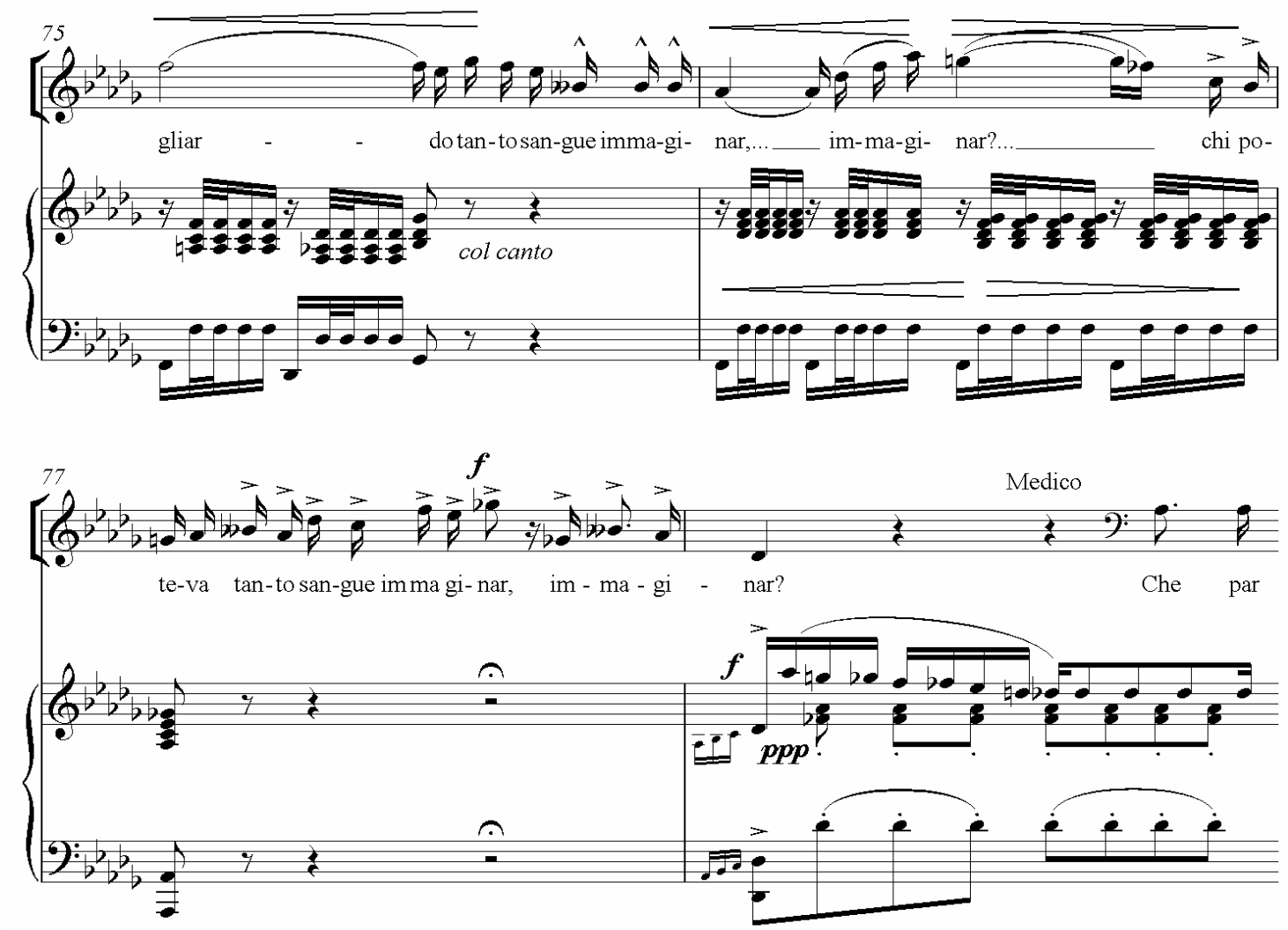

Lady Macbeth's first display of weakness or irrationality is her last. Unlike

Macbeth she is unable to even momentarily recover from her madness. Moreover, this reveals how Macbeth too is subject to the ordinance of the male Gothic. It seems paradoxical that to explore the male Gothic, it is the role of the women who must be investigated, but in the case of Macbeth, the actions of the title character diverge from any of the men hitherto encountered. For apart from Lady Macbeth's infamous mimetic hand washing and her cries of 'out damn'd spot', the majority of the irrational otherworldly elements are found in Macbeth. All supernaturalism in Macbeth, however, originates from the witches: they unveil and control the drama. While Lady Macbeth holds a gendered connection to the witches, which implies that, as a woman, she must in turn also represent all that is foreign, unreasonable or irrational in the opera, the witches confound this association by invoking masculinity. The connection between Lady 
Macbeth and the witches is also less suggestive when it is Macbeth hallucinating, seeing (or even invoking) ghosts and apparitions from the supernatural realms the witches access. Neither the witches nor Lady Macbeth are perturbed by physical brutality and violence (the witches boil dead animals and severed body parts in their cauldron). Although they are sadistic, or at least show cruelty, they are (mostly) musically and physically maligned. Lady Macbeth has no physical experience of the witches and their presence haunts Macbeth more vividly.

Therefore, the Gothic emerges from the witches in Macbeth. They are the fundamental dramatic impetus, and as physical representations of the other-worldly and their affiliations with the supernatural they shift between the phenomenal and noumenal operatic realms. They confound the distinctions of the male and female Gothic conventions, oscillating between female objects of spectacle, otherness and irrationality, and masculine dominating power over the actions of other characters. Their musical impression is felt within the music of other characters at moments where reality is disturbed and the 'unseen' intrudes on visible and audible realms. Rather than these intrusions being represented entirely within the score as a breach of the noumenon, as in Lucia, they exist for the audience to literally see. Banco's ghost is a tangible form which haunts the stage, visible to the audience and Macbeth, but not to the other characters. The witches tread a similarly liminal boundary between seen and invisible realms. Experienced by Macbeth, Banco and the audience alone, they are perceived as an audible, yet invisible force throughout, linking the realms of the Gothic and the operatic in Macbeth. 


\section{Conclusion}

Fascination with the Gothic has diminished little over the last two centuries, and both Lucia di Lammermoor and Macbeth have a presence in today's operatic canon. Perhaps it is the tragic dramatic tension and the Gothic mood of these operas that have actually ensured their endurance. In modern productions, Donizetti's Lucia and Verdi's Macbeth may be removed from their Scottish context, and Macbeth's politicised milieu may be relocated in a different setting, but the Gothic mood remains inherent in the score.

However, in the nineteenth century, arguably the most explicit constructions of the Gothic were through the features of the staging. The use of scenery, costuming and props depicted Scotland and the Gothic as one; the tartan-clothed Scottish people were firmly situated within the misty, dark Gothic landscape of crumbling ruins and ancient tombstones. For the premieres and further nineteenth-century productions of all the operas examined in this study, the literal symbols of the Gothic on stage were fundamental. In addition to its harsh natural landscape, the history of Scotland was visible in the Gothic architectural ruins. In most Italian opera, the research and care taken to ensure the set design and costumes were 'accurate' to the opera's historical period and location enforces this synthesis of northern Europe and the Gothic.

Scotland's inhabitants were often portrayed as irrational, superstitious and uncultivated to the English and continental Europeans through the information these readers and audiences gleaned about the country from popular literature. This northern locale of the operas portrayed the Gothic 'otherness' of Scotland and England to Italian audiences and shows the wide dissemination and influence of British literature. 
Paradoxically, the evocations of 'cheerful Scottish style' in the music of Donizetti's northern operas affirm the connection between the Gothic mood and northern Europe. 'Scottish' musical mannerisms are limited to choral interludes and numbers that have little effect on sustaining the dramatic momentum of the opera. Thus the audible manifestations of couleur locale act independently to situate the Gothic narrative within a Scottish or northern location, thereby enhancing the operas' overall dark Gothic atmosphere. The northern-Gothic landscape is also articulated by the operas' characters and their Gothic encounters. The representations of the characters' imaginations in Donizetti's and Verdi's music propel the drama and connect the metaphysical with what is material and visible onstage. The transcendentalism of the Gothic, passing between physical and abstract realms, is illustrated in the scores and thus resolutely allows the operas considered in this study to become transcendental works themselves.

The Gothic is a 'genre' that, from its literary beginnings in such novels as the Castle of Otranto, develops the psychological boundaries of its characters and the supernatural powers of the imagination. When the Gothic is transferred from the visual arts and literature onto the operatic stage, this movement between the imagination and the physical world is revealed through awareness of sound. Noumenal limits and phenomenal sound may be revealed at different moments for the characters on stage and the audience - and of the characters on stage, not all will show the same sentience with their musical surroundings. Some form of musical disruption accompanies literal evocations of visions or the other-worldly in the libretto, be it the disintegration of solita forma, the recollection of musical themes from earlier in the drama, or a shift in the role of the orchestra or a particular instrument from accompanying to envoicing a character's mente. 
These representations of immateriality are created alongside the musical reminders of the physicality of the singers performing on stage. The more intangible symbols of the characters' Gothic imaginations contrast with the physicality and immediacy fundamental to Italian opera. Semitone movement, accents and string tremolos illustrate the sobs, sighs and wails of Gothic horror and terror. Even these musical sobs themselves can have the ability to transcend their physicality, as the Macbeth lament motive shows. While the characters, and specifically the soprano, are engrossed in their own interiority, they have a visible and audible presence on stage, augmented by the improvisatory nature of coloratura and the associations of spectacle the female body holds. Merging musical depictions of the layers of the mind and operatic performativity creates a tension in ways that denote the uncanniness of the Gothic. However, the capacity for the music to transcend the visible realm of opera does not mean the staging of the opera is any less significant in representing the Gothic. Rather, by emphasising the physical and psychological conditions of the characters, even if the setting of a Gothic opera is relocated in a modern production, the Gothic mood persists nonetheless. The Gothic milieu and the opera's landscape are constructed by the music and experiences of the characters, especially the soprano.

The Gothic imaginations in primo ottocento opera belong to composer, librettist, characters, performers and the audience. Notions of what determines the Gothic have changed considerably over time: from fifteenth-century Italians' interchangeable use of 'Gothic' and 'Germanic', to the grotesque, macabre and supernatural predilections of Romanticism, and to the many incarnations the Gothic 'genre' has acquired in the later nineteenth century and beyond. 'The Gothic' is almost as hard to pin down itself as the inexplicably other-worldly circumstances it embraces. Ghosts in abundance, vampires, zombies, and quasi-Gothic monsters, insinuate themselves into fiction, art, music, and 
more recently into film and subculture. While the setting for the Gothic is no longer confined to medieval castles, subterranean passages of cathedrals or the dark forests and blasted heaths of the north, many familiar themes persist.

Certainly, there are many connections and similarities between opera and the Gothic as 'high' art forms; extravagant, fantastic and irrational. The Gothic, like opera, always presents some degree of 'otherness' to its audience. Besides this, there is the ubiquitous sense that both opera and the Gothic rely on the audience's superstition and ability to suspend their rationality in order to believe in the inexplicable. Most of all, the Gothic continues to fascinate and excite its audience with an anticipation of horror, terror and the monstrous. The operas explored in this study transfer these reactions to the stage. In this respect, the Gothic realises Catherine Clément's assertion that the audience want the soprano's death, they want to 'see' Lucia's ghost and Macbeth's dagger. Furthermore, the audience do see literal emblems of the Gothic: Lucia's bloodsplattered gown, dishevelled hair and hysterical outburst; the disintegration of the Macbeths' consciousnesses; the witches and their apparitions; and Banco's ghost. The Gothic is driven by those same emotions that allow the audience to be carried away by the music, yet much of what the audience wants to 'see' is left up to their own imagination - in the world between the notes and beyond the stage. The Gothic and opera leave their audiences transfixed, captivated and enchanted. Or even, as Italians would say, stregato. 


\section{Appendices}

Appendix 1: Timeline of significant translations and adaptations of the

Ossian Poems.

\begin{tabular}{|c|c|c|c|c|}
\hline YEAR & ITALY & FRANCE & GERMANY & BRITAIN \\
\hline 1760 & & $\begin{array}{l}\text { Fragments V and } \\
\text { XII. Trans. Turgot. } \\
\text { Journal étranger } \\
\text { (Sep.). }\end{array}$ & & $\begin{array}{l}\text { James } \\
\text { Macpherson } \\
\text { publishes } \\
\text { Fragments of } \\
\text { Ancient Poetry: } \\
\text { Collected from } \\
\text { the Highlands of } \\
\text { Scotland and } \\
\text { Translated from } \\
\text { the Gaelic or } \\
\text { Erse Language. }\end{array}$ \\
\hline 1762 & & $\begin{array}{l}\text { First book-length } \\
\text { translation. } \\
\text { First doubts about } \\
\text { the authenticity of } \\
\text { the Works of Ossian } \\
\text { (in Journal des } \\
\text { Sçavans) }\end{array}$ & $\begin{array}{l}\text { Extracts from } \\
\text { 'Carric-thura' } \\
\text { and 'The Songs } \\
\text { of Selma'. } \\
\text { Trans. anon. } \\
\text { Bremisches } \\
\text { Magazin. }\end{array}$ & $\begin{array}{l}\text { Macpherson's } \\
\text { Fingal, an } \\
\text { Ancient Epic } \\
\text { Poem together } \\
\text { with Several } \\
\text { Other Poems } \\
\text { Composed by } \\
\text { Ossian, the Son } \\
\text { of Fingal } \\
\text { published. }\end{array}$ \\
\hline 1763 & $\begin{array}{l}\text { Fingal. Trans. } \\
\text { Cesarotti. } \\
\text { Cesarotti writes to } \\
\text { James Macpherson. }\end{array}$ & & & $\begin{array}{l}\text { Temora } \\
\text { published by } \\
\text { Macpherson }\end{array}$ \\
\hline 1764 & & & $\begin{array}{l}\text { First book-length } \\
\text { translations }\end{array}$ & \\
\hline
\end{tabular}




\begin{tabular}{|c|c|c|c|c|}
\hline 1765 & $\begin{array}{l}\text { Giambattista } \\
\text { Guarducci } \\
\text { publishes Alcune } \\
\text { osservazioni sopra } \\
\text { le poesie di } \\
\text { Ossian. } \\
\text { 320 }\end{array}$ & & & $\begin{array}{l}\text { Macpherson's } \\
\text { The Works of } \\
\text { Ossian, the Son } \\
\text { of Fingal, } \\
\text { Translated from } \\
\text { the Gaelic } \\
\text { Language }\end{array}$ \\
\hline 1768 & & & $\begin{array}{l}\text { First complete } \\
\text { translation of the } \\
\text { Works of Ossian } \\
\text { into any } \\
\text { language. Trans. } \\
\text { M. Denis }\end{array}$ & \\
\hline 1773 & $\begin{array}{l}\text { Second Edition of } \\
\text { Cesarotti's } \\
\text { translation, with the } \\
\text { addition of the } \\
\text { entire Temora and } \\
\text { the Critical } \\
\text { Dissertaion by } \\
\text { Blair. }\end{array}$ & & & \\
\hline 1774 & & & $\begin{array}{l}\text { Goethe publishes } \\
\text { his novel Die } \\
\text { Leiden des } \\
\text { jungen Werthers, } \\
\text { containing } \\
\text { translations of } \\
\text { 'The Songs of } \\
\text { Selma' and } \\
\text { 'Berrathon'. }\end{array}$ & \\
\hline 1777 & & $\begin{array}{l}\text { Full translation of } \\
\text { The Works of } \\
\text { Ossian. Trans. } \\
\text { Pierre Le Tourneur. }\end{array}$ & $\begin{array}{l}\text { Colma, a cantata } \\
\text { by K. E. K. } \\
\text { Schmidt. }\end{array}$ & \\
\hline 1778 & $\begin{array}{l}\text { G. M. Salvi writes } \\
\text { tragedies Calto } \\
\text { (based on 'Calthon } \\
\text { and Colmal') and } \\
\text { Svarano (based on } \\
\text { 'Cath-loda'). }\end{array}$ & & & \\
\hline 1779 & $\begin{array}{l}\text { Osservazioni sopra } \\
\text { I pezzi lirici e } \\
\text { drammatici di } \\
\text { Ossian by } \mathrm{S} . \\
\text { Mattei. }\end{array}$ & & & \\
\hline 1780 & $\begin{array}{l}\text { Reprint of } \\
\text { Cesarotti's } 1772 \\
\text { edition in Nice. } \\
\text { Comala, a } \\
\text { melodrama by R. } \\
\text { de'Calzabigi. }\end{array}$ & & & \\
\hline
\end{tabular}

\footnotetext{
${ }^{320}$ [Some observations on the poems of Ossian]

${ }^{321}$ In 1775, Alfieri develops extracts of Cesarotti's work into dramatic verse, but it remained unpublished until 1969.
} 


\begin{tabular}{|c|c|c|c|}
\hline 1781 & & & $\begin{array}{l}\text { Schiller's drama } \\
\text { Die Räuber. }\end{array}$ \\
\hline 1782 & & & $\begin{array}{l}\text { Schiller's } \\
\text { 'Elegie: Auf den } \\
\text { Tod eines } \\
\text { Jünglings' } \\
\text { contains a } \\
\text { passage } \\
\text { translated from } \\
\text { Ossian. } \\
\text { K. H. } \\
\text { Wachsmuth's } \\
\text { drama Fingal in } \\
\text { Lochlin. }\end{array}$ \\
\hline 1783 & & & $\begin{array}{l}\text { Wachsmuth's } \\
\text { drama } \\
\text { Inamorulla. }\end{array}$ \\
\hline 1784 & $\begin{array}{l}\text { Cesarotti’s Sagio } \\
\text { sulla filosofia delle } \\
\text { lingue. }\end{array}$ & & $\begin{array}{l}\text { Klopstock's } \\
\text { drama Hermann } \\
\text { und Fürsten. }\end{array}$ \\
\hline 1785 & $\begin{array}{l}\text { Cesarotti’s Sagio } \\
\text { sulla filosofia del } \\
\text { gusto. }\end{array}$ & & \\
\hline 1787 & $\begin{array}{l}\text { Extracts from } \\
\text { Smith's Gaelic } \\
\text { Antiquities (first } \\
\text { published in 1780) } \\
\text { are translated by P. } \\
\text { Balbo. }\end{array}$ & & $\begin{array}{l}\text { Klopstock's } \\
\text { drama Hermanns } \\
\text { Tod. }\end{array}$ \\
\hline 1788 & $\begin{array}{l}\text { Calto, a melodrama } \\
\text { by G. Foppa (based } \\
\text { on 'Calthon and } \\
\text { Colmal'). }\end{array}$ & & $\begin{array}{l}\text { The first opera } \\
\text { based on Ossian, } \\
\text { Komala, by F. } \\
\text { Bouterwek is } \\
\text { performed. }\end{array}$ \\
\hline 1790 & $\begin{array}{l}\text { Cesarotti begins to } \\
\text { doubt the } \\
\text { authenticity of The } \\
\text { Poems of Ossian. }\end{array}$ & & \\
\hline 1793 & $\begin{array}{l}\text { Cesarotti's letter to } \\
\text { James Macpherson } \\
\text { is translated into } \\
\text { English in the } \\
\text { Dublin journal } \\
\text { Anthalogia } \\
\text { Hibernica. }\end{array}$ & & \\
\hline 1794 & $\begin{array}{l}\text { F. Sulgher } \\
\text { Fantastici's Poesie, } \\
\text { based on themes } \\
\text { from Ossian. }\end{array}$ & & \\
\hline 1800 & & $\begin{array}{l}\text { Ossian in painting: } \\
\text { Ossian chanting his } \\
\text { poems by P. } \\
\text { Duquerylar. } \\
\text { Madame de Staël } \\
\text { publishes De la } \\
\text { literature. }\end{array}$ & $\begin{array}{l}\text { Ossian drawings } \\
\text { by J. A. Koch (in } \\
\text { two sets). }\end{array}$ \\
\hline
\end{tabular}




\begin{tabular}{|c|c|c|c|c|}
\hline 1801 & $\begin{array}{l}\text { Oscar e Malvina, a } \\
\text { ballet by A. } \\
\text { Landini. } \\
\text { Third edition of } \\
\text { Cesarotti's } \\
\text { translation, with an } \\
\text { essay on the } \\
\text { questionable } \\
\text { authenticity. }\end{array}$ & & & \\
\hline 1802 & & $\begin{array}{l}\text { Girodet's painting } \\
\text { Ossian Receiving the } \\
\text { Generals of the } \\
\text { Republic. }\end{array}$ & & \\
\hline 1803 & $\begin{array}{l}\text { Foscolo's Chioma } \\
\text { di Berenice and } \\
\text { comments on } \\
\text { Italian Ossianism. } \\
\text { Chamber duet: } \\
\text { Calto e Colama by } \\
\text { Foppa, adapted } \\
\text { from his } \\
\text { melodrama. }\end{array}$ & & & \\
\hline 1804 & $\begin{array}{l}\text { L. Casarini's } \\
\text { tragedy Clato. } \\
\text { Ippolito } \\
\text { Pindemonte's } \\
\text { Arminio. }\end{array}$ & $\begin{array}{l}\text { J.-F. Le Sueur's } \\
\text { opera, Ossian, ou } \\
\text { Les Bardes } \\
\text { premieres. } \\
\text { A burlesque of } \\
\text { Ossian, ou Les } \\
\text { Bardes by Allarde } \\
\text { and Désaugiers, Oh! } \\
\text { Que c'est sciant, ou } \\
\text { Oxessian. }\end{array}$ & & \\
\hline 1805 & $\begin{array}{l}\text { L. Fidanza's and S. } \\
\text { Pavesi's drama } \\
\text { Fingallo e Comala. } \\
\text { Colama, A. } \\
\text { Peruzzi's tragedy. }\end{array}$ & & $\begin{array}{l}\text { Death of Oscar } \\
\text { painted by J. A. } \\
\text { Koch. } \\
\text { J. C. Ruch } \\
\text { begins } \\
\text { publishing a } \\
\text { popular series of } \\
\text { illustrated } \\
\text { scenes. }\end{array}$ & \\
\hline 1806 & $\begin{array}{l}\text { Foscolo's 'Le } \\
\text { osservazioni sul } \\
\text { poema del Bardo'. } \\
\text { (Monti's Bardo } \\
\text { della Selva Nera). }\end{array}$ & $\begin{array}{l}\text { Premiere of Méhul's } \\
\text { opera Uthal. }\end{array}$ & & \\
\hline 1807 & $\begin{array}{l}\text { Dei-sepolcri, a } \\
\text { poem-sequence by } \\
\text { Foscolo. }\end{array}$ & & & \\
\hline
\end{tabular}




\begin{tabular}{|c|c|c|c|}
\hline 1809 & & & $\begin{array}{l}\text { The Monk by the } \\
\text { Sea painted by } \\
\text { C. D. Friedrich. } \\
\text { Calthon und } \\
\text { Colmar, a } \\
\text { singspiel by P. } \\
\text { von Winter. }\end{array}$ \\
\hline 1811 & $\begin{array}{l}\text { Foscolo publishes } \\
\text { 'Memoria intorno } \\
\text { ai druidi e ai bardi } \\
\text { britanni' on Celtic } \\
\text { verse. }\end{array}$ & $\begin{array}{l}\text { Premiere of Arnault } \\
\text { and Méhul's cantata } \\
\text { Le Chant d'Ossian. }\end{array}$ & \\
\hline 1812 & $\begin{array}{l}\text { P. Borelli's } \\
\text { Discorsa su I } \\
\text { poemi di Ossian. } \\
\text { Calto e Colama, a } \\
\text { tragic ballet by A. } \\
\text { Fabbri. }\end{array}$ & $\begin{array}{l}\text { Le Songe d'Ossian, a } \\
\text { painting by Ingres. }\end{array}$ & \\
\hline 1815 & & $\begin{array}{l}\text { A pantomime by } \\
\text { Cuvelier, Le } \\
\text { Chef'ecossais, ou La } \\
\text { Caverne d'Ossian. }\end{array}$ & $\begin{array}{l}\text { F. Schubert } \\
\text { begins to set } \\
\text { Ossian extracts } \\
\text { to music (till } \\
\text { 1817) }\end{array}$ \\
\hline 1816 & $\begin{array}{l}\text { G. Rossi's } \\
\text { melodrama } \\
\text { Malvina. }\end{array}$ & & \\
\hline 1817 & $\begin{array}{l}\text { Zibaldone, } \\
\text { including twelve } \\
\text { notes on Ossian by } \\
\text { Leopardi, is } \\
\text { published } \\
\text { posthumously. } \\
\text { The premiere of } \\
\text { three melodrama's: } \\
\text { De Ritis's } \\
\text { Aganadeca; } \\
\text { A. Lorenzoni's } \\
\text { Clato; } \\
\text { G. Bartoli's } \\
\text { Oitona. } \\
\text { A performance of } \\
\text { L. Fidanza's Oscar } \\
\text { e Malvina. } \\
\text { Publication of an } \\
\text { anonymous } \\
\text { collection of } \\
\text { engravings based } \\
\text { on Ossian. }\end{array}$ & & \\
\hline
\end{tabular}




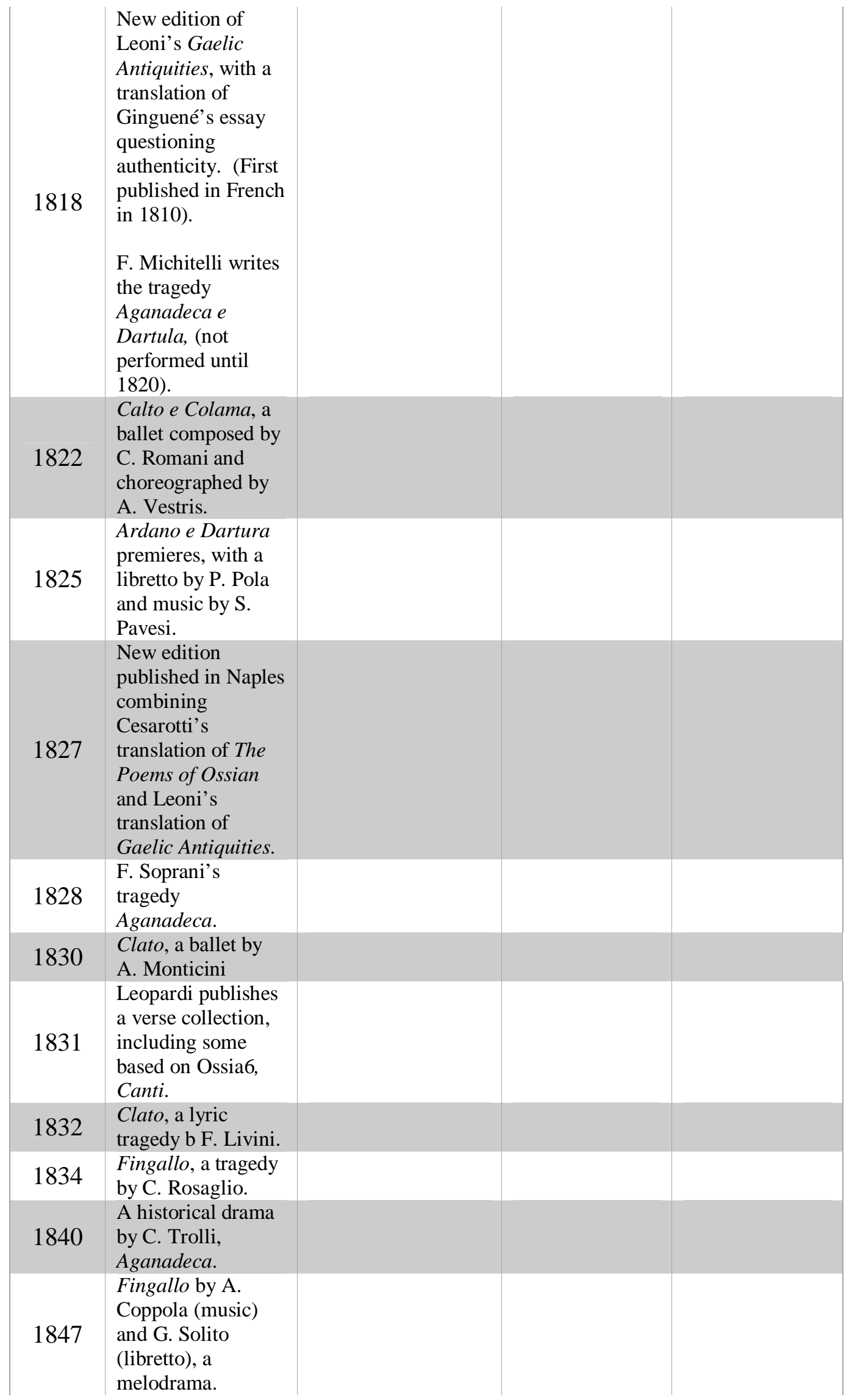


Premiere of

Malvina di Scozia,

1851 music by G. Pacini,

libretto by $S$.

Cammarano.

L. Carrer's 'Gli

ossianisti'

published in Prose.

1855

F. Chiaromonte's

melodrama

Fingallo.

1861

Brahm's Lieder

'Darthulas

Grabesgesang'

and 'Gesang aus

Fingal'. 
Appendix 2: Timeline of significant translations and adaptations of the literature of

Walter Scott.

\begin{tabular}{|c|c|c|c|c|}
\hline YEAR & ITALY & FRANCE & $\begin{array}{c}\text { GERMANY/ } \\
\text { AUSTRIA }\end{array}$ & BRITAIN \\
\hline 1802 & & & & $\begin{array}{l}\text { Scott publishes } \\
\text { Minstrelsy of the } \\
\text { Scottish Border } \\
\text { (Vols. I and II). }\end{array}$ \\
\hline 1803 & & & & $\begin{array}{l}\text { Minstrelsy of the } \\
\text { Scottish Border (Vol. } \\
\text { III) published. }\end{array}$ \\
\hline 1805 & & & & $\begin{array}{l}\text { Scott's The Lay of } \\
\text { the Last Minstrel } \\
\text { Numerous (and often } \\
\text { amateur) composers } \\
\text { begin to set Scott's } \\
\text { poetry as songs in } \\
\text { England and } \\
\text { Scotland, including } \\
\text { John Clarke and } \\
\text { Joseph Mazzinghi. }\end{array}$ \\
\hline 1808 & & & & $\begin{array}{l}\text { Scott publishes } \\
\text { Marmion. }\end{array}$ \\
\hline 1810 & & & $\begin{array}{l}\text { First German } \\
\text { Translation: } \\
\text { (extracts } \\
\text { From Minstrelsy } \\
\text { of the Scottish } \\
\text { Border). }\end{array}$ & $\begin{array}{l}\text { The Lady of the Lake } \\
\text { published. }\end{array}$ \\
\hline 1813 & & $\begin{array}{l}\text { First French } \\
\text { Translation: The } \\
\text { Lady of the Lake. }\end{array}$ & & Rokeby published. \\
\hline 1815 & & & $\begin{array}{l}\text { Beethoven, } 25 \\
\text { Scottish Songs, } \\
\text { op. } 108, \\
\text { including } \\
\text { settings of Scott. }\end{array}$ & $\begin{array}{l}\text { Guy Mannering } \\
\text { published. }\end{array}$ \\
\hline 1816 & & $\begin{array}{l}\text { Translated } \\
\text { extracts from Guy } \\
\text { Mannering } \\
\text { published. }\end{array}$ & $\begin{array}{l}\text { Translated } \\
\text { extracts from } \\
\text { Guy Mannering } \\
\text { published. }\end{array}$ & \\
\hline 1817 & & $\begin{array}{l}\text { First complete } \\
\text { novels translated } \\
\text { (Rob Roy, } \\
\text { Waverley, Heart } \\
\text { of the Mid- } \\
\text { Lothian). }\end{array}$ & $\begin{array}{l}\text { First complete } \\
\text { novels } \\
\text { translated (Guy } \\
\text { Mannering, } \\
\text { Minstrelsy of } \\
\text { the Scottish } \\
\text { Border). }\end{array}$ & \\
\hline 1818 & & & & $\begin{array}{l}\text { Scott publishes } \\
\text { Heart of the Mid- } \\
\text { Lothian. }\end{array}$ \\
\hline
\end{tabular}




\begin{tabular}{|c|c|c|c|c|}
\hline 1819 & $\begin{array}{l}\text { Premiere of } \\
\text { Rossini's La } \\
\text { Donna del lago, } \\
\text { with libretto by } \\
\text { Andrea Leone } \\
\text { Tottola. }\end{array}$ & $\begin{array}{l}\text { Hugo reviews Lay } \\
\text { of the Last } \\
\text { Minstrel and The } \\
\text { Bride of } \\
\text { Lammermoor in } \\
\text { Le Conservateur } \\
\text { littéraire. }\end{array}$ & & $\begin{array}{l}\text { The Bride of } \\
\text { Lammermoor } \\
\text { published. }\end{array}$ \\
\hline 1820 & & & & $\begin{array}{l}\text { The Monastery and } \\
\text { Ivanhoe published. }\end{array}$ \\
\hline 1821 & $\begin{array}{l}\text { First Italian } \\
\text { translations: The } \\
\text { Lady of the Lake } \\
\text { and Kenilworth. } \\
\text { (Giuseppe } \\
\text { Indelicato's } \\
\text { La Dama del } \\
\text { Lago, Palermo } \\
\text { and Jedediah } \\
\text { Cleisbotham's La } \\
\text { prigione di } \\
\text { Edimburgo o } \\
\text { nuovi racconti del } \\
\text { mio ostiere, } \\
\text { Milan). }\end{array}$ & $\begin{array}{l}\text { Delacroix, Self- } \\
\text { Portrait as } \\
\text { Ravenswood. } \\
\\
\text { Ducange, La } \\
\text { Sorcière, ou } \\
\text { L'Orphelin } \\
\text { Ecossaise. } \\
\text { Melodrama (from } \\
\text { Guy Mannering). }\end{array}$ & & $\begin{array}{l}\text { Kenilworth } \\
\text { published. }\end{array}$ \\
\hline 1822 & $\begin{array}{l}\text { Sebastiano Nistre } \\
\text { publishes a } \\
\text { translation of } \\
\text { Tales of my } \\
\text { Landlord, second } \\
\text { series, later } \\
\text { published as } \\
\text { Heart of } \\
\text { Midlothian. } \\
\text { Translations of } \\
\text { Ivanhoe, The Tale } \\
\text { of Old Mortality, } \\
\text { Waverley and The } \\
\text { Lay of the Last } \\
\text { Minstrel also } \\
\text { appear. }\end{array}$ & & $\begin{array}{l}\text { Lembert and } \\
\text { Lenz based } \\
\text { dramas on } \\
\text { Kenilworth. }\end{array}$ & \\
\hline 1823 & $\begin{array}{l}\text { Annibale in } \\
\text { Britania; dramma } \\
\text { eroico in } 2 \text { atti, by } \\
\text { Giuseppe } \\
\text { Nicolini, Bologna } \\
\text { Elisabetta, Regina } \\
\text { d'Inghilterra, al } \\
\text { castello di } \\
\text { Kenilworth; Ballo } \\
\text { tragico in cinque } \\
\text { atti, by Giovanni } \\
\text { Galzerani, } \\
\text { Bologna. }\end{array}$ & $\begin{array}{l}\text { Auber's Leicester, } \\
\text { Paris, } \\
\text { (Kenilworth). } \\
\text { Fétis's Marie } \\
\text { Stuart en Écosse, } \\
\text { Paris (The Abbot) } \\
\\
\text { Nodier publishes } \\
\text { Oeuvres } \\
\text { Complètes de } \\
\text { Walter Scott. }\end{array}$ & & \\
\hline 1824 & $\begin{array}{l}\text { La promessa } \\
\text { sposa di } \\
\text { Lammermoor, } \\
\text { translated by } \\
\text { Jedediah } \\
\text { Cleishbotham. }\end{array}$ & $\begin{array}{l}\text { Lucy Ashton's } \\
\text { Bridal Night } \\
\text { sketched by } \\
\text { Delacroix. }\end{array}$ & & \\
\hline
\end{tabular}




\begin{tabular}{|c|c|c|c|}
\hline 1825 & $\begin{array}{l}\text { Gaetano } \\
\text { Barbieri's } \\
\text { Racconti del mio } \\
\text { ostiere, o sia, I } \\
\text { puritani di Scozia } \\
\text { and Il nano } \\
\text { misterioso } \\
\text { published in } \\
\text { Naples. }\end{array}$ & $\begin{array}{l}\text { Boieldieu's La } \\
\text { Dame Blanche } \\
\text { (based on Guy } \\
\text { Mannering), } \\
\text { Paris. }\end{array}$ & \\
\hline 1826 & $\begin{array}{l}\text { La promessa } \\
\text { sposa di } \\
\text { Lammermoor,tran } \\
\text { slated by Gaetano } \\
\text { Barbieri }\end{array}$ & $\begin{array}{l}\text { Rossini, Ivanhoé, } \\
\text { Paris. }\end{array}$ & $\begin{array}{l}\text { Schubert, } \\
\text { Sieben Gesänge, } \\
\text { (Vienna). }\end{array}$ \\
\hline 1827 & $\begin{array}{l}\text { L'antiquario and } \\
\text { Il lord delle isole: } \\
\text { poema in sei } \\
\text { canti, translated } \\
\text { by Pietro Borsieri } \\
\text { (Naples). }\end{array}$ & $\begin{array}{l}\text { Adolphe Adam, } \\
\text { Le Caleb de } \\
\text { Walter Scott, } \\
\text { Paris (The Bride } \\
\text { of } \\
\text { Lammermoor). } \\
\text { Hugo's Cromwell } \\
\text { Dramatic } \\
\text { adaptation of The } \\
\text { Tales of Old } \\
\text { Mortality by } \\
\text { Dumas and } \\
\text { Soulié. }\end{array}$ & \\
\hline 1828 & $\begin{array}{l}\text { Vincenzo Lancetti } \\
\text { translates Storia } \\
\text { del tempo di } \\
\text { Cromvello, Il } \\
\text { cavaliere and } \\
\text { Woodstock. } \\
\text { Milan; } \\
\text { Gaetano Barbieri } \\
\text { translates Rob } \\
\text { Roy, Il } \\
\text { Monastero, and } \\
\text { L'abate: } \\
\text { continuazione del } \\
\text { monastero } \\
\text { (Naples). } \\
\text { Soggetti tratti dall' } \\
\text { Ivanhoe: romanzo } \\
\text { storico, translated } \\
\text { by Francesco } \\
\text { Hayez. }\end{array}$ & $\begin{array}{l}\text { Auber, La Muette } \\
\text { di Portici } \\
\text { (Premiere in } \\
\text { Brussels) } \\
\text { Hugo's Amy } \\
\text { Robsart. }\end{array}$ & \\
\hline 1829 & $\begin{array}{l}\text { Donizetti's } \\
\text { Elisabetta al } \\
\text { Castello di } \\
\text { Keniworth, } \\
\text { Naples } \\
\text { (Kenilworth and } \\
\text { Victor Hugo's } \\
\text { Amy Robsart) }\end{array}$ & $\begin{array}{l}\text { Le Nozze di } \\
\text { Lammermoor by } \\
\text { Carafa, } \\
\text { Paris (The Bride } \\
\text { of } \\
\text { Lammermoor). }\end{array}$ & \\
\hline
\end{tabular}




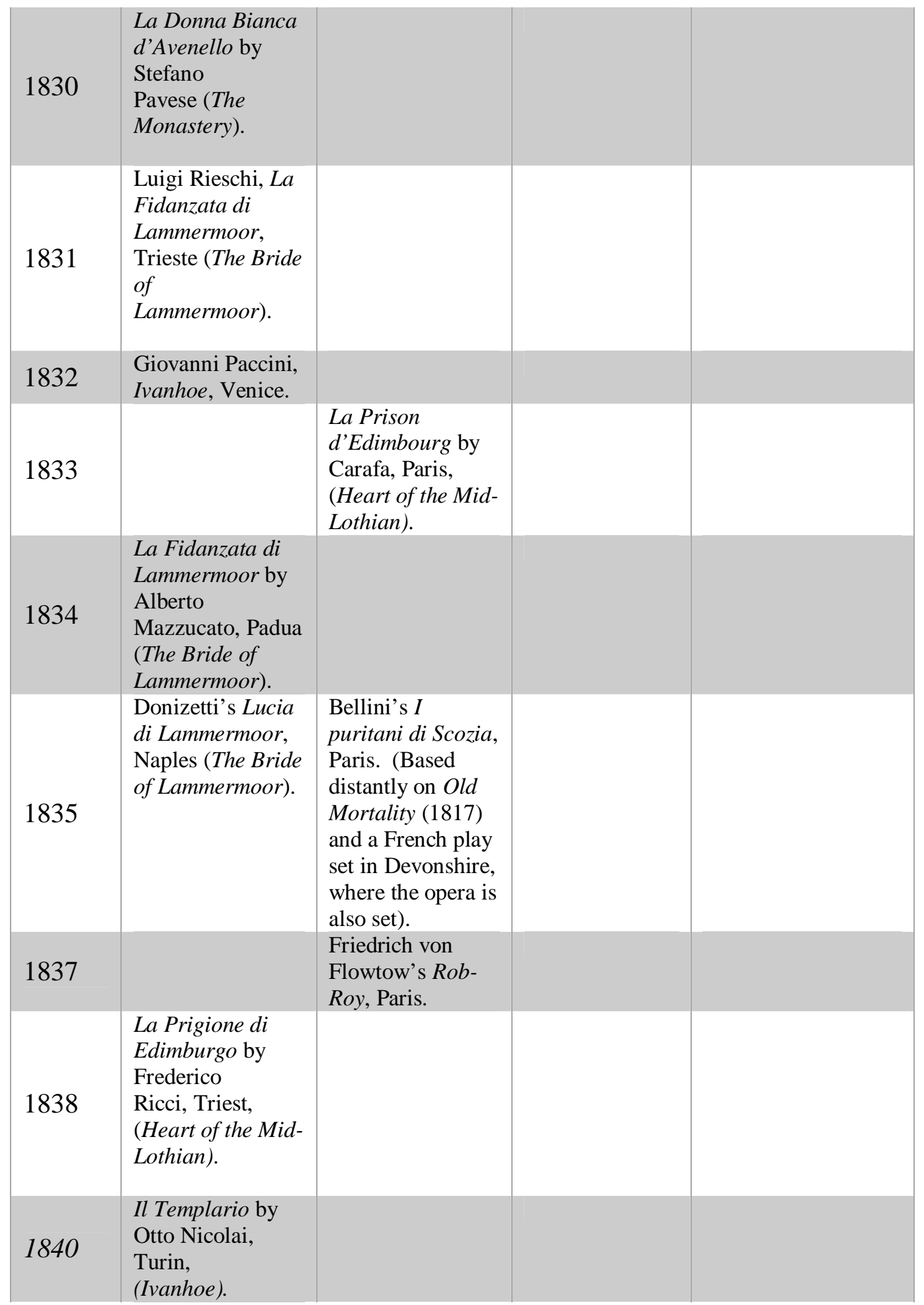


Appendix three: Donizetti's Gothic and British Operas

\begin{tabular}{|c|c|c|c|}
\hline $\begin{array}{l}\text { Year of } \\
\text { Premiere }\end{array}$ & Title & Setting & Additional Information \\
\hline 1824 & Emilia di Liverpool & England & $\begin{array}{l}\text { An opera semiseria which conveys } \\
\text { nothing of the Gothic. Performed } \\
\text { in a revised version in } 1828 \text {. }\end{array}$ \\
\hline 1826 & Gabriella di Vergy & France & Revised in 1838 \\
\hline 1829 & $\begin{array}{l}\text { Elisabetta al Castello } \\
\text { di Kenilworth }\end{array}$ & England & $\begin{array}{l}\text { Based on Scott's Kenilworth } \\
\text { (1821) and Hugo's Amy Robsart } \\
\text { (1828) }\end{array}$ \\
\hline 1830 & Anna Bolena & England & Based on Tudor history. \\
\hline 1832 & Sancia di Castiglia & Spain & $\begin{array}{l}\text { Plot similarities with Lucrezia } \\
\text { Borgia. }\end{array}$ \\
\hline \multirow[t]{2}{*}{1833} & Parisina & Spain & Based on Byron's Parisina (1816). \\
\hline & Lucrezia Borgia & Italy & $\begin{array}{l}\text { Based on Hugo's Lucrèce Borgia } \\
\text { (1833). }\end{array}$ \\
\hline \multirow[t]{2}{*}{1834} & $\begin{array}{l}\text { Rosmonda } \\
\text { d'Inghilterra }\end{array}$ & England & An opera seria, but not Gothic. \\
\hline & Gemma di Vergy & France & \\
\hline \multirow[t]{2}{*}{1835} & $\begin{array}{l}\text { Lucia di } \\
\text { Lammermoor }\end{array}$ & Scotland & $\begin{array}{l}\text { Based on Scott's The Bride of } \\
\text { Lammermoor (1819). }\end{array}$ \\
\hline & Maria Stuarda & England & $\begin{array}{l}\text { Premiered as Buondelmonte, based } \\
\text { on Schiller's Maria Stuart (1800), } \\
\text { in turn based on Tudor history. }\end{array}$ \\
\hline 1837 & $\begin{array}{l}\text { Roberto Devereux, } \\
\text { Conte d'Essex }\end{array}$ & England & Based on Tudor history. \\
\hline 1838 & Maria di Rudenz & France & $\begin{array}{l}\text { Based on Matthew Lewis's Gothic } \\
\text { novel The Monk (1795). }\end{array}$ \\
\hline
\end{tabular}




\section{Bibliography}

Abbate, Carolyn. Unsung Voices: Opera and Musical Narrative in the

Nineteenth Century. Princeton: Princeton University Press, 1991.

- $\quad$ 'Opera; or, the Envoicing of Women'. In Musicology and Difference: Gender and Sexuality in Musical Scholarship, edited by Ruth A. Solie. Berkeley: University of California Press, 1989.

Aldrich, Megan. Gothic Revival. London: Phaidon, 1994

André, Naomi. Voicing Gender: Castrati, Travesti, and the Second Woman in Early-Nineteenth-Century Italian Opera. Bloomington: Indiana University Press, 2006.

- $\quad$ 'Women's roles in Meyerbeer's operas: How Italian heroines are reflected in French grand opera'. In Opera and Society in Italy and France from Monteverdi to Bourdieu, edited by Victoria Johnson, Jane F. Fulcher and Thomas Ertman. Cambridge: Cambridge University Press, 2007, pp. 87-114.

Atkinson, Paul. 'Gothic Imaginations'. Social Studies of Science, Vol. 35, No. 4, 2005, pp. 653-64.

Ashbrook, William. Donizetti. Norwich: Jarrold and Sons, 1965.

- $\quad$ Donizetti and his Operas. Cambridge: Cambridge University Press, 1982.

- $\quad$ 'Popular Success: The Critics and Fame, the early Careers of Lucia di Lammermoor and Belisario'. Cambridge Opera Journal, Vol. 2, No. 1 (March, 1990), pp. 65-81.

- 'Lucia di Lammermoor'. Grove Dictionary of Music Online. Oxford Music Online. http://www.oxfordmusiconline.com. (23 March 2008).

- 'Anna Bolena'. The New Grove Dictionary of Opera Online. Oxford Music Online. http://www.oxfordmusiconline.com. (2 July 2009).

Baker, Evan. 'Verdi's Operas and Giuseppe Bertoja's Designs at the Gran Teatro La Fenice, Venice'. In Opera in Context: essays on historical staging from the late Renaissance to the time of Puccini, edited by Mark Radice. Oregon: Amadeus Press, 1998, pp. 209-40.

Balthazar, Scott. 'Rossini and the Development of Mid-Century Lyric Form'. 
Journal of the American Musicological Society, Vol. 41, No. 1 (1988), pp. 10225.

Barnaby, Paul. 'Ossian's Reception in Europe'. In The Reception of Ossian in Europe, edited by Howard Gaskell. London: Thoemmes Continuum, 2004, pp. xxilxviii.

Bernstein, Jane A. '"Bewitched, bothered and bewildered": Lady Macbeth, sleepwalking, and the demonic in Verdi's Scottish opera'. Cambridge Opera Journal, Vol. 14, No. 1 (March 2002), pp. 31-46.

Bienstock, Ruth. 'The Missing Mother: The Meanings of Maternal Absence in the Gothic Mode'. Modern Language Studies, Vol. 33, No. 1 (2003), pp. 25-43.

Billiani, Francesca and Gigliola Sulis. The Italian Gothic and the Fantastic: Encounters and Rewritings of Narrative Traditions. Madison: Fairleigh Dickinson University Press, 2007.

Bini, Annalisa and Jeremy Commons. Le prima reppresentatazioni delle opere di Donizetti nella stampa coeva. Milan: Skira, 1997.

Black, John. The Italian Romantic Libretto: A Study of Salvadore Cammarano. Edinburgh: Edinburgh University Press, 1984.

- 'Cammarano's Notes for the Staging of Lucia di Lammermoor'. Donizetti Society Journal, Vol. 4, 1980, pp. 28-45.

Bleiler, Ellen H., Lucia di Lammermoor, Gaetano Donizetti: Complete Companion to the Opera. New York: Dover, 1972.

Booth, Michael R. 'Macbeth and the Nineteenth-Century Theatre'. In Giuseppe Verdi: 'Macbeth', edited by Nicholas John. New York: Riverrun, 1990.

Broggi-Würthrich. 'From Smith's Antiques to Leonie's Nuovi Canti: The Making of the Italian Ossianic Tradition Revisited'. In The Reception of Ossian in Europe, edited by Howard Gaskell. London: Thoemmes Continuum, 2004, pp. 303-34.

Brooks, Chris. The Gothic Revival. London: Phaidon, 1999.

Brooks, Peter. 'Body and Voice in Melodrama and Opera'. In Siren Songs: Representations of Gender and Sexuality in Opera, edited by Mary Ann Smart. Princeton: Princeton University Press, 2000, pp. 118-34.

Brown, Marshall. The Gothic Text. Stanford: Stanford University Press, 2005.

Budden, Julian. The Operas of Verdi: From Oberto to Rigoletto. Oxford: Oxford University Press, 1991.

Burgess, Anthony. Mozart and the Wolfgang. London: Vintage, 1994. 
Burke, Edmund. A Philosophical Enquiry into the Origin of our Ideas of the Sublime and the Beautiful, edited by James T. Boulton. New York: Routledge, 2008.

Cavallaro, Dani. The Gothic Vision: Three Centuries of Horror, Terror, and Fear. London: Continuum, 2002.

Clausen, Christophe. Macbeth Multiplied: Negotiating Historical and Medial Difference between Shakespeare and Verdi. Amsterdam and New York: B. V. Rodopi, 2005.

Clément, Catherine. Opera, or the Undoing of Women, translated by Betsey Wing. London: Virago Press, 1989.

- $\quad$ 'Through Voices, History'. In Siren Songs: Representations of Gender and Sexuality in Opera, edited by Mary Ann Smart. Princeton: Princeton University Press, 2000, pp. 17-28.

Cohen, H. Robert. The original staging manuals of ten Parisian operatic premiers, 1824-1843. New York: Pendragon Press, 1998.

Coleridge, Samuel Taylor. Coleridge's Poetry and Prose, edited by Nicholas Halmi, Paul Magnuson and Raimonda Modiano. New York: Norton, 2004.

- 'Notes on Macbeth'. In The Literary Remains of Samuel Taylor Coleridge, Vol. 2, edited by Henry Nelson Coleridge. London: William Pickering, 1836.

Collison, Francis. The Traditional and National Music of Scotland. London: Routledge and Keegan Paul, 1966.

- 'Reel'. In Grove Music Online. Oxford Music Online. http://www.oxfordmusiconline.com/subscriber/article/grove/music/23050. (8 April 2010).

- 'Strathspey'. In Grove Music Online. Oxford Music Online. http://www.oxfordmusiconline.com/subscriber/article/grove/music/26909. (8 April 2010).

Collison-Morley, Lacy. Shakespeare in Italy. New York: Benjamin Bloom, 1916.

Conati, Marcello. 'Aspects of the Production of Macbeth'. In Verdi's 'Macbeth': A Sourcebook, edited by David Rosen and Andrew Porter. Cambridge: Cambridge University Press, 1984.

Daverio, John, 'Schumann's Ossianic Manner'. 19 th $^{\text {th }}$ Century Music, Vol, 21, No. 3 (1998), pp. 247-73.

Day-O'Connell, Jeremy. Pentatonicism from the Eighteenth Century to Debussy. Rochester: University of Rochester Press, 2007. 
Dean, Winton. 'Shakespeare in the Opera House'. In Essays on Opera. Oxford: Oxford University Press, 1965.

DeLamotte, Eugenia C. Perils of the Night: A Feminist Study of Nineteenth-Century Gothic. Oxford: Oxford University Press, 1990.

Donizetti, Gaetano. Anna Bolena: tragedia lirica in due atti. Libretto by Felice Romani. Milan: Ricordi, 2006.

- Lucrezia Borgia: melodrama in un prologo e due atti. Libretto by Felice Romani. Milan: Ricordi, 1996.

- $\quad$ Roberto Devereux, Conte d'Essex. Libretto by Salvadore Cammerano. Van Nuys: Kalmus, 1975.

- $\quad$ Lucia di Lammermoor: drama tragico in die parti. Libretto by Salvadore Cammerano. Milan: Ricordi, 2004.

- $\quad$ Maria Stuarda: tragedia lirica in die atti. Libretto by Giuseppe Bardari. Milan: Ricordi, 1998.

Ellis, Markman. The History of Gothic Fiction. Edinburgh: Edinburgh University Press, 2000.

Esse, Melina. “'Chi piange, qual forza m'arretra?”: Verdi's Interior Voices'. Cambridge Opera Journal, Vol. 14, No. 1 (March, 2002), pp. 59-78.

- $\quad$ 'Donizetti's Gothic Resurrections', Nineteenth-Century Music, Vol. 33, No. 2 (2009), pp. 81-109.

Everist, Mark. 'Partners in Rhyme: Alphonse Royer, Gustave Vaëz, and foreign opera in Paris during the July Monarchy'. In Fashion and Legacies of Nineteenth-Century Italian Opera, edited by Roberta Montemorra Martin and Hilary Poriss. Cambridge: Cambridge University Press, 2009, pp. 30-52.

Everett, William A. 'National Themes in Scottish Art Music, ca. 1880-1900, International Review of the Aesthetics and Sociology of Music, Vol. 30, No. 3 (1999), pp. 151-71.

Feldman, Martha. 'The Absent Mother in Opera Seria'. In Siren Songs: Representations of Gender and Sexuality in Opera, edited by Mary Ann Smart. Princeton: Princeton University Press, 2000, pp. 29-46.

Ferguson, William. The Identity of the Scottish Nation. Edinburgh: Edinburgh University Press, 1998.

Fischer, Ernst Ludwig. The Scots in Germany: Being a Contribution towards the History of the Scot Abroad. Edinburgh: Edinburgh University Press, 1974.

Fiske, Roger. Scotland in Music: A European Enthusiasm. Cambridge: Cambridge 
University Press, 1983.

- $\quad$ and George Biddlecombe. 'Scott, Sir Walter'. In Grove Music Dictionary Online. Oxford Music Online. http://www.oxfordmusiconline.com, (26 May 2009).

Flaubert, Gustave. Madame Bovary. Translated by Francis Steegmuller. London: David Campbell, 1993.

Gelbart, Matthew. The Invention of "Folk Music" and "Art Music", Cambridge: Cambridge University Press, 2007.

Gossett, Philip. 'Anna Bolena' and the Artistic Maturity of Gaetano Donizetti. Oxford: Clarendon Press, 1985.

- Divas and Scholars: Performing Italian Opera. Chicago: Chicago University Press, 2006.

- "Edizioni distrutte" and the significance of operatic choruses during the Risorgimento'. In Opera and Society in Italy and France from Monteverdi to Bourdieu, edited by Victoria Johnson, Jane F. Fulcher and Thomas Ertman. Cambridge: Cambridge University Press, 2007, pp. 181-242.

Grey, Thomas S. 'Finegal's Cave and Ossian's Dream: Music, Image and Phantasmagoric Audition'. In The Arts Entwined: Music and Painting in the Nineteenth Century, edited by Marsha L. Morton and Peter L. Schmunk. New York: Garland Publishing, 2000, pp 63-100.

Guccini, Gerardo. 'Directing Opera'. In Opera on Stage, edited by Lorenzo Bianco and Giorgio Pestelli and translated by Kate Singleton. Chicago: Chicago University Press, 2002, pp. 125-76.

Hadlock, Heather. 'Sonorous Bodies: Women and the Glass Harmonica'. Journal of the American Musicological Society, Vol. 53, No. 3 (2000), pp. 507-42.

Hale, Terry. 'French and German Gothic: The Beginnings'. In The Cambridge Companion to Gothic Fiction, edited by Jerrold E. Hogle. Cambridge: Cambridge University Press, 2001, pp. 63-84.

Hall, Michael. Gothic Architecture and its Meanings 1550-1830. Reading: Spire books, 2002.

Hall-Witt, Jennifer. Fashionable Acts: Opera and Elite Culture in London 17801880. Durham: University of New Hampshire Press, 2007.

Harris-Warrick, Rebecca. 'Lucia Goes to Paris: A Tale of Three Theaters'. In Stage Music and Cultural Transfer: Paris, 1830-1914, edited by Annegret Fauser and Mark Everist. Chicago: Chicago University Press, 2009, pp. 195-227.

Heiland, Donna. Gothic and Gender: An Introduction. Malden: Blackwell, 2004. 
Hibberd, Sarah. 'Murder in the Cathedral? Stradella, Musical Power, and Performing the Past in 1830s Paris.' Music and Letters, Vol. 87, No. 4, 2006, pp. 551-79.

- $\quad$ French Grand Opera and the Historical Imagination. Cambridge: Cambridge University Press, 2009.

Hudson, Elizabeth. ““...Qualche cosa d'incredibile...”: Hearing the Invisible in Macbeth'. Cambridge Opera Journal, Vol. 14, No. 1 (March 2002), pp. 11-29.

Hugo, Victor. 'Preface' to Cromwell. In Théatre: Les trois premiers actes de Cromwell, Hetzel: Paris, 1858.

Hugo, Victor. 'Preface' to Cromwell. In Prefaces and Prologues to Famous Books: Part 39, edited by Charles W. Eliot and translated by Andrew Motte. Harvard Classics, 1910.

Jenkins, David and Mark Visocchi. Mendelssohn in Scotland. London: Chappell and Company, 1978.

Kerman, Joseph. Opera as Drama, 2ed. Berkeley: University of California Press, 2005.

Kidson, Peter, et al. 'Gothic'. In Grove Art Online. Oxford Art Online, http://www.oxfordartonline.com/subscriber/article/grove/art/T033435pg6. (29 April 2009).

Kimbell, David R. B. Verdi in the Age of Italian Romanticism. Cambridge: Cambridge University Press, 1981.

- $\quad$ Italian Opera. Cambridge: Cambridge University Press, 1991.

Lindenberger, Herbert. Opera: The Extravagant Art. Ithaca: Cornell University Press, 1984.

Locke, Ralph P. Musical Exoticism: Images and Reflection. Cambridge: Cambridge University Press, 2009.

Luzzi, Joseph. 'Did Italian Romanticism Exist?' Comparative Literature, Vol. 56, No. 2, Spring 2004, pp. 168-91.

MacDonald, Hugh. 'The Outre-Manche in $19^{\text {th }}$-Century French Operas'. In D'un opera l'autre: Homage à Jean Mongrédien, edited by Jean Gribenski. Paris: 1996, pp. 155-62.

MacVicar Grant, Anne. Essays on the Superstitions of the Highlanders of Scotland: 
to which are added, translations from the Gaelic; and letters connected with those formerly published in two volumes by the author of "Letters from the Mountains." London: Longman et al, 1811.

McClary, Susan. Feminine Endings: Music, Gender, and Sexuality. Minneapolis: University of Minnesota Press, 1991.

Mattodia, Enrico. 'Ossian in Italy: From Cesarotti to the Theatre'. In The Reception of Ossian in Europe, edited by Howard Gaskell. London: Thoemmes Continuum, 2004, pp. 275-301.

Mazzini, Giuseppe. Filosofia della Musica, translated by Emilie Venturi and edited by Franco Sciannameo. New York: Edwin Mellen Press, 2004.

Mikusi, Balázs. 'Mendelssohn's Scottish Tonality'. Nineteenth-Century Music, Vol. 29, No. 3 (2006), pp. 240-60.

Mitchell, Jerome. The Walter Scott Operas. Tuscaloosa: University of Alabama Press, 1977.

Monelle, Raymond. 'Scottish Music, Real and Spurious' in Music and Nationalism in $20^{\text {th }}$-Century Great Britain and Finland. Hamburg: Van Bockel, 1997.

Nagal, Julie Jaffee. 'Psychoanalytical and Musical Perspectives on Shame in Donizetti's Lucia di Lammermoor'. Journal of the American Psychoanalytic Association, Vol. 56, No. 2 (2008), pp. 552-63.

Nicolaisen, Jay. Italian Opera in Transition: 1871-1893. Ann Arbor: UMI Research Press, 1980.

Nicolodi, Fiamma. 'Italian Opera'. In The Cambridge Companion to Grand Opera, edited by David Charlton. Cambridge: Cambridge University Press, 2003, pp. 383-402.

Okun, Henry. 'Ossian in Painting'. Journal of the Warburg and Courtauld Institutes, Vol. 30 (1967), pp. 327-56.

Osborne, Charles. The Complete Operas of Verdi: An Interpretive Study of the Librettos and Music and their Relation to the Composer's Life. New York: Da Capo Press, 1969.

Osborne, Richard. 'La Donna del lago'. In The New Grove Dictionary of Opera. In Oxford Music Online, http://www.oxfordmusiconline.com. (25 April 2009).

Parker, Roger. 'Elisabeth's Last Act'. In Siren Songs: Representations of Gender and Sexuality in Opera, edited by Mary Ann Smart. Princeton: Princeton University Press, 2000, pp.93-117.

- 'Attila'. In The New Grove Dictionary of Opera. Oxford Music Online. www.oxfordmusiconline.com. (26 August 2010). 
Paula, Georg and David Blayney Brown. 'Füssli'. In Grove Art Online, Oxford Art Online, http://www.oxfordartonline.com. (20 June 2010).

Petrobelli, Pierluigi. 'Verdi's Musical Thought: And Example from Macbeth'. In Music in the Theatre: Essays on Verdi and Other Composers, translated by Roger Parker. Princeton: Princeton University Press, 1994.

Pinzauti, Leonardo. 'Verdi's Macbeth and the Florentine Critics'. In Verdi's 'Macbeth': A Sourcebook, edited by David Rosen and Andrew Porter. Cambridge: Cambridge University Press, 1984.

Poriss, Hilary. 'A Madwoman's Choice: Aria Substitution in Lucia di Lammermoor. Cambridge Opera Journal, Vol. 13, No. 1 (March 2001), pp. 1-28.

Changing the Score: Arias, Prima Donnas, and the Authority of Performance. Oxford: Oxford University Press, 2009.

- $\quad$ 'Introduction: Italian Opera's Fashions and Legacies'. In Fashion and Legacies of Nineteenth-Century Italian Opera, edited by Roberta Montemorra martin and Hilary Poriss. Cambridge: Cambridge University Press, 2009, p. 1-8.

Porter, James. 'Ossian'. In Grove Music Dictionary Online. Oxford Music Online. www.oxfordmusiconline.com. (19 May 2008).

Pugliese, Romana Margherita. 'The Origins of Lucia di Lammermoor's Cadenza'. Cambridge opera Journal, Vol. 16, No. 1, (2004), pp. 23-42.

Punter, Davis. 'Scottish and Irish Gothic'. In The Cambridge Companion to Gothic Fiction, edited by Jerrold E. Hogle. Cambridge: Cambridge University Press, 2001, pp. 105-24.

Riall, Lucy. The Italian Risorgimento: State, Society, and National Unification. London and New York: Routledge, 1994.

Roselli, John. The Opera Industry in Italy from Cimarosa to Verdi: The Role of the Impresario. Cambridge: Cambridge University Press, 1984.

- $\quad$ 'Music and Nationalism in Italy'. In Musical Constructions of Nationalism, edited by Harry White and Michael Murphy. Cork: Cork University Press, 2001.

Rosen, David and Andrew Porter. Verdi's 'Macbeth': A Sourcebook. Cambridge: Cambridge University Press, 1984.

Rosenthal, Michael. 'Constable, John'. Grove Art Online. Oxford Art Online. http://www.oxfordartonline.com. (12 February 2010).

Rubin, J. H. 'Realism'. In Grove Art Online. Oxford Art Online. 
http://oxfordartonline.com/subscriber/article/grove/art/T070996. (12 February 2010).

Schlegel, Augustus William. Course of Lectures on Dramatic Art and Literature.

Translated by John Black, London: 1846. New York: AMS, 1973.

Schmidgal, Gary. Literature as Opera. Oxford: Oxford University Press, 1977.

- $\quad$ Shakespeare and Opera. Oxford: Oxford University Press, 1990.

Schmitt, Cannon. Alien Nation: Nineteenth-Century Gothic Fictions and English Nationality. Philadelphia: University of Pennsylvania Press, 1997.

Scholes, Robert. 'The Blood of an Innocent Woman: Bel Canto and the Gothic'. A Yearbook of Interdisciplinary Studies in the Fine Arts, Vol. 1 (1989), pp. 22537.

Scott, Sir Walter. The Bride of Lammermoor, edited by J. H. Alexander. London: Penguin, 2000.

- $\quad$ The Journal of Sir Walter Scott, edited by John Guthrie Tait. Edinburgh: Oliver and Boyd, 1950.

Senici, Emmanuele. Landscape and Gender in Italian Opera: The Alpine Virgin from Bellini to Puccini. Cambridge: Cambridge University Press, 2005.

Shakespeare, William. The Oxford Shakespeare: The Complete Works, 2ed. Edited by Gary Taylor and Stanley Wells. Oxford: Oxford University Press, 2005.

Showalter, Elaine: The Female Malady: Women, Madness and English Culture 18301980. London: Virago, 1987.

Smart, Mary Ann. Dalla Tombe Uscita: Representations of Madness in NineteenthCentury Italian Opera. Ph. D., Cornell University, 1994.

- $\quad$ 'The Silencing of Lucia'. Cambridge Opera Journal, Vol. 4, No. 2 (July 1992), pp. 119-41.

- $\quad$ 'Introduction'. In Siren Songs: Representations of Gender and Sexuality in Opera, edited by Mary Ann Smart. Princeton: Princeton University Press, 2000, pp. 3-16.

- $\quad$ 'Ulterior Motives: Verdi's Recurring Themes Revisited'. In Siren Songs: Representations of Gender and Sexuality in Opera, edited by Mary Ann Smart. Princeton: Princeton University Press, 2000, pp.135-59.

Mimomania: Music and Gesture in Nineteenth-Century Opera. Berkeley: University of California Press, 2004. 
Smith, Christopher. 'Ossian in Music'. In The Reception of Ossian in Europe, edited by Howard Gaskell. London: Thoemmes Continuum, 2004, pp. 375-92.

Staffieri, Gloria. 'Da Robert le diable a Macbeth: Influsso di Meyerbeer sulla produzione verdiana degli anni Quaranta'. Studi Verdiani, Vol. 13 (1998), pp. 13 -44 .

- 'Grand Opéra in Preunified Italy: Metamorphoses of a Political Genre', The Opera Quarterly, Vol. 25, No. 3-4 (2009), pp. 203-229.

Sweeny-Turner, Steve. 'The Political Parlour: Identity and Ideology in Scottish National Song'. In Musical Constructions of Nationalism, edited by Harry White and Michael Murphy. Cork: Cork University Press, 2001, pp. 212-38.

Tambling, Jeremy. 'Scott's 'Heyday' in Opera'. In Reception of Sir Walter Scott in Europe, edited by Murray Pittock. London: Continuum, 2007, pp. 285-92.

Todd, R. Larry. Mendelssohn: A Life in Music. Oxford: Oxford University Press, 2003.

Tomlinson, Gary. 'Italian Romanticism and Italian Opera: An Essay in their Affinities'. Nineteenth-Century Music, Vol. 10, No. 1 (1986), pp. 43-60. Metaphysical Song: An Essay on Opera. Princeton: Princeton University Press, 1999.

Verdi, Giuseppe. Macbeth: The Works of Giuseppe Verdi, I:10, edited by David Lawton. Chicago: Chicago University Press, 2003.

Viale Ferrero, Mercedes. 'Stage and Set'. In Opera on Stage, edited by Lorenzo Bianco and Giorgio Pestelli and translated by Kate Singleton. Chicago: Chicago University Press, 2002, pp. 1-124.

- and Francesca Franchi. 'Costume Designs by Alessandro Sanquirico and Others for Ballets Performed at the Teatro alla Scala, Milan 1820-24'. The Journal of the Society for Dance Research, Vol. 2, No. 2 (Summer 1984), pp. 24-40.

Walpole, Horace. The Castle of Otranto, edited by Paul Negri. New York: Dover, 1966.

Weaver, William. 'The Shakespeare Verdi Knew'. In Verdi's 'Macbeth': A Sourcebook, edited by David Rosen and Andrew Porter. Cambridge: Cambridge University Press, 1984.

Weinstock, Herbert. Donizetti and the World of Opera in Italy, Paris and Vienna in the First Half of the Nineteenth Century. London: Methuen, 1963.

White, Nicholas. 'Fictions and Librettos'. In The Cambridge Companion to Grand Opera, edited by David Charlton. Cambridge: Cambridge University Press, 2003, pp. 43-57. 
Williams, Anne. Art of Darkness: A Poetics of Gothic. Chicago: Chicago University Press, 1995.

- $\quad$ 'Ghostly Voices: "Gothic Opera" and the Failure of Gounods La Nonne Sanglante'. In Operatic Migrations: Transforming Works and Crossing Boundaries, edited by Roberta Montemorra Marvin and Downing A. Thomas. Aldershot: Ashgate, 2006, pp. 125-43.

Williams, Simon. 'The Spectacle of the Past in Grand Opera'. In The Cambridge Companion to Grand Opera, edited by David Charlton. Cambridge: Cambridge University Press, 2003, pp. 58-75.

Willier, Stephan Ace. Early Nineteenth-Century Opera and the Impact of the Gothic. Ph. D., University of Illinois, 1987.

'Madness, the Gothic and Bellini's Il Piratai'. The Opera Quarterly, Vol. 6, No. 4 (1989), pp. 7-33.

Wright, Angela. Gothic Fiction. New York: Palgrave MacMillan, 2007.

Zingel, Hans Joachim. Harp Music in the Nineteenth Century. Translated by Mark Palkovic. Bloomington: Indiana University Press, 1992. 